\author{
Szegedi Tudományegyetem \\ Bölcsészettudományi Kar \\ Irodalomtudományi Doktori Iskola
}

\title{
Az arctalanítás poétikája
}

A tropizmus szereplőfelfogása Nathalie Sarraute életmüvében

Doktori értekezés

Gombkötőné Lombár Izabella

2020

Témavezető: dr. habil. Gyimesi Tímea 


\section{NYILATKOZAT}

Kijelentem, hogy ez az értekezés mind egészében (koncepciójában), mind részleteiben (a szöveg szintjén) saját művem. A felhasznált forrásokra - nyomtatott, illetve elektronikus szakirodalomra - a Szegedi Tudományegyetem Bölcsészettudományi Karának Irodalomtudományi Doktori Iskolája által megadott doktori értekezési elöírásoknak megfelelően hivatkozom.

Szeged, 2020. január 15.

Gombkötőné Lombár Izabella 
Hogy mondtuk elébb? A Lét lényege valami „,negatívum” - valóban, mikor az Ószövetség különbözö szerzöi a maguk ,Jehova”-figuráját (vagy figurátlanságát?) megszerkesztették, ez a figura (vagy mint mondom: figurátlanság) tulajdonképpen szintén a ,névtelen titkot” jelképezi, azt a gondolatot, hogy , a világ alján van valami borzalmasan jelentös, egyetlen és végtelen dolog, de ez az egyetlen fontos és ez az egyetlen jelentös = érthetetlen, sőt talán értelmetlen". Érdekes ez a két véglet: ez a ,Jehova”-dolog egyrészt maga a világ alján leskelödö potens Nihil, a semmi - másrészt meg az Ábrahámok meg Jákobok nagyon is konkrét pásztori tartozéka, olyan, mint egy vajköpülödézsa vagy szalonnapiritásra is alkalmas piszkavas.

Szentkuthy Miklós PENDRAGON ÉS XIII. APOLLÓ Részlet 


\section{Tartalom}

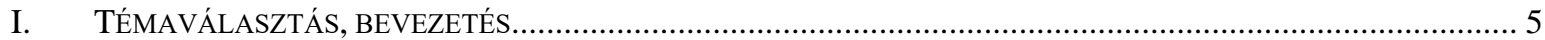

II. NATHALIE SARRAUTE - IRODALMI KONTEXTUS, FRANCIA ÉS MAGYAR RECEPCIÓ....................................8

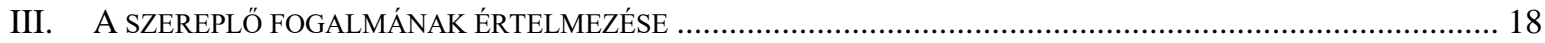

III.1. A klasszikus arisztotelészi poétika szereplöértelmezésének válsága-az 1920-as, 30-as évek

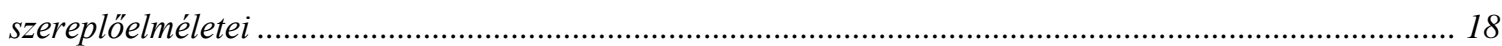

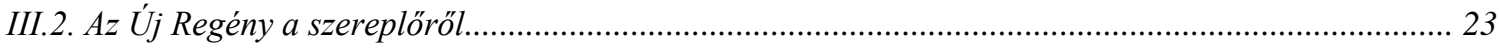

III.2.1. Alain Robbe-Grillet elméleti megközelítése ................................................... 23

III.2.2. Nathalie Sarraute a szereplőről ................................................................ 25

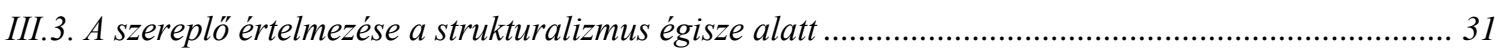

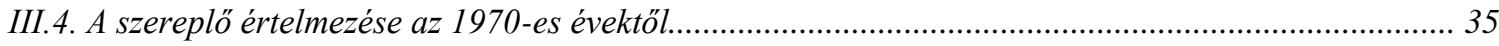

III.5. Az Új Regény és Nathalie Sarraute szereplöelmélete a korszak elméleteinek viszonylatában ............ 38

IV. NATHALIE SARRAUTE STÍluSFOGALMA. A SZEREPLÖ STILISZTIKÁJA..................................................42

IV.1. A stílusfogalom modern és posztmodern kori jelentösége ........................................................ 44

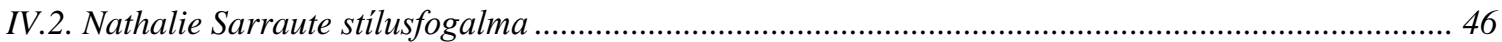

IV.3. Nathalie Sarraute és Gilles Deleuze stílusfogalmának egymásra vetitése - a dadogás mint központi

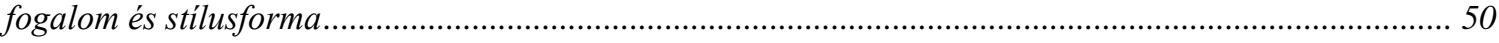

IV.4. A stílus elsödlegességének és a szereplö dekonstrukciójának összefüggése .................................... 57

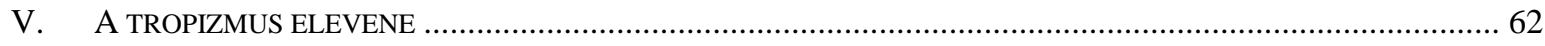

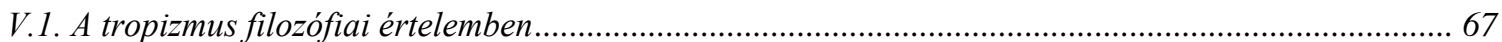

V.2. A tropizmusok hátterében megbújó szereplöfogalom ..................................................................... 75

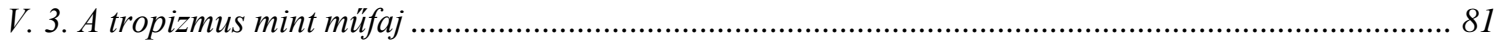

V. 4. Nathalie Sarraute tropizmusai - a szereplö feloldódása fikció és dikció között ............................... 85

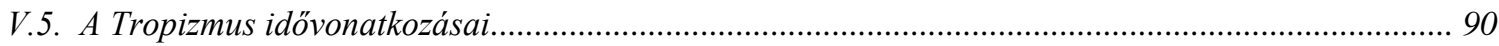

VI. NATHALIE SARRAUTE TOVÁBBI EPIKUS MÜVEINEK SZEREPLÖI _.................................................... 102

VI.1. Név nélküli szereplö - Portrait d'un inconnu ............................................................................ 106

VI.2. A szereplö-alak magánya - Planetárium ............................................................................ 112

VI.3. A szereplök tárgyak vagy elvont dolgok - Les Fruits d'or ....................................................... 117

VII.4. Az önéletírás föszereplöjének dekonstrukciója, az én feloldódása a szöveg makrostrukturális szintü

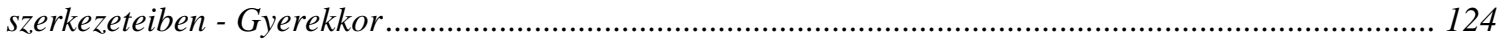

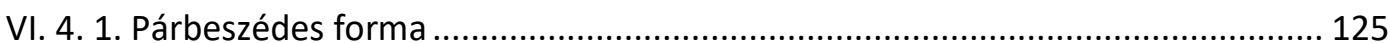

VI.4.2. Időszerkezet, időstruktúrák, igeidők és a két énelbeszélő szövegszerű

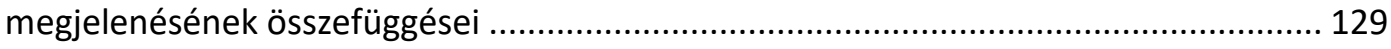

VI.4.3. A Gyerekkor szereplőinek szavai mint idézés és párbeszéd ............................ 134

VI.4.4. Központozás a Gyerekkor énelbeszélőjének szövegében ............................... 138

VI.5. Molekuláris szereplök - Tu ne t'aimes pas ................................................................................ 145

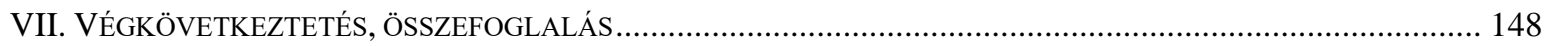

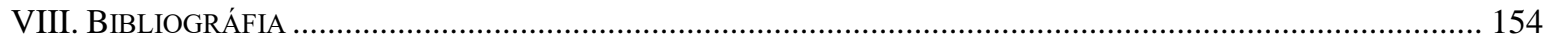

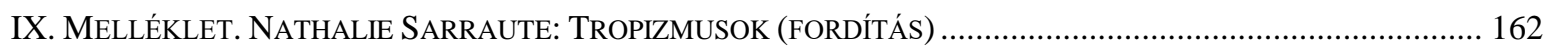




\section{l. Témaválasztás, bevezetés}

Értekezésem célja, hogy egy, a magyar recepcióban és irodalomtudományban talán méltatlanul elhanyagolt szerző, Nathalie Sarraute életmúvének megvilágítsam azt a leginkább jellegzetes sajátosságát, hogy tropizmusainak hátterében a klasszikus narratív technikák lebontásában a szereplő feloldódása kapja a legnagyobb hangsúlyt. Dolgozatom elején az említett ismeretlenség okán feltárom a Sarraute-életmü francia és magyar recepciójának jellegét. A francia recepció rendkívül széttartó és heterogén voltára kívánok rámutatni, ugyanakkor megemlítem a magyar Sarraute-szövegeket érintő fordításirodalom és tudományos fogadtatás hiányosságait. Dolgozatom bevezetőjében utalok Sarraute írásművészetének és az Új Regény elméletének azon sajátosságaira, amelyek kapcsolatban állnak dolgozatom témájával, ugyanakkor nem kívánok teljes irodalomtörténeti képet adni az Új Regényről vagy Nathalie Sarraute, valamint az Új Regény kapcsolatáról.

Fontosnak tartom, hogy a III. fejezetben a sarraute-i szereplö-alak kialakulásának háttereként végigkövessem a karakter- és jellemértelmezés 20. századi változásait, elsősorban a francia teoretikus hagyományban. Később ezt kapcsolom az Új Regény által megfogalmazott elméleti alapvetésekhez. Ebben a részben a történeti áttekintés mellett rávilágítok: a klasszikus regényértelmezéshez kapcsolódó tradíció egyes elemeinek (történet, idő, szereplö) lebontásában a kulcs a szubjektum átértelmeződése, és ezen keresztül a szereplő dekonstrukciója. Ebben a részben feltérképezem, hogy a szereplöértelmezések a XX. század folyamán alapvetően három irányban indultak: az elkötelezett irodalom továbbra is a karakterek társadalmi beágyazottságát, etikai szempontú értelmezést lehetővé tevő jellemét vizsgálja, az abszurdot megvalósító regényvilágok célja, hogy megmutassák, hogyan mozognak a szereplők világunk filozófiailag ellehetetlenülő értelmezési keretében, míg az Új Regény, s így Nathalie Sarraute számára is, a szereplő kizárólag nyelvi eszközökkel, stílusszinten való megragadása filozófiai szempontból visszamutat a szubjektum dekonstrukciójára, írástechnikailag pedig elöremutat a szereplö, és rajta keresztül a cselekmény, a hely, az idő regényen belüli tudatos töredezettségére.

Mivel az új, a karaktertől elszakadó szereplő-alak nem értékrendjében, ideológiáiban, jellemében megragadható, ezért az IV. fejezetben arra fókuszál az értekezés, hogy az ábrázolást hogyan váltja fel a stílus, a nyelvhasználat elsődlegessége. A stílusfogalom 
sarraute-i megfogalmazása alapvető összefüggéseket mutat a tropizmusok keletkezéstörténetével, a tropizmus pedig az írónő szövegeinek ,mindenese”: a szereplő, a müfaj, a stílus, a nyelvhasználat. A Sarraute-stílusfogalom külső fogalmi megragadása céljából taglalom a stílus és a nyelvhasználat elsődlegességének jelentőségét, illetve a deleuze-i stílusfogalom azon sajátosságait, amelyek összefüggésbe hozhatók a Sarrauteéletművel. Azt kívánom bizonyítani, hogy az Új Regény által fontosnak tartott, a klasszikus narratívákat leépítő dekonstrukciós folyamatot a Sarraute-életmü megvalósítja, de mindvégig a szereplő feloldódásán, a szubjektum széttöredezettségén keresztül közelíti mind a cselekményvezetés, mind az idő linearitásának tudatos elfolyatását. Ahogyan Micheline Tison-Braun ${ }^{1}$ megjegyzi, az Új Regényhez kapcsolódó műveket, köztük Nathalie Sarraute írásait is a „stilisztikai és írástechnikai akrobatika”2 jellemzi. Ezek a szépirodalmi alkotások, bár a formalizmustól távol állnak, mégis tartalmilag megközelíthetetlenek, üzenetük homályban marad, s csak a stílus felől kaphat valamelyest fogódzót az értelmezői nézőpont. ${ }^{3}$

Nathalie Sarraute életművének elméleti vetülete felöl is közelítem a szereplőfogalmat amellett, hogy az írónő esszéit immanens módon vizsgálom. A szereplő fogalmának alakulástörténetében szemlélem Sarraute elméleti munkáinak és epikus müveinek összefüggésrendszerét. Így találja meg a helyét a jelen dolgozatban az elméleti és a szépirodalmi szövegek világa, amelyeknek egymásra vetítése a cél. Ezzel együtt nem témája a dolgozatnak, hogy bemutassuk, a sarraute-i gyakorlat, tehát a szépirodalmi müvek megvalósítása megfelel-e az elméletnek, azaz az esszéiben megfogalmazottaknak. Sarraute tanulmányai és előadásai, mint már említettem, föképpen azért születtek, mert élete korai szakaszában sikertelen szerzőnek számított, és az írónő önigazolást keresett. Nem ars poeticát írt vagy írói szemináriumi kézikönyveket. Esszéi és előadásai ugyanakkor terminológiát és keretet adnak szépirodalmi szövegeinek értelmezéséhez.

A szereplő klasszikus karakterjellegének lebontása és stilisztikai felépíthetősége kapcsán Gilles Deleuze arctalanítás-fogalma ${ }^{4}$ is bevezetésre kerül. Ez a terminus és az általa megmozgatható elméleti háttér értelmezést elösegítő keretet ad Nathalie Sarraute esszéiben és írói gyakorlatában megjelenő törekvéseinek, amelyek a karakterekben individuálódó személyszerü szereplőktől való elfordulást realizálják, akár irodalmi eszközökkel, akár teoretikusan. Ha nem jelenik meg a klasszikus narratívának a valóságot reprezentáló

\footnotetext{
${ }^{1}$ Micheline Tison-Braun (1971). Nathalie Sarraute ou la Recherche de l'authenticité, Gallimard, p. 9.

${ }^{2}$ U.o. ,acrobaties techniques et verbales"

${ }^{3}$ U.o. „forme vaine”, „énigme à résoudre”, Nathalie Sarraute: „éloignée du formalisme”

${ }^{4}$ visage, visagéité, perte de visage - arc, arcadás, arctalanítás in Deleuze-Guattari (1980). Mille plateaux 5. fejezet
} 
szereplője, akkor a Sarraute regényeiben kitapintható „valakit” annak szövegszerüségében kell tudnunk értelmezni. Ezért a továbbiakban a szereplö-alak nyelvi megformálását jelenlétszerüségében, stilisztikai felépítettségében tartom lehetségesnek. Ennek háttereként az V. fejezetben felhívom a figyelmet a stilisztikai vizsgálatok jelentőségére, és ezzel együtt a stílusfogalom Sarraute-nál megjelenő fő csapásirányaira. Mivel az arctalanítás gesztusa kapcsán már bevezetésre került a deleuze-i fogalomrendszer, ezért tartom fontosnak, hogy Sarraute és Deleuze stílusfogalmának egymásra vetítésével további adalékot adjak a Sarrauteéletmü értelmezésének kitágításához. Itt elsősorban a dadogás stílusfogalmának, a kettőközöttiséget különféle stílusformákkal megvalósító szövegépítkezésnek és szereplődekonstrukciónak a változatait a gyakorlatban vizsgálom úgy, hogy körüljárom a legalapvetőbb sarraute-i fogalmat, a tropizmust, annak elméletét és gyakorlatát.

A tropizmusra fókuszáló V. fejezet gyújtópontjában az arctalanítás és a stílus mellett két további deleuze-i fogalom segítségével reflektálok a sarraute-i elméletre és írói gyakorlatra. Az egyik a haptikus, azaz tapintó látás, közellátás, melynek teorémáival támogatom kívülröl a sarraute-i immanens értelmezési irányokat. Egyértelművé kívánom tenni ennek segítségével, hogy a tropizmusok sem nem epikusan, elbeszélésszerüen, sem nem költőien, azaz metaforikusan építkező szövegek, hanem kettőközöttiségükben ragadhatóak meg, elsősorban szinesztéziákból, metonímiákból, mellérendelésekből, felsorolásokból sejlik fel bennük a megjelenő beszédhelyzet vagy érzetköteg. Ennek a folyamatnak a fogalmi megragadásában segít a deleuze-i haptikus látásfogalom. A másik vizsgált vonatkozás a tropizmusok tekintetében az időhasználat különlegessége, melyhez felhasználom Deleuze Aion és Chronos időfogalmát, illetve a Sarraute-szövegekben tapintható stilizált idő kibontását, értelmezését. A tropizmus-fogalom többirányú körüljárásának célja, hogy megmutassam: a szereplő újfajta koncepciója a klasszikus narrativitás egyéb vetületeinek módosulásával is együtt jár. A tropizmusokra vetülő egyes nézőpontokat egy-egy szépirodalmi szöveg, tropizmus müelemzésével zárom. Minden esetben arra koncentrálok az elemzésekben, hogy az adott tropizmus-szekvencia hogyan dekonstruálja a szereplőt, hogyan lehetetlenül el a karakter, hogyan válik tropizmus-foglalattá.

Az elmélet és a szépirodalmi megvalósítás diszkrét egymásra vetítése kapcsán a dolgozat utolsó harmadában a szereplő megjelenésének változataira fókuszálok. Megvizsgálom, hogy milyen stílusformákban jelentkezett az életmü egyes szakaszai során a szerző általi szövegszerü arcadás és arctalanítás anélkül, hogy valódi, mélyreható változáson ment volna át a tropizmusok világához képest. Itt a változatokat nem fejlődésükben kívánom 
szemlélni, hanem éppen ellenkezőleg, lényegi azonosságukban, de stílusbeli megvalósulásaik esetleges eltéréseiben. Megfigyelem a vissza-visszatérő gesztusokat (személyes névmás mint szereplö, mellérendelések és nem hierarchiák), ugyanakkor felhívom a figyelmet a meglepő fordulatokra vagy újdonságokra is (párbeszédes kettős elbeszélés a Gyerekkorban, és az ahhoz kapcsolódó klasszikus elbeszélés-morzsák). Arra kívánok ebben a részben rávilágítani, hogy bár a szerző alapvető hozzáállása a szereplő megjelenítéséhez az arctalanítás szándéka, amin a személyesség és a jelentésesség ellehetetlenítését értem, ugyanakkor szövegszerüségében mindez változatokban jelentkezik. Ezeknek a változatoknak a stilisztikailag pontos megragadására törekszem.

Dolgozatom felépítésében hangsúlyos szerepe van az eredeti művek elemzésének, és ezzel összefüggésben még egyes, le nem fordított alkotások magyarul való bemutatásának. Azokat a szövegrészleteket, amelyeknek a fordítása magyarul megtalálható, a fordító nevének feltüntetésével lábjegyzetben jelölöm minden esetben. Amikor azonban nem született fordítás az adott, elemezni kívánt szövegrészhez, akkor az általam fordított szöveg jelenik meg a dolgozatban, az eredeti pedig idézőjelben lábjegyzetben minden esetben szerepel.

\section{Nathalie Sarraute - Irodalmi kontextus, francia és magyar recepció}

Ha még a XX. században lennénk, azzal a hangzatos mondattal kezdhetnénk a fejezetet, hogy Nathalie Sarraute a századdal együtt született ${ }^{5}$. És valóban, a XX. század számos irodalmi irányzat, politikai változás és történelmi esemény katalizátora volt, illetve fordítva, az új irányzatok és politikai-történelmi jelenségek formálták a századot. Mindenesetre az a társadalmi kontextus, amely a XIX. századot jellemezte, már biztosan a múlté lett, és ilyenformán az írók is új tartalmakat és formákat kerestek az önkifejezés számára. Nathalie Sarraute a 30-as évektől folyamatosan, egészen haláláig „munkaszerüen”

\footnotetext{
5 1900-ben született Moszkvában, Natasa Csernyák néven, zsidó értelmiségi családban. Apja vegyészmérnök kutató, tudós. Anyja, Paulina Csatunovszki, álnéven novellákat és regényeket publikál. 1902-ben elválnak a szülei, ennek élménye nagy mértékben áthatja Gyermekkor címü regényét. Natasa először az édesanyjával él, akivel elhagyják Oroszországot és Párizsba költöznek, azonban az évente egyhónapos láthatások alkalmával szoros kapcsolatot tart fenn az édesapjával. Később visszaköltözik Oroszországba az időközben újra férjhez ment édesanyjával, ezúttal Szentpétervárra. Édesapjának politikai okokból nem sokkal később emigrálnia kell, és 1907-ben Franciaországba költözik, ahol festéküzemet alapít. Natasa ekkor költözik újra megnősült apához, majd megszületnek féltestvérei, Hélène és Jacques. Az 1910-es, 20-as években elmélyed tanulmányaiban: angol szakon végez a Sorbonne-on, majd Oxfordban müvészettörténeti ismereteit mélyíti el, hogy a berlini szociológusi félév után Párizsban jogra iratkozzon. Férje Raymond Sarraute jogász, három lányuk lesz, közülük a legismertebb Claude Sarraute újságíró. 1926 és 41 között ügyvédként dolgozik. 1941-ben zsidó származása miatt bujkálni kényszerül.
} 
alkotott, minden nap tudatosan több órát írásnak szentelve, ha lehetséges, egy, az otthonától eltérő, semleges helyen, például kávézóban. ${ }^{6}$

Első szövegei, a költői indíttatású Tropizmusok számára már 1938-tól kiadót keres, de mind a Gallimard, mind a Grasset visszautasítja, míg végül 1939-ben Robert Danoël, aki már Queneau és Céline kiadója is volt, elfogadja a kéziratot és még abban az évben megjelenteti ${ }^{7}$. Később, a II. világháború borzalmaitól menekülve, a világtól elzárva írja meg Portrait d'un inconnu címủ mủvét, melyhez Jean-Paul Sartre ír előszót. A Les Fruits d'or címủ regényéért 1964-ben Nemzetközi Irodalmi Díjat kap. ${ }^{8}$ Világviszonylatban talán leghíresebb regénye az önéletrajzi Gyerekkor.

Feltehető a kérdés, hogy a szereplő-alak semlegesítésére, stilizálására való, már a Tropizmusokban tetten érhető törekvés hátterében nem áll-e Nathalie Sarraute kettősnyelvüsége? Cristina Zanoaga-Rastoll ${ }^{9}$ szintén rákérdez erre egyik tanulmányában, amely alapján az az értelmezés is lehetséges, hogy igen. Nathalie Sarraute orosz anyanyelvüsége ellenére következetesen állította, hogy a francia az „első nyelve” és elsődleges volt számára egész életén át az is, hogy egyre mélyebbre hatoljon rejtelmeibe: „A francia számomra nem felvett nyelv, hanem az első nyelvem, amelyen beszélni kezdtem kétés ötéves korom között, amikor Párizsban éltem. (...) Éppen oroszul van enyhe akcentusom és ezt mindig is sajnáltam. Soha nem tudtam ezt igazán korrigálni."10 Nathalie Sarraute, különböző életkorszakaiban eltérö nyelvekkel került kapcsolatba: az orosz a szülei nyelve volt, de mivel mindketten Genfben tanultak, és később különböző időpontokban éltek Franciaországban, jól beszélték a franciát; az írónő még németül is tudott: a Gyerekkorban

\footnotetext{
${ }^{6}$ Nathalie Sarraute megjelent föbb művei: Tropismes (1939), Portrait d'un inconnu (1948) [Egy ismeretlen arcképe], Martereau (1953), L’Ėre du soupçon (1956) [A gyanakvás korszaka], Le Planétarium (1959) [A planetárium], Les Fruits d'or (1963) [Arany gyümölcsök], Le Silence [A csend], Le Mensonge [A hazugság] (1967), Entre la vie et la mort (1968) [Élet és halál között], Isma ,Ce qui s'appelle rien (1970) [Amit semminek hívnak], Vous les entendez ? (1972) [Halljátok őket?], "Disent les imbéciles" (1976) [Mondják a bolondok], Théâtre contenant Elle est là (E.O.) [Ö itt van], Le Mensonge, Isma, C'est beau [Szép] (1978), L'Usage de la parole (1980) [A szavak használata], Pour un oui ou pour un non (1982) [Egy igenért és egy nemért], Enfance (1983) [Gyerekkor], Paul Valéry et l'enfant d'éléphant [Paul Valéry és az elefántbébi], Flaubert le précurseur (1986) [Flaubert mint előkép], Tu ne t'aimes pas (1989) [Nem szereted magad], Ici (1995) [Itt], Euvres complètes [La Pléiade] (1996), Ouvrez (1997) [Nyissátok ki], CEuvres complètes [La Pléiade - az Ouvrez-val együtt] (2011), Lettres d'Amérique (2017) [Levelek Amerikából]

${ }^{7}$ Sarraute, CEuvres complète, p. 1718.

${ }^{8} \mathrm{http}: / /$ auteurs.contemporaininfo/doku.php/auteurs/nathalie_sarraute

9 Cristina Zanoaga-Rastoll (2016), Les langues des tropismes chez Nathalie Sarraute Elérhetö: https://journals.openedition.org/carnets/1062, Letöltés ideje: 2019. 11. 25.

10 Pivot, Bernard (1972). "Nathalie Sarraute a réponse à tous", Le Figaro littéraire, $\mathrm{n}^{\circ}$ 1342, pp. 1-13. „Le français n'a pas été pour moi une langue d'adoption, mais bien ma première langue, celle dans laquelle j'ai commencé à parler quand entre 2 et 5 ans j'ai vécu à Paris. (...) C'est en russe que j'ai - et cela m'a toujours désolée - un léger accent. Je n'ai jamais pu m'en corriger. (...)"
} 
említést tesz svájci-német nevelőnőjéről, de később Berlinben is tanul. Angol szakos bölcsészhallgatóként pedig igen jól ismerte Shakespeare nyelvét és töltött is időt Oxfordban.

A francia számára a szociális nyelv, az iskola, az írás, az olvasás, az otthoni etikett nyelve. Értelmezésem szerint egyfajta „menekülő nyelv” is, amelybe a szétszakított szülőpár nyelvéből mintegy a szabad, független szubjektum felépítése felé irányulhatott a gyermeki elme. Mondjuk, hogy ahány nyelvet beszélünk, annyi ember lehetünk. Az apa és az anya az anyanyelv segítségével mintegy „felépíti” gyermekét. Ha feltesszük, hogy ez a folyamat sérülhetett Sarraute gyerekkorában és a gyermek énje rádöbbent: magát kell felépítenie, akkor a szubjektumnak egy másik nyelvből való „felépítése” lehetséges megoldásnak tűnik. Valójában egész későbbi életművén át, és ez dolgozatom kiemelt témája, a szubjektum nyelvi-stilisztikai felépíthetőségével kísérletezik.

Saját bevallása szerint „érzékeny” az orosz nyelv szépségére, de intellektuálisan is hat rá, hiszen említi, hogy egyrészt eredeti nyelven olvassa a klasszikusokat, például Dosztojevszkijt és Csehovot, valamint Franciaországban élő értelmiségiként levelezésben áll olyan orosz entellektüelekkel, mint Anna Ahmatova11. Legtöbb szövegében, a Gyerekkort kivéve, semmilyen orosz nyelvi vagy kulturális utalás nem fedezhető fel, és ez is utal arra, hogy a szereplö-alakot nem annak társadalmi, nyelvi, jellembeli vetületeivel alkotja meg, hanem az „első nyelvből”, a francia nyelvből és stílusból.

Erre Cristina Zanoaga-Rastoll tanulmánya szintén rámutat: Nathalie Sarraute életművének középpontjában nem a személyes, nyelvi, kulturális, nemzeti identitás, hanem az „,irodalmi-nyelvi identitás” keresése áll ${ }^{12}$. Az írónő ezt a nyelvi-stilisztikai eszközökkel felépülő semleges szubjektumot egy orosz szó segítségével ragadja meg: „Az emberi létező felfogásom szerint semleges. Van erre egy jó orosz szó: a „cselovjek”"13: emberi lény, férfi vagy nő, mindegy is a kora, a neme. Franciául az „emberi létező” kifejezés számomra nevetséges." ${ }^{14}$ Különös kettősség figyelhető meg a fenti idézetben: az orosz, Sarraute által semlegesnek értelmezett „személy” szó hangsúlyozása és a francia fogalommal szembeni előtérbe helyezése ellentétben áll a személy, a szereplő-alak francia nyelv és stílus általi felépíthetőségének gyakorlatával. Kétségkívül, ahogyan a fentiekben már utaltam rá,

\footnotetext{
11 U.o.

12 Zanoaga-Rastoll (2016.) „occulter son identité personnelle pour revendiquer en revanche une identité littéraire et linguistique"

13 человек (m)

${ }^{14}$ Benmussa, Simone (1999). Entretiens avec Nathalie Sarraute. La Renaissance du livre. p. 149. „C'est l'être humain pour moi, le neutre. Il y a un mot pour ça en russe c'est tcheloviek (...), l'être humain, homme ou femme, peu importe l'âge, peu importe le sexe. En français 'être humain' est ridicule”
} 
Zanoaga-Rastoll meg is jegyzi: a Gyerekkor címü önéletrajzi írás tartalmazza a legtöbb orosz nyelvi utalást Sarraute életművében. Ezt azzal magyarázza, hogy az orosz anyanyelv Sarraute számára az érzelmi binaritást jelenti: a pozitív és negatív pólust, míg az „első nyelvként” elsajátított francia számára mindig is a megfelelő szóválasztás iránti érzékenységnek, a legapróbb jelentéskülönbségek iránti fogékonyságnak, a szavak konnotatív erejének, a nyelvhasználat szépirodalmi eszközökkel való „átlelkesítésének”15 semleges, ám a szubjektum szempontjából megtartó, „megmentő” terepe.

Egyszóval az írónő származása látszólag nem nyomja rá a bélyegét írásművészetére úgy, mint nemzeti identitás vagy az azzal kapcsolatos erkölcsi-politikai dilemmák. Ugyanakkor a francia nyelv tudatos választását, a stílusérzékenység gyakorlatát, valamint az érzelmek, a történet, a hősök kiiktatását már annál inkább motiválják a szerző gyermekkori, s elsősorban az orosz nyelvhez, a szülőkhöz füződő megélései.

Ha a Sarraute-életművet irodalomtörténeti irányzathoz kívánjuk kapcsolni, akkor az Új Regényhez való tartozását kell megemlítenünk. Emile Henriot-nak, a Le Monde újságírójának tulajdonítják az „Új Regény” elnevezést. Sarraute Tropizmusairól és Alain Robbe-Grillet Kukkolójáról írt recenziót a lapban 1957. május 22-én ${ }^{16}$, és akkor használta első ízben az írók egy csoportjára alkalmazott kifejezést. Az Új Regény szerzői mindnyájan arra törekszenek, hogy lebontsák a hagyományos regény építőelemeinek kötelező megjelenését: a szereplő, a kronologikus időrendiség, a valószerüség klasszikus formai megoldásait igyekeznek átformálni. Claude Lévi-Strauss az új regényírókra a bricoleur ${ }^{17}$ (barkácsoló) kifejezést használja ${ }^{18}$. A Le Figaro Littéraire 1956. július 28-i számában François Mauriac azt veti Alain Robbe-Grillet szemére, hogy „a felszínen megjelenő technikák alatt a mélység gyülölete rejtőzik.”19 Válaszában Robbe-Grillet kijelenti, hogy a dolgok mögötti mélyréteg megfelel látható valóságuknak: „mert nincs semmi a mélyben”. A dolgoknak az emberektől független létmódjánál mi sem természetesebb, hiszen még a magunk mélységeit sem vagyunk

\footnotetext{
15 Zanoaga-Rastoll (2016.) ,,animer”

16 Les mouvements littéraires. Le Nouveau Roman. Elérhető: https://www.sitemagister.com/nouvrom.htm\#axzz65QK8zjcq Letöltés ideje: 2019. 11. 16.

${ }^{17}$ bricoler - összetákolni, dikicselni, barkácsolni

${ }^{18}$ Mélice, Anne (2009). „Un concept lévi-straussien déconstruit : le bricolage”, Les Temps Modernes 2009/5 (n 656), pages 83 à 98, Elérhető : https://www.cairn.info/revue-les-temps-modernes-2009-5-page-83.htmur, Letöltés ideje : 2020. január 20. Lévi-Strauss, Claude (1990). La Pensée sauvage. Pocket

19 Jong, Martin (1994). Le Présent du passé: Essais de littérature comparée Namur, p. 128. Elérhető: https://books.google.hu/books?id=RnqM8nnoaYAC\&printsec=frontcover\&redir_esc=y\#v=onepage\&q\&f=false Letöltés ideje: 2019. 11. 16. „,sous sa technique de la surface, il se trouve sa haine de la profondeur”.
} 
képesek tudatosítani. Vercors aggódva kérdezi: „És az irodalom?”20 Simone de Beauvoir pedig azért fordul el az új irodalom alkotásaitól, mert unalmasnak tartja őket. ${ }^{21}$ Angyalosi Gergely $^{22}$ a 80-as években írt az Új Regényről: tanulmányában Simone de Beauvoir és Roland Barthes nézeteit ütközteti az irodalomról. Beauvoir azt kifogásolja az Új Regényben, hogy nem tart tükröt a kornak, nem mond véleményt a jelen politikai és szociológiai folyamatairól, és ezért azoknak, akik utánuk jönnek, nem ad támpontot, nézőpontot, értelmezést, értékítéletet, nem igyekszik formálni a jövőt. ${ }^{23}$ Roland Barthes pedig, az irodalom immanenciájának jegyében tudományos alapvetéssé teszi az irodalmi szövegek nyelvi szempontú értelmezésének elsődlegességét.

Az Új Regényírók szervesen folytatják a Mallarmé ${ }^{24}$ által már megkezdett és a szürrealisták által folytatott utat az irodalmi szöveg autotelikus formái felé, immanens, belterjes világuk kialakítása szerves továbbvitele az irodalomtörténeti előzményeknek. Fellépésükkor mégis kialakul egyfajta „régiek” és „modernek” közötti ellentét, feszültség, ami nem újdonság a francia irodalomtörténetben. Az elutasítottságot átélő Új Regény-szerzők egymástól függetlenül végezték alkotómunkájukat, nem volt egységes, a kor irodalmi tudatára befolyásoló tényezőként ható orgánumuk, mint a Gide és köre által fémjelzett Nouvelle Revue Française. Nem arról van tehát szó, hogy az új regényírók, akárcsak a szürrealisták, iskolát kívántak teremteni, tömböt alkotni, manifesztumokban megnyilatkozni, hanem arról, hogy mindnyájan új írói utakat kerestek, és Sarraute munkamódszere, céljai is egybevágtak az Új Regény más alkotóinak elképzeléseivel.

Volt azonban az Új Regény szerzői között néhány közös pont ${ }^{25}$, például Sarraute-on kívül ugyanannak a kiadónak az égisze alatt jelentek meg (Éditions de Minuit), amely korábban már Samuel Beckett írásait is közreadta, s amelynek később Alain Robbe-Grillet lett a sorozatszerkesztője.

\footnotetext{
20 Chebel d'Appollonia, Ariana (1991). Histoire politique de intellecuels en France. (1944-54). Édition Complexe p. $247 . \quad$ Elérhetö: https://books.google.fr/books?id=voHuAAAAIAAJ\&hl=fr\&source=gbs_book_other_versions Letöltés ideje: 2019. 11. 16.

${ }^{21}$ Chebel d'Appollonia (1991.) idézi Simone de Beauvoir La Force des choses „Le constant de cette littérautre, c'est l'ennui."'

${ }^{22}$ Angyalosi Gergely (1986). "Új-e még az Új Regény?" in (1996). A költő hét bordája, Debrecen, Latin Betük p. 97-106., p. 97.

${ }^{23}$ Beauvoir, Simone (1966). A körülmények hatalma (emlékezés-regény, ford. Szőllősy Klára), Bp., Magvető; Barthes, Roland (1962). Jelentenek-e valamit a dolgok?

${ }^{24}$ Maár Judit, Ádám Anikó (szerk). (1995). Nyelv, költészet, titok, Nemzeti Tankönyvkiadó

${ }^{25}$ Viart (1993) p. 110.
} 
Ugyanakkor

Nathalie

Sarraute, Alain Robbe-Grillet,

Samuel Beckett, Robert Pinget,

Claude Simon, Michel Butor, Claude

Mariac, és Jérome Lindon

megjelentek egy közös fotón, amely

a sajtóban már-már az irányzat

védjegyévé vált. ${ }^{26}$

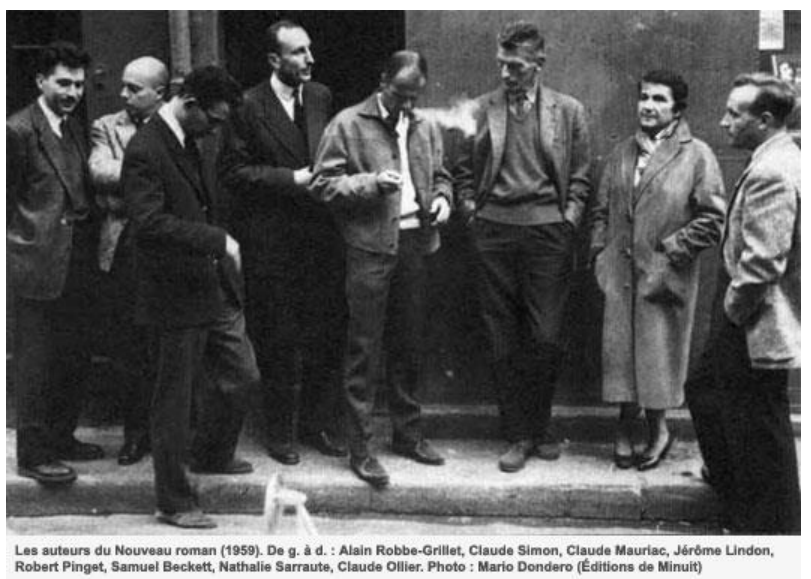

További közös pontként említhető meg, hogy az 1971-ben Cerisy-la-Salle-ban, Jean Ricardou kezdeményezésére rendezett Új Regény Konferencia összehozta az alkotókat, hiszen az irányzathoz köthető valamennyi említett alkotó részt vett rajta, kivéve Marguerite Duras és Samuel Beckett ${ }^{27}$. Itt Nathalie Sarraute is előadást tartott. ${ }^{28}$ Később, az 1980-as években az Új Regény képviselői elfordulnak a Ricardou-féle radikális vonulattól. 1982-ben New York-ban néhányan közülük, többek között Sarraute is, részt vesznek egy nemzetközi írókonferencián ${ }^{29}$, ahol tudatosan elhatárolódnak a szélsőségesen formalista alkotásmódtól. Továbbá megőrizve újszerü alkotói tapasztalataikat írói gyakorlatukban visszatérnek a klasszikus formákhoz. Többnyire önéletrajzzal jelentkeznek ebben az időszakban, műveikre az olvashatóság, illetve akár a tematizáltság lesz jellemző. Ekkor születik Sarraute Gyerekkor címü regénye, Duras megírja a Szeretőt $(1984)^{30}$, Robbe-Grillet pedig a Visszatérő tükröt $(1984){ }^{31}$

Angyalosi Gergely szerint az Új Regény elsődleges jellemzője első hullámában az „agresszív konstrukció”32, azaz az elbeszélés elleni radikális támadás. A diegézis annak esetleges ideológiai vetületei miatt válik tabuvá. Angyalosi találóan foglalja össze az Új Regény alkotóinak írástechnikáját: müködésbe hozzák a történetet, majd „kisiklatják”33.

26 Kép forrása: https://www.encyclopedia.com/literature-and-arts/literature-other-modern-languages/frenchliterature/nouveau-roman Letöltés ideje: 2019. 11. 16.

${ }^{27}$ Léal, Eugénia (2009). La Mise à mort du récit dans l'oeuvre romanesque de Robert Pinget, Peter Lang, p. 34.

${ }_{28}$ Ricardou, Jean (1972) Nouveau Roman: hier, aujourd'hui (Colloque de Cerisy-la-Salle, 20-30 juillet 1971) Poche - 1972 Problèmes du Nouveau Roman (1967), Pour une Théorie du Nouveau Roman (1971)

${ }^{29}$ Léal (2009). p. 50.

${ }^{30}$ Duras, Marguerite (1987). A szerető, Európa, Budapest, Fordította: Ádám Péter; Duras (1984). L’amant, Édition de Minuit

${ }^{31}$ Robbe-Grillet, Alain (1985). Le Miroir qui revient, Édition de Minuit ; Robbe-Grillet, Alain (1986) A visszatérő tükör, Nagyvilág : világirodalmi folyóirat 31 . évf. 1 .sz. / 1986 Elérhető: www.inaplo.hu/nv/arch/archset.html (2000-2002), Letöltés ideje: 2019. 11.16.

32 Angyalosi (1996). p. 101.

${ }^{33}$ U.o. 
Ugyanakkor Angyalosi Alain Robbe-Grillet Radírgumik címü regénye kapcsán a produkció ${ }^{34}$ elvének megvalósulását taglalja: a münek nincs klasszikus értelemben vett témája, mert a téma önmaga keletkezése.

Korunkban a franciaországi Sarraute-recepció rendkívüli módon széttartó. Számos olvasó még ma is hermetikus zártságára hivatkozva tartja megközelíthetetlennek, de egyetemi körökben kifejezetten kedvelt: ha a www.fabula.org nevü francia irodalomtudománnyal foglalkozó honlap keresőjébe beírjuk Nathalie Sarraute nevét, 337 találatunk van. Ugyanezt a keresőkérdést a www.theses.fr honlapnak szegezve 147 lesz az eredmény. Nathalie Sarraute hosszú, tiszta, befejezett életműve mondhatni, hogy Franciaországban kedvelt irodalomtudományos körökben. Mindennek bizonyítéka az, hogy müveinek létezik kritikai kiadása, illetve ezt a helyzetet az is előmozdítja, hogy nem egy kutatója egyetemi karriert futott be (Monique Gosselin-Noat, és Arnaud Rykner például), akik így a vele kapcsolatos kutatások folyamatos hátterét biztosították az elmúlt évtizedekben. A francia recepció szempontjából kiemelkedő Pierre Verdrager gyüjteményes kötete, a Le sens critique ${ }^{35}$ / [Kritikai érzék], hiszen arra kérdez rá, hogy különféle szakmabeli szereplők - írók, újságírók, egyetemi tanárok milyen eltérő véleményeket fogalmaztak meg Nathalie Sarraute életmüvével kapcsolatban. Verdrager hatalmas gyüjtőmunkával szedi össze az újságcikkeket és a kritikákat, és egyetlen szubjektív elemet sem tesz hozzá elemzéséhez. Az életmű erényei ellen és mellett felsorakoztatott érvek egymás ellenhatásaiként oltódnak ki és a konklúzióban fény derül arra, hogy a francia Sarraute-recepció önellentmondásosságában is rendkívül gazdag.

Ugyanez a magyar szakirodalomról nem mondható el, talán mert kevés fordítás született. Ami a fordítását illeti, eufemizmussal élve „hiányos” a Sarraute-irodalom magyarországi recepciója. Kevés számú szépirodalmi munkáját fordították magyarra, és még kevesebb elméleti írás vagy kritika született életmüvével kapcsolatban magyar nyelven.

- Planetárium ${ }^{36}$

- Gyerekkor $^{37}$

- Két részlet a L'Ère du soupçonból: A gyanakvás kora, Párbeszéd és belső párbeszéd ${ }^{38}$

\footnotetext{
${ }^{34}$ A produkció itt egyértelmüen Kristeva elméletére utal (production littéraire), és ezt állítja szembe a hagyományos kifejezés-ábrázolás, tehát a reprezentációra alapuló irodalomfelfogással. Az eredetiben „production” szó szerepel, de annak inkább a „létrehozás” lehetne a megfelelö fordítása. A produkció nézetem szerint nem a megfelelő szóválasztás.

${ }^{35}$ Pierre Verdrager (2001). Le sens critique. La réception de Nathalie Sarraute par la presse, Collection : Logiques sociales, L'Harmattan

${ }^{36}$ Sarraute (1973). Planetárium, ford. Farkas Márta, Magvető, Budapest

${ }^{37}$ Sarraute (1986). Gyerekkor, ford. Pór Judit, Magverö, Budapest

${ }^{38}$ Konrád György - szerk. (1967). A francia új regény, Európa, Budapest. Két részlet a L'ère du soupçonból: A gyanakvás kora, Párbeszéd és belsö párbeszéd, ford. Réz Pál
} 
- Felszólalás a brüsszeli Egyetemi Szabad Fórumon ${ }^{39}$

- Egy igenért vagy egy nemért ${ }^{40}$

- Tropizmusok ${ }^{41}$

Első írásaihoz még Sartre írt elöszót, és igyekezett teret, lehetőséget biztosítani az írónő számára a korabeli francia irodalmi életben. Sarraute azonban már nem a világra, az irodalomra, a történelemre reflektál, hanem a nyelvre magára, s ha ennek az irányultságnak a Sartre szerinti „elhatalmasodását” a többi szemponton való túlburjánzásként, túlnövekedésként értelmezi, akkor érthető, hogy ezeket a szövegeket „,antiregényként” kívánta beemelni a köztudatba ${ }^{42}$. Az Új Regény nyelvfelfogása az irodalom autonómiájának barthes-i megfogalmazásában válik a leginkább egyértelművé ${ }^{43}$. Ugyanakkor az irodalom soha nem úgy adta vissza a valóságot, ahogyan a statisztikák és a szociológiák, még az Új Regény előtt sem. Érdekes, ahogy Angyalosi Gergely az ezzel kapcsolatos kérdésfeltevést az „elfogultság” fogalma köré szervezi: Sartre elfogult-e, aki regényeiben egy bizonyos politikai és filozófiai utat tendenciózusan kínál fel az olvasónak, amelyet vele „kell” bejárnia, vagy az az Új Regény, amely „elfogultan” (S. de B. kifejezése rájuk) zárkózik el ez elől a feladat elől, és a nyelv labirintusába menekül? ${ }^{44}$

Mi hordozhatja a tartalom és a forma egységét, ha a dolgok értelme kérdőjeleződött meg a posztmodern állapotban. Az írói alany nem lehet az egység letéteményese, mert a „,Szerző meghalt”45. A dolgok vannak, és a nyelv is van. De ezek egymásra vonatkoztatása, azaz a jelentésképzés megbicsaklott. Nathalie Sarraute szerint az egységet kizárólag az írás aktusa, az írás folyamata hordozhatja. Deleuze-i kifejezéssel élve a leendés oldhatja fel ezt a problémát. A sarraute-i gyanakvás más szóval tehát sokszor artikulálatlanul (dadogás) azt a szorongást fejezi ki, hogy a szavak és a dolgok többé nem vonatkoztathatók egymásra, a szavakat köznapi jelentésüktől elválasztva, tudatosan kliséként müködteti, és így hozza létre az olvasóban az irritáltság érzését ${ }^{46}$.

Később L'ère du soupçon címü esszékötetéből nőtt ki az Alain Robbe-Grillet és Michel Butor neve által fémjelzett Új Regény-elmélet. Írásművészetének sajátosságai, a nonfiguratív, klasszikus jellemeket félreállító szereplőképzés, a kronologikus időrend hiánya, a cselekmény

\footnotetext{
${ }^{39}$ Uo. Felszólalás a brüsszeli Egyetemi Szabad Fórumon, ford. Nagy Géza

${ }^{40}$ Sarrute (2006). Egy igenért vagy egy nemért, ford. Horváth Andor, Kolozsvári Állami Színház

${ }^{41}$ Sarraute (2011). Tropizmus, részletek, ford. Lombár Izabella, in Tiszatáj, 2011. 12.Közben a teljes Tropizmusfordítás elkészült, kiadatlan

${ }^{42}$ Angyalosi (1996.) p. 97.

${ }^{43}$ Barthes, Roland (1996). "A szerző halála" in A szöveg öröme, Osiris p. 50.

${ }^{44}$ Angyalosi (1996). p. 99-100.

45 Barthes (1996). p. 50.

${ }^{46}$ Angyalosi (1996). p. 99-100.
} 
háttérbe szorítása, a bonyodalomtól és a fordulatoktól való tartózkodás mind-mind az Új Regény körébe utalják életművét. Új írói technikákat, eljárásokat keres. Ráadásul szakmailag és érzelmileg is később eltávolodik Sartre és Simone de Beauvoir köreitől és a Les Temps modernes-től, mert az 1940-es évek végén visszautasítják Conversation et sousconversation / Szó és szómögöttes címü esszéjének megjelentetését. Mind Sartre mind Beauvoir nyilvánvalóvá teszik, hogy számukra az irodalom valójában értelmezhetetlen a valóságábrázolás, sőt a társadalmi elköteleződés nélkül. ${ }^{47}$ Ha Sarraute írói törekvései egybeesnek az Új Regény szerzőiével vagy inspirálják őket, akkor inkább hozzájuk sodródik, de nem keresi semelyik írói iskola közelségét sem. Még 1971-ben is, amikor az Új Regény képviselői óriási figyelmet keltő konferencia keretében adnak számot addigi eredményeikről ${ }^{48}$, nos, még akkor is elgondolkodik azon: egyáltalán elmenjen-e előadást tartani.

Ahogyan Jean-Yves Tadié utal rá, Sarraute A gyanakvás kora címü esszékötetében nem csak kiáll a regény új formái mellett, hanem finom utalásrendszerrel, paródiába hajló nyelvi regiszterrel helyezkedik szembe a konvencionális regény formai megoldásaival, alkotóival, kritikusaival és olvasóival. Tadier egyenesen fikciós szövegnek, „gondolatregénynek” nevezi Sarraute esszékötetét. „A beszélt nyelv és a gondolatok nyelve már-már fikcióra hajló módon elárasztja a prózakritikai szöveget, olyannyira, hogy az esszé dialógusokra bomlik és gondolatregénnyé válik." ${ }^{49}$ Ez a dialógussá, paródiává, képpé formálódó kritika már nem is kritika - szépirodalom, a regény regénye, amely a Fruits d’or stílusát vetíti elöre. Mindez pedig a műfaji határok tudatos elmosódását, a fikció és a dikció együtthatását eredményezi.

„Irodalomtörténeti szempontból az Új Regény ellenállás, visszautasítás, Sartre-ral és Camus-vel való szembehelyezkedés, akiknek a munkásságát Robbe-Grillet keményen megkérdőjelezte."50 Amivel szembehelyezkedtek, az a „szavak elértéktelenedése”, az „,ideológiai mellé- és túlbeszélés” ${ }^{\text {, }}$, és ami még motiválta őket abban, hogy az erkölcsi kérdéseket felvethető cselekményvezetést és hőstípusokat kerüljék, az a politikával szembeni

\footnotetext{
47 Beauvoir, Simone de (1963). La force des choses, Collection Blanche, Gallimard in Sarraute, Oeuvres complètes (1996). p. 2078.

48 Sarraute, Nathalie (1996). "Ce que je cherche à faire", előadás az új regény képviselői számára rendezett konferencián, 1971-ben. Szervező: Raymond Jean, Jean Ricardou. A konferencia programja: az Új Regény valamennyi képviselője egy-egy előadást tart, amelyet konferenciabeszélgetés követ (Nathalie Sarraute, Claude Simon, Alain Robbe-Grillet, Claude Ollier, Michel Butor, Robert Pinget, Jean Ricardou. A konferencia előadásai és a konferenciabeszélgetések szerkesztett változata megjelent: "Nouveau roman: hier, aujourd'hui", UGE. (1972). in Sarraute (1996). Oeuvres complètes p. 2099-2100.

49 Tadié, Jean-Yves (1984). "Un traité du roman" L'Arc n 95. 1984. (55-59.) p. 59.

${ }^{50}$ Ducout, Françoise (1984). "Le nouveau roman : vingt-cinq ans après" L'Arc 95 (1984). p. 71. „Historiquement, le NR se veut protestation, refus, Face à Sartre et à Camus, âprement remis en question par Robbe-Grillet."

51 ,l'inflation verbale”, ,bavardage des idées” U.o.
} 
bizalmatlanságuk $^{52}$ a II. világháborút, illetve az algériai háborút követően. Az irodalmi önkifejezés elsődleges terepe a formák, a stílus, a figurák, a nyelvhasználat lett. Roland Barthes kifejezéseivel élve „objektív irodalom”53, illetve „szó szerinti irodalom”54 lett, melyből száműzték a történetet és a szereplőket.

Michel Butor 2016-ban bekövetkezett halála kapcsán Magyar Miklós azt az értelmezést adja az Új Regény nevű irodalmi csoportosulásnak, hogy bár törekvései irodalomtörténetileg logikusak voltak az avantgárd és az egzisztencialista elődök müvének folytatásaként, ám kevés számú olvasótáboruk miatt „megbuktak”, és mára csupán nem több a munkásságuk, mint irodalomtörténeti érdekesség. Különös, amit Magyar Miklós állít. Azt a „munkát”, „erőfeszítést”, ahogy Nathalie Sarraute minősíti saját írói tevékenységét, amelyet az Új Regény képviselői elvégeztek, befektettek a mai irodalomba, nem tekinteném elvesztegetettnek. Szerepe abban állt, hogy az írók és az olvasók figyelmét a prózaírás tekintetében elfordította a cselekményvezetésről, és a leírások, a párbeszédek, az időkezelés és a nonverbális gesztusok felé terelte.

A szereplőfogalom dekonstrukciója révén finoman, a szépirodalmi eszköztár bravúros stílusú mozgósítása révén jelenítették meg a korszak írói a szubjektum jellegzetes szétesését. A lírában a francia szimbolikusoktól kezdve egyértelműen jelen lévő, szinesztézikus poétikát ${ }^{55}$ az epikára alkalmazták. Ezek az írói gesztusok a mai napig jelen vannak, akár a sokarcú Darrieussecq-életmüben, akár, hogy magyar nevet is említsek, Mészöly Miklós alkotásaiban. A következő kérdésfeltevések állnak a középpontban: Mi van előbb, az író vagy a műve? Honnan az alkotás, a szavakból vagy az érzékekből, vagy valamiféle Érzékfelettiből? Szükség van-e valóban a cselekményvezetés (próza) vagy az „üzenet” (líra) szintjén verbaizálódó konfliktusra, bonyodalomra, fordulatra, gondolati tartalomra, hogy a szenvedés tragikumát érzékeltessük? Mi az, megfogalmazni valamit? Hogyan lehet szavakban megragadni a megragadhatatlant?

Nem gondolom, hogy a francia Új Regény megbukott. A mai kevert, klasszikus narratívákat és modern írói eljárásokat is alkalmazó irodalom az ő „erőfeszítéseik ${ }^{56 ”}$ nélkül nem jöhetett volna létre.

\footnotetext{
52 ,soupçon en la politique” U.o.

53 littérature objective in Barthes, Roland (1954). "Littérature objective" Critique 1954. Elérhető: http://aelib.org.ua/texts/barthes__essais_critiques_fr.htm\#07 Letöltés ideje: 2020. 01. 06.

${ }^{54}$ littérature littérale U.o.

${ }^{55}$ Jacobson

${ }^{56}$ effort: N. Sarraute kedvelt kifejezése az írás folyamatára.
} 


\section{A szereplö fogalmának értelmezése}

\section{III.1. A klasszikus arisztotelészi poétika szereplöértelmezésének válsága - az 1920-as, 30-as évek szereplőelméletei}

Arisztotelész Poétikája ${ }^{57}$, bár mondanivalója a színházelmélettel kapcsolatos, már tartalmaz szereplőre való utalásokat. A IX. fejezetben megfigyeléseket és normatívákat találunk a szereplők elnevezéséről, a karakterek felépítéséről. Azt javasolja, hogy egyrészt ne legyen önellentmondás a megalkotott jellemben (a zsugori soha ne legyen nagylelkü és fordítva), illetve hogy a szereplő cselekedetei mindig legyenek összhangban a jellemével. A XVII. fejezetben azt a tanácsot adja az írónak, hogy helyezkedjen bele maradéktalanul a megformálni kívánt szereplö érzelmi világába, mert így fogja tudni hatásosan megalkotni hősét. A felvilágosodás korában Diderot számára a szereplő a drámai műnemben megjelenő személyeket jelenti.

Elsősorban a XIX-XX. század fordulójától kezdve veszik fel a fonalat a szerzők a szereplö elméleti megközelítésével kapcsolatban. A XIX. századi realista művek hagyományos regényértelmezése társadalmilag, pszichológiailag felépítettnek, ezért szinte önálló életet élő, „,valós” személyként adottnak veszi a szereplőt. Lukács György ${ }^{58}$ az 1920-as években formálja meg regényelméletét. A szereplőkre vonatkozóan három tipikus formát különít el: az első az idealista regény főhőse, beszűkült tudatú démoni figura, aki nem képes átlátni a világ összetett rétegeit. Példának Cervantes Don Quijotéjét vagy Stendhal Vörös és feketéből Julient hozza fel. Másodiknak a lélektani regény passzív hősét említi, akinek lelke túl tágas ahhoz, hogy képes legyen alkalmazkodni a világhoz. Itt Flaubert Érzelmek iskolájából Férédéric Moreau-t említi. Harmadikként a nevelődési regény tudatos lemondást, de nem belenyugvást és nem is reménytelenséget megélő hősét emeli ki, például Wilhelm Meistert Goethétől. Ez utóbbi regénytípusnak szerinte az erénye a problematikus embertípus társadalmi valósággal és világgal való kiengesztelődésének bemutatása, a két első szereplőtípus szintézise. Valahol a vágy továbbél a XX. század eleji teoretikusokban is arra nézve, hogy a valóságot és az irodalmi szöveget közös nevezőre hozzák, „kiengeszteljék” Lukács szavaival élve. Ezzel ellentétben Mauriac is utal arra 1930-as években született esszéjében, hogy a valóságot és a fikciót nem lehet összemosni.

\footnotetext{
${ }^{57}$ Arisztotelész, Poétika, Elérhető: http://mek.oszk.hu/00300/00315/00315.htm, Letöltés ideje: 2019. 07. 16.

${ }^{58}$ Lukács György. A regény elmélete Elérhető: http://www.balassikiado.hu/BB/NET/Lukacs/1_9.pdf Letöltés ideje: 2019. 07. 16.
} 
Egyébként 1964-ben Lucien Goldmann Pour une sociologie du roman [A regény szociológiája $]^{59}$ címü regényelméleti munkája Lukács György gondolatmenetét folytatja, a regények szociológiai vizsgálatának fő lehetőségeit tárja fel. Goldmann ${ }^{60}$ nézetei szerint az aktuális elbeszélői formák és a társadalmi állapotok között hatalmas a szakadék, bár az előbbi az utóbbi alapvető individualizmusából nőtt ki. Pontosan emiatt a felismerés miatt számára is a szereplő mint a narrativitás egyik alappillére elméletének sarkpontja: Goldmann úgy látja: a szereplő problematikája, hogy hiteles értékekre törekszik egy hitelességtől megfosztott valóságban. „Kortárs irodalmunkban párhuzamos átalakulás zajlik - ahogyan formálódik át a regény müfaj és felszámolja önmagát, úgy tünik el fokozatosan a hős, az individumként értelmezhető szereplö."61. Goldmann igyekszik összefüggést keresni a társadalmi-gazdasági átalakulás és a regényekben megjelenő történetek és hősök között. A felvetett kérdések rendkívül érdekesek és az egyes regényekkel kapcsolatos gondolatok is, de annyira széttartó az irodalmi termés, hogy átfogó rendszert vagy valamennyi műre érvényes értelmezési keretet adni a XX. század elején átalakuló és születő regénynek már nem lehet. Joyce, Kafka, s később Robbe-Grillet, Sarraute már nem keresi a lehetőséget, hogy értelmet adjon a helyzeteknek, a változásoknak, ha nagy szavakat használunk, a Történelemnek, nem próbál még lélektani magyarázatokkal sem szolgálni a létrehozott szövegvalóságban. Kafka például abszurd világot hoz létre, Robbe-Grillet tárgyai pedig szinte önálló életre kelnek. Annyira halvány vagy sokrétü ezeknek a belterjes szövegvilágoknak a kapcsolata magával a valósággal, hogy a kapcsolat keresése vagy leírása tudományos szinten akadályba ütközik, nem részletezhető, nem is feltétlenül bizonyítható. Amit az értelmező biztosan képes vizsgálni, az a szövegek belső szerkezete.

Az 1920-as évek végén léptek fel továbbá az orosz formalisták ${ }^{62}$ is, köztük Vladimir Propp $^{63}$, akiknek a munkái az 1960-as évekig lappangtak, majd angol nyelvű fordításuk után tudományos eredményeik beépültek az akkor ismert strukturalista irodalomelméletbe. A formalisták elindultak azon az úton, amelyet Mauriac már említett, nevezetesen hogy a szereplő jel, és mint ilyen, nem a valóság leképezése, hanem a narratív modell egyik részeleme a téma, a cselekményszerkezet, illetve az idősíkok mellett. Ezeknek a narratív

\footnotetext{
${ }^{59}$ Goldmann, Lucien (1964). Pour une sociologie du roman, Collection Bibliothèque des Idées, Gallimard

${ }^{60}$ Zéraffa M., Goldmann L. (1965). "Pour une sociologie du roman". In: Revue française de sociologie, p. 251252; Elérhetö: https://www.persee.fr/doc/rfsoc_0035-2969_1965_num_6_2_1915 Letöltés ideje: 2019. 07. 16.

${ }^{61}$ François Chatelet (1965). "Peut-il y avoir une sociologie du roman ?" in Annales Année 1965 20-3 p. 490502. Elérhetö: https://www.persee.fr/doc/ahess_0395-2649_1965_num_20_3_421291 Letöltés ideje: 2019. 07. 17. idézi Goldmann-t. "Nous assistons à une transformation parallèle de la forme romanesque qui aboutit à la dissolution progressive et à la disparition du personnage individuel, du héros"

${ }^{62}$ franciaországi megismerésükben kiemekedő szerepe volt Todorovnak és Kristevának

${ }^{63}$ Propp, Vladimir (1970). Morphologie du conte, Seuil, Point/Essai (1928)
} 
részelemeknek az összessége alkalmas arra, hogy meghatározzuk az alkotás münemét (pl. epikus), majd a müfaját (pl. mese).

A hős fogalmát ragadja meg B. Tomasevszkij ${ }^{64}$ : a hős elkülönül a többi szereplőtől, ,a hőshöz füződő érzelmi kapcsolat (szimpátia-antipátia) morális alapokon nyugszik. A pozitív és negatív típusok szükséges elemek a meseszövés megszerkesztettsége szempontjából (...) a szereplőt, aki az érzelmileg leginkább erőteljes és életszerü színezetet kapja, hősnek nevezzük." ${ }^{95}$ Hamon $^{66}$ szerint a kultúra értelmezhető úgy, mint értékrendszer, amely euforikusan (pozitívan) vagy diszforikusan (negatívan) konnotálja a jelentés alapstruktúráinak pozitív és negatív, szintén bináris pólusait. A szereplő milyenségének leírása: jellegzetes tulajdonságai, családja, kihez tartozik, neve, fizikális leírása, hőstettei, lelki motivációi, antropomorf mivolta a fó értelmezési irányok, továbbá kapcsolata a narrátorral, társadalmi státusza, kapcsolatai a többi szereplővel (pl. szerelmi kapcsolatok), a társadalmi vagy kulturális csoportba tartozás mind minőségileg megkülönböztető jegyek, amelyek Tomasevszki szerint mennyiségi elemek értelmezési körével bővülhetnek: mikor, hol és hányszor jelenik meg a történetben (elején, közepén, végén, sokszor, ritkán, epizodikusan).

Az orosz formalizmus, majd a strukturalizmus tehát abban közös, hogy funkcionális definíciót ad a szereplőnek és a narratológiai elemzés egyik összetevőjeként tételezi. Az orosz formalista, Vladimir Propp 1928-ban harmincegy szereplői funkciót különített el. A későbbi narratológia egyik előfutáraként maga is olyan elbeszélői sémákat keres, amelyek önmagukban változatlanok lennének, és különféle kombinációik révén eltérő regényeket kaphatnánk. A formalisták elméleti előrelépésével egyidőben Saussure a Niebelungiakhoz kapcsolódó jegyzeteiben a szereplő vizsgálatát narratív szintaxisnak alávetett megkülönböztető jegyek kombinációjaként javasolja. ${ }^{67}$ Compagnon is felhívja a figyelmet arra, hogy a Saussure e korszakban születő nyelvelméletében megjelenő önkényes nyelvi jel elgondolása az irodalmi szövegek nyelvi megalkotottságának és a valóságreprezentációnak a szétválasztásához vezetett ${ }^{68}$. Ebben az értelemben a szövegnek nem létezne jelöltje a valóságban, ahogyan az orosz formalisták utalnak is erre: „a szereplő csupán motívumok

\footnotetext{
${ }^{64}$ Tomasevszkij (2001). "Irodalomelmélet" in. Bókay Antal - Vilcsek Béla (szerk). A modern irodalomtudomány kialakulása, Budapest, Osiris p. 268-287. "A hös" p. 281-289.

${ }^{65}$ Todorov (1965). p. 295. "Le rapport émotionnel envers le héros (sympathie-antipathie) est développé à partir d'une base morale. Les types positifs et négatifs sont un élément nécessaire à la construction de la fable (...) le personnage qui reçoit la teinte émotionnelle la plus vive et la plus marquée s'appelle le héros"

${ }^{66}$ Hamon (1972)

${ }^{67}$ Avalle, D.S. és tsai (szerk) (1973). Essais de la théorie du texte. La sémiologie de la narrativité chez Saussure, Paris, Galilée, p. 28

${ }^{68}$ Compagnon, Antoine (1998). Le démon de la théorie, Paris, Seuil, p. 105.
} 
foglalata”, tehát „,szöveglény”. ${ }^{69}$ Az orosz formalisták tehát hidat képeznek a XIX. századi kritikusok és a strukturalisták között. Az előbbiek értékelő és normatív attitüdjétől elszakadnak, a változóval szemben valamiféle változatlant keresnek a szövegben, s a szereplő tekintetében így jutnak el létezésétől, leírásától annak cselekvő, valamint funkcionális mivoltáig. ${ }^{70}$

Francois Mauriac (1933) a szereplő elméletét a regény válságának értelmezésébe ágyazza. Kortársai, Henry James $(1884)^{71}$ és Sigmund Freud $(1915)^{72}$ nézőpontja pszichologizáló volt, azzal a különbséggel, hogy Jamest íróként érdekelte a lélek világa, Freud pedig pszichoanalitikus elmélete megalkotásához keresett az irodalomban nagy mennyiségü példatárat. Ugyanakkor már Paul Valéry irodalmi babonaságnak nevezi azokat a hiteket, elképzeléseket, amelyekben közös, hogy szerintük az irodalom nem elsősorban nyelvhasználat, a szavakban lelt öröm. Már ő sem hisz a szereplő pszichológiai felépítettségében, felépíthetőségében, és valódi mélység nélküli lényeknek titulálja a hősöket. ${ }^{73}$ Teszi mindezt azután, hogy a XIX. században a realizmus korszakának írói, Balzac, Stendhal mintha önálló életet élő szereplők létrehozásában versengtek volna, s azok után, hogy a XX. században a pszichoanalitikus megközelítésnek köszönhetően azért a szereplő jelentősége növekszik, és Prousttal például az énelbeszélés módozatai egészen magas szintre jutnak. Paul Valéry Füzeteire csak halála után találtak rá, és előadásait sem adatta ki még életében. Pedig ezekben az esszéisztikus írásokban már csírájában megtaláljuk a különböző szövegimmanens irodalomelméleteket: az irodalmat mint a tiszta önkifejezést, amely elsősorban mint nyelvi tárgy értelmezhető ${ }^{74}$.

François Mauriac: Le romancier et ses personnages [A regényíró és szereplöi] címü írásában ${ }^{75}$ már a 30 -as években foglalkozik a szereplőnek a korszak regényírásában megújult helyzetével. Tiszteli Proustot és megérti, hogy új regényelmélet van születőben, mégis úgy értékeli, hogy az új elbeszélői eljárások óhatatlanul ötvöződnek majd a klasszikus regény értékteremtő attitüdjével, hiszen a művészet elsődleges eszköze a sűrítés, és mindig jelszerü

\footnotetext{
${ }^{69}$ Todorov, Tzvetan (1965). Théorie de la littérature, Paris, Seuil, p. 293. „le personnage n'est qu'un "support" de "motifs"

${ }^{70}$ Propp (1970). p. 29.

${ }^{71}$ James, Henry (2010). Picture and Text, FQ Books

${ }^{72}$ Freud, Sigmund (2001). Sigmund Freud müvei IX. Müvészeti írások, ford.: Bókay Antal, Erős Ferenc, Halasi Zoltán, Filum Könyvkiadó, Bp. Eredeti: Vorlesungen zur Einführung in die Psychoanalyse, 1916-17

${ }^{73}$ P. Valéry, Tel Quel „Superstitions littéraires - j'appelle ainsi toutes croyances qui ont de commun l'oubli de la condition verbale de la littérature. Ainsi existence et psychologie des personnages, ces vivants sans entrailles."

${ }^{74}$ Maár (szerk.) (2011). p. 696.

${ }^{75}$ François Mauriac (1972). Le romancier et ses personnages, Le livre de poche, eredeti kiadás Edmond Jaloux előszavával: Buchet-Chastel 1933, Elérhető: http://lettres.ac-rouen.fr/francais/fx_gide/mauriac.html Letöltés ideje: 2019. 07. 15.
} 
lesz, hiszen a való élet zavaros és kiismerhetetlen. Példának Gide müveit hozza fel, elsősorban a Pénzhamisitók $k^{76}$ és a Mennyország kapuja címü regényeit ${ }^{77}$.

„Igazság szerint (a szereplők) jelek. Nem az alkotási folyamat eredményei, ha alkotáson azt értjük, hogy a semmiből valamit teremtünk. Állítólagos teremtményeink a valóságmorzsákból formálódnak; többkevesebb érzékkel elegyítjük az embertársaink megfigyeléséből és önmagunk megismeréséből adódó tudásunkat. A regényhősök az író és a valóság kapcsolódásából születnek"78.

Írja Mauriac, majd úgy folytatja, hogy nehéz megmondani, mi az a müvében, amit az író kitalált, és mi az, amit a valóságból lesett el. Az élet kusza, önellentmondásos, zavaros, a lét törvényei homályosak, érzelmeink percről percre változnak és alakulnak, az író mégis vállalja annak a kockázatát, hogy megállítja egy pillanatra az időt, kimerevít személyeket és szereplővé teszi őket, kiragad meséket a történelemből, és ezért a bátorságáért tiszteletet érdemel.

„A részekből egyesével építve jól megalkotott teremtményt hozunk létre. Szereplőink érvelnek, világos, értelmezhető gondolataik vannak, pontosan azt teszik, amit szeretnének és logikusan járnak el, pedig a valóságban a tudatalatti lényünk lényegi meghatározója és cselekedeteink nagy részének még mi magunk sem ismerjük az okát." ${ }^{\text {79 }}$

Mauriac szerint tehát ellentmondás feszül a fikciós világ és a való világ között abban az értelemben, hogy a való világ összetett, kiismerhetetlen és zavaros, a regényvilág pedig jelszerü, megkomponált, sürített struktúra. Azzal kívánja feloldani ezt a bináris oppozíciót, hogy ne versengésnek fogjuk fel: vagy a valóságot mutatja be, és akkor tényleg a valóságot, vagy nem és akkor nem. Hanem a müvészet lényege szerint önkényes, ezért nem tudja a maga összetettségében ábrázolni a valóságot, legfeljebb stilizálja, transzponálja, átalakítja. És nem is érdemes törekedni az élet összetett valóságának az ábrázolására, mert mindinkább próbáljuk, annál müvibb, erőltetettebb lesz az alkotás. „A valóságot csak „tükör által, homályosan” láthatjuk a regényekben. Bele kell nyugodnunk: ennek a müvészi ágnak vannak konvenciói, hazugságai” ${ }^{\circ 0}$. Arról a mauriaci gondolatról, hogy az írók által létrehozott szereplők szabad, cselekvő individuumoknak tekinthetők, eszünkbe juthat Ernest Pinard

\footnotetext{
${ }^{76}$ Gide André (1966). A pénzhamisitók; ford. Réz Pál, utószó Mesterházi Lajos; Európa, Bp.;

${ }^{77}$ Gide André (1944). A mennyország kapuja; ford. Gyergyai Albert; Franklin, Bp., 1944 (Külföldi regényírók)

${ }^{78}$ Mauriac F (1972) „A la vérité, ils en sont les signes. Les personnages qu'ils inventent ne sont nullement créés, si la création consiste à faire quelque chose de rien. Nos prétendues créatures sont formées d'éléments pris au réel; nous combinons, avec plus ou moins d'adresse, ce que nous fournissent l'observation des autres hommes et la connaissance que nous avons de nous-mêmes. Les héros de romans naissent du mariage que le romancier contracte avec la réalité."

${ }^{79}$ Uo. „Nos personnages raisonnent, ont des idées claires et distinctes, font exactement ce qu'ils veulent faire et agissent selon la logique, alors qu'en réalité l'inconscient est la part essentielle de notre être et que la plupart de nos actes ont des motifs qui nous échappent à nous-mêmes."

${ }^{80}$ Uo. „,...) atteindre le vrai que par réfraction. Il faut se résigner aux conventions et aux mensonges de notre art."
} 
államügyész Flaubert elleni beszéde, amelyben 1857-ben Emma Bovary szereplőt azzal vádolta, hogy nem szerette a férjét ${ }^{81}$.

Ilyen értelemben a pszichologizáló attitüd már itt, az 1920-as, 30-as években kritika tárgya, hiszen a szöveg részeként értelmezett szereplő indítékait, viselkedését, kapcsolatrendszerét nem lehet úgy értelmezni és elemezni, mintha valóságos személy lenne.

\section{III.2. Az Új Regény a szereplöről}

\section{III.2.1. Alain Robbe-Grillet elméleti megközelítése}

A nyelvészeti fordulatnak nevezett elméleti átalakulásnak különféle új fórumok adtak teret az 1940-es évek végétől: Les Temps Modernes, Critique, Tel Quel. Ezeknek a társadalomtudományi folyóiratoknak a lapszámaiban fejtik ki nézeteiket azok a tudósok és irodalmárok, akik felismerik az ideológiák csődjét ${ }^{82}$ és nem nyelvkritikát hajtanak végre, hanem az irodalmi müvek nyelvi megformálásától már többet várnak, mint hogy a gondolatok puszta csontvázai legyenek: maga a nyelv az irodalmi mü konstrukciójának egyetlen mozzanata. Maurice Blanchot ide kapcsol vissza a „semleges hang intranzivitásának”, az autonóm irodalomnak a gondolatával, amelyet a Nouvelle Revue Française hasábjain megjelenő, gyakran olvasmányélményeit feldolgozó cikkeiben tár fel. ${ }^{83}$

Az Új Regény megjelenésekor az érdeklődő sajtó a legkülönbözőbb elnevezésekkel illette a klasszikus regényhagyománytól eltérő alkotásokat: „új realizmus”, „megújuló teremtés regényei”, fehér regények” "84, „az elutasítás iskolája”, „regényesség nélküli regény” ${ }^{\circ 5}$, „ifjú regény”, „a dolgok kora” „objektív regény”86, „laboratóriumi regény”, „mérnökregény”, „kísérleti regény”87, „Minuit iskola” ${ }^{88}$. Az újdonság erejének rögzítése a névben több esetben is nyilvánvaló: elutasítás, megújuló, ifjú. Valami egészen új készülődik, s mindez a nyelv szintjén, a stílus szintjén, a szövegszerü megalkotottság segítségével. Amikor olvasmányélményeikről beszélnek, akkor is egészen hasonló íróelődökről számolnak

\footnotetext{
${ }^{81}$ Pinard, Ernest, Procès de Madame Bovary : réquisitoire in Flaubert, Euvres Elérhető: https://flaubert.univrouen.fr/oeuvres/mb_pinard.php Letöltés ideje: 2019. 07. 20.

${ }^{82}$ Maár (szerk.) (2011.) p. 785.

${ }^{83}$ Uo. p. 788.

84 ellentétben a „roman noir” műfajával, azaz a fekete regénnyel, amely a franciáknál krimit jelent. Uo. p. 803.

${ }^{85}$ utal a klasszikus regénynarratíva eszközeinek tudatos háttérbe szorítására

${ }^{86}$ Roland Barthes kifejezése, azzal együtt, hogy „littérature littérale” / szó szerinti irodalom in Viart (1993.) p. 120.

${ }^{87}$ a mérnöki, objektív, laboratóriumi kifejezések utalnak arra, hogy nem ihlet, hanem tudatos stílusválasztás és nem ösztönös nyelvteremtés, hanem tudatos nyelvi tervezés áll a regények megalkotása mögött

${ }^{88}$ „nouveau réalisme”, „le temps des choses”, „roman d'une nouvelle genèse”, „romans blancs”, „école du refus”, „roman objectif”, „roman sans romanesque” ,jeune roman” „roman de laboratoire” ou „d'ingénieurs” „roman expérimental” „école de minuit” in Viart (1993) p. 109.
} 
be: Flaubert, Proust, Joyce, Kafka, Faulkner, Dosztojevszij, Virginia Woolf. Mindnyájan közösek abban, hogy a gyanakvásnak még nem alávetett tudati szinteket jelenítenek meg egészen különböző irodalmi formákba öntve. ${ }^{89}$

Alain Robbe-Grillet: Pour un nouveau roman (Az új regényért) (1963) ${ }^{90}$ - az író 1956 és 1963 között született irodalmi tárgyú tanulmányait tartalmazza. A szerző túlhaladottnak tartja a hagyományos narratív eljárásokat, például a szereplő megjelenítését, a történetet vagy a politikai, ideológiai elköteleződést. Elismeri, az új regény tartozik Sartre-nak és Camus-nek, mégis úgy határozza meg ezt az irányzatot, mint müvészi utat, keresési folyamatot. Nehezebb nem kész jelentéseket tárni az olvasó elé, nem egyszerü nem elköteleződni csak egyetlen valóság, az irodalom iránt. „A világ se nem tragikus, se nem abszurd” - vallja Robbe-Grillet ${ }^{91}$ és határolódik el a mondat segítségével mind a romantikus, mind az egzisztencialista regényírói hagyománytól:

\begin{abstract}
„Eleget szónokoltunk a szereplőről! Hiába, még mindig szó van róla! Ötven év betegeskedés után, azután, hogy legkomolyabb esszéíróink többször is a szereplő halálát jelentették, még mindig győzelmesen áll a vártán, ott, ahová a XIX. század állította. Hiába lett mára múmia, még mindig ugyanazzal a fenséges attitüddel trónol - ha mégoly müvi pózban is - a tradicionális irodalomkritika által megálmodott értékek kellős közepén. Sőt, innen ismerszik meg az „igazi” regényíró: „szereplőket képes megalkotni”." 92
\end{abstract}

Lehet úgy regényeket írni, hogy az író tudatosan nem szeretné meghaladni Bovaryné, a Karamazov testvérek vagy más klasszikus regényhősök portréjának precizitását, plasztikusságát, szépségét, sőt, éppenhogy el kívánja kerülni ezt a versenyt és valami egészen másra kíván koncentrálni alkotáskor? Mi van azzal az íróval, aki nem szeretne „személyt” láttatni a művében megalkotott szereplő által, személyt a maga nevével, felmenőivel, foglalkozásával, lakhelyével. Nem szeretne tulajdonságokat, személyiséget varázsolni e szereplő köré, és nem kívánja, hogy a szereplő személyisége az arcán tükröződjön. Továbbá nem kívánja, hogy személyiségének megfelelő szerepe, hatása legyen a többi szereplőre és a regény cselekményére.

Robbe-Grillet a továbbiakban az individuum felemelkedésével és bukásával magyarázza a XIX. századi regényhős megalkotottságát és a vele kapcsolatos XX. század

\footnotetext{
${ }^{89}$ Uo. 113

${ }^{90}$ Alain Robbe-Grillet (2013). Pour un nouveau roman, p. 192. Első kiadás: Éditions de Minuit 1963. Elérhető: http://lpbduby.fr/data/documents/alain_robbe_grillet_le_personnage_de_roman.pdf Letöltés ideje: 2019.07. 15

${ }^{91}$ Viart (1993). p. 112. „Le monde n'est ni tragique ni absurde”

92 Robbe-Grillet (2013). "Nous en a-t-on assez parlé du 'personnage'! Et ça ne semble, hélas, pas près de finir. Cinquante années de maladie, le constat de son décès enregistré à maintes reprises par les plus sérieux essayistes, rien n'a encore réussi à le faire tomber du piédestal où l'avait placé le XIXe siècle. C'est une momie à présent, mais qui trône toujours avec la même majesté quoique postiche au milieu des valeurs que révère la critique traditionnelle. C'est même là qu'elle reconnaît le 'vrai' romancier : 'il crée des personnages'..."
} 
eleji „gyanakvást”. Az egyetemes sors fogalma helyébe az egyénileg megélt út és érzelmek kerültek, tehát az identifikáció fogalma már nem értelmezhető, nem tudunk azonosulni a szereplökkel. A realizmus korában még volt értelme a sikernek, a kudarcnak, a hatalomnak. „Még jelentett valamit, hogy arcunk volt egy olyan univerzumban, ahol a személyiség egyszerre jelentett megtalálandó eszközt és célt az emberek számára."93

Az Új Regény körébe tartozó egyik legtöbbet elemzett és emlegetett regény Michel Butor 1957-ben megjelent Módosulás című regénye. ${ }^{94}$ Különleges elbeszélői eljárások és a megnyilatkozások irodalmi szintre emelésének sajátos vonásai jellemzik, mindemellett tárgyakat, dolgokat helyez a müve középpontjába. Már-már az olvasót teszi meg szereplővé egyes szám második személyü narratívája segítségével, amelyben egy két város, Párizs és Róma és két nő között őrlődő sors vonásait idézi meg. ${ }^{95}$ Butor, akárcsak Robbe-Grillet, tudatosan torzítja a szereplő jelölőjének grammatikalitását, stabilitását epikus műveikben. ${ }^{96}$ Pedig a szereplő napja már régóta leáldozóban van: Nathalie Sarraute 1936-ban megfogalmazza a regényhős iránti elbizonytalanodást, gyanút. Az Új Regény hőse lassan elveszti gyökereit, elődeit, társadalmi státuszát, életterét, javait, arcát, jellemét, sőt, a nevét is.

\section{III.2.2. Nathalie Sarraute a szereplöröl}

A narratológia egyik legfontosabb kérdésfeltevése a valóság és a fikció viszonya, az utánzás, reprezentáció, valószerüség, fikció, illúzió kifejezések némelyikét és a valóság és az irodalom elképzelt, lehetséges világa közötti kapcsolat leírásának első kísérletét Arisztotelésznek tulajdonítják. Poétikájában az illúziókeltést tartotta a müvészet egyik szerepének. „(...) nem az a költő feladata, hogy valóban megtörtént eseményeket mondjon el, hanem olyanokat, amelyek megtörténhetnek és lehetségesek a valószínűség vagy a szükségszerüség alapján" "97. A feltételes mód használata itt is arra utal, hogy a valóságot a szöveg mindig csak áttételesen képes ábrázolni. A „gyanakvás”98 fogalma Sarraute-nál hangsúlyosan jelentkezik (mücím, kötetcím), ugyanakkor mint a szöveg tartalmi jelentésességének megkérdőjelezésére használt fogalom, továbbél. Antoine Compagnon is ezt

\footnotetext{
${ }^{93}$ Uo. „C'était quelque chose d'avoir un visage dans un univers où la personnalité représentait à la fois le moyen et la fin de toute recherche."

${ }^{94}$ Butor Michel (1997). Módosulás; ford. Szathmári Éva; Noran, Bp.

${ }^{95}$ Viart (1993). p. 115.

${ }^{96}$ Ricardou, J. (1971). Mort du personnage fictif, in Pour une théorie du nouveau roman, Paris, Éd. du Seuil, p. 235.

${ }^{97}$ Arisztotelész: Poétika, Budapest, Kossuth, 1992. 18.

${ }^{98}$ Compagnon, Antoine (1998) p. 106. „méfiance”
} 
használja a mimézisbe, azaz a humánumba, az ideológiákba, az ábrázolás ártatlanságba vetett hit krízisére. Annak a meggyőződése vált bizalmatlansággá, hogy a nyelv képes a valóságot (legyen az érzékekkel felfogható vagy doxikus, ideologikus) ábrázolni.

Nathalie Sarraute A gyanakvás kora címü esszéjében az érvelés logikájának középpontjába a főhős iránti bizalmatlanságot helyezni. Gyakorlatilag a szereplő helyzetének, ellehetetlenülési folyamatának bemutatása révén invalidálja a további narratív mozzanatokat, a cselekményt és az időfaktort. Sarraute számára a szereplő kivonása a regényből: az Új Regény kulcsa. Azt vizsgálja, milyen irodalmi jelenségek, müvek milyen reakciókat váltottak ki. Csak áttételesen szól a világ és a regényben megjelenő cselekmény kapcsolatáról és alapvetően a regények recepciójában megjelenő, az olvasók részéről tanúsított zárkózott zavarodottságot hangsúlyozza ${ }^{99}$. Ugyanakkor a szereplöben való hit először az olvasóban, majd az íróban rendül meg. Ennek következében az olvasó és az író között kölcsönös bizalmatlanság alakul ki. ${ }^{100}$ A Sarraute által tudatosan használt írói eszközök nem titkoltan az olvasó által megszokott valóságillúzió megtörését, és nem kialakítását célozzák. Nem kívánták fenntartani a fikcionális világ valószerüségének látszatát. Az esszéjében említett végzetes, spontán eltávolodást író és olvasó között Sarraute konstatálja, ugyanakkor kitart a klasszikus narratíva technikáitól való tudatos elkülönülés mellett. Az írónő kérdésfeltevésének alapja nem elméleti jellegü: minden egyes esszéje szépirodalmi írásaiból levont következtetés, gyakorlati tapasztalat ${ }^{101}$. Ugyanakkor megírásuk stílusa is a szépirodalmi munkák tropizmikus, szövegmögöttest kibontó nyelvhasználatát idézi, alátámasztva ezzel az elmélet és a gyakorlat elválaszthatlanságát. Maga az alkotás a szöveg szintjén jön létre, tehát valamilyen módon és mértékben eltávolodik tárgyától, és az a kérdés, hogy milyen módon és mértékig.

Amikor Sarraute-ot az érdekli, hogy a szerző és a befogadó miért fordult el a regényhőstől, akkor máris olyan müvészi eljárásokat keres, amelyek visszavezethetnék az olvasót a művel való hiteles találkozáshoz ${ }^{102}$. Az olvasó és az író közötti megtört bizalom helyreállításának kísérlete szerinte a kortárs irodalomban már nem lehet a hitelesen szuggesztív főhős felépítésének függvénye. Valamiféle nyelven kívüli valóságban való fizikai-érzelmi egyesülés révén kerülhet kapcsolatba az olvasó a szöveggel. Talán az André Gide-féle „életintenzitás” elvével állíthatjuk párhuzamba az írónő gondolatmenetét ${ }^{103}$.

\footnotetext{
${ }^{99}$ Sarraute, Nathalie (1967). "A gyanakvás korszaka" in Konrád György (szerk.), A francia „új regény”, Bp., Európa Kiadó, p. 7., Sarraute, N. (1956). L’ère du soupçon (Essais sur le roman) Paris, Gallimard 100 Sarraute (1956). p. 60-63.

101 Sarraute (1956). Préface. p. 7-12. Nem csak itt, minden előadásán és fórumon elmondja, hogy először alkotó volt, és az abból leszürt tapasztalatait rendezte elméletbe.

102 Uo. p. 8.

103 Konrád (1967). p. 11.
} 
Ahogyan Gide mondja - „Határozottan úgy tünik, hogy a megjelenő életintenzitásból nyeri valamely dolog az értékét. Lehet ez az alkotó művész élete vagy az ábrázolt tárgyé."104 Ugyanez az ethosz, az élet és a müvészi ábrázolás titkos, misztikus szövetségének fenntartása Sarraute prózaetikájában is követelmény, viszont megvalósítását nem a hőssel való identifikáció segítségével képzeli el.

A hagyományos narratív eszközök, többek között a mindentudó narráció, a föhős klasszikus eljárásokkal (pl. jellemábrázolás, leírás) való felépítése helyett más írói stílust keres. Ír a korszak énelbeszélésen alapuló regénymüvészetéről, a pszichologizáló prousti, joyce-i irodalomról is. Azért igyekszik beláttatni, hogy még ehhez képest is új írói technikákra van szükség, mert a lélektani ábrázolás eredményét, az egyes szám első személyben, teljes valójában kitárulkozó szereplő regénybeli megjelenését is „látszatként” értékeli. ${ }^{105}$ Egész életmüvében tartózkodni fog a pszichologizáló attitüdtől, mert az érzelmeket, a kapcsolati kisugárzást megnevezhetősége, kibontakozása előtti, nonverbális állapotában kívánja megragadni. Hiába vallja, hogy olyan íróelődöktől tanult mint Proust, Joyce, Kafka, Dosztojevszkij, Virginia Wolf, akik mindnyájan a lélektani ábrázolás, a pszichológiai irányultság mesterei, és bármennyire is állítható lenne, hogy lélektani kutatásainak mélyrétegei, az emberről való reflexiója miatt akár a legnagyobb francia moralisták sorában is helye lehetne ${ }^{106}$, Sarraute szövegei távol állnak mindenfajta szubjektivizmustól és azt keresik, ami a psziché szintje alatt húzódik meg: a „mikropszichológiai univerzumot”, a minden emberi dolgok kezdetének csodáját. ${ }^{107}$

Mindennek van egy írástechnikai vetülete is: a szómögöttes szövegtípus soha nem lesz egyes szám első személyü, egyfajta idézett belső beszédnek, narrativizált monológnak tudnám nevezni. ${ }^{108}$ Azt, hogy a freudi pszichoanalízisről sincs pozitív véleménye, inkább mindennek következményeként tekintem. ${ }^{109}$ „Ahogyan Flaubert „,regénytelenítette” a regényt, úgy

${ }^{104}$ Moutote, Daniel (1998). Le journal de Gide et les problemes du moi (1889-1925), Geneve, Slatkine Reprints, p. 40. Elérhető: https://books.google.hu/books,Moutote,Daniel.Le+journal+de+Gide+et+les+problemes+du+moi.html (Letöltés ideje: 2019. 07. 02.) idézi Gide naplóját : „Il semble décidément que ce soit l'intensité de vie qui s’y trouve, qui fasse la valeur d'une chose. Que cette vie, d'ailleurs, soit celle de l'artiste ou celle du sujet représenté."

${ }^{105}$ N. Sarraute (1956). p. 71. apparence

106 Tison-Braun (1971). p. 10.

${ }^{107}$ U.o. p. 12. „univers micropsychologique”, „miracle des commencements”

108 monologue intérieur narrativisé

109 Sarraute, Nathalie (1953). "Interjú Gabriel d'Aubarèddel", Les Nouvelles littéraires in Sarraute (1996). Euvres completes, p. 4. „Mindig dühített a pszichoanalízis. Az a véleményem, hogy sokkal inkább belső világunk elkendőzésén munkálkodik, mintsem felszínre hozatalán.” / „La psychanalyse m’a toujours agacée. Je crois qu'elle masque beaucoup plus le monde intérieur qu'elle ne le révèle".

Sarraute, Nathalie (1983). "Interjú François-Marie Banier-val", Le Monde des livres in N. Sarraute (1996). Oeuvres completes, 1996. p. 2076. „Freud életmüve nem tudományos jellegü, inkább hiedelemről van szó, a 
demisztifikálja Sarraute a tudatalattit." ${ }^{110}$ A fentiek függvényében kijelenthető, hogy Sarraute nem mond le olvasó és szöveg találkozásának hitelességéről, számára ez az autentikusság, ha nem is elvárás, de létezhető valóság.

A kognitív pszichológia jelen állása szerint sem léteznek az érzelmek, hanem a félelem, az öröm, az utálat nevű érzetek fogalmi értelemben, értelmezésként konsituálódnak. ${ }^{111} \mathrm{Az}$, hogy az érzelmek hogyan, milyen módon kitapinthatók az emberben, mindig is az irodalmi érdeklődés homlokterében állt. De csak a kognitív elméleteknek köszönhető annak felismerése, hogy az érzelmek valójában érzetek, amelyeknek csupán utólag adunk neveket azok interpretációja során. A filozófiatörténet során egyébként az érzelmek fogalmi megragadása mindig problematikus volt. „Az arisztotelészi pathosz a léleknek valamiféle mozgékony, mozgalmas, változékony állapotára utal"112. Idézem Simon Attilát, aki az arisztotelészi pathosz fogalmát körüljárva az érzelmeket a mozgékonyság, a változás, a változékonyság, az erkölcsöket pedig az állandóság kategóriáival ragadja meg. Descartes ${ }^{113}$ szintén tisztán megkülönbözteti az érzelmek testi és a lelki vonatkozásait. A test gép, gépezet, amelyben az állati tudat és az idegek működnek. Szerinte a lélek elsődleges szerepe a gondolatok elkülönítése kétféle szerepkör szerint: a lélek cselekedeteit jelentő akaratra és a szenvedélyekre. „,...) Minden olyan érzékelést vagy ismeretet általában szenvedélynek nevezhetünk, amely bennünk található, és amely abból ered, ahogyan (a lélek) befogadja és értelmezi a dolgokat." ${ }^{114}$ Tehát már Arisztotelésznél megjelenik, hogy az érzelmek megragadhatatlan, hullámzó érzetek, amelyeknek a mederbe terelését az erkölcs vállalja magára, s később Descartes is felveti csak más kontextusban, hogy a szenvedélyek, azaz az érzelmek valójában bizonyos testi érzékelések tudati értelmezései. Az érzések

hívőkkel pedig nem lehet hittételeikről vitatkozni” / „L'œuvre de Freud n'a rien d'une science, il s'agit d'une croyance, on ne peut pas discuter avec les croyants leurs actes de foi."

Deleuze egyenesen tudományosan kártékonynak tartja a pszichoanalízist. Deleuze, Parnet (2016). Párbeszédek. L’Harmattan, ford. Karácsonyi Judit, Lipták-Pikó Judit, Gyimesi Timea Halott pszichoanalízis analizáljatok c. fejezet p. 66-67. „Nem rendelkezünk a tudattalannal, nincs meg, soha nem is volt, a tudattalan nem ,az”, ahova aztán az „Énnek” el kell jutnia.” „A pszichoanalízis teljes egészében arra szolgál, hogy megakadályozza az embert a beszédben, és megvonja tőle az igaz megnyilatkozás minden feltételét."

110 Tison-Braun (1971). p. 24. "omme Flaubert avait déromantisé le roman, elle démystifie l'inconscient."

${ }^{111}$ Rom Harré (1994). Erzelem és emlékezet: a második kognitív forradalom Emotion and Memory: The Second Cognitive Revolution. Kézirat. A tanulmány a Collegium Budapest meghívására 1994. május 30-án The second cognitive revolution címmel elhangzott előadás módosított változata. Elérhető: http://www.c3.hu/scripta/replika/25/harre.htm Letöltés ideje: 2019. 12. 09.

112 Simon Attila (2014). "Affekció és ítélet. Arisztotelész Retorikájának pathosz-fogalmáról" in Szenvedély, szerelem, narrációk. Filozófiai és pszichológiai tanulmányok, szerk. Boros Gábor, Pólya Tibor, Budapest, Eötvös Kiadó p. 15.

${ }^{113}$ Descartes, René, Les passions de l'âme. Elérhető: https://www.les-philosophes.fr/penseurs/les-passions-delame.html Letöltés ideje: 2019. 12. 09.

${ }^{114}$ Uo. "(...) on peut généralement nommer ses passions toutes les sortes de perceptions ou connaissances qui se trouvent en nous... (et que notre âme) ... reçoit toujours des choses qui sont représentées par elles." 
reprezentativitásának és a szépirodalmi alkotás mechanizmusainak egymásba fonódása a szépirodalmi alkotásban pedig már Arisztotelész és a mimézis elvétől kezdve hagyományos tendencia.

Az énelbeszélés ${ }^{115}$ eljárásait meghaladó irodalmi beszédmódok segítségével Nathalie Sarraute is a fiktivitás keretein belül maradva a lélek mélyét kívánja láttatni. A tropizmusok nem érzelmek vagy érzelmek interpretációi, hanem „,belső történések”116, amelyekre a mozgékonyság, a meghatározhatatlanság, és a szavakkal való kifejezhetetlenség jellemző. Ködből épülnek szavakká, ezért is a dadogó stílusforma, amely tudatos ellentétet képez a beszédünkben definiálódó, fogalmi formát öltő, átéltnek hitt érzelmekkel szemben ${ }^{117}$. Ugyanis a mentális folyamatok lenyomata nem rögzülhet mimetikusan - Deleuze a festészetben az „erők megmutatását” helyezte előtérbe a „formák reprezentációjához” ${ }^{118}$ képest. Sarraute is a hétköznapi gesztusokra redukált narrativitás mögé rejtve bontja ki a szómögöttes tartalmakat, a szavakba nem önthető érzeteket, a „kezdet csodáját"119.

„Ami engem érdekel, az a szereplőben létrejövő láthatatlan tropizmusok bemutatása, amelyeknek hatására cselekszik és amelyeknek ő maga nélkülözhetetlen foglalata." ${ }^{120}$ Amikor ezeket az állapotsorozatok foglalataként bemutatott tropizmus-testesüléseket ${ }^{121}$ az olvasók és a kritikusok elé tárta, azzal szembesült, hogy valódi, tulajdonságokkal felruházott személyeket kerestek bennük és nagy érzelmeket: féltékenységet, szerelmet, nagylelküséget, zsugoriságot. Pedig az írónő alapállása ettől egészen eltérő:

\begin{abstract}
„Számomra ma már az egyetlen élet a világ ismeretlen rétegeinek az új valósága, amelyet az olvasó is felfedezhet annak az erőfeszítésnek az árán, amellyel megtanul elhatárolódni minden tudatában felhalmozódott látszatvalóságtól, konvencionális érzés- és látásmódtól."."22 Mindenképpen távol tartja magát a szereplők testi-lelki világának szövegszerủ megidézésétől, azonban vallja, hogy tropizmusaival „mentális univerzumot alkot”"123.
\end{abstract}

Ebben a foglalat-szereplő által hordozott tropizmusuniverzumban egyesülhet újra a gyanakvást átélt szerző és olvasó, akit szinte „kényszerít, hogy merüljön e láthatatlan drámák

\footnotetext{
115 Cohn (1981).

116 ,actions intérieurs”

117 „nous croyons éprouver”

118 Deleuze (2014). „,forces en peinture” „représentation des formes”

119 Tison-Braun (1971). ,miracle du commencement”

120 Sarraute, Nathalie (1996). "Roman et réalité" in Euvres complètes, p. 1653. "Ce qui m’intéresse, c'est de montrer les tropismes invisibles qui se produisent dans le personnage, qui le font agir, dont il est l'indispensable support."

${ }^{121}$ Uo. personnages-supports, porteurs d'états

122 Uo. p. 1654. „Non, la seule vie pour moi, aujourd'hui, c'est celle de cette réalité nouvelle, d'un aspect inconnu du monde, que le lecteur, par un effort qui lui fait rejeter toutes les manières de voir, de sentir conventionnelles, apprises, tous les trompe-l'oeil dont sa conscience est remplie, peut découvrir á son tour."

123 Sarraute, Nathalie (1996). "La Littérature, aujourd'hui" in Euvres complètes, p. 1659. "la création d'un univers mental"
} 
mélyére, még mielőtt tudná, hol van" ${ }^{124}$. Mindez arra utal, hogy a szereplő megalkotottsága és értelmezhetősége is elszakad a szavakkal kifejezhető testi-lelki realitásoktól és a szavak, érzelmek, döntések, sorsok, történetek mögötti személytelenségben való egymásra találást célozza $^{125}$. Ez a típusú olvasási folyamat fizikai valóságunk már-már növényi, állati, gondolat, érzelem, szavak előtti állapotába repít, melyben a szereplök funkciója a tropizmus szöveggé írhatósága.

A klasszikus narrativitástól való eltávolodás poétikája ugyanakkor beleillik a kor irodalomelméleti környezetébe. Az Irodalom, $m a^{126}$ című interjúban az interjú készítője felteszi Sarraute-nak a kérdést, hogy mennyiben kapcsolódik az Új Regény irodalmi irányzathoz. Sarraute válaszának lényege a klasszikus narrációs technikáktól való tudatos elhatárolódásra, eltávolodásra való utalás mint az írókortársakkal való közös platform.

„Ha a hagyományos regény formai megoldásainak tagadása, (...), ha a fogalmilag megragadható érzelmek, a szereplők, a jellemek, a nevek hiánya, (...), ha egy azonos jelenet új és új nézőpontból való megjelenítése (Martereau, 1953.), ha az időkezelés, a párbeszédesség sajátos eljárásai (...) nincsenek kapcsolatban az Új Regénnyel, akkor semmi közöm hozzá."127

Nathalie Sarraute regénymüvészetében tehát a klasszikus narratív technikákkal, többek között a szereplő megalkotottságával szembeni gyanakvás megoldásaként az ezektől való elhatárolódás mint írói eljárás, és a tropizmussal való már-már egzisztenciális egyesülés elvárása jelenik meg. Ennek célja, hogy az olvasó és a szöveg találkozását eltávolítsa a hagyományos befogadói rutintól, hogy már-már a delírium bűvkörében tudjon csak megvalósulni. Sarraute tropizmusainak esetében tehát semmilyen olvasói hozzáállás, interpretációs technika nem válthatja ki a befogadás teljes vágyát, motivációra éhes szabadságát, mert a kritikai attitűd, az önálló gondolkodás, a külső megfigyelés lehetősége ki van zárva, az értelmezés ismert formái elenyésznek a meg nem nevezhető érzelmek, tisztázatlan kapcsolati folyamatok, dadogó leírások, azonosíthatatlan szereplők hálójában.

Az alkotásban a szociális környezet, a való világ részben vagy egészben kiiktatódik, hogy átadja a helyét a „,bensőleg átélt mozgássoroknak” és a „nyelv titkainak” ${ }^{128}$. A lélektani

\footnotetext{
${ }^{124}$ Sarraute, Nathalie (1996). "Roman et réalité" in Euvres complètes p. 1654. „en l'obligeant á plonger au coeur des drames invisible, avant de savoir où il est."

${ }^{125}$ Deleuze-Parnet (2016). p. 45. „Az igazat megvallva, az írás célja nem önmagában rejlik, pont azért, mert az élet nem valami személyes dolog. Az írás célja inkább abban rejlik, hogy az életet a nem személyes erő állapotába emelje. Ezzel lemond minden territóriumról, minden olyan célról, mely esetleg önmagában rejlik."

${ }^{126}$ Sarraute, Nathalie (1996). "La Littérature, aujourd'hui" in Euvres complètes, p. 1656.

127 Sarraute, Nathalie (1996). "La Littérature, aujourd'hui" in Euvres complètes p. 1656-1657. „Si la négation radicale des formes du roman traditionnel, (...), si l'absence de sentiments définissables, de personnages, de caractères et de noms propres (...) si la reprise sous des angles différents d'une scène identique (Martereau, 1952.), si une certaine façon de traiter le temps dans le roman, de se servir du dialogue (...) n’a rien á voir avec ce qu'on nomme aujourd'hui le nouveau roman, alors je n'ai rien á voir avec lui."

128 Tadier (1984). p. 57. „mouvements intérieurs”, „secrets du langage”
} 
mozzanatot Sarraute úgy kívánta beépíteni a szereplö-alak körberajzolásába, hogy annak személyes indíttatása ne kizárólagos legyen, hanem az olvasó mindig implikálódhasson. Így a befogadó nem érzelmileg kezd kötődni a hőshöz, annak pozitív vagy negatív, esetleg típus jellege miatt, hanem a tropizmus hullámára való ráhagyatkozás segítségével az alkotás mélységeivel egyenértékü érzetkötegek szintjén már-már azonosulhat az alkotói létállapottal. Ezért a klasszikus befogadói attitüdtől eltérő olvasási módokra van szüksége.

\section{III.3. A szereplő értelmezése a strukturalizmus égisze alatt}

A már említett Lucien Goldmann teoretikus munkái kivételt képeznek az 1960-as években, amikor a szövegimmanens elméletek, azaz a strukturalizmus nyert teret Barthes, Todorov vagy a narratológia területén Genette munkásságával. Már Saussure nyelvelméletében megjelenik az önkényes nyelvi jel elgondolása, a strukturalisták pedig erre alapozzák a nyelvi jelek és a valóság szétválasztását, a reprezentáció új formáit ${ }^{129}$. Ebben az értelemben az irodalmi szövegnek nem a szemantikája, hanem a szintaxisa válik hangsúlyossá az értelmezéskor, és átformálódik az az klasszikus alapvetés is, hogy az irodalmi szöveg jelölői számára a valóságban kellene jelöltet keresni. Jakobsonnak ${ }^{130}$ az esztétikai célú szövegek esetében érvényesülő poétikai funkciója is a hangsúlyt az üzenetre helyezi, annak autotelikusságát, autoreferencialitását emelve ki. Ezek a strukturalista elméletek meghatározzák az 1970-es éveket.

A Valéry által „papírlénynek"131 nevezett szereplőket a strukturalizmus funkcionalitásukban vizsgálja. Akárcsak a gyanakvás korszakában formálódó Új Regény, amely elhatárolja magát a „mély karakterrel” rendelkező szereplő felléptetésétől és egy „kártyajátszma lapos figuráinak” titulálja őket ${ }^{132}$. E gondolat tekintetében az Új Regény és a strukturalizmus nem áll messze egymástól, hiszen mindkettő alapja egyfajta fenomenológiai szemlélet. A fikciós világ megszerkesztett, önkényes, jelekböl áll, e jelek közül egy az immanensnek tekintett szereplő, amelyet actantnak, cselekvőnek nevez és a többi szöveg további építőkövei viszonylatában funkcionalitásában nyer értelmet. A strukturalista megközelítés a szereplőt az irodalmi szöveg nyelvi valóságát létrehozó jelek közül egynek,

\footnotetext{
${ }^{129}$ Compagnon (1998). p. 105.

130 Jakobson (1982).

${ }^{131}$ Valéry, Paul (1957). Cuvres complètes I-II. Paris, Gallimard p. 1340-1358. "être de papier"

132 Milat Christian (2006). "Robbe-Grillet, Prométhée et Sisyphe écrivains" in Hamel, Yan, Bouchard, Mawy (dir.), Portrait de l'homme de lettres en héros, Elérhetö: file://C:/Users/lomba/Downloads/440Texte\%20de\%20l'article-604-1-10-20120801.pdf Letöltés ideje: 2019. 07. 15. idézi Robbe-Grillet kifejezését
} 
egy jelekből álló modell egyik elemének tételezi ${ }^{133}$. Ricardou szerint írni azt jelenti ,az irodalmi produktivitásnak" megfelelően, hogy mint egy különleges tér lehetőségeit, úgy aknázzuk ki a nyelv kínálta utakat ${ }^{134}$. Ezek az említett irodalmi funkciók nem állnak messze a strukturalizmus Benveniste-et, Jakobsont, Saussure-t idéző, barthes-i, kristevai ${ }^{135}$ vonulatával.

A fenti új irodalmiság-elméletek nem feleltethetők meg Genette elgondolásának, aki szeretné újragondolni az irodalmi mű klasszikus definícióját, de sarkaiból nem fordítaná ki a hagyományos elméleteket. Sőt, tagadja is az írás intranzitivátását:

„Minden diskurzus tárgyra irányul, akár konkrét ez a tárgy (dolgok, cselekmény, szereplők, környezet), akár elvont (gondolatok, társadalmi valóság, isteni kegyelem), de lehet ez a tárgy maga is egy adott szöveg, azaz (ahogy Proust megjegyzi) 'gondolati dolog, amely ugyanakkor nem elvont', hiszen egy adott, egy bizonyos"136.

A francia struktrualista irodalomelmélet a szövegek szemantikája helyett a diskurzusok szintaxisa, tehát szerkezeti felépítése felé fordult az értelmezés során. Algirdas Julien Greimas és Paul Ricoeur voltak azok, akik arra törekedtek, hogy visszatereljék az irodalomértelmezést a szemantika felé, tehát egyfajta világértelmezésben is helytálló jelentést tulajdonítsanak a szövegeknek. Greimas használja a strukturalista elméletírók nyelvezetét, de elhatárolódik a kizárólag strukturalista irodalomtudománytól és Strukturális szemantika ${ }^{137}$ című művében fejti ki szereplőértelmezését. Ezzel az elmélettel nagyban hozzájárul a narratológia továbbfejlődéséhez.

Greimas elgondolása szerint egy szöveg jelentésessége elsősorban a benne megjelenő izotópiáknak, azaz nyelvtani és jelentéstani ismétlődéseknek köszönhető, ezek tartják össze a mondanivalót. Ez érvényesülhet a köznyelvi szövegekben éppen úgy, mint szépirodalmi stílusúakban, hiszen olyan stilisztikai jelenségeket is az izotópia fogalmával magyaráz, mint a metaforizáció ${ }^{138}$. A.-J. Greimas az izotópia fogalmáról: „Azoknak a redundáns kategóriáknak az összessége, amelyek lehetővé teszik a történet egységes olvasatát."139 Az izotópiák

\footnotetext{
133 Todorov, Tzvetan (1971). "Les hommes-récits" in Poétique de la prose, Paris, Seuil, p. 78-91.

${ }^{134}$ Viart (1993). p. 120. ,production littéraire” - irodalmi 'produkció', azaz létrehozás (Kristeva)

Deleuze, Párbeszédek p. 9. „écrire, c'est ce projet d'explorer le langage comme un espace particulier” A geofilozófiát és Deleuze szökésvonalait idéző szavak. Az arcot adó nyelvtől a szépirodalmi nyelv nyelv szökésvonalakon szabadul el.

135 Viart (1993). p. 120.

136 Genette (1991). Fiction et diction, p. 135. „...tout discours porte sur un objet, que cet objet soit concret (choses, actions, personnages, paysages...), abstrait (les Idées, l'humaine condition, la grâce divine...) ou luimême un texte singulier, c'est-à-dire (comme dit Proust à propos d'autre chose) un objet 'idéal sans être abstrait', puisque singulier."

${ }^{137}$ Algirdas Julien Greimas (1966). Sémantique structurale. Paris: Larousse.

${ }^{138}$ Greimas, Courtès (1979). Sémiotique. Dictionnaire raisonné de la théorie du langage (Langue, Linguistique, Communication) Paris: Classiques Hachette

${ }^{139}$ Greimas (2012). Du sens, Paris, Seuil, p. 188. "Un ensemble redondant de catégories sémantiques qui rend possible la lecture uniforme du récit"
} 
lehetnek mennyiségi szempontúak (hányszor bukkan fel a szereplő), minőségiek (milyennek állítják be, milyennek mutatják be, pl. mindig mérges vagy egyszer mérges, egyszer kedves), illetve funkcionális szempontúak (hogyan befolyásolja a cselekményt). A korban divatos szubjektivizáló, a szövegeket autotelikus valóságoknak beállító irodalomelméletekkel szemben a geimas-i teória didaktikusabbnak, ha tetszik tudományosan jobban alátámasztottnak tetszett, s így követőkre talált ${ }^{140}$.

Propp $^{141}$ és Lévi-Strauss ${ }^{142}$ mese- és mítoszelméleteire reflektálva Greimas megkísérli a narratív szövegek szereplő szempontú globális mélystruktúrájának meghatározását. Propp szereplőtípusait és az általuk betöltött funkciókat igyekszik továbbgondolni, tökéletesíteni. Legfőképpen rendszerbe helyezi Propp szereplőit és funkcióit és nagy mértékben csökkenti az általa megnevezett hősök számát. Mind a két elméletíró, Propp és Greimas gondolatkörében is nagy szerepe van a hős és a cselekmény kapcsolatának, azaz nem önmagában vizsgálják a szereplő jellemét és funkcióját, hanem a szöveg többi mozzanatával, tehát a témával, a cselekmény alakulásával vagy az időfaktorral összefüggésben. Mindig az a gondolat húzódik meg emögött, hogy az irodalmi szöveg, és ezen belül a narratíva és a narratíva részei, úgy mint helyszín, a cselekvő, az idő nem ,papírízűek”, hanem mindig jelentésesek, mindig ,jók valamire", mindig továbbgondolhatók. Nem lehet őket önmagukban szemlélni, csak egy rendszer részeként.

\footnotetext{
140 Dirk de Geest (2003). La sémiotique narrative de A.J. Greimas Elérhető: http://www.imageandnarrative.be/inarchive/uncanny/dirkdegeest.htm (Letöltés ideje: 2019. 07. 08.) ${ }^{141}$ Vlagyimir Jakovlevics Propp (2005). A mese morfológiája, Bp., Osiris

142 Claude Lévi-Strauss (1958). Anthropologie structurale. Paris: Plon.
} 


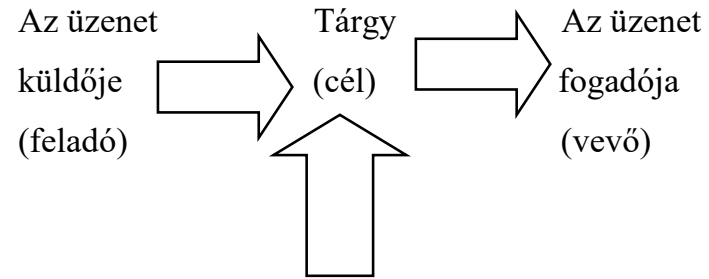

Keresés (vágy)

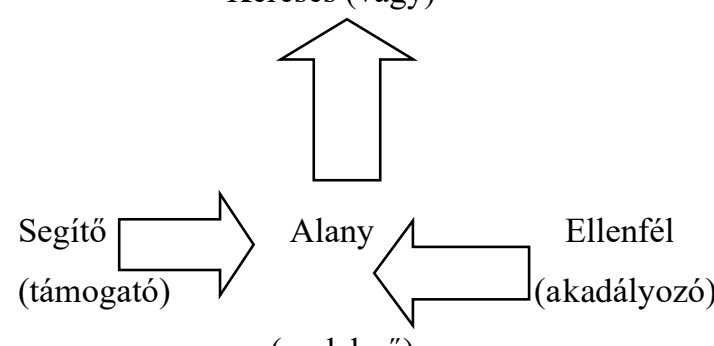

(cselekvő)

Greimas modellje a cselekvő, a cselekmény, a szerző és a befogadó viszonyának leírására.

A nyilak mentén a modell három fötengelyre oszlik. Az első a cselekvőt ${ }^{143}$ és célját összekötő tengely (a keresés, a vágy tengelye). A cselekmény dinamikája szinte mindig a cselekvő hiányérzetéből és annak betöltési kísérletéből fakad (szeretne megkapni valamely anyagi vagy szellemi javat, amelynek nincs birtokában). A második tengely a harc, a küzdelem tengelye, hiszen útján segítője és hátráltatója is van. A feladó és a vevő funkcióinak beépítésével létrejön a harmadik tengely, $\mathrm{s}$ ezzel a teljes modellt kommunikációelméleti sémába helyezi a szerző.

A fenti sémát modellszerüsége, rendszerszerü felépítettsége közelíti kortársai szintaktikus, nyelvelméletekhez kapcsolódó irodalomelméleti megközelítéseihez, ugyanakkor ideológiája az, hogy a szöveg nem öncélú, hanem ebből valaki profitál, az értelmezéssel a befogadó maga is előrébb jut az életében, de legalábbis „kommunikál” a szerzővel. A modell egészén belül megfigyelhető az egymáshoz való viszonyulás, a cél- és értékképzés mozzanata, amely szembeállítja a szöveg autelikusságát hirdető elméletekkel. Felhívom még a figyelmet a Greimas által használt fogalomra: a funkcionalitásában szemlélt, kontextualizált actant, cselekvő fogalmát használja a „papírízü” szereplő vagy hős helyett. Szóhasználatának értelmezése lehet, hogy itt szemantikailag értett szerepekröl van szó, amelyek némiképp „üresek”, „betölthetők”, a diskurzus kontextusában variálhatók. A cselekvő összetett, többszereplős folyamat részese, személyének és viselkedésének elemzése a cselekmény értelmezési keretében érvényes, s mint ilyen, összefüggéseiben modellált.

Az 1960-as évek végén, az 1970-es évek strukturalista, illetve narratológiai megközelítése úgy fejlesztette tovább az elbeszélésmódok tudományos vizsgálatát, hogy felhagytak a pszichológiai terminusok használatával, és nem létezőként definiálták a szereplöt, tehát nem személyként, hanem a nyelvészeti alapú megközelítésnek köszönhetően résztvevőként.

\footnotetext{
143 actant, modèle actantiel
} 


\section{III.4. A szereplő értelmezése az 1970-es évektől}

Philippe Hamon 1972-ben íródott Pour un statut sémiologique du personnage [A szereplö szemiológiai megközelitése] adja meg az 1970-es évek alaphangját. ${ }^{144}$ A szereplőt jelként fogja fel és a szöveg egyik szerkezeti részeként, ilyen értelemben a strukturalista elméletet viszi tovább. Akárcsak Greimas, ő is igyekszik a jelentésességet beépíteni a rendszerébe úgy, hogy intratextuális kontextuson túlmutató jelentésrétegeket kapcsol a szereplő-jelhez. A regény kezdetekor üres jeltárgy, amelynek jelentése az olvasás végére rögzül a rárakódó ismeretek, a kapcsolatok alakulása és a formálódás révén. Hamon rendszerétől nem idegen a kulturális kódok beemelése sem, a történelmi, társadalmi ismereteink meghatározzák a szereplő-jel percepcióját.

Benveniste $^{145}$ a jelentésképzés két módját különbözteti meg: az egyiket, ami a jelek (szemiotika), a másikat, a diskurzus sajátossága (szemantika). Ezt továbbgondolva Hamon szerint akkor képezheti valamely jelenség szemiológiai vizsgálat tárgyát, ha tudatos kommunikációs folyamat része, jeleknek (lexika) kis számú (véges) megkülönböztető jegyeit hordozza és összerendeződésüket és egységbe szerveződésüket kis számú meghatározott (véges számú) szabály határozza meg (szintaxis) függetlenül a létrehozott vagy létrehozó üzenetek végtelen számától. Ahogyan a nyelvészet a fentiek szerint vizsgálja a nyelvi jeleket, lebontja a végtelen számú nyelvi jelet véges számú fonémára, morfémára, szintagmára, ugyanúgy a diskurzuselemzés körébe sorolt szereplővizsgálatok is szükítik az értelmezésbe bevont elemek számát (szövegegység, narratív egység, szöveg, cselekvő). ${ }^{146}$

Már Benveniste is foglalkozott a jelentésadás rendszerével az irodalmi szövegekben:

„Megkülönböztethetünk jelentéshordozó rendszereket, amelyeket az író ért bele szövegébe, más jelentésképző folyamatokat a szöveg alapelemei bontanak ki mintegy izoláltan, függetlenül bennük összekapcsolódó viszonyoktól. Az első esetben a jelentésképzés egy zárt világ szerveződéséből bontakozik ki, a második esetben pedig a jelen belül marad."147

Hamon szerint az irodalmi szöveg tehát többszörösen kódolt: egy a nyelvhasználati módok közül, müalkotás és az irodalom része.

\footnotetext{
${ }^{144}$ Hamon Philippe (1972). "Pour un statut sémiologique du personnage" in Littérature, n ${ }^{\circ}$, p. 86-110; Elérhető: https://www.persee.fr/doc/litt_0047-4800_1972_num_6_2_1957, Letöltés ideje: 2019. 07. 17.

145 Benveniste E. (1969). "Sémiologie de la langue" in Semiotica, Mouton, La Haye

146 séquence, syntagme narratif, texte, actant

${ }^{147}$ Benveniste in Todorov, Tzvetan (1965). Théorie de la littérature p. 28. "On peut distinguer les systèmes où la signifiance est imprimée par l'auteur à l'œuvre, et les systèmes où la signifiance est exprimée par les éléments premiers à l'état isolé, indépendamment des liaisons qu'ils peuvent contracter. Dans les premiers, la signiflance se dégage des relations qui organisent un monde clos, dans les seconds elle est inhérente aux signes eux-mêmes."
} 
Hamon rendszerével megismerkedve két fontos eredményére lehetünk figyelmesek. Egyrészt gazdagon használja, cizellálja és gondolja tovább a strukturalista irodalomelmélet és a narratológia szókincsét, terminusait, s ezzel sajátos gondolatrendszert hoz létre. Például „szereplő-jel”148 - Napóleon a lexikonban; ez elkülönül a „nem irodalmi szövegszereplőtől”149 - valamennyi, a történelmi személyiséget helyettesítő szó vagy szófordulat nem irodalmi szövegekben, illetve „,irodalmi szöveg-szereplö" ${ }^{150}$ - ez ugyanő a Háború és békében. A terminusok rendszerének árnyaltabbá tétele mellett érdeme, hogy felhívja a figyelmet a szereplők közötti különbségtétel stilisztikai vonatkozásaira. A hős, az áruló vagy az ál-hős ${ }^{151}$ szövegbeli funkciók, melyeknek elkülönítése alapvetően Hamon szerint stilisztikai eljárásokkal lehetséges. Kizárólag hangsúlyokon múlik megkülönböztetésük, s ezeket a szövegtónusokat az író, illetve az olvasó által megismert előzetes kulturális kódok determinálják. A szereplő funkcionális, illetve stilisztikai szempontú vizsgálata tehát szerinte nem is mindig elkülöníthető.

Összefoglalóan Hamonnak a szereplő meghatározására tett kísérlete tartalmazza először is a nem állandó, tehát változásban lévő jelölö-alak szövegszerü megjelenésének formáit, stilisztikai rendszerét, az azt helyettesítő nyelvi elemeket. Másodszor a szintén nem állandó, változásban lévő jelölt-alakot, amely többrétegü szemantikai jellegzetességek hordozója. Harmadsorban a szereplő-jel kapcsolatainak jellegét, alakulását, típusait (aktánsok), amelyek a greimasi rendszerhez hasonlóan zárt, elvont paradigmát alkotnak (Alany, Tárgy, Vevő, Feladó, Segítő, Ellenfél). A hamoni rendszer lényege a greimasihoz hasonló, tehát a cselekmény alakulásában és a szereplők felépítésében meghatározó megkülönböztető jegyek feltárására törekszik, csak továbbfejleszti azt.

Vincent Jouve ${ }^{152}$ a recepcióelmélet szempontjából vizsgálja a szereplőt. Azt fejti ki, hogy az olvasónak, az olvasásnak, az olvashatóságnak milyen szerepe van a szereplő alakjának felépítettségében, mi a szereplő helye, melyek értelmezési lehetőségei az olvasási folyamat során. Pour une analyse de l'effet-personnage $[A$ szereplö olvasói hatásvizsgálata $]^{153}$ című művében azt elemzi, hogy egy-egy szereplő értelmezése nem függ-e minden egyes olvasás olvasójának személyétől? Innen a pszichológiából az

\footnotetext{
148 ,personnage-signe”

149 „personnage-en-énoncé non littéraire”

150 „personnage-en-énoncé littéraire”

${ }^{151}$ Propp terminusai

152 Vincent Jouve (1992). "Pour une analyse de l'effet-personnage" in Littérature, n85, 1992. p. 103-111; Elérhető : https://doi.org/10.3406/litt.1992.2607 ; $\quad$ https://www.persee.fr/doc/litt_0047800_1992_num_85_1_2607 Letöltés ideje: 2019.07. 20.

153 U.o.
} 
irodalomelméletbe érkező interszubjektivitás fogalma: a befogadás individualitása, egyéni volta, amelyet azért meghatároz a szöveg szerkezete, felépítése. A szöveg mindig implikál valamiféle, szövetébe, szerkezetébe beleértett befogadót, akinek a meghatározására G. Prince, Genette-re építve a történetkülső befogadó ${ }^{154}$ fogalmat használja. Szerepe, hogy kommunikációs kapcsolatot létesítsen a valóságos olvasóval ${ }^{155}$.

Az immanens megközelítés tehát, bármilyen produktívnak tünik számos tudós vagy müvész számára, akik az alkotói módszereket helyezik előtérbe, máris nem érvényesíthető, ha a müalkotást kommunikációelméleti szempontból értelmezzük. Az irodalmi szövegek olvashatósága minimális követelményként támaszt valamiféle referenciális minimumot. Ducrot és Todorov enciklopédiájában a Szereplő címü szócikk ${ }^{156}$ világosan tartalmazza, hogy bár a szereplő nem értelmezhető élő személyként, valamiféle személy-szereplő kapcsolatnak lennie kell, különben a szöveg abszurd. Barthes, Effet de réel [Valóság-hatás] címủ esszéjében beszél a témáról. Catherine Kerbrat-Orecchioni megadja a kegyelemdöfést az autoreprezentációs irodalmi szöveg mítoszának: „Minden szöveg utalásrendszer, azaz egy olyan világra nyit ablakot, amely már ismert, vagy amelyet maga a szöveg hoz létre, és amelynek mibenléte nyelven kívüli"157. Összefoglalva Jouve kommunikációelméleti alapállásból teszi fel a kérdést: mit jelent a szereplő az író, illetve az olvasó számára. Szerinte a szöveg által létrehozott figurák az olvasás útján nyernek értelmet, hiszen az olvasó ad életet a münek. A szereplő funkcionális, formális leírása nem elegendő. Nem elég feltenni a kérdést, hogy mi a szereplö, az is érdekes, hogy mivé válik az olvasás során vagy továbbmenve: hogyan és mi célból fogja fel az olvasó?

Jouve elmélete azért érdekes Sarraute és az Új Regény értelmezése szempontjából, mert a virtuális befogadó, azaz az esztétikai hatások szövegbelső vevője lehetővé teszi a valódi olvasó mint bio-pszichológiai alany általános reakcióit, így egy ilyen értelmezés kitágítja a szokásos „szereplő” terminus magyarázhatóságát. A fogalom kiterjesztése elvont szereplőkre (hegeli Szellem, a kegyelem Mauriac vagy Bernanos müveiben) vagy tárgyakra (Butor, Robbe-Grillet), illetve növényekre, könyvekre, szavakra (Nathalie Sarraute) arra utal, hogy az Új Regény szerzői nem várnak az olvasók részéről mindig érzelmi választ az olvasottakra. Klasszikus szereplőn nagyrészt antropomorf figurákat értünk, akár legyenek

\footnotetext{
154 narrataire extradiégétique -

155 M. Ramond (1994). "Le déficit, l'excès, l'oubli" in Le Personnage en question actes De Université de Toulouse-Le Mirail, Séminaire d'études littéraires, Colloque, Presses Universitaires du Mirail - Toulouse, p. 141-151.

156 Ducrot-Todorov (1972).

${ }^{157}$ Kerbrat-Orecchioni (1982). "Le texte littéraire : non-référence, auto-référence, ou référence fictionnelle" in Texte, 1, Toronto, Trinity College, p. 28., 105
} 
földönkívüliek vagy emberi tulajdonságokkal felruházott állatok. Deleuze találóan „komoran farkasszemet néző jelentéssel telített szubjektumokról” beszél ${ }^{158}$. A jouve-i hatás-szereplő (effet-personnage) azoknak a kapcsolatoknak az összessége, amelyek az olvasót a történet szereplőihez kötik. A szereplő a nyelvi jel modelljét alapul véve szerveződik ebben az értelmezésben, egymásnak megfeleltethető elemekből álló rendszerként, amely arra szolgál, hogy a szöveg olvasható legyen.

\section{III.5. Az Új Regény és Nathalie Sarraute szereplőelmélete a korszak elméleteinek viszonylatában}

Greimas, Barthes vagy Hamon értelmezése abban hasonlít, hogy immanens létezőként tételezi a szereplőt, szövegszerüen tudatosítható jelként tekint rá. Az 1960-as évek francia formalista szereplőelmélete Alain Robbe-Grillet vagy Nathalie Sarraute írásai nyomán kapott ideológiai hátteret. A szereplő számukra nem más, mint szavak szövevénye, „valódi mélységek nélküli létező" ${ }^{159}$ Ontológiailag a szereplő létének értelmezése számukra a személytől való elkülönítésében rejlik - az ezzel azonosítható jelentéshez hívom be dolgozatomba vendégterminusként Deleuze arctalanítás fogalmát. Sarraute a klasszikus narratíva lebontásán fáradozva a szereplő dekonstrukciójára fókuszál elméleti írásaiban, gyakorlati szinten pedig a történetmesélés, a klasszikus narratíva helyett a szereplök szövegszintű felépítettségében is a stílusra, a beszédmódra helyezi a hangsúlyt.

A XX. századi irodalomelméleti hagyomány a szereplö ${ }^{160}$ terminus helyett, ha Greimas munkásságát nézzük, már az 1960-as években, de az 1980-as évektől mindenképpen más kifejezéseket keres ${ }^{161}$. A szóhasználat változik, de ez nem jelent feltétlenül szakítást az eredeti szereplő szó jelentésmezejével. Inkább arról van szó, hogy különféleképpen megkonstruált diskurzusok részeként, sokarcúan reprezentálódó szereplőkre kell az irodalomértelmezésnek reflektálnia és ezért olyan szót keres, amely sokkal kevesebb berögzült denotációval rendelkezik, poliszémiára fogékonyabb. Tehát nem állítom, hogy a szereplö kihalt, hanem azt állítom, hogy leendésben van, figura-leendésben, perszonaleendésben, és föleg az arctalanítás folyamatában.

\footnotetext{
158 Deleuze-Guattari (1980). Mille plateaux p. 205. „le morne face-à-face des subjectivités signifiantes”

${ }^{159}$ Barthes (1977). "Introduction à l'analyse structurale des récits" in R. Barthes és tsai, Poétique du récit, Paris, Seuil, Coll. Points „vivant sans entrailles”; A. Robbe-Grillet (1963). "Sur quelques notions périmées - le personnage" in Pour Un Nouveau Roman Paris, Gallimard p. 12. Sarraute (1941). Ce que je cherche à faire P. Valéry (1941). Tel Quel, Paris, Gallimard, p. 221.

160 personnage

161 Sermon, Julie (2018). Construction du personnage et dramaturgie du jeu en régime figural, Elérhető: in www.pourunatlasdesfigures.net, dir. Mathieu Bouvier, La Manufacture, Lausanne (He.so) Letöltés: 2019. 07. 08.)
} 
Egyes elméletírók eljutnak a „szereplő válságához”162, én inkább egy új beszédmód részének tekintem a módosulást, hiszen az irodalmi és a teoretikus szövegvilág szintén változik, módosulást hozva a többi elméleti szakszó tekintetében is. Nem a szereplő fogalma vált tabuvá a 60-as, 80-as évek irodalomértelmezői kontextusában, hanem minden olyan fogalom, amely a szövegen kívüli, szemantikus, nem szintaktikus összefüggéseket keresett. Márpedig a szereplő, de a figura is ilyen: pszichológiai, szociológiai, etikai vonatkozásai nélkül nehéz beszélni róla, és sokarcú, nem is szereplőről vagy figuráról kellene szólnunk, hanem figurális reprezentációk soráról.

A figuráció szintje és módja az Új Regény kapcsán sokrétegü, több összetevőből áll és a müvön kívüli világgal való kapcsolata problematikus. Az értelmezés során alkothatunk ezekből rendszereket, logikai, történeti, szemantikai, szemiológiai (nyelvi jelek) és kulturális szinteken, de a stilisztikai rendszerek, pl. a konnotatív kódok, nyelvtani elrendeződések vizsgálata lehet alkalmas az adott müben vagy életmüben megjelenő titok-manifesztáció, egyénített szemiológiai felépítmény valamelyes kibontására. Nyilvánvaló, hogy stilisztikai módozatok segítségével való figuráción nem feltétlenül az adott téma antropomorfizációját, hősben való megtestesülését érthetjük.

„Ilyen értelemben létezne genetikai narratológia, amely szerint a nyelvhasználat önmagában hordozza legalacsonyabb nyelvi szintjeitől (szókincs, nyelvtani szerkezetek) egészen a használatban érvényesülö paradigmatikus nyelvi szintekig (állandó szószerkezetek, klisék, sztereotípiák, hétköznapi metaforika) minden lehetséges, kibontakozható cselekmény magját, implicit sugalmakat, amelyek az értelem diszkurzív megformálását előlegzik és olyan antropomorfizációkat, amelyek elöremutatnak a fikcióban megszülető szereplökre"163.

A figura főnév jelentése kis tárgy, alak, megjelenített látvány vagy látható végrehajtási forma $^{164}$. Eredete a latin figura, alak, forma szó, amely mögött a szanszkrit dheigh formáz, gyúr jelentés húzódik meg. A müalkotásokon ábrázolt valóságelemeket is ezzel a szóval fejezzük ki, de már régóta a szereplö, a hős szinonimája. A figura egyfajta szimbolikus szubjektum-megjelenítés a játék kontextusában, a koreográfiában a táncosok által reprodukált formális mozdulatsor. Jelentése, bár sokrétü, mindenképpen tartalmazza az érzékszervekkel való megragadhatóság szemantikai mozzanatát, inkább, mint a szereplő terminus.

\footnotetext{
162 Abirached, Robert (1994). La Crise du personnage dans le théâtre moderne, Collection Tel ( $\left.\mathrm{n}^{\circ} 245\right)$, Gallimard

${ }^{163}$ Greimas, A-J (2012). "Les jeux des contraintes sémiotiques" in Du sens, p. 135. „Il y aurait toute une “ narratologie génétique » à constituer. Le langage porte en effet en lui, dans ses constituants les plus humbles (lexique, paradigmes grammaticaux...) ou les plus fossilisés par l'usage (la locution, le cliché, la métaphore usée...), les germes de tout récit possible, des suggestions implicites pour une articulation discursive du sens et pour des anthropomorphisations qui créeront des personnages."

164 https://wikiszotar.hu/ertelmezo-szotar/Figura (Letöltés ideje. 2019. 07. 08.)
} 
A figura képpé, emblémává válhat. Harpagonnak hívják a zsugori szereplőt, Alecestenek a mizantrópot. Ezeknek a „kikristályosodott”165 típusoknak a háta mögött mindig felsejlik egy árnyalak, egy idea, amelyből ezek a szereplők mintegy kibontakoznak. Ilyen értelemben ezek a szövegekben megjelenő plasztikus identitások felidézik a jelentésképzés teljes folyamatát és a figura szó stilisztikai vonatkozását ${ }^{166}$ úgy, hogy gondolati, érzelmi tényezők metaforáiként értelmezhetők. Ugyanakkor Sarraute-nál az lényeges, hogy a szereplő stilisztikai megalkotottsága tudatos távolságot tart az esztétikai célú kommunikáció illusztrálásával. A szövegben felsejlő alak, figura, arc dinamikus valóság, a leírás pillanatában még talán az írónak sincs, sem lehet konkrét terve vele, nem tőle függ, hanem attól, ami látható, hallható, mondható, a pulzáló élettel van kapcsolatban. A sarraute-i figura tehát elszakadóban van a szereplőtől, akit karakter jellemez, azaz személyiségét a valószerüség értelmezési keretein belüli egyénítés segítségével teszi a szerző a narráció részévé, és a perszónától is, amely maszkszerủen, az irodalmi szöveg művi kereteit tudatosan vállalva emblematikusan mutat fel antropomorf valóságot.

Drámai mikrokozmoszt hoz létre, amely az eltérés, a kettőközöttiség, a változatos, sokszínü artikulációk elegye, organikus valóságmodellt kíván létrehozni, spontán, élettel teli kimerevített pillanatot. Deleuze az Alakról beszél ${ }^{167}$ Francis Bacon festői életműve kapcsán és az Alakot a figurativitással állítja szembe:

\begin{abstract}
„Bacon gyakran elmondja: azért, hogy elhárítsuk a figuratív, illusztratív, narratív jelleget, amellyel az Alak szükségszerüen rendelkezne, ha nem lenne elkülönítve. A festészetnek nem szabad sem modellt ábrázolnia, sem történetet mesélnie. S innentől kezdve két lehetséges út nyílik a figuratívtól való megszabadulásra: a tiszta forma felé az absztrahálás révén; vagy a tiszta figurális felé a kiemelés vagy elkülönítés révén. Ha a festő ragaszkodik az Alakhoz, ha a második útra lép, ezt azért teszi tehát, hogy szembeállítsa a „figurálist" a figuratívval” 168
\end{abstract}

Az a különös, hogy a Sarraute-szövegben megjelenített alak mégsem szereplö, karakter vagy bábu, azaz egyetlen klasszikus vonás sem sejlik fel vele kapcsolatban, amely a hagyományos narratíva szereplőjével tenné hasonlatossá: nincs jelleme, céljai, nem írható le egységes külső-belső vonásokkal, nem racionális. Ennek oka, hogy ha csak dadogó módban, de az író a szómögöttes kitárulkozással folyamatos sejtés-érzetben tartja az olvasót, stilisztikai

\footnotetext{
165 Sermon (2018) Abirached terminusa

166 Encyclopédia Universalis Elérhető: https://www.universalis.fr/classification/litteratures/litteraturegeneralites/techniques-litteraires/rhetorique/figures-de-style/ (Letöltés ideje: 2019. 07. 08.) figre de style (stíluseszköz)

${ }^{167}$ Deleuze, Gilles (2014). Francis Bacon. Az érzet logikája, Budapest, Atlantisz Könyvkiadó (fordította: Seregi Tamás) Elérhető: https://docplayer.hu/2636936-Gilles-deleuze-francis-bacon-az-erzet-logikaja.html Letöltés ideje: 2019. 07. 20.

${ }^{168}$ Uo. 3. J. F. Lyotard használja a „figurális” szót főnévként és a „figuratív” ellentéteként, vö. Discours, Figure. Klincksieck, Párizs, 1971.
} 
eszközök hatásmechanizmusaival építi ki a kapcsolatot a befogadó és az alak között. Nem identitások találkoznak, nincs sürüsége ennek az egymásra hatásnak, de a szöveg törésvonalai mentén létrejön a találkozás annak következtében, hogy bár kilép a fikciós mesélö módból is, továbbá több ízben a pragmatikus szinten értelmezhető beszéd- és élethelyzetből is, az alak segítségével kettőközötti világot hoz létre. Ugyanakkor ez a világ, ha van beszédhelyzet, akkor az eltérő beszédhelyzetek felvonultatása segítségével azért konstans, mert Sarraute beszédmódja, nyelvhasználata, szintaxisa nem csak az adott müvön belül, hanem már-már az életmű teljességén belül kiszámíthatóan ugyanaz. Stabil, identitással rendelkező szereplő hiányában az alak feladata, hogy biztosítsa az eltávolító ${ }^{169}$ gesztust mintegy átszürve magán a jelenlétek, hangok, tekintetek, érzetek sokaságát, amelyek a szöveg és az olvasó között áramlanak.

Nem hiszek a szereplő válságában. Bizonyos szövegekben továbbra is helye, szerepe van a megjelenő karaktereknek. A Sarraute-univerzum alak-értelmezése tautologikusságában megragadható, hiszen arra hív, hogy ne lássunk mást és ne akarjunk több, más érzetet befogadni, mint amit a szöveg befogadásának adott pillanata, az alakkal való találkozás adni tud. A befogadó és az alak kapcsolata tehát nem azon a hiten alapul, hogy a szöveg valóságmodellt hoz létre, hanem azon, hogy egy más természetü, csak a megalkotásnak és a befogadásnak a szövegben létrejövő metszéspontjában jöhet létre valódi találkozás.

A figura fogalma etimológiailag is összefügg a fikció fogalmával. Az arc a keresztény szimbolika elterjedése óta a legmélyebb igazság, belső lelki értékek és állapot kisugárzásának helye, tere ${ }^{170}$. Számos szólás, közmondás tanúskodik erröl. Deleuze és Guattari fogalma az arcadás ${ }^{171}$, amelynek lényege, hogy a társadalmi intézményesülés keretében a személyiség az arcban ölt alakot. ${ }^{172}$ Szerintük az arcadás arra szolgál, hogy a szubjektum látható formáinak, jelenségeinek, intenzitásainak sokszínűségéhez normatív, egységes értelmezést, jelentést adjon. Ilyen értelemben halálos: rögzíti és elzárja a látható többjelentésűségét, ahogyan hozzárendeli egy transzcendens fogalomhoz (értelem, alany), globális magyarázó elvnek veti alá, amelynek az arc csak redundáns tükörfelülete. Az arcadás ilyen értelemben a sarraute-i reprezentációs, valószerü narratívához kapcsolódna. A figura ettől eltérően a reprezentáció figurális síkja, az arctalanítás gesztusát hordozza, kereső fejek poétikáját. A perszona maszk, megfosztja a szereplőt az identitásától. Az arc realista, ilyen értelemben Nathalie Sarraute szereplői modellje az arctalanítás, az arctól való eltávolítás folyamatához kapcsolható.

\footnotetext{
169 distanciation

${ }^{170}$ Deleuze-Parnet (2016). p. 41. „Krisztus találta fel az arcot.”

${ }^{171}$ Uo. visagéification p. 20.

${ }^{172}$ Uo. fekete lyukak a fehér falon - U.o.
} 
Paul Ricœur ${ }^{173}$ szerint az identitás alapja az ismétlés (identité-idem). Az alany mássáleendésekben van, variációkban, változatokban, átalakulásokban (identité-ipse) archeologikus szubjektivitás, kartografikus szubjektivitás. Eltávolodik mindattól, ami látható (figura): ami figuratív, tér-, idővonatkozásokban, pragmatikusan megragadható, ami szimbolikus (típus): kulturális, lelki vagy történelmi értelemben egy közösség látható jele, tükröződése, és attól, ami írástechnikailag (szereplö) a klasszikus narrativitáshoz köti: cselekmény, hely, idő, szereplök.

Nincs történetmesélés, de művészi célzatú hatáskeltés, esztétizáló beszédmód van: a jelentésegységek tudatos megszerkesztettsége, sürítés, a diskurzus performativitása változtasd meg élted, és valamiféle mozdulatokból és képekből összeálló beszédhelyzet, amelyet a dadogó beszédmód közvetít Sarraute-nál.

Az 1980-as, 90-es évek fordulóján a fikció problematikája számos irodalomelméletírót foglalkoztatott ${ }^{174}$. A lehetséges világok elmélete, fogalmának bevezetése tette lehetővé, hogy a könyv belső világát mint a valóságtól független valóságot le tudjuk írni és el tudjuk gondolni. A regény szavakra felfüzött verbális reprezentáció, életállapotok, beszédhelyzetek, helyszínek hipotetikusan felfüzött sora, a szereplők pedig ennek a lehetséges világnak a részei. El lehet őket látni identitással, tulajdonságokkal, karakterrel, kapcsolatokkal, belső világgal, személyiséggel. Derrida a mimézis idealista koncepciójának dekonstrukcióját hajtja végre a nyelv jelenlétének mítoszát lebontva. Maurice Blanchot Hölderlin, Mallarné és Kafka írásaiban keresi, még Derrida előtt, az intranzivitás morzsáit és a nyelvi kifejezés adekvátságának utópiájáról beszél.

\section{Nathalie Sarraute stílusfogalma. A szereplő stilisztikája}

A szereplőfelfogás változásaiból is látszik, hogy a szereplő megjelenési módjai a kortárs epikus irodalomban olyannyira szerteágazóak, hogy elsősorban nyelvi kivetüléseik ${ }^{175}$ eltérésében értelmezhetőek különbözőségeik, ilyen értelemben a szereplőfelfogás stilisztikai változatainak vizsgálata válik elsődlegessé. Ahhoz, hogy erre rátérjünk, elengedhetetlen a stílus és a stilisztika fogalmának valamiféle modern megragadása, megközelítése. Egyre inkább előtérbe kerülnek a kérdések, hogyan hozza létre az író a művét, hogyan épül fel a mü, hogyan alkotja meg a szereplőt - többé nem azt veti fel, hogy miről szól a mü vagy mit üzen a

\footnotetext{
173 Bókay Antal (1997). Irodalomtudomány a modern és a posztmodern korban, Budapest, Osiris, p. 283-289.

${ }^{174}$ Uo. p. 353-417.

175 Gérard Dessons. (2000) Introduction á l'analyse des poèmes, Paris, Nathan
} 
főhős jelleme, esetleg személye ${ }^{176}$. A szereplő stilisztikája szorosan kapcsolódik David Fontaine „választás” ${ }^{177}$ fogalmához: „tudatos vagy nem tudatos választás az író részéről, amely a szöveg megszerkesztettségére, a műfajra, a stílusra vagy a témára vonatkozik"178. A stilisztikai megközelítéshez kapcsolható Valéry poétika-fogalma is ${ }^{179}$. Értelmezésében benne rejlik még a középkori és reneszánsz retorikai iskolák normativitásának utóíze, ugyanakkor a

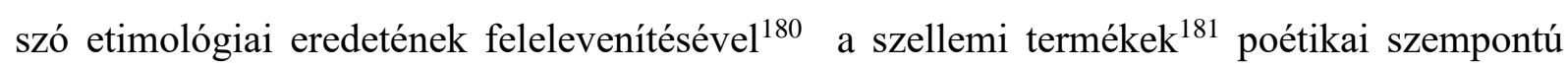
megközelítését elkülöníti az írás körülményeit taglaló irodalomtörténettől, illetve az értékítéletre törekvő irodalomkritikától. A poétika tárgyának az alkotást mint a létrehozás folyamatát tekinti: „(...) a szellemi alkotás magában a létrehozás aktusában létezik. Ezen az alkotói gesztuson kívül nincs semmi. Ami marad, az egy vizsgált tárgy, ami a szellemmel nincs semmilyen kapcsolatban"182.

Sarraute stílusinvenciója, a szómögöttes beszédfolyam közvetlenül a mentális struktúráinkból feltörő, kiáramló, ilyen értelemben a kognitív folyamatainkat formátlanul tükröző mélyrétegű valóság. Megmunkálatlan állapotban kerül elénk a szövegekben, úgy, hogy még nem individuálódott, nem is individuálódhatott, ezért nincsenek Sarraute-nál szereplők, hanem csak tropizmus-foglalatok, amelyek mintegy stílusjelenségként hordozzák a pozitív vagy negatív tropizmusokat. Ahogy Tison-Braun fogalmaz: „itt nem a hagyományos, szoros értelemben vett stílusfogalomról van szó, hanem kifejezésmódról, azaz egy nyelvileg megformált eljárásról, amely számot ad, felfoghatóvá tesz egy olyan tapasztalati valóságot,

\footnotetext{
176 Jarrety, Michel (2003.) La Poétique, série Que sais-je?, PUF Elérhető: https://www.cairn.info/la-poetique-9782130533030-page-3.htm (Letöltés dátuma: 2019. 07. 05.) Jarrety a fabrication (gyártás, legyártás, készítés) szót használja. Hogyan „készül” az irodalmi alkotás.

177 Valójában itt az écart fogalmának előképéről van szó, amely sokáig kitartott mint a modern stilisztika egyik alapfogalma. Adam - variáns fogalma in Todorov (1972). p. 383.

Schaeffer (1997). Littérature $\mathrm{N}^{\mathrm{o}}$ 105. p. 20. "Nous définirons plutôt le style comme le choix que tout texte doit opérer parmi un certain nombre de disponibilités contenues dans la langue." / „Stílusértelmezésünk alapja a választás fogalma - a nyelv eszközkészletéből rendelkezésre álló variánsok közötti választás folyamata a stílusképzés." Ilyen értelemben minden nyelvhasználat választások eredménye és nincs stílussal jelzett vagy semleges megnyilatkozás. Csak mindig különféle sajátos jegyekkel ellátott megnyilagkozások vannak."

${ }^{178}$ Fontaine, David. (1993), La poétique, Paris, Nathan, p. 8-9. lásd még Tzvetan Todorov (1972). "Poétique" szócikk in Dictionnaire encyclopédique des sciences du langage (1972), Le Seuil, „(...) choix conscient ou non, que fait un écrivain (et pas seulement un poète) dans l'ordre de la composition, des genres, du style ou des thèmes".

179 Valéry, Paul (1937). Première leçon du cours de poétique, Elérhető: http://classiques.uqac.ca/classiques/Valery_paul/varietes/Lecon_1_esthetique_Var_V/lecon_1_esthetique.html Letöltés: 2019. 07. 06.

180 ,poiein” görög szó „csinálni”

181 les œuvres de l'esprit

182 U.o. „,...) l'œuvre de l'esprit n'existe qu'en acte. Hors de cet acte, ce qui demeure n'est qu'un objet qui n'offre avec l'esprit aucune relation particulière."
} 
amely eredendően belső és zavaros" ${ }^{183}$. A néven nem nevezhető mélyrétegek és a konvenciók rendszereként felépülő, a világot leegyszerüsítő, a közlés kényelmét szolgáló nyelvhasználat kibékítése, egységesítése történik meg az irodalmi szövegben, a stílusban ${ }^{184}$.

\section{IV.1. A stílusfogalom modern és posztmodern kori jelentősége}

A stílusfogalom valamilyen formájában mindig is az irodalomról való beszéd része volt, hiszen az irodalom a nyelvet használja fel „nyersanyagként”, és a nyelvi formák, a nyelvhasználat valamennyi szintje (hangok, szavak, szószerkezetek, mondatok, szöveg) egy testként lélegzik, amikor irodalmi alkotás születik. Ma a modern stilisztikai irodalmak gyakran elméleti bevezetést nélkülöző gyakorlati szakmunkák, s legtöbbször interdiszciplináris jellegűek. ${ }^{185}$ A strukturalista elméleti érában a Langue Française 1969-es 3. számában a nyelvészek bejelentik a stilisztika halálát, pontosabban az irodalmi stilisztikáét. „Ennek a lapszámnak a szerkesztői és szerzői majdnem mind meg vannak győződve arról, hogy a stilisztika meghalt."186 Nem véletlen, az első nyelvészeti stiliszta Saussure követője, Charles Bally ${ }^{187}$. Az irodalmi stilisztika átadja a helyét a nyelvészeti stilisztikának ${ }^{188}$. „A stilisztika modernizálása természetes egységesítése azoknak a különféle nyelvészeti megközelítéseknek, amelyek irodalmi szövegekkel foglalkoznak: szövegnyelvészet, pragmatika, szemantika, szemiotika, retorika és poétika."189 A stílusfogalom elszakad a retorika elöírásos, normatív, preskriptív attitüdjétől, ám fenntartja terminológiáját. ${ }^{190}$ „A retorika elsősorban szövegek létrehozásának szabályrendszerét alkotja meg, a stilisztika pedig az értelmezésben segít."191 A stilisztika mint az irodalmi szövegek szövegközpontú megközelítése tehát továbbra is az érdeklődés homlokterében van, de modern és precíz terminológia és vizsgálati módszerek kidolgozását igényli. „Megkísérlünk rendet tenni abban

\footnotetext{
183 Tison-Braun (1971). p. 17. „Notons seulement qu'il ne s'agit pas ici de style au sens étroit du mot, mais bien de mode d'expression, c'est-à-dire de la manière de rendre compte d'une expérience, de rendre intelligible, communicable, ce qui est à l'origine subjectif et confus."

${ }^{184}$ Sarraute, Nathalie, Ce que je cherche à faire

${ }^{185}$ Herschberg Pierrot (1993). Maingueneau (1993).

186 Adam (1997), p. 16. idézi Arrivé-t "Les collaborateurs mêmes de ce numéro semblent à peu près tous persuadés de la mort de la stylistique"

${ }^{187}$ Bally, Charles (1905): Précis de Stylistique

${ }^{188}$ Barcy (1992). ; Fromilhague (1992).

${ }^{189}$ Adam (1997), p. 23. "l'opération de modernisation de la stylistique passe, presque naturellement, par la fusion œcuménique de travaux de linguistique énonciative, pragmatique et textuelle, de sémantique et de sémiotique, de rhétorique et de poétique."

${ }^{190}$ Az 1970-es években kidolgozott általános retorika egy liège-i tudós csoport, a Groupe $\mu$ nevéhez füződik. Kézikönyvük újratárgyalja a klasszikus retorika szókészletét, adaptálja a modern irodalomértelmezés eszköztárára. Groupe $\mu$ (1982), p. 8.

${ }^{191}$ Jenny (2000), p. 103. "la rhétorique est originairement une technique productive de discours, et la stylistique une technique de lecture et d'interprétation"
} 
az esztelen rendetlenségben, amely az irodalmi stilisztikát jellemzi és fogalmi rendteremtést végzünk ebben az oly gyakran és széles körben használt fogalomkörben.”192

Továbbra és folyamatosan a nyelvi megformálás van az irodalmi vizsgálódások középpontjában. „Megmagyarázni, hogyan és miért válik a szöveg szöveggé (...) melyek azok a nyelvi folyamatok, amelyek létrehozzák az irodalmiságot." ${ }^{193}$ Az értelmezés tárgya az anyag, a forma, a művészi megformálás. „A stilisztika az irodalom formális megoldásainak technikai vizsgálata." ${ }^{194}$ A stilisztika háttértudománya a modern humán tudományosságban a szemiotika - terminológiát képez és folyamatos önkritikát folytat ${ }^{195}$, a nyelvészet és a többi humán tudomány között áll úgy, mint „nyelv” és „beszédei” között ${ }^{196}$. A stilisztika megragadja a nyelvi jelet ${ }^{197}$, amely nem más, mint az irodalmi szöveg görbéjének egy adott pontja a szintagmatikus tengelyen a szemiotika pedig ugyanezt teszi, csak a paradigmatikus tengelyen. A stilisztika azt vizsgálja, hogyan válik az irodalmi szövegben egy nyelvi jelenség jellé, mi teszi azzá, a szemiotika pedig azt, hogy mi ez a jel, melyik jelrendszeren belül érvényes, milyen értékeket hordoz. A stilisztika praxis, a szemiotika elmélet. A szemiotikai kutatás szókincse szükséges ahhoz, hogy beszélni lehessen a stilisztikai jelenségekről úgy, mint « [jelentéssel telített] nyelvi elemek keresése az irodalmi szövegben ${ }^{198}$

Fentieken túl, tehát azon felül, hogy a modern-posztmodern irodalmi szöveghagyományban a tartalomról a formára, az üzenetről a nyelvi megformálásra kerül a hangsúly, az irodalomértelmezés egyre inkább parole-jelenségként értelmezi a vizsgált szövegeket. Ilyen értelemben a megfigyelés fókuszában a beszédhelyzet és a szöveg mint beszéd áll. A stílus pedig a beszédhelyzet része, beszédjelenség parole ${ }^{199}$ éppen úgy, mint nyelvi jelenség ${ }^{200}$, vagy pontosabban a kettő közötti átmenetet képezi, mint a két agyfélteke közötti kéregtest. Ezek szerint a stiliszták szerint csak a szöveg szintjén találkozhat a stílus és nyelvtani felépítés: a szöveg kontextusába helyezett nyelvi jelenségekből hámozhatók ki a

192 Groupe $\mu$ (1982.), p. 11. "un désordre insensé à propos (...) de la stylistique littéraire » et ils tentent « une mise en ordre théorique de ce vaste domaine si largement fréquenté"

${ }^{193}$ Uo. p. 14. "même d'expliquer comment et pourquoi un texte est un texte, (...) quels sont les procédés de langage qui caractérisent la littérature."

${ }^{194}$ Moliné (E.U.) p. 705. "La stylistique est l'étude technique des conditions formelles de la littérarité"

195 Barthes, (1985), p. 14. "Il appartient à la sémiologie, et peut-être, de toutes les sciences humaines, aujourd'hui, à la Sémiologie seule, de mettre en cause son propre discours : science du langage, des langues, elle ne peut accepter son propre langage comme un donné, une transparence, un outil, bref un métalangage..."

196 Uo. p. 35.

197 Jakobson, Roman (1982). A költészet grammatikája, ford. Albert Sándor, Budapest, Gondolat

${ }^{198}$ Moliné (E.U.) p. 707. Továbbá Fontanille (1999). Sémiotique et littérature (1999), Maingueneau (1993). Les éléments de linguistique pour le texte littéraire (1993)

${ }^{199}$ Un phénomène qui se procure d'une valeur significative dans une situation concrète de communication.

${ }^{200}$ Moliné in E. U. p. 707. Un réseau de déterminations formelles qui se structures d'une façon fonctionnelle à l'intérieur d'un discours. 
stílusjelenségek. Az író a stílushatást a nyelv segítségével a szövegben hozza létre ${ }^{201}$. Az értelmezés nem lehet a szövegben elrejtett, kódolt jelentések kutatása, de a szöveg nem is „hétköznapi kommunikáció, (amely a doxa, a vélemény) alá van vetve, hanem a jelölővel való kombinatorikus játék” ${ }^{202}$. „Az irodalmi szövegeket mintha idegen nyelven írták volna”203. Már Charles Bally ${ }^{204}$, Saussure kortársa is a langue-tól, a nyelvtől a parole-ig, a beszédig való elrugaszkodásnak tételezte a stílust, ilyen értelemben kollektívből egyéni, szociolektálisból idiolektális nyelvhasználat, tehát mindenképpen a szubjektivitás nyelvileg megformált eszköze. „formális valóság, független a nyelvtől és a stílustól (...) amelyek a társadalmi függőséget kialakítják az íróban”. Ahogy Barthes fogalmaz: „A nyelv az Irodalmon innen van. A stílus majdnem azon túl" 205

\section{IV.2. Nathalie Sarraute stílusfogalma}

Roman et réalité [Regény és valóság] címü esszéjében ${ }^{206}$ Nathalie Sarraute úgy jut el a stílusfogalom szükségességéhez, hogy az ismert ${ }^{207}$ valóságot elkülöníti az ismeretlen valóságtól, és íróként az ismeretlen valóság kibontását célozza. „Ezért rákényszerültem, hogy olyan formai megoldásokat alkalmazzak, amelyek keresgélésemből következnek."208 Az ismert valóság ábrázolását biztosító nyelvi eszközöktől kívánja eltávolítani az olvasót, ugyanakkor arra hívja, hogy „elmerüljön a láthatatlan drámák mélyrétegeiben anélkül, hogy tudná, hol van valójában."209 A megírás szintjeit tropizmikus és a látszatokat felmutató realista írásmódra különíti el. Az utóbbi esetben az üzeneten van a hangsúly, míg a tropizmus megalkotottsága kizárólag stilisztikai eszközökkel lehetséges. A stílusfogalomhoz tehát az új, ismeretlen valóság feltárásának egyetlen lehetősége: az újfajta nyelvhasználat igénye vezeti el az írót.

\footnotetext{
${ }^{201}$ Adam (1997) p. 29-31. idézi Gérald Antoine-t

${ }^{202}$ Barthes Texte (Théorie de) in E.U. p. 372. "la communication courante (soumise à l'opinion, à la doxa) et de la vraisemblance narrative ou discursive"

${ }^{203}$ Adam (1997), p. 34. idézi Proust: Contre Sainte-Beuve

${ }^{204}$ Uo. p. 46-53. idézi Bally, Charles: Traité de stylistique française $(1909,1951)$ et Le Langage et la vie $(1913$, 1965)

${ }^{205}$ Uo. p. 14. idézi Barthes, Le degré zéro de l'écriture (1964). "La langue est donc en deçà de la Littérature. Le style est presque au delà..."

${ }^{206}$ Sarraute, Nathalie (1996). "Roman et réalité" in Euvres complètes, p. 1652.

207 connu / inconnu

${ }^{208}$ Sarraute, Nathalie (1996). "Roman et réalité" in Euvres complètes, p. 1652. „J'ai été obligée d'adopter des formes qui m'étaient absolument imposées par ma recherche."

${ }^{209}$ U.o. p. 1654. „En empêchant le lecteur de se tenir á distance, en l'obligeant á plonger au cœur des frames invisibles, avant de savoir où il est."
} 
„Valamennyi könyvem témája a születőben lévő, megnevezhetetlen, a tudati szintre még el nem jutott, de a tudati szint fölé jutva frázissá váló mozgás, mely folyamatos átalakulásban, állandó leendésben van." ${ }^{210}$ A már említett mozgás, mozdulat ${ }^{211}$ fogalma mellett az ábrázolandó ismeretlen valóságot még ,érzetnek”212 is nevezi Sarraute. Ennek a folyamatos, és a felszínre csak időnként és csak sztereotipikus megnyilvánulásokban feltörő mozgássornak vagy ezeknek az érzeteknek nem a feltárása zajlik, hanem a klasszikus formáktól való eltávolítás segítségével csupán stílusmozzanatokkal érzékelteti szakadatlan hullámzásukat. A klasszikus narrativitásból való kibontakozás igénye egyértelmü: ahogyan a modern zene eltávolodik az érzelmeket hordozó dallamtól, az absztrakt festészet a felismerhető alakoktól, a költészet a retorikai felépítéstől és a rímtől, úgy

\begin{abstract}
„,örekszik a regény arra, hogy kiszabaduljon a szereplö és a cselekményvezetés szorításából és a tiszta érzethez kapcsolódjon, amelyhez csak bizonyos szemlélet által juthatunk - a tárgyaknak, a külső világnak vagy az emlékezet játékainak vagy az idő múlásának vagy egy-egy óriásira felnagyított jelen pillanat gazdagságának vagy a megcsontosodott formákon is átsejlö, alig tudatos belső mozgássoroknak a sajátos szemlélete által.”213
\end{abstract}

Klasszikus narrativitás helyett maga a stílus az írás gerince.

Az Új Regény képviselőivel szembeni vádakra is válaszol az írónő. ${ }^{214} \mathrm{~A}$ konvencionális formáktól való eltávolodás „megölte” a regényt: „laboratóriumi” körülményeket teremtettek, tudatosan elzárkózva a társadalmi valóságtól és az olvasótól, akiben csupán az unalom érzését képesek felkelteni. Ezekre a vádakra válaszul az Új Regény egyes képviselői méginkább radikális álláspontot foglaltak el a tiszta, valóságra vonatkozó referencialitást teljességgel nélkülöző formák esztétikai értékének hangsúlyozásával. „Az egyetlen valóság a művészetben a művészet”. „A műalkotás modellje maga a műalkotás, csak önmagára vonatkoztatható”. „A forma és a tartalom egyek.” ${ }^{215}$ Sarraute egyetért a mimetikus, klasszikus narratív technikákkal való ábrázolás mellőzésével, azonban amit ő szövegszerüen érzékeltetni szeretne, az a valóság ismeretlen arcának eredeti látásmódja, az általa keltett

\footnotetext{
${ }^{210}$ Sarraute, Nathalie (1996). "La littérature, aujourd'hui" in CEuvres complètes p. 1662. „Des mouvements á l'état naissant, qui ne peuvent pas encore être nommés, qui n'ont pas encore accédé á la conscience où ils se figeront en lieux communs, forment la substance de tous mes livres. Ils sont en constante transformation, en perpétuel devenir."

211 mouvement

212 sensation

${ }^{213}$ Sarraute, Nathalie (1996). "Forme et contenu du roman" in Euvres complètes p. 1673. „De même le roman tend á se débarrasser de l'emprise du personnage et de l'intrigue pour s'attacher á la pure sensation que procure une certaine vision des objets, du monde extérieur, ou des jeux de la mémoire, ou de l'écoulement du temps, ou des richesses d'un instant présent démesurément agrandi, ou de mouvements intérieurs á peine conscients et de leur percée á travers des formes sclérosées." in Forme et contenu du roman in Euvres complètes (1996) p. 1673. ${ }^{214}$ Uo. 1674.

${ }^{215}$ Uo. p. 1675. „Le seul réel dans l'art, c'est l'art.” idézi Valéry-t ; „L'œuvre d'art est son propre modèle, elle ne renvoie qu'á elle-même.” „La forme est son propre contenu.”
} 
érzetek. Tehát stílusfogalmában nem mond le a nyelvi és a nem nyelvi realitás kapcsolatáról. De azt mondja, hogy tartalmilag nem, csupán formailag, stíluselemekkel lehet érzékeltetni, s nem is azt, ami van, hanem annak szemléletmódját, az abból kilélegzett érzeteket. „Csak a forma által ragadhatóak meg a realitásból felszabaduló érzetek, amelyeket a látásmód életre fordít. A forma adja vissza, a forma megszünésével enyészik el, egyenlő lesz a formával."216 Anélkül a stílusforma sem jöhet létre, hogy az író nem létesített valamiféle kapcsolatot a világgal, nem kezdett vágyni arra, hogy a titokzatos módon pont az ő rendelkezésére álló személeti forma közvetítőjévé lépjen elő. Ha ez a vágy már feléledt és a stílusforma megszületett, az akár önálló életre is kelhet, nincs további ráhatása az írónak.

Látható tehát, hogy Sarraute stílusfogalmából hiányzik a kommunikáció mint közvetítés gondolata. Ahogyan Tison-Braun megyjegyzi: „Nathalie Sarraute nem elemez, nem magyaráz semmit, nem lép közbe. Egy kép körül kristályosodik ki a érzékeltetésre váró érzet: a megfeszülő majd elernyedő, lelógó karé."217 A képalkotás szerepe Sarraute-nál az, hogy hatékonyabbá, hitelesebbé, igazabbá tegye születő mentális valóságunk, érzethullámzásaink esetleges közvetíthetőségét, ám „,a kép itt nem metafora - vagy allegória , amely a megértést segítené; nem átírás, fordítás, (...) hanem a születőben lévő gondolat, 'mentális lenyomat' intellektuális megalkotottsága - és deformálása - előtti állapotában."218 Nincs tehát közlés, nincs konceptek közvetítése, a kép felülírja a fogalmat, és a fő szókép tehát a tropizmusokban nem a fogalmi érthetőséget képszerüséggel alátámasztó metafora, hanem a metonímia, az egymás mellé helyezés, a helyettesítéses utalás, az újrakezdés. Az alapalakzat pedig az ismétlés, a felsorolás, a mellérendelés, a deleuze-i dadogás.

A nyelvi megformálás „összeköttetés” ${ }^{219}$, szerepe valami önmagán kívülálló ${ }^{220}$ átadása - láthatatlanná válva erre irányítja a figyelmet. A stílus olyan, mint egy ,jólfésült háziszolga". ${ }^{221}$ Életünk minden területén a nyelvet használjuk, gazdagsága, konnotációi

\footnotetext{
${ }^{216}$ Uo. „Ce n'est que par cette forme que la sensation dégagée par la réalité, que la vision prendra vie. Elle sera rendue par la forme, elle se fondra avec la forme, elle sera cette forme."

217 Tison-Braun (1971). p. 21. „N.S. n'analyse rien, n'explique rien, n'intervient pas. C'est autour d'une image que la sensation se cristallise : celle du long bras prenant qui se tend et retombe."

${ }^{218}$ Uo. p. 22. „L'image ici n'est pas une métaphore - ou une allégorie - destinée à faciliter la compréhension ; ce n'est pas un transcription, une traduction (...)" "C'est la pensée même en train d'éclore, la 'matière mentale' avant son élaboration - et sa déformation - par l'intelligence."

${ }^{219}$ véhicule

${ }^{220}$ Sarraute (1996). "Le Langage dans l'art du roman" in Oeuvres complètes p. 1681.,,sa fonction consista á transmettre... á transmettre le mieux possible quelque chose qui se trouve en dehors d'elle".

${ }^{221}$ Uo. p. ,un domestique bien stylé”.
} 
kimeríthetetlenek. ${ }^{222}$ Ugyanakkor a „regény” és a „regény mint műalkotás”223 nyelvezete elkülönül, és ezt az eltérést ${ }^{224}$ már sokan, sokféleképpen igyekeztek stílusfogalomként megragadni. Mallarmé például a nyers beszéd és a sürített beszéd ${ }^{225}$ fogalmainak elhatárolásával. Nem jöhet létre művészi regény, ha a közlés célja csupán az információáramlás, mert a stílus segítségével az érzetek forrásához kell vezetnie az írónak az olvasót. ${ }^{226}$ Sarraute a fluiditás, hajlékonyság, erőteljes kifejezések, szuggesztív erő, egyediség, frissesség fogalmakkal ${ }^{227}$ írja körül stílusfogalmát, illetve pontos kereteket is ad a nyelvi megformáláshoz: képszerűség, ritmikusság, nyelvteremtő erő, tudatos mondatszerkesztés ${ }^{228}$.

Amikor az írónő a kapcsolatot keresi az érzetek és a nyelvi-stilisztikai megformálás között, akkor le kell szögeznie, hogy az érzetek nem nyelvi természetűek, míg a regényforma nyelvi természetü.

„Amikor New York vagy Párizs utcáin sétálok, olyan érzetek lepnek meg, amelyeket egyetlen szó, még a kimondatlanok sem tudnak visszaadni, szinte fizikai jellegüek, kívül esnek a szavak világán. Abból fakadnak ugyan, amit fizikailag érzékelek... Mégsem úgy öntöm szavakba, hogy leírom, amit érzékelek." ${ }^{29}$

Ebben stílusa egyébként nagyban eltér az Új Regény képviselőitől, hogy egyáltalán nem leíró jellegüek epikus művei. A stílusnak tehát magát az érzetet kell titokzatosan éltetni a nyelvhasználat benne egyesül az érzettel, az alkotás pedig sajátos életet nyer, amely önállóságában, függetlenségében elkülönül a megélt valóságtól, hogy további érzetek forrása legyen. Ezt nevezi Sarraute esztétikai élménynek. ${ }^{230}$ A nyelv és a szavak nélküli régiók közötti átjárhatóság megteremtése a nyelv feladata - „mozdulathullámok, lehetőségek, homályos és átfogó érzetek, meg nem nevezhető, szavaknak ellenálló régiók; és mégis

\footnotetext{
222 Esterházy Péter: A szavak csodálatos életéből. https://mindentudas.hu/el\%C5\%91ad\%C3\%A1sok/tudom\%C3\%A1nyter\%C3\%BCletek/b\%C3\%B6lcs\%C3\%A9 szettudom\%C3\%A1ny/139-irodalomtudom\%C3\%A1nyok/6017-a-szavak-csodalatos-eletebol.html Letöltés ideje: 2019. 08. 15.

${ }^{223}$ Sarraute (1996). "Le Langage dans l'art du roman" in Oeuvres complètes p. 1683. roman-oeuvre és art du roman tout court

${ }^{224}$ Uo. écart

${ }^{225}$ Uo. p. 1685. parole brute, parole essentielle,

226 Uo. p. 1685.

${ }^{227}$ Uo. p. 1686. fluidité, souplesse, force d'expression, pouvoir de suggestion, singularité, fraicheur

${ }^{228}$ Uo. images, rythmes, assonances, retrouve ou découvre des mots, coupe ou allonge les phrases

${ }^{229}$ Uo. p. 1690. „Quand je me promène dans les rues de New York ou de Paris, j'éprouve des sensations qu'aucun mot, même intérieur, ne traduit. Elles sont presque d'ordre physique. Elles existent hors des mots. Elles se dégagent de ce que je regarde..."

${ }^{230}$ Uo. p. 1691. jouissance d'ordre esthétique
} 
vonzzák a szavakat, hiszen nélkülük létezni sem tudnak." ${ }^{231}$ Ezt az önellentmondást oldja fel az irodalmi szöveg, bár minden pillanatban fenyegetettségben ${ }^{232}$ van, mert eltávolodhat életet adó forrásától.

$\mathrm{Az}$ erőfeszítés ${ }^{233}$ az az újra meg újra visszatérő kifejezés, amellyel Sarraute stílusfogalmában az írónak ${ }^{234}$ a szavak nélküli régiók verbalizálására vonatkozó törekvését jelöli. A nyelv hatalmi gépezetével, a jelentések megszokott rendjével nem törődve kell az érzetek tiszta forrásához járulnia, a megszokott denotációk, a lélektani kategóriák, a szótári definíciók helyett a formátlant, remegöt, a bizonytalant választania. Sarraute legtöbbször erőfeszítésnek, de néhol harcnak ${ }^{235}$ nevezi az írónak ezt az igyekezetét.

\section{IV.3. Nathalie Sarraute és Gilles Deleuze stílusfogalmának egymásra vetítése - a dadogás mint központi fogalom és stílusforma}

Ahogyan a tropizmus sem mimetikus, úgy Deleuze fogalomrendszerében a „leendés soha nem utánzás, másolás, nem igazodás egy igazság- vagy valóságmodellhez." ${ }^{236} \mathrm{~S}$ mivel a leendés áramlás, folyamat, nem lehet jelölők és jelöltek csapdájába csalni - „a leendések a legészrevétlenebbek: olyan cselekvések, amelyeket csak egy élet tud magába foglalni, csak egy stílus tud kifejezni." ${ }^{237}$ Dadogni számára annyit jelent, mint írni, beszélni, kifejezni magunkat, akár lehet a dadogás maga az irodalom metaforája is. Nem az eltérésre utal itt, ami a hétköznapi nyelvet kibillenti az egyensúlyából, annak minden szintjén, a hangok, a szavakszószerkezetek, mondatok vagy akár a szöveg szintjén. Arról van szó, hogy a nyelvhasználat mint olyan, s föleg az, amely irodalmi szövegek alapját képezi, ,az összeomlás szélére sodortatik” "238. Ez a beszédmód, ,a nyelvhasználat külterülete”, de nem „esik kívül a nyelven”239, azaz az irodalmi nyelvhasználat a határáig feszíti a nyelvi szabályrendszert, sőt, még talán azon is túl, akár egészen a zeneiségig, oda, ahol formálódnak a szavak és „(még) csak a csend hallható általuk"240. A csend tapintható felülete az írás segítségével létrejövő

\footnotetext{
${ }^{231}$ Sarraute (1996). "Ce que je cherche á faire" in CEuvres complètes p. 1700 „mouvance, virtualités, sensations vagues et globales, vers ce non-nommé qui oppose aux mots une résistance et qui pourtant les appelle, car il ne peut exister sans eux."

232 menacé

233 effort

234 écrivant

235 Uo. p. 1704. lutte

236 Deleuze, Parnet (2016). p. 8.

237 Uo.

${ }^{238}$ Deleuze, Gilles (1993) p. 137.

${ }^{239}$ Uo. p. 141.

${ }^{240}$ Uo. p. 142.
} 
zeneiség, a dadogás. Deleuze kivételesen egészen egyszerűen fogalmaz. „A stílusban nem a szavak, a mondatok, a ritmus vagy az alakzatok számítanak. Ahogy az életben sem a történetek, az alapelvek vagy a következmények. Egy szót bármikor helyettesíthetünk egy másikkal. Ha az sem tetszik, ha az sem megfelelö, tegyünk újat a helyébe." ${ }^{241}$ Röviden a dadogás a nyelv határhelyzetbe sodrása, a nonverbalitásból való kibontakozás pillanatára való rátalálás, és ezzel összefüggésben szavak keresése, annak beismerése, hogy nincs végső formája a gondolatnak, hanem újra és újra alakot ölt a nyelvben, majd módosul.

Sarraute stílusfogalma annyiban hasonló Deleuze-éhez, hogy a megszólalás forrását a szómögöttesben keresi, a nonverbálist azonban nem csendként, hanem inkább mozdulatként ${ }^{242}$, testiségként (érzetként) ${ }^{243}$ képzeli el. Deleuze nyelvhasználata konceptuális szinten dadog, újra és újra fogalmakat keres, majd átformálja, más konceptek szomszédságában átértelmezi őket. Az irodalmi alkotás tekintetében van az, hogy a nyelv dadog. Amikor irodalmi példát keres, akkor például Luca Je t'aime passionément [Szenvedélyesen szeretlek] címü költeményét hozza fel a dadogást megvalósító irodalmi mü példájaként. ${ }^{244}$ A Luca-életműhöz hasonló nálunk Tandori Dezső költészete, akitől számos hasonló, a deleuze-i értelemben dadogó írást ismerünk. Például: A Sátán körbemutogatja Jézusnak a világot. ${ }^{245}$ Ezekben a nyelvi alakzatokban nyelvi játékot, egymástól jelentésükben független szóláncokat találunk, amelyeket valami egészen más füz össze, mint sorba rendezettségük jelentésessége. Jellé válnak, a szemiózis részei, tehát kulturális ismereteink segítenek minket a szóhalmaz értelmezésében, és nem szemantikai érzékünk. Sarraute irodalmi beszédmódja egészen másféleképpen dadogó, sokkal inkább a nonverbalitás fizikai valóját igyekszik képszerüen újra- és újrapróbálva formába önteni. Deleuze a dadogás alapvető nyelvi kivetülésének tekinti az ,és” kötőszó használatát ${ }^{246}$, amire indoka, hogy az és stilisztikája fejezi ki leginkább azt a kettő-közöttiséget, amitől irodalom az irodalom, leendés, két-magány-közöttiség. A Sarraute-szöveg erre rezonál, hiszen mellérendelések sorát hozza létre.

Nathalie Sarraute és Deleuze stílusfogalma azon a ponton szintén érintkezik, hogy éppúgy a szövegszerűségtől haladnak stílusfogalmuk kialakításában a nem-szövegszerüség

\footnotetext{
${ }^{241}$ Deleuze, Parnet (2016). p.8.

242 mouvement

243 sensation

${ }^{244}$ Deleuze, Gilles (1993.) Bégaya-t-il... in Critique et clinique, Paris, Les Éditions du Minuit p. 139.

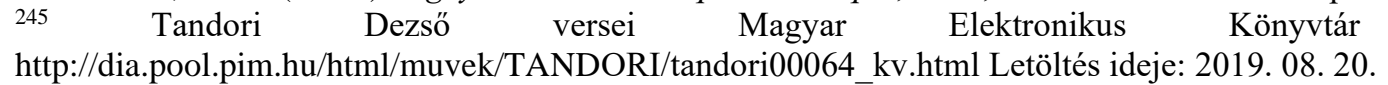
${ }^{246}$ Deleuze-Parnet (2016). p. 13-14.
} 
felé ${ }^{247}$, tehát irodalmi tapasztalataikból építik fel stílusfogalmukat. Viszont különböző eredményre jutnak. Deleuze a stílusfogalom kapcsán az alkotást nyelvi értelemben tételezi: „Ahhoz, hogy megértsük, mi is a stílus, el kell felejtenünk mindent, amit a nyelvészetről tudunk." A stílus ilyen értelemben a nyelvben felbukkanó dadogás, melyet ő „megnyilatkozás-elrendeződésnek” ${ }^{248}$ nevez. „Nem a beszéd, hanem maga a nyelv dadog.”249 Deleuze továbblép és a hebegést ${ }^{250}$ később elkülöníti a dadogástól ${ }^{251}$, de mindvégig a nyelv áll gondolatkörének középpontjában. Sarraute is irodalmi tapasztalataiból, a szövegszerüségből indul el stílusfogalma felé, de a nyelvtől elszakadva a stílust a parole, a diskurzus müvészi megoldásainak területén képzeli el. Deleuze soha nem fordult el a fabuláció, a szüzsé, a szereplők nyelvi megalkotottságának szükségességétől. A csaló és az áruló fogalmainak bevezetésével még egyfajta sajátos, rá jellemző, Greimas-éhoz hasonló aktáns-elméletet is létrehozott. ${ }^{252}$ Sarraute a szereplő stilisztikájában ezzel ellentétben tudatosan fordul el a hagyományos szereplőfogalom szerinti szövegszerü megalkotottságtól és a szereplöt arctalanított beszédjelenségként kívánja megvalósítani, mintegy elfolyatva szövegeiben.

A stílus Deleuze szerint az, ha kisebbségi módon használjuk a nyelvet ${ }^{253}$, azaz a többnyelvűség felvállalásával, szökés- vagy variációvonalak követésével megtörjük homogenitását. A dadogás, az újrakezdés, a többnyelvűség, többszöri megfogalmazáskísérlet, azaz a stílus túlmutat a szövegen. Deleuze, akárcsak Sarraute, elveti az írás tautologikusságát, Deleuze egyenesen „neurotikusnak” tartja, ha az írás önmaga céljává válik és benne az élet megaláztatik, megcsonkul. Mindkettejük számára a megszemélyesülés ${ }^{254}$ jelenti a stílus halálát.

A másik fogalom, amely összekapcsolja a sarraute-i és a deleuze-i stílusfogalmat, a sztereotípia. Deleuze La littérature et la vie [Irodalom és élet] címü esszéjében a sztereotípia formátlanításának folyamatáról ír: „a művész atléta az értelemben, hogy folytonos erőfeszítéseket tesz arra, hogy az általa megalkotott nyelvet kitolja annak határai felé" ${ }^{255}$. Az

\footnotetext{
247 Sauvagnargues, Anne (2005), Deleuze et l'art, Paris, PUF. Sauvagnargues Anne (2015), "Deleuze et les cartographies du style. Asignifiant, intensif, impersonnel" in Adnen Jdey (szerk.), Les styles de Deleuze, Paris, Les Impressions Nouvelles, p. 157-181.

248 Deleuze, Pernet (2016). p. 9.

${ }^{249}$ Uo.

${ }^{250}$ Uo. p. 73. balbutier, felfüggesztés, szuszpensz

${ }^{251}$ Uo. p. 73. bagayer, ismétlés, burjánzás, elágazás, eltérés

252 Uo. p. 38-39.

${ }^{253}$ kisebbségi-leendés. Uo. p. 10.

254 U.o. p. 11.

${ }^{255}$ Deleuze, Gilles (1993). "La littérature et la vie" in Critique et Clinique, Les Éditions de Minuit, Paris, p. 12.
} 
atléta az, aki a kettő-közöttiségben taszítja a nyelvet, lehetővé teszi, hogy a leendés áramába forduljon. Ugyanez, az eröfeszités fogalma Sarraute-nál is folyamatosan a müvészetről való beszéd része, és azt a folyamatot jelöli, amelynek segítségével az író az ismeretlen valóság érzeteit, mozdulatait, a szómögöttest beszédjelenséggé teszi. Az atléta, akár a sarraute-i erőfeszítést megtenni képes író, „fel tud fedezni a személyes látszata alatt valamiféle személytelen erőt, amely semmiképpen sem általánosság, hanem egyediség." ${ }^{256}$ A „,személyes maszkja"257 mögé betekinteni kívánó író képe tehát mindkét gondolatkörben jelen van. Sarraute ugyanakkor a szereplő arctalanítását a karakter teljes dekonstrukciójában oldja fel, miközben Deleuze nem feltétlenül emeli kritériummá az irodalomban az arctalanítás gesztusát, elfogadja a fabulációval együttjáró szereplöképzést, egyszerüen csak azt várja a szereplőt megalkotó írótól, hogy olvasáskor tudjuk „,vizionálni, „leendésekbe”, „,erőterekbe” belépni az irodalmi szöveg befogadása, a szereplő megismerése által. ${ }^{258}$ „A leendések a legkevésbé érzékelhetőek, olyan cselekvések, amelyek csak az életben lehetnek, és csak a stílus fejezheti ki öket." 259

A sarraute-i és a deleuze-i stílusfogalom közös mozzanata még az elrendeződés is, hiszen a dadogás folyamatában vannak megérkezések, újrakezdések, újrapróbálkozások, összeomlások az önkifejezésben mindkettőjük számára. A geofilozófiaa ${ }^{260}$ nem-hierarchikus fennsíkelmélete szerinti dinamikus elrendeződést pontosan a diskurzivitásból való kitekintés adja éppen úgy, ahogyan a tropizmus fogalmával is biológiai metaforával nyitja meg $\mathrm{N}$. Sarraute a szövegvilágok kizárólag nyelvi elrendezettségét a nem-nyelvi mozzanatok, a szómögöttes felé. A kartográfia, a földrajz és a geográfiai elrendeződések metaforikája áthatja mindkét szerző elméletét. Sarraute így ír:

„Ezek a dialógust előidéző megnevezhetetlen, apró mozgások Proust számára onnan, ahonnan ő nézi ezeket, ahhoz hasonlóak, ahogyan a térképész felette elrepülve szemléz egy területet, a vízfolyások örvényeit és hullámait ; nem látja és nem ábrázolja csak az óriás mozdulatlan vonalakat, amelyekké a mozgások összeállnak, a pontokat, ahol a vonalak egymásba érnek, keresztezik egymást vagy szétfutnak; felismeri közülük azokat, amelyeket már felfedezett és ismert nevükön nevezi öket: féltékenység, sznobizmus, félelem, szerénység, stb. ; leírja, osztályokba sorolja és megnevezi azokat, amelyeket ő fedezett fel; arra törekszik, hogy megfigyeléseiből általános elveket kovácsoljon. Ezen a

\footnotetext{
${ }^{256}$ Uo. p. 13. „En découvrant sous les apparentes personnes la puissance d'un impersonnel qui n’est nullement une généralité, mais une singularité".

${ }^{257}$ Uo. masque d'un personnel

${ }^{258}$ Uo. visions, devenirs, puissances

259 Duplay, Mathieu (2003). "Littérature mineur" in. Sasso, Robert, Villani, Arnaud (2003). Vocabulaire de Gilles Deleuze, Cahier no3. Printemps p.220. idézi Deleuze-től a Párbeszédeket „Les devenirs, c'est le plus imperceptible, ce sont des actes qui ne peuvent être contenus que dans une vie et exprimés dans un style."

${ }^{260}$ Uo. p. 329.
} 
hatalmas térképen nagyrészt még fel nem fedezett területek ábrázolódnak ki, amelyeket az olvasó elé tár."261

Sarraute-nál is megjelenik tehát a földrajz fogalmainak képpé formálása, az alázúzott szavak, és még számos más (sivatag, territórium, deterritorializálás) segítségével viszont Deleuze már terminológiát alkot. Ezzel kapcsolatban mindkét szerző stílusfogalmában azonos az a gondolat, hogy a nyelv, az önkifejezés, és különösen az irodalmi beszédmód alapegysége nem valamiféle gondolat, jelölö vagy jelölő-jelölt viszony, hanem az elrendeződés, vagy ahogy Sarraute nevezi, a tropizmus.

Visszatérő elem Sarraute-nál, akárcsak Deleuze-nél a stílus személytelensége, hiszen a szépirodalmi szövegekben a cselekmény, a tér, az idő narrativitásának lebontása óhatatlanul a szereplő feloldódásához, dezindividuációhoz vezet ${ }^{262}$. Deleuze számára a stílus rizomatikus, nem az egyén vertikális hierarchiája tükröződik benne, hanem a rizóma horizontalitása, variánsokból építkező elrendeződése. „A leendés nem rajtunk keresztül zajlik. A leendésben nincs múlt, nincs jövő, sőt jelen sincs, nincs történelem. A leendés inkább involúció: nem regresszió, nem is progresszió. Leend: azaz egyre józanabb lesz, egyre egyszerübb, egyre inkább sivatag, ám benépesített sivatag." ${ }^{263}$ Összefüggésbe hozhatjuk ennek kapcsán a deleuze-i redőzöttség ${ }^{264}$, fogalmát a Sarraute által kedvelt stílusformával, a gyakran névmási formában szövegszerüvé váló megszólaló beszédével. Ez a személytelen individuáció nem engedi, hogy a szereplő, a jellem, a karakter előtérbe kerüljön, hanem valójában bárki lehet a megszólalás alanya éppúgy, mint tárgya. Az individuációk sora redőzöttségben jelentkezik.

Deleuze úgy gondolja, hogy az érzékelés és a müvészi megformálás jelenlegi felfogása abból adódik, hogy az ember hajlamos a jelet az azt megjelenítő jeltárgyra vetíteni, a tárgynak tulajdonítva mindazt, amit a jel hordoz. Deleuze ugyanakkor elméleti zsákutcának tekinti azt a

\footnotetext{
${ }^{261}$ Sarraute (1956). "Conversation et sous-conversation" in L'Ere du soupçon p. 114. „Mais ces mouvements innombrables et minuscules qui préparent le dialogue sont pour Proust, á la place d'où il les observe, ce que sont, pour le cartographe qui étudie une région en la survolant, les vagues et les remous des cours d'eau; il ne voit et ne reproduit que les grandes lignes immobiles que ces mouvements composent, les points où ces lignes se joignent, se croisent ou se séparent ; il reconnaît parmi elles celles qui sont déjà explorées et les désigne par leurs noms connus: jalousie, snobisme, crainte, modestie, etc. ; il décrit, classe et nomme celles qu'il a découvertes ; il cherche á dégager de ses observations des principes généraux. Sur cette vaste carte géographique, représentant des régions pour la plupart encore peu explorées, qu'il déploie devant ses lecteurs."

${ }^{262}$ Sasso-Villani (2003). p. 77. désubjectivation: sujet sans identité, décentré, s'ouvre à la multiplicité de ses individuations possibles - a szubjektum elvesztésének folyamata: identitás, középpont nélküli alany, aki nyitott a különféle lehetséges individuációkra

${ }^{263}$ Deleuze-Parnet (2016.) p. 29.

${ }^{264}$ Sasso-Villani (2003). 282-284. le pli - a redő, a redőzöttség fogalma a sivataggal kapcsolatos képrendszerből került Deleuze metaforikájába. Nem függetleníthetően valamiféle szabadságfogalomtól, a redő valamiféle összeállás, pillanatnyi létmód, amely az aioni végtelenből jön, abba tart, oda-visszaáramlásokban létezik. Főleg az Érzet logikájából idézve a fogalmakat: egyedi pontok sorozata (séries de points singuliers), sorozatszerü individuációk (singularités sérielles)
} 
szándékot, hogy a tárgyat és a jelet egy lapon említsük, és erre hozza fel az irodalmi értelmezés példáját ${ }^{265}$. A jeltárgy és a jel azonosításából kiinduló kritikai nézőpont nem tesz mást, mint „rámutat” a jelre; megvizsgálja és leírja, és hiszi, hogy így meglelheti a jeltárgy titkát. Összetéveszti a megfogalmazható jelentéseket a valódi értelemmel. Ha a jelet leválasztjuk a jeltárgyról, mondja Deleuze, akkor tudjuk valóban dekonsturálni a hagyományos mimetikus reprezentációs modellt. „Ahogyan egyre inkább emelkedünk a művészet szintjére, a jel és a jelentés kapcsolata úgy válik egyre közelebbivé, bensőségesebbé. A müvészet végül is a testetlen jel és a spirituális jelentés legszebb egysége.” ${ }^{266} \mathrm{Ez}$ a fajta gondolatmenet szinte megegyezik Sarraute-éval. „A müvészet, abban a hivatásában, hogy a lényeget kívánja megragadni, az egyetlen, ami képes megadni számunkra, amit az életben hiába kerestünk." ${ }^{267}$ A jelek értelmezésének tanulmányozása az „egyiptológus gyakornokot" csalódással tölti el, hiszen a jeltárgyak büvöletében néha megfeledkezik a valódi értelemről. Sarraute ugyanezt a gondolatot más szavakba öntve fejezi ki: „zavaró rövidlátásról” beszél, annak a zavaró rövidlátásáról, aki a tárgyak bűvöletében „,mindent annyira közelről vizsgál, hogy így nem lesz alkalma messzebb látni az orra hegyénél”. 268 Deleuze, akárcsak Sarraute, az ellen az „objektivitás” ellen harcol, amely megvakít és kollektivizál. A jel és a jeltárgy különválasztása magában hordozza a lehetőséget, hogy az ember el tudja kerülni az objektivitás és a kollektivizálás csapdáját. Ez a megkülönböztetés teszi az embert emberré, egyéniséggé, teszi számára lehetővé a „lényeg” elérését, megragadását. A lényeg bennünk van, létünk börtönébe zárva, begubózott a lelkünkbe, megadja egyéniségünk, emberi voltunk lényegét. „Csak ebben a lélekbe zártságban létezik, ugyanakkor nem függetleníthető a lét ismeretlen részétől, amelyet önmagával együtt lelkünk mélyén ő hordoz”269. Sarraute Deleuze-höz hasonlóan „az ismeretlen valóság” megragadásáról beszél, amelynek feltárása szerinte a regényíró feladata ${ }^{270}$.

Hogyan fogalmazható meg tehát ennek a kontextusából kiragadott esztétikai jelnek az időbelisége, hogyan lehet meghatározni az „óriásira felnagyított jelen” pillanat időbeliségét? „Az éppen születőben lévő történések, még nem megnevezhetőek, még el sem érték a tudat határát, ahol közhelyekbe merevednek, ezek adják valamennyi könyvem gerincét. Folyamatos

\footnotetext{
265 Deleuze-Parnet (2016). p. 44.

${ }^{266}$ Deleuze, Gilles (1964). Proust et les signes Paris, Presses Universitaire de France p. 50. „(...) à mesure qu'on s'élève jusqu'à l'art, le rapport du signe et du sens se fait de plus en plus proche et intime. L'art est la belle unité finale d'un signe immatériel et d'un sens spirituel."

${ }^{267}$ U.o. p. 53.

${ }^{268}$ Sarraute, Nathalie (1956). p. 19.

${ }^{269}$ Deleuze, Gilles (1964) p. 56-57.

270 Sarraute, Nathalie (1996). "Roman et réalité", in CEuvres complètes p. 1644.
} 
átalakulásban vannak, szüntelen leendésben." ${ }^{271}$ Ez a meghatározás mintegy Gilles Deleuze szavainak visszhangja, aki szinte ,a lényeg zárt világa mindig a Világ mint olyan, a teremtődő univerzum folytonos kezdete, az abszolút radikális kezdet." ${ }^{272}$ Az idő itt és Sarraute-nál sem, semmiképpen nem egyfajta kifejthető, lefolyással bíró, elkülöníthető folyamatokból és dimenziókból álló idő. Nincs lefolyása, még ritmusa sem. A sarraute-i szöveg a világ teremtődésének frissességét lélegzi, és sorról sorra elsődleges jelek közvetítéséből építkezik. ${ }^{273}$

Nathalie Sarraute tehát „gyanakvással” szemléli a mimetikus reprezentációt, Gilles Deleuze pedig elméleti dekonstrukcióját kísérli meg a jel és a jeltárgy szétválasztásával. A kontextusából kiragadott jel időbelisége a teremtődés pillanatában érhető tetten. A tiszta jel esztétikai megragadása a lehetőség Deleuze szerint az irodalom új alapokra helyezésére. Ez az elképzelés nem áll távol az autotelikus irodalmi koncepciótól, az önmaga számára elegendő nyelvi elképzeléstől, amely megjelenik a Jakobson-féle kommunikációs funkciók között az esztétikai funkciónál, de Roland Barthes írásaiban is. De Nathalie Sarraute, ahogy mondja: „nem filozófus”274. Érdeklődik a nyelv iránt, a nyelvvel dolgozik íróként, de elméleti írásai nem megelőzik szépirodalmi kísérleteit, hanem követik azokat, sőt, inkább azoknak egyfajta leírásai, utórezgései. Melyek azok a formák, amelyekben ezek a „teremtődésen kapott történések”, ebben az „óriásira nagyított jelenidőben” megjelennek a sarraute-i szövegekben?

Deleuze szerint a valódi müalkotás lényege nem a tárgyalt téma tudatos és akaratlagos megformálása, nem jelentéses szavak sora, hanem a tudattalan tartalmak, az akaratlanul színre lépő archetípusok, ahol a szavak elnyerik valódi jelentésüket és életre kelnek. A tárgy átlelkesítése, a téma spirituális mélységekkel való megtöltése és anyagi, testi, földi valóságoktól elkülöníthetősége maga a „stílus”. A stílus tehát metafora, metamorfózis. ${ }^{275}$ Sarraute szintén abban lát lehetőséget, hogy képes-e megragadni a születőben lévő pillanatot, a kontextusából kiragadott jelet úgy, hogy nem képez eseménysort, nem állít hősöket, mert azzal csak a való vagy belső élet vagy egyfajta fikciós, elképzelt valóság modellálását, ábrázolását lenne hivatott megvalósítani, hanem a stílus, a nyelvi megformálás lehetőségeit kívánja kiaknázni.

\footnotetext{
${ }^{271}$ Sarraute, Nathalie (1996). "La littérature, aujourd'hui" in Euvres complètes, p. 1662.

${ }^{272}$ Deleuze, Gilles (1964) p. 57.

${ }^{273}$ Uo. p. 58.

${ }^{274}$ Sarraute, Nathalie (1996). "Roman et réalité", in Euvres complètes p. 1643.

${ }^{275}$ Deleuze, Gilles (1964). p. 60.
} 
„Az író törekvése, amelynek segítségével a látható valóság elsődlegességét hivatott megtörni, hogy segítse feltörni az érintetlenség, újdonság erejével ható mozzanatokat, és úgy önteni formába, úgy újraszervezni, úgy formálni öket modellé, hogy az eredményt müvészi alkotásnak lehessen nevezni. A mű szerkezete, az író stílusa árulkodik ennek az erőfeszítésnek a minőségéről.”276

Az anti-reprezentációra való törekvést képviselő scripteur erőfeszítése a stílusban ölt testet. Az író, éppúgy, mint a filozófus a nyelvben találja meg a megoldást arra a problémára, hogy hogyan lehet érzékeltetni a jeltárgytól elkülönített jelet, az eseménysorból kiragadott eseményt, a kontextusból kiemelt tropizmus időbeliségét. A stílus az, ami lehetővé teszi „a születés fázisában lévő történés” megragadását az irodalmi szövegekben. Az Új Regény egyik kedvelt írói módszere például a mise en abyme ${ }^{277}$. A mü egyrészt szól valamiről, másrészt tartalmazza saját létrejöttének történetét. A szöveg egésze mellett fellép egy vagy több betét, belső történet is. A beékelés az egységesítés ellenhatásaként jön létre (az egységesítés a kronologikus elbeszélés vezérfonala, és az olvasó aktivitásának is egy fontos törekvése). Mi is a beékelés? Analógia, tükör, amelyet a szövegegész elé tart a betét? A szövegegész metonimikus egységének megtörése metaforikus funkciójával. Tükörjáték, végtelenítés: a lezártság lehetőségének kiküszöbölése.

\section{IV.4. A stílus elsődlegességének és a szereplő dekonstrukciójának összefüggése}

Látható, hogy a tartalommal szemben a nyelvi megformálás fokozatosan hangsúlyos előtérbe helyeződése hogyan gyakorolt nyomást a stílusfogalom tematizálására. Ahogyan a szépirodalmi alkotói folyamat nyelvi, formai vetülete domborodik ki, úgy válik a szereplő megalkotottságának is prioritásává annak szövegszerüsége. Sarraute-nál az én feloldódása elengedhetetlen a történet hátterében húzódó szómögöttes, a tropizmus feltárásához, és ez az énabszorbció a deleuze-i stílusfogalomnak is a velejárója.

A sarraute-i szereplö-foglalat felépítésében azért van szükség az arctalanítás gesztusára, mert az arc az én, a szubjektum és a nyelvi jelentésesség hordozója ${ }^{278}$. A Mille plateaux 5. fejezetének azért Année zéro [Nulladik év] a címe, mert arra utal, hogy az arc, az arcadás gesztusa a krisztusi arcban nyeri el forrását. Arcot adunk a társadalmi, hierarchikus

\footnotetext{
276 Sarraute, Nathalie (1996). "Roman et réalité", in CEuvres complètes p. 1644.

277 Angyalosi (1996). p. 101. abyme: feneketlen mélység

278 Deleuze, Gilles, Guattari, Félix (1980). "Visagéité, année zéro" in Mille plateaux; Capitalisme et Schizophrénie 2 5. fejezet, Les Editions de Minuit. p. 205-234 Elérhető: http://www.philophil.com/philosophie/ représentation/Analyse/deleuze-visage.htm Letöltés ideje: 2020. 01. 14.
} 
viszonyainknak, arcot adunk az érzéseinknek, ezzel elhelyezzük a kommunikációnkat a nyelv jelentéses rendszerében. Létrejön a szubjektum - Deleuze a szubjektumnak ezt a kifejlődését úgy nevezi, hogy fekete lyukak keletkeznek a fehér falon - és létrejön a jelentésességgel összefüggő köznyelvi, mindenki számára érthető beszéd. Az arcadás nem a fejjel függ össze deleuze-i elméletben, hanem absztrakt gépezete a teljes testet felülkódolja ${ }^{279}$, azaz átírja létünket, lényegünket, dehumanizál. Az arctalanítás azt jelenti, hogy láthatatlanná válunk, érzékelhetetlenek leszünk, bujdosókká válunk ${ }^{280}$, a sarraute-i tropizmus közegében azt állíthatjuk, hogy az arcvesztés növény-leendésben valósul meg. A fehér fal átlyukasztása szimbolizálja Deleuze-nél az arcadástól való elmenekülést. Ugyanez az arctalanító-menekülő mozzanat Sarraute-nál is megjelenik a XXI. tropizmusban: „hallgatni; nézni őket; és pont a nagymama szenvedései alatt felugrani, óriási lyukat ütni, egérutat nyerni a megrepedt közfalon át és ordítva futni a házak között, amelyek kikucorodva leskelődnek a szürke utcák hosszán, mindegy, csak menekülni innen." Deleuze hasonló megfogalmazással él: „Átszakítottam a falat (...), a szemeim semmire sem jók, hiszen csak ismert képet küldenek felém." 281

Deleuze az arctalanítás szükségességét a szubjektumtól és a jelentéstől való függetlenedésben látja ${ }^{282}$. A nyelvi jelentés által hordozott dichotómiáktól kell megszabadulni (férfi-nő, gazdag-szegény). Ez akár azt is jelentheti, hogy a normalitástól való eltérésként értelmeződhetnek mondataink, eljárásaink. Sarraute számos szépirodalmi művében van jelen az őrültség gondolata, érzete, félelme, gyanúja. A XXII. tropizmus személytelen il alakja szinte önironikusan próbálgatja végig a normalitáshoz köthető hóbortokat, hogy arctalan, tropizmikus, csak rá jellemző érzetkötegeit leplezze - fél attól, hogy ha napvilágra kerülnek, bolondnak tarthatják. Az Un portrait d'un inconnu [Egy ismeretlen arcképe] elbeszélöjét is specialistához küldik. Később megállapítja, hogy az üléseknek nem sok értelme volt saját szempontjából, de a rokonok és a barátok megnyugodhattak. Egész kötet, Disent les imbéciles [Mondják a bolondok] feszegeti, milyen módokon titulálják az emberek egymást abnormálisnak. A szubjektív választás stilisztikája, a nyelvi elemek közül a jelentés és a kifejezés célja szerinti, a szubjektumhoz köthető válogatás nem más, mint arcadás. Ennek a stílusnak a leépítésére, az arctalanításra van szükség ahhoz, hogy a szereplök ne üzenetek

\footnotetext{
${ }^{279}$ U.o. code corporel, surcodage des parties décodées

${ }^{280}$ U.o. „défaire le visage et les visagéifications, devenir imperceptible, devenir clandestin”

${ }^{281}$ U.o. „J'ai brisé le mur (...), mes yeux ne me servent à rien, car ils ne me renvoient que l'image du connu." Sarraute-nál is számos alkalommal szerepel a face connue - face inconnue de la réalité / a valóság ismert és ismeretlen vetülete

${ }^{282}$ U.o. l'asignifiant, l'asubjectif
} 
közlésének eszközeként épüljenek fel, hanem válhassanak érzetegyüttesek foglalataivá, foglalat-szereplőkké.

„A művészet nem cél, hanem annak az eszköze, hogy ráhagyatkozzunk az élet szökésvonalaira, azaz valamennyi valóság-leendésre, amelyek nem egyszerüen a müvészetben jönnek létre vagy abba menekülnek; hanem a müvészet segítségével áthelyeződnek az arctalan, azaz jelentés nélküli és egyéniség nélküli dimenziókba." 283

Ugyanitt Deleuze a kereső fejekről beszél, amelyeknek az arctalanításban van szerepe szökésvonalakat, újfajta leendéseket indukálnak, mindenfelé rizómákat hoznak létre.

Az irodalmiság titka az a különös oda-vissza hatás, ami a szöveg és a valóság között folyamatosan fennáll. A Sarraute-szövegekben a klasszikus, arccal ellátott hőstől való elfordulás, eltávolodás és a nyelvi megformálás által létrehozott arctalanított, deszubjektivizált szereplö-foglalat felé fordulás a jelentésesadás teljes felszabadítása révén esztétizál. Ezt az esztétikai gyönyört nem a reprezentációban, az ábrázolás illúziójában és hitelességében keresi, hanem a kódban. Az ebben a folyamatban rejlő feszültséget nevezzük $a z$ arctalanitás stílusának. Az eltávolítás gesztusa tehát a stílusra helyezi a hangsúlyt, amennyiben a hős személyszerü felépítettségétől (vagy akár a cselekmény, az időkezelés hitelességétől) elhatárolódik, eltávolodik és az itt és mostot, a pillanatot stilizálja felfüggeszti az esztétikai célú ábrázolás szerkesztésének, sűrítésének hagyományos eszközeit. $\mathrm{Az}$ ábrázolt tárggyal való azonosulás ellehetetlenítése ${ }^{284}$ az alkotás módrája, folyamatára irányítja figyelmünket.

Az írás Sarraute esetében ez a sajátosan stilizált beszédmód, sem nem epikus alapvetően, sem nem lírikus, mégis mind a két meghatározás érvényes rá. Lírai abban az értelemben, hogy a koherens szövegvilágot létrehozó epikus szöveggel szemben kibillenti az írást a kimondhatóság kényelmi helyzetéből. Elbizonytalanít, keresi a szavakat, ezért megáll, ismétel, s ez mintha sajátos ritmust adna a prózaszövegnek ${ }^{285}$. Ugyanakkor Sarraute életmúve nem csak formailag, hanem tartalmilag is hordozza a hőstől való eltávolítás gesztusát. Például Gyerekkor címü önéletrajzi regényében a gyermek nézőpontja, az ártatlanság optikája

\footnotetext{
${ }^{283}$ U.o. "L'art n'est jamais une fin il n'est qu'un instrument pour tracer des lignes de vie c'est à dire tous ses devenirs réels qui ne se produisent pas simplement dans l'art, toutes ses fuites actives qui ne consistent pas à fuir dans l'art, à se réfugier dans l'art; mais [à se transporter avec art et grâce à l'art] vers le régions de l'asigifiant de l'asubjectif et du sans visage."

${ }^{284}$ Julia Kristeva fogalma in La chair des mots. Elérhető: http://www.kristeva.fr/la-chair-des-mots.html (Letöltés ideje: 2019. 07. 06.) „désidentification” - az identifikáció ellehetetlenülése adja minden absztrakt müvészet alapját.

${ }^{285}$ Maulpoix, Jean-Michel. (2002), Le bout de la langue, A propos de Nathalie Sarraute, Elérhető: http://www.maulpoix.net/Sarraute.html (Letöltés ideje: 2019. 07. 06.)
} 
láthatóvá teszi a hazugság, az álca, a sztereotípia valóságát és minden kétséget kizáróan sugallja az attól való erkölcsi távolságtartás igényét.

Az elsődleges alkotói módszer ennek elérése érdekében a kihagyás, az utalás, a klisék, sztereotípiák mögött meghúzódó megnevezhetetlen, kimondhatatlan, implicit tartalmak nyelvi, stílusbeli finomságokkal való érzékeltetése. A szereplök nem jellemükben felépítettek, hanem csupán stílushatásokkal érzékelteti jelenlétüket. Nyelvhasználatában mindazt a verbalizáció előtti nyelvi szintet igyekszik megragadni, amelynek lényegi mozzanata pont ez a kimondatlanság. A szereplő stilisztikáját elsődleges szövegvilágában, a tropizmusokban kívánom először vizsgálni.

A „,beszéd” fogalma, a szóbeliség, a szóbeli megnyilatkozások és dialógusok ezekben a sajátos rövidszövegekben központi szerepet játszanak. Conversation et sous-conversation [Szó és szómögöttes] címü esszéjében. ${ }^{286}$ a hétköznapi dialógus szóbelisége elsősorban nem más, mint a létezés ontológiai kerete: „ezeknek a belső drámáknak a forrása a támadások, győzelmek, visszavonulások (...), nagylelkű elengedések, alázatos önátadások sora: hiszen mindezekben egy közös van: hogy szükség van hozzájuk egy társra. Egyedül nem megy.”287. Végül is, minden, ami létezik, azért van, mert kapcsolatban van egy önmagán kívül eső entitással, személlyel, dologgal, valamint minden, ami történik, két személy között történek: minden kapcsolat és dráma, ezért a szövegben párbeszéd, szavak idézése. A világ létezése magában hordozza a polaritást; a beszélgetések sokszínüsége alkotja meg, valamint alkotja újra és újra a realitást.

Önéletrajzi regényének, a Gyerekkornak is ez az alkotói elv adja fő struktúráját, a szóbeliség itt alkotói módszerként jelenik meg. Beszélgetést sugall a szöveg „egy elképzelt társ" 288 és az írónő között. Az író saját emlékezete szerint ebben az elképzelt beszélgetés volt a „legértékesebb regénytéma” ${ }^{289}$, mely valaha foglalkoztatta. A Gyerekkor narrációja így nem egyéni teljesítmény eredményeként létrejött szövegformálásként tünik fel, és nem is az alkotó által létrehozott változhatatlan formában létező mondatokként, hanem drámai jelleget ölt, sőt, magán viseli a szerző és „mása” közötti titkos párbeszéd nyomát. Változó, hullámzó, drámai: azaz szóbeliségre utaló jegyeket hordoz.

\footnotetext{
${ }^{286}$ Sarraute, Nathalie (1956). L'ère du soupçon, Paris, Gallimard p. 99-117.

${ }^{287}$ U.o. p. $99-100$.

${ }^{288}$ U.o. p. 100.

${ }^{289}$ U.o. p. 100.
} 
Ennek a titkos párbeszédnek a szövegben való megjelenítése tehát az, ami a Gyerekkor legalapvetőbb „narratív sajátossága” ${ }^{290}$ lesz: a belső párbeszéd. Végül az sem mellékes, hogy a szóbeliség rögzítése olyan írói eljárássá válik a „modern regényben, amely az elmaradó cselekmény helyébe lép”291. Mivel „,ez a leginkább értékes írói eszköz”292, ,a szóbeliség beemelése az irodalomba olyan nélkülözhetetlen erényekkel rendelkezik, amelyek egyedül képesek a mélyben magukba fogadni, megóvni, majd az írott szöveg felszínére hozni azokat a tudati mozgásokat, amelyek egyszerre türelmetlenek és szégyellősek." ${ }^{293}$ Ha nincs cselekmény, nincsenek történések, az író csupán ezekre támaszkodhat.

A beszéd így szerkezeti elemmé válik, narrativ módszerré (belső párbeszéd) és a függő beszéd mint alkotói eljárás így teszi szellőssé Sarraute hullámzó, mozgásban lévő szövegeit. Nem szöveg-kagylók megalkotására tesz kísérletet a szerző, hiszen az az írói technika, amely a felidézésen alapul, három lépcsőben bontakozik ki, és mindig a párbeszéd van a forrásánál. Ebben a párbeszédben a szavak, mire a felszínre törnek és elhangzanak, magukban hordozzák az anyai ringató gesztusok igézetét, hiszen a kommunikáció értelmét mindig a beszéd előtti fázis valóságából nyerik. A nyelvi megformálás a forrásánál ragadja meg a szóbeliséget: ahol megszületik, a dadogásban, ${ }^{294}$,az életszerü kis valóságdarabok” ${ }^{295}$ a csendben, a zeneiségben öltenek testet és lehetővé teszik a szerző számára, hogy mintegy keresse a szavakat.

Nem hagy teret a képzeletnek. Fikció helyett hitelesség van, életes érzékeltetés. „Csak ha elképzelhetném, könnyü lenne.”296 - írja egy helyen. De nem képzeli el, nem képzelheti el, hiszen pontosan az az önmagával és az olvasóval szemben támasztott elvárás, hogy ő maga életre írja, a befogadó pedig életre olvassa a pillanatot. Ezért van az, hogy a sarraute-i szöveg a beszéd ihletettségéből táplálkozik. Nyelv helyett beszéd: a nyelv egyensúlyi helyzeteket produkáló rendszer, jelrendszer, melyet a stílus „,csődközeli, összeomlás szélén álló”297 helyzetbe hoz. Az irodalmi beszédmód a beszéd, a nyelvhasználat „,külső vetülete, de nem a nyelven kívül van" ${ }^{298}$. Ez azt jelenti, hogy az irodalmi beszédmód a határáig sodorja a nyelvet, és még azon is túl, a zeneiségig, ahol a szavak formálódnak és még csupán

\footnotetext{
${ }^{290}$ Groupe $\mu$ (1982). Rhétorique générale, Éditions du Seuil, p. 187-188.

${ }^{291}$ Sarraute (1956) p. 104.

292 U.o. p. 104.

293 U.o. p. 102.

${ }^{294}$ Deleuze (1993). p. 135-143.

${ }^{295}$ Sarraute, Nathalie, Enfance, Paris, Gallimard, 1995, p. 9.

${ }^{296}$ U.o. p. 232.

${ }^{297}$ Deleuze (1993). p. 137. en état de boom, proche du krach

${ }^{298}$ U. o. p. 141. le dehors du langage, n'est pas extérieure au langage
} 
„,csendként” ${ }^{299}$ értelmezhetők. Ennek a csendnek, zeneiségnek a tapintható vetülete amikor az írás alakját ölti, dadogásként ragadható meg. Sarraute szövegének kettősségét kívánom feltárni: a szöveg nyelvi szempontból átgondolt és pontos megformálása a beszédet, a megszólalást a gyökerénél ragadja meg: a dadogásnál, a „gyermekkoránál”.

A szereplöket sem fiktív módon építi fel, nem jellemet, külső-belső tulajdonságokat rendel hozzájuk, hanem megszólalásaikat a születő szavak, mondatok, a keletkezés forrongása hatja át. „Születőben lévő beszédüket a maga gyermeki mivoltában, őrült dadogásában ragadja meg” ${ }^{300}$. „Ezek a kis darab még élő valamik” ${ }^{301}$ a szereplőkön átszürve érkeznek meg az olvasóhoz. Tudunk róla, hogy Sarraute fel is olvasta számos szövegét, hanganyagokat hagyott hátra. A mondás, a kimondás, a beszélt nyelvi fordulatok, a beszéd idézése végig elsődleges fontosságú müvészetében. Sőt, nem csak a megszólalásokat idézi fel, hanem mindazt, ami egy-egy megszólalás mögött, annak hátterében van, ezek a szómögöttes tartalmak.

\section{A tropizmus elevene}

„A tropizmus kifejezés a biológiai szakszavak közé tartozik. Az élőlénynek azt a reakcióját jelenti, amely végül valamerre való irányulásban ölt testet, $\mathrm{s}$ amelynek kiváltó oka valamiféle fizikai vagy kémiai behatás. Ez a reakció alakíthatja pozitívan vagy negatívan az élőlény további fejlődését, annak függvényében, hogy a kiváltó ok vonz vagy taszít (pl.: a fény vonzáskörébe kerülő rovarok halála, a hideg elől menekülő fecskék túlélése). Nathalie Sarraute ezt a képet alkalmazza az emberek világára, és úgy értelmezi, mint végtelenül finom mozgássor (akár lelki, akár fizikai vagy verbális), meglódulás vagy visszahúzódás, megkönnyebbülés vagy megriadás, keserüség vagy elégedettség, amit mások beszéde, szavai engednek megszületni tudatunk legvégső rejtekében. Így reagálunk egy-egy szóra, hanghordozásra, hangulatra vagy gesztusra."302

Nathalie Sarraute 1939-ben adja ki Tropizmusainak első változatát. Ezekben a rövidprózákban olyan, a tudat számára hozzáférhetetlen tartalmak megragadását tủzi ki célul, amelyek alig vagy egyáltalán nem kerülnek társadalmi jelenlétünk szintjére, és létezésük, illetve jellegük kizárólag utalásokból, képsorokból derül ki a megfigyelő számára. Már ebben az első mủvében elfordul a klasszikus prózaírói formavilágtól, és az elbeszélés, a leírás, illetve a dialogikusság szövegtípusainak sajátos keverékével létrejövő egyéni műfajt teremt. Nem vesznek tudomást a müről. Sem a kritika, sem az olvasók nem karolják fel, észrevétlenül lappang egészen 1957-ig, amikor is újra megjelenik, hat további darabbal bővített kiadásban. Ekkor már, feltehetően a pár évvel előbb íródott Martereau-nak és az egy évvel korábban megjelent $L$ 'Ère du soupçonnak köszönhetően érdeklődést keltett.

\footnotetext{
299 U.o. p. 142.

300 Bompiani (2000) p. 47. "La parole est prise dans son enfance, dans son bégaiement affolé"

${ }^{301}$ Sarraute (1995) p. 9. "petits bouts de quelque chose d'encore vivant"

302 Savéan, Marie-France, Dossier in Sarraute, Nathalie (1995) p. 294.
} 
Sarraute már első gyüjteményes kötetében a klasszikus regénynarratíva szereplőhasználatának átértékelésére és meghaladására törekszik, de később elméleti szerzőként és regényíróként is egyaránt ezen dolgozik. Elsősorban a szöveg stílusának megújítására és a lét nem kimondott, elhallgatott, a verbális készségeinkkel nem, csupán az érzékeinkkel, sőt, a hatodik érzékünkkel felfogható valóságok megragadására tör. Sarraute tropizmusaiban egymásra csúsztatja az ábrázolás hagyományos, eltérő hatáselemeit, hogy szükségünk legyen a legkülönbözöbb érzékeinkre a szövegek befogadásakor. Nem feltétlenül láttat, amikor leírást alkalmaz, és nem is a hallásunkra apellál, amikor szavakat idéz. Mintha egész valónkkal kellene befogadnunk a leírtakat, érzékeink mindegyike elkülöníthetetlenül mozgásba kell, hogy lendüljön.

Deleuze haptikus látásfogalmával ${ }^{303}$ lehet rokonítani Sarraute törekvését, hiszen mindkettő lényege, hogy „kiüzi magából a figurativitást és az elbeszélést is, hogy egyre közelebb kerüljön egy tiszta állapotában létező festői tényhez, amelyben már nincs semmi elmesélni való. Ez a tény a látás haptikus funkciójának konstitúcióját és rekonstitúcióját jelenti." ${ }^{304}$ Az érzet logikájában Deleuze a későbbiekben tovább taglalja, hogy

„maga a látás fedez fel önmagában egy tapintó funkciót, amely az ő sajátja és csak hozzá tartozik, és különbözik optikai funkciójától. Ez esetben azt mondhatnánk, hogy a festő a szemével fest, de csak annyiban, amennyiben a szemével tapint. S ez a haptikus funkció nyilvánvalóan közvetlenül és egy csapásra is megjelenhet a maga teljességében"305

Deleuze látásmódja szerint az alkotás haptikus funkciója akkor lép életbe, amikor a művészet „harmadik szeme” által „,megragadjuk az elevenséget”, mintegy az itt és most létező természet alapján hozzuk létre alkotásunkat ${ }^{306}$. „Mintha vizuálisan meghaladtuk volna a taktilis és az optikai kettőségét a (...) haptikus funkciónak az irányában.”307

A tropizmus mindaz a Sarraute-univerzumban, ami a hagyományos prózai müvekben a cselekményvezetés, a szereplő, a kronologikus időkezelés. Ezek mindegyike helyett áll. „A

\footnotetext{
${ }^{303}$ Riegl, Alois (1989). A későrómai iparmüvészet ford. Rajnai László. Corvina, Budapest, p. 25. „A haptikus, mely a görög hapto (tapintani) szóból származik, nem külsődleges viszonyt jelent a szem és a tapintás között, hanem „a tekintet egy lehetőségét”, egy olyan látást, amely különbözik az optikai látástól; az egyiptomi müvészetet letapogatja a tekintet, mindig közelről kell nézni, és ahogy Maldiney mondja, ,a tér közeli zónájában a tekintet mintha érintené, ugyanott érzékeli az alakot és a hátteret"

${ }^{304}$ Deleuze, Gilles (2014). Francis Bacon. Az érzet logikája, ford. Seregi Tamás, Atlantisz Kiadó, p. 71.

${ }^{305}$ U.o. p. 82.

306 Schein Gábor: Kezdés Elérhető: https://scheingabor.wordpress.com/2010/03/19/hello-vilag/ Letöltés ideje: 2019. 11. 04. a szerző haptikus látás segítségével rögzíti a kreativitás pillanatát: „Hallani akarom a robbanás zaját. / Én nem a szememmel, az ujjaimmal / látok. (...) / nem a formák féléber álmát akarom, / a tárgyakból torkolattüzként kicsapó / erőt, azt a megállíthatatlan pillanatot, / amikor még nyugodt a táj, de már / elszakadtak a tartókötelek, amikor még / semminek nincs neve, de már minden / beszél, minden teremni kezd.”

${ }^{307}$ Deleuze (2014). p. 85.
} 
tropizmus ritmus, maga a sarraute-i valóság." ${ }^{308}$ A társadalmi körülmények és helyzet realitásához a hétköznapi beszédböl elvont sztereotípiák és klisék kötik Sarraute prózai szövegeit. Ami ugyanakkor valóban írásainak gerincét adja, a szerkezet lényegét, az a tropizmus, amely az ember lélek mélyének csendjét szólaltatja meg, kizárólag stilisztikai eszközökkel, nem várva fogalmi megértést az olvasó részéről. „Ezek a mozgások soha nem mutatkoznak közvetlenül, mindig bensőnkbe rejtett a létezésük, csak következtethetünk rájuk a beszélgetések, valamint a felszín, a lehető legbanálisabb cselekedetek szemlélése alapján.” ${ }^{309}$ Maga a megírás és az alkotói célnak megfelelően az olvasás is a tropizmus esetében a lélek csendjében történik meg. A hiányszó szereplőket, cselekményt és időszerkezetet tudatosan klisékkel helyettesíti a szerző, abból a célból, hogy ne vonja el az olvasó figyelmét a már-már testileg átélhető érzetekről ${ }^{310}$, amelyek a tropizmus lényegét adják $^{311}$. Ezért van az, hogy a tropizmus-olvasó aktív részese a megértésnek, bár nem a jelentés megragadása, kialakítása, az értelmezés szerepkörében, hanem egyfajta átélést vár el tőle az író.

A tropizmus „önkéntelen válaszreakció”312, amelyet a szerző által „,névtelen, élő anyagnak" ${ }^{313}$ nevezett érzet ritmikus mozgása ad. Sarraute hangsúlyozza, hogy a tropizmusok az emberi létezésnek azt a szintjét képviselik, amelyek függetlenek mindenfajta nemi, nemzetiségi identitásunktól, valamint szociális hovatartozásérzésünktől. A tropizmikus érzetek és lelki mozdulatsorok alapvetően neutrálisak ${ }^{314}$. Ez a semlegességet feltételező poétika megjelenik a szépirodalmi alkotásaiban is. Több művének felütésében már-már ars poétikai szándékoltsággal vezeti be az olvasót a tropizmusok világába. A Tropizmusok első része, a babák pislogásától megigézett járókelők hipnotikus rácsodálkozása értelmezésem szerint metaforikusan a klasszikus regénynarratíva szereplőjének és olvasójának találkozására utal. A befogadót mintegy megbabonázzák a megkonstruált regényvilág szereplői, ám igazából nem tudnak találkozni velük, hiszen üvegvitrinek választják el őket egymástól.

\footnotetext{
${ }^{308}$ Lee, Mark (1996). "Tropismes : le réel comme rythme de l'histoire" in Le rythme : littérature, cinéma, traduction Volume 29, numéro 1, été 1996. Elérhetö: https://id.erudit.org/iderudit/501143ar Letöltés ideje: 2020. 01. 04. „Le tropisme est rythme, l'endroit du réel sarrautien.”

309 Bondy, François "Conversation de François Bondy avec Nathalie Sarraute" in Cranaki, Mimica, Belaval, Yvon (1965). Nathalie Sarraute, Gallimard p. 214. „C'est que ces mouvements ne se montrent jamais directement, ils sont toujours internes, cachés, on ne peut que les deviner á travers la surface, á partir de nos conversations ou de nos actions, des actions tout à fait banales."

${ }^{310}$ Sasso-Villani (2003). p. 130. Deleuze: l'espace lisse est associé au nomadisme, au devenir et à l'art haptique Deleuze-nél a sima tér fogalma asszociálódik a nomádsággal, a leendéssel és a haptikus művészettel in

${ }_{311}$ Amossy, Ruth et Herschberg-Pierrot, Anne (1997), Stéréotypes et clichés, Paris, Nathan. p. 284-289.

312 Rykner, Arnaud (1991). "Entretien avec Nathalie Sarraute" in Nathalie Sarraute, Paris, Seuil (Les Contemporains), p. 153-183. p. 170. réaction incontrôlable

${ }^{313}$ Sarraute (1956). p. 9., 13. matière anonyme, substance vivante

${ }^{314}$ Benmussa, Simone (1987), Nathalie Sarraute, Lyon, La Manufacture. p. 140-141.
} 


\begin{tabular}{|c|c|}
\hline $\begin{array}{l}\text { Une quiétude étrange, une sorte de } \\
\text { satisfaction désespérée émanait d'eux. Ils } \\
\text { regardaient attentivement les piles de linge } \\
\text { de l'Exposition de Blanc, imitant habilement } \\
\text { des montagnes de neige, ou bien une poupée } \\
\text { dont les dents et les yeux, à intervalles } \\
\text { réguliers, s'allumaient, s'éteignaient, } \\
\text { s'allumaient, s'éteignaient, s'allumaient, } \\
\text { s'éteignaient, toujours à intervalles } \\
\text { identiques, s'allumaient de nouveau et de } \\
\text { nouveau s'éteignaient. }\end{array}$ & $\begin{array}{l}\text { Egyfajta különös csend, reménytelen } \\
\text { elégedettség árad belölük. Figyelmesen } \\
\text { nézik a Fehér Kiállítás mosodai ruhahalmait } \\
\text { - hófödte csúcsok leleményes másolatait, } \\
\text { vagy egy babát - fogai és szemei rendszeres } \\
\text { időközönként felfénylenek, elcsitulnak, } \\
\text { felfénylenek, elcsitulnak, felfénylenek, } \\
\text { elcsitulnak, mindig azonos időmúlással } \\
\text { felfénylenek újból és újból elcsitulnak. }\end{array}$ \\
\hline
\end{tabular}

A babákkal való szembesülés elsősorban nem érintkezés, $\mathrm{s}$ a találkozás tapasztalatából nem is születik valódi megértés. Ugyanakkor a felfénylő és az újra csak kialvó szemek letaglózó érzete nem csak a terméketlenség kínját sugallják, hanem valamiféle balsejtelmet is előrevetítenek. Ha a valóság másolása elsődlegesen ellehetetleníti a befogadó és a mű valódi találkozását, a szereplő-baba ijesztő személytelensége, e viaszfigurának adott arc-maszk letaglózott megigézettségében is igazán távol tartja magától szemlélőjét. Az Usage de la parole első része, amelyben nőíró létére Csehovnak a halálos ágyán elmondott utolsó szavainak szómögöttes tartalmait fejti ki, szintén arra utal: az író nemétől függetlenül az írásban a tropizmuson van a hangsúly. De a nemeknek a szereplők esetében sincs minden esetben jelentősége ${ }^{315}$.

Gilles Deleuze fogalma, a rizóma asszociálódik Nathalie Sarraute tropizmusterminusával. „Rizóma. Bizonyos, hogy semmi köze a nyelvhez, éppen ellenkezőleg, a nyelv

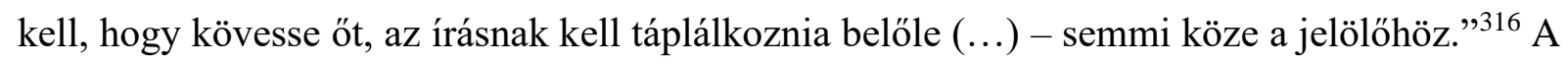
rizóma a fának, a gondolkodás metaforájának ellentéte. A mesebeli életfa összeköti a transzcendenst a földivel, a bibliai tudás fájának gyümölcse megismerteti velünk az erkölcsi jót és a rosszat. Amikor nemzeti identitást keresünk, mindenki a gyökereire hivatkozik. A hatalom mindig fajellegü. Szinte nincs olyan tudomány, amely ne fa-sémát követne (biológia, nyelvészet, informatika). A rizomatikus gondolkodásmód az, amikor a dolgok között gondolkodunk - vonalat húzunk, amely kitér a struktúra elöl, ezek a szökésvonalak, a leendések, jövő és múlt nélkül, emlékezet nélkül, s ellenállnak a bináris gépnek. A rizóma nem szubjektum, hanem kollektív megnyilatkozás-elrendeződés. ${ }^{317}$

\footnotetext{
${ }^{315}$ Besser, Gretchen Rous (1976), "Colloque avec Nathalie Sarraute" The French Review 22 avril 1976, , p. 288.

${ }^{316}$ Deleuze-Guattari (1980). Mille plateaux, p. 248. "Rhizome. A coup sûr elles n'ont rien à voir avec le langage, c'est au contraire le langage qui doit les suivre, c'est l'écriture qui doit s'en nourrir (...) elles n'ont rien à voir avec un signifiant."

${ }^{317}$ Deleuze-Parnet (2016). p. 26-28.
} 
A két író fogalomköréből származó terminusok a biológia, a botanika tárgyköréből valók, a rizóma éppúgy, mint a tropizmus. A rizóma növényi gyökérszerkezet, amely a főgyököt és mellékgyököket magában foglaló gyökértípustól eltérően horizontálisan terül el (pl. gyom). Nyílt rendszert hoz létre, akárcsak a tropizmus, amely nem egy adott szereplő története egy helyszínen az idő egy pontján, hanem a szómögöttesből szerveződő jelenidejü képáramlat. A rizóma sem szerveződik hierarchikusan, és mivel nem logikusan formálódik, bárhol megszakítható. Ez a köztes helyzet, állapot, kettőközöttiség, amely nyomán asszociálódhat a rizóma és a tropizmus. A tropizmus, akárcsak bármely rizomatikus elrendezettségű valóságelem dinamikus, leendésében, szökésvonalaiban, kiszámíthatatlanságában követhető, alakulása és nem megérkezése benne az, ami magára irányítja a figyelmünket. A tropizmus éppúgy ellenáll a bináris gépnek, mint a rizóma, mert célja nem az, hogy a külső valósággal szemben belső valóságot mutasson. Egyiket sem kívánja közölni, megmutatni, hanem egy harmadikat, a megnevezhetetlen érzettömböket sejteti.

Fontos még a tropizmusok világában az arctalanítás gesztusa, hiszen a stílus hagyományos felfogásával szemben, amely az íróra jellemző egyéni, a köznapitól eltérő, ám konstans módon csak rá jellemző nyelvhasználattal szemben Sarraute a stílust kiszakítja tautologikus, saussure-i, a nyelvi megformálást csak nyelviként értelmező látásmódjából. Pragmatikusan fogja fel, beszédhelyzetekben érvényesít, stilisztikai eszközökkel deverbalizálja, megtölti élettel, és a stílust élethelyzetek heterogenitásában tölti meg újra és újra a lüktető valósággal. Ahogyan Deleuze fogalmaz róla:

„Nathalie Sarraute fontos különbségre hívta fel a figyelmet (ES, p.52.), amikor formaszerveződéssel és a szereplők vagy karakterek fejlődésével azt az egészen más síkot helyezte szembe, melyet egy ismeretlen anyag részecskéi ölelnek körül, s ,ezek higanycseppek módjára egyfolytában arra törekednek az őket elválasztó burkon keresztül, hogy összekapcsolódjanak és közös masszában elegyüljenek": kollektív megnyilatkozás-elrendeződés, deterritorializált riturnália, a vágy konzisztenciasíkja, ahol is a tulajdonnév minden személyességét elveszítve jut legmagasabb individualitásához - észrevétlenleendés, Joséphine, az egér. ${ }^{318}$

\footnotetext{
${ }^{318}$ Deleuze-Parnet (2016). p. 104.
} 


\section{V.1. A tropizmus filozófiai értelemben}

Mint már említettük, az Új Regény nyelvszemléletének hátterében a reprezentációs irodalmi iskolákkal való szembenállás és az ideológiák ellehetetlenülése állt ${ }^{319}$. Az új regényírók némelyike aláírta a „121-ek kiáltványát”, amely az Algériába kivezényelt katonák számára követelte a hadkötelezettség visszautasításának jogát. Mégsem politikai vagy ideológiai szemléletük közösségében, hanem a mimetikus írói eljárások visszautasításában lehet megtalálni bennük a közös vonást. Ha emögött filozófiai kapcsolódást keresünk, akkor egyrészt a gyanakvás filozófiájára kell gondolnunk, másrészt a fenomenológiai kötődésre.

Az előbbire példa Nathalie Sarraute már említett esszéje, A gyanakvás kora, melynek filozófiai háttere az, hogy a világot megismerhetetlennek, sőt, gyakran elgondolhatatlannak, verbálisan megragadhatatlannak tételezhetjük, s benne az én maga is komoly ismeretelméleti problémákkal küzd, mind önmagára, mind a világra, mind a nyelvhasználatra, a kommunikációra vonatkoztatva nehezen talál fogódzókat ${ }^{320}$. Vajon ennek nem az az oka, hogy az irodalom csalódott ${ }^{321}$ ? Annyiszor igyekezett formálni a politikát és az végül is, és mégis mindig az érdekek mentén ${ }^{322}$ alakult. Filozófiailag az Új Regény által képviselt irodalom- és nyelvfelfogásnak, a társadalmi vetülettel szembeni gyanakvás kiváltotta radikális nyelvi hermetizmusnak ez áll a hátterében, s mint ilyen, védelemre szorul. Angyalosi Gergely Butort idézi: a költészet egy eltünt szakrális világ nosztalgiájából táplálkozik, költő az, aki tudatában van annak, hogy a nyelv és vele együtt valamennyi emberi dolog veszélyben van. Eltűnhet-e az elbeszélés? Megsokszorozódhat, konfliktusba kerülhet önmagával, de eltűnhet-e valóban? „A Nouveau Roman íróinak elbeszélés-ellenessége főleg ebből a veszélyérzetből kiindulva érthető meg. A nyelvhasználatról alkotott koncepciójuk nyomán indultak el ezek az írók, és úgy leltek rá egyfajta (a mai napig változásban lévő) világszemléletre"323.

„A Nathalie Sarraute-féle pszichologizáló módszert az kapcsolta az Új Regényhez, hogy egy lényeges ponton ugyanabban az irányban akart változtatni, mint a többiek. A narrátor mindentudó, „atyaúristeni” pozícióját megszüntetve egy „névtelen, mindenkiben azonos anyag" felfedezését tüzte ki célul. Az anonimitás, a konkrét személy feloldozása valamilyen formában mindegyik említett írónál közös; a többiek azonban inkább a szövegszerüség egyes aspektusaira és a közvetlen érzékelés-aktusok leírására fektettek hangsúlyt. Így a „lélektani” Nouveau Romanra nemigen tudnánk újkeletü példát hozni” ${ }^{24}$.

\footnotetext{
${ }^{319}$ Viart (1993). p. 112.

${ }^{320}$ Viart (1993) p. 121.

${ }^{321}$ Angyalosi (1996). p. 97.

322 cui prodest? Senecának tulajdonított.

${ }^{323}$ Angyalosi (1996). p. 110.

${ }^{324} \mathrm{Uo}$.
} 
A sarraute-i újfajta nyelvi attitüd csak részben tér el a régebbi nyelvértelmezésektől. A kimondott szavak azelőtt is megértésre szorultak. Az olvasó mindig is értelmezte a müvet. A sarraute-i nyelvi forma hátterében azonban ott áll érzeteink-érzéseink kimondhatatlanságánakkifejezhetetlenségének tudata, azaz a jelentésbe, a nyelv használatelméletébe vetett bizalom megrendülése, amiből már következik a konnotáció elsődlegessége. Mindez a stílus szintjén az újra és újramondásban ölt testet, illetve a nyelv és az érzetek egységének problémáját veti fel: olyant kíván kifejezni szavakkal, amiket csak a bőrén érez. Neumer Katalin átélt beszédnek nevezi, amikor a nyelvi kifejezés meg kívánja mutatni a szó előtti valóságot magát. Szerinte ez sem nem egyenes beszéd, sem nem függő beszéd: a szereplő és a szerző nézőpontja összeolvad. Maga a beszélő sincs tisztában a szavakkal, újabb és újabb megfogalmazásokkal, megközelítésekkel kísérletezik, próbálja kifejezni magát. Gondolatai kicsúsznak a szavak hálójából. Az elmondhatóság, az értelmezés, a kimondás magának a münek a problémájává válik. ${ }^{325}$

Angyalosi Gergely szerint Simone de Beauvoir Új Regény-kritikájának lényege, hogy szerinte az irodalom nemcsak a Van, hanem a Legyen is, az irodalom nem a mindennapokhoz tartozik, hanem ünnep (Sartre). Nem vesztheti el a nevelés, az átalakítás, a fejlesztés lehetőségét, vágyát. Angyalosi rámutat, hogy korunk legnagyobb filozófiai kérdésfeltevése valóban, hogy a „Legyent” a „Vanból” - isteni transzcendencia híján - nem tudjuk levezetni. Miféle alany hordozhatná úgy ezt az egységet, hogy nem lesz hamis, mesterségesen előállított? ${ }^{326}$ Sarraute elképzelése szerint a tropizmus valósága nem a „mindenki által erőfeszítés nélkül érzékelt felszín valósága, amelyet jobb híján mindnyájan 'használunk""327. „Előfordul néha, hogy elérünk valami még ismeretlent, amit mintha mi látnánk meg először. (...) Azon van az ember, hogy felszínre hozza ezt a valóságdarabot, ami csak az övé"328. Ennek a másik valóságnak a létezése a tropizmus sarraute-i filozófiája, és ennek a másik valóságnak a haptikus, a stílus leendésében megvalósított tropizmikus szerveződése Sarraute alkotásmódja.

A két valóság összeegyeztethetőségének lehetőségére is megvan tehát Sarraute csak rá jellemző válasza. Az egyik valóságtól teljesen elfordul: ez a geometrikus elme, a logika, sőt, a retorika mechanizmusaira épülő hiteltelen, klisékkel zsúfolt, hazugságokkal tüzdelt valóság,

\footnotetext{
325 Neumer Katalin (1995). Tévelygések a nyelv labirintusában, Budapest, MTA Filozófiai Intézete, Doxa Könyvek, p. 33-34.

${ }^{326}$ Angyalosi (1996). p. 99-100.

${ }^{327}$ Sarraute (1956). p. 138. "Ce que voient les oiseaux"

${ }^{328}$ U.o. „Il arrive parfois à atteindre quelque chose d'encore inconnu qu'il lui semble être le premier à voir. (...) Il cherche à mettre au jour cette parcelle de réalité qui est la sienne.”
} 
amely szembenáll a hitelesen építkező autentikus valósággal. ${ }^{329}$. „A szereplő akkor fordul a hiteltelen nyelvi fordulatokhoz, amikor rejtegetni valója van és az író feladata, hogy rávilágítson a hazugságra annak felnagyításával, ironikus hangsúlyozásával".330 Dosztojevszkij „barlangászati kutatásnak”331 nevezi ezt a fajta írói attitűdöt. Látványos a különbségtétel eközött az új szómögöttes, mikropszichológiai részecskéket megmozgató, felszínre hozó szövegvilág és a klasszikus értelemben való lélektani elemzést-ábrázolást lehetővé tevő, megnevezhető érzelmekből, erkölcsökből összeálló jellemek között.

A gyanakvás mellett a másik felvetődő filozófiai megközelítés a fenomenológiai nézőpont, melyre jó példa Alain Robbe-Grillet írásmódja. Határozottan elutasítja a metafora minden lehetséges változatát és tárgyias stílus ${ }^{332}$ megteremtését célozza, hogy ezzel is hangsúlyozza a dolgok egyszerü, minden ideológiától mentes jelenlétét ${ }^{333}$. Az Új Regény szerzői azért fordultak el a mimézistől, mert az ábrázolhatóság hiányosságai mögött olyan filozófiai problémák sejlettek fel előttük, mint a valóság leírhatóságának, rögzíthetőségének nehézsége az irodalmi müben.

„Míg a tényekre alapuló elbeszélésnek mindig van alapja, forrása valamely rajta kívül eső valóság evidenciája, a regénynek meg kell elégednie azzal, hogy azt idézi fel, amit elbeszél. Ezért van az, hogy a regény fenomenológiai vizsgálatok elsődleges tárgya lehet: megmutatja, hogy a valóság milyen módon jelenik vagy jelenhet meg számunkra." 334

Ahogyan Michel Butor, úgy Ludovic Janvier ${ }^{335}$ Beckett-szakértő 1954-ben, Une Parole exigeante / [Igényes beszéd] címü elméleti munkájában szintén fenomenológiai alapokra helyezi az új szépirodalmi alkotások módszerét: az itt és most megragadásának kísérlete zajlik a szubjektív tudat által. Ismétlődések, fragmentáltság, egyidejűség, analógiák, az időbeli linearitás, az oksági viszonyok ellehetetlenítése, tér,- és időviszonyok egyértelműségének feloldása: nyelvileg ebben áll a tropizmusok filozófiájának megvalósítása. ${ }^{336}$ A tropizmusok világában metonimikusan fel-felbukkannak olyan klasszikus irodalmi témák, mint az önbecsülés, a dominanciaharc, az alárendelődés, és további, lélektani terminológiával

\footnotetext{
329 Tison-Braun (1971). p. 12.

${ }^{330}$ U.o. p. 13. „Le personnage recourt à ces artifices quand il veut cacher quelque chose, et l'auteur pour signaler le mensonge par un grossissement, un systématisation ironiques."

${ }^{331}$ U.o. p. 13. „explorations spéléologiques”

${ }^{332}$ Viart (1993). p. 115. „style objectal”

${ }^{333}$ Uo. ,être-là”

${ }^{334}$ Butor, Michel (1992). Essais sur le roman, Gallimard, p. 9. "Alors que le récit véridique a toujours l'appui, la ressource d'une évidence extérieure, le roman doit suffire à susciter ce dont il nous entretient. C'est pourquoi il est le domaine phénoménologique par excellence, le lieu par excellence où étudier de quelle façon la réalité nous apparaît ou peut nous apparaître."

${ }_{335}$ Viart (1993). p. 117. Ludovic Janvier (1964.) Une parole exigeante, Le nouveau roman, Éditions de Minuit ${ }^{336}$ Uo. p. 112.
} 
megragadható problémafelvetések, ugyanakkor a szerző valódi célja a titkok kitapogatása. „A hazugságot ábrázolja, de az igazságot keresi." ${ }^{337}$ Nathalie Sarraute életmüvének filozófiai háttereként tehát elsődleges fontosságú az egyetemesség hite és igénye, azaz hogy a szavak nélkül kifejezhető valóság szintjén, azokban a régiókban, amelyekben az anonim érzet burjánzik, mindnyájan, kivétel nélkül egyek vagyunk és létezik valamiféle mellérendelésekkel érzékeltethető igazság. Nem abban különbözünk, hogy vannak-e szinte észrevétlen tropizmikus mozgásaink, mert abban egyek vagyunk. Hanem abban, hogy tudomásul vesszüke, akarjuk-e magyarázni vagy elfogadjuk-e, hogy ezek megmagyarázhatatlanok.

„Nem létezem” - mondja az írónő egy interjúban. „Olyan érzésem van, hogy ahol én vagyok, ott mintha egy üres hely lenne... azért vagyok mindig szabad, mert nem létezem." ${ }^{338}$ Máshol így fogalmaz: „Csak az vagyok, amit leírtam. Semmi olyan, amit nem ismerek, amit kivetítenek rám, amit szándékom ellenére rámhárítanak, ahogyan az megállíthatatlanul folyik ott, kint, a másik életemben..." ${ }^{339} \mathrm{Az}$, hogy az én radikálisan nem tudatosul az írónő saját személyére vonatkozóan sem, kivetül a teljes életmüre: a szereplő-alak soha nem nyer stabil, körülhatárolható kontúrokat. Az esetleges életrajzi mozzanatok, a kettősnyelvűség is akár, feloldódik a szövegben, amely az egyébként virtualitásokban, több nyelvben, kultúrában és szerepben létező én egyetlen integratív lételeme. A szerző megszűnik és megszületik a maga egyediségében a szépirodalmi alkotó.

A Sarraute-szövegek énfogalma rendkívül egyénített, egyetlen más író életművében sem jelenik meg hasonló: a szereplő-foglalatok, lehetnek bőbeszédűek vagy lehetnek csendben, üresek, nincs kapcsolat személyiség és gondolkodásmód között. A szómögöttes beszél helyettük, magától beszél ${ }^{340}$, rajtuk átszürve beszél, mintha az „Az” önállóan gondolkozna. Feltehetjük a kérdést, hogy létezik-e anonim gondolat vagy általános gondolat, amelynek alanya az ember mint olyan ${ }^{341}$. Az énfelfogások, onnan, hogy az én isteni eredetü, a descartes-i ,gondolkodom, tehát vagyok”-on keresztül, eljutottak a becketti abszurd senkit és

\footnotetext{
337 Tison-Braun (1970). p. 30-31. „C'est la vérité qu'elle poursuit à travers le mensonge.”

338 Benmussa (1999). p. 78. "Je n'existe pas" "(...) J'ai l'impression que là où je suis, il y a comme une place vide... je suis toujours très libre parce que je n'existe pas"

${ }^{339}$ Sarraute (1996) p. 1081 "Je ne suis rien d'autre que ce que j'ai écrit. Rien que je ne connaisse pas, qu'on projette sur moi, qu'on jette en moi à mon insu comme on le fait constamment là-bas, au-dehors, dans mon autre vie..."

${ }^{340}$ U.o. p. 43. „Ça parle en eux”. Érdekes a magyarban nehezen visszaadható személytelen mutató névmás használata. „Az”. Ráadásul a ça a német ES, vagy ID - a magyar ösvalami, ösztönén.

${ }^{341}$ U.o. „Existe-t-il donc une pensée anonyme, une pensée sans sujet ? On reconnait ici le ON de Heidegger, l'illusoire „transcendance de l'Ego” signalée par Sartre, les réflexions de Lacan et de Foucault sur l'autonomie du langage.” „Létezik-e olyan, hogy anonim gondolat, alany nélküli gondolat? Itt felismerni véljük Heidegger általános alanyát, a Sartre által illuzorikusan Én-transzcendeciaként megragadott én-fogalmat, a Lacan és Foucault gondolatmenetében felvázolt autonóm nyelvfelfogást."
} 
mindenkit jelentő alanyáig. Sarraute szómögöttes tartalmaiból kibontakozó köd-én fájdalmas ür, de inkább a mindenki, mint a senki. Senki semmiképpen sem, hiszen mindig kapcsolatban van, és mindig az eleven élet lüktet benne. Ezért nincs semmi abszurd vagy irracionális a Sarraute-szöveg én-jében. Nem valamiféle valóságon túli irracionális, misztikus valóságról kívánja lerántani a leplet, hanem hiszi, hogy ez az én ez nem más, mint a valóságon túli valóság, és nincs verbálisan megmutatható arca.

Azt a névtelen és minden emberi létezőben közös anyagot, amelynek dinamizmusát a szavak fogalmi jelentése nem fejezheti ki, ezért helyezi mindig Sarraute egymás mellé és újra egymás mellé a szavakat, s ennek a felsorolásnak, metonímiák hálójának dinamizmusát nevezi a biológiából vett terminus segítségével tropizmusnak. Ezért van az, hogy arctalanít, elutasítja a klasszikus karakterfelfogást és újfajta figuráció jellemzi írásművészetét, amelynek jellemzője, hogy „látszólagos identitás nélkül építi fel őket, mégis újra és újra identitásuk mélyrétegeibe merül." 342

A Tropizmusok V. szövegében a tropizmus-jelenség által felvetett két legjelentősebb filozófiai probléma, a valóság keltette bizalmatlanság által megidézett „másik valóság”, valamint a fenomenológiai nézőpont értelmezhető.

\begin{tabular}{|c|c|}
\hline $\mathrm{V}$. & V. \\
\hline $\begin{array}{l}\text { Par les journées de juillet très chaudes, le } \\
\text { mur d'en face jetait sur la petite cour } \\
\text { humide une lumière éclatante et dure. }\end{array}$ & $\begin{array}{l}\text { A júliusi hőség napjaiban a szemben málló } \\
\text { tüzfalról élénk gyémántfény zuhogott az } \\
\text { aprócska nedves udvarra. }\end{array}$ \\
\hline $\begin{array}{l}\text { Il y avait un grand vide sous cette chaleur, } \\
\text { un silence, tout semblait en suspens ; on } \\
\text { entendait seulement, agressif, strident, le } \\
\text { grincement d'une chaise traînée sur le } \\
\text { carreau, le claquement d'une porte. C'était } \\
\text { dans cette chaleur, dans ce silence - un froid } \\
\text { soudain, un déchirement. } \\
\text { Et elle restait sans bouger sur le bord de son } \\
\text { lit, occupant le plus petit espace possible, } \\
\text { tendue, comme attendant que quelque chose } \\
\text { éclate, s'abatte sur elle dans ce silence } \\
\text { menaçant. }\end{array}$ & $\begin{array}{l}\text { E höség alatt ür volt és csend, mintha } \\
\text { felfüggesztették volna az elevenséget; } \\
\text { egyedüli zajként a keramitkövek zúgolódása } \\
\text { volt észlelhető, a rajtuk húzódó karosszék } \\
\text { agresszív, fülsértő csikorgása, majd egy } \\
\text { távoli ajtó becsapódása. És ebben az } \\
\text { elviselhetetlen melegben, e csönd- } \\
\text { történésben - mint hideg áramlás vált ki a } \\
\text { leszakadó zaj. } \\
\text { És a lány mozdulatlanul maradt az ágya } \\
\text { szélén, a lehető legkisebb helyet foglalva el, } \\
\text { feszülten alélt, mintha azt várná, hogy } \\
\text { valami robbanni készül, lesújt rá e fenyegető } \\
\text { csendözönben. } \\
\text { Néha a napsütésbe dermedt halottmerev }\end{array}$ \\
\hline
\end{tabular}

\footnotetext{
${ }^{342}$ Bonetti p. 46. figuration renouvelée - „on les pose sans identité apparente, mais on ne cesse d'en fouiller l'identité profonde"
} 
solitude, d'abandon dans un univers hostile où quelque chose d'angoissant se prépare.

Étendu dans l'herbe sous le soleil torride, on reste sans bouger, on épie, on attend.

Elle entendait dans le silence, pénétrant jusqu'à elle le long des vieux papiers à raies bleues du couloir, le long des peintures sales, le petit bruit que faisait la clef dans la serrure de la porte d'entrée. Elle entendait se fermer la porte du bureau.

Elle restait là, toujours recroquevillée, attendant, sans rien faire. La moindre action, comme d'aller dans la salle de bains se laver les mains, faire couler l'eau du robinet, paraissait une provocation, un saut brusque dans le vide, un acte plein d'audace. Ce bruit soudain de l'eau dans ce silence suspendu, ce serait comme un signal, comme un appel vers eux, ce serait comme un contact horrible, comme de toucher avec la pointe d'une baguette une méduse et puis d'attendre avec dégoût qu'elle tressaille tout à coup, se soulève et se replie.

Elle les sentait ainsi, étalés, immobiles derrière les murs, et prêts à tressaillir, à remuer.

Elle ne bougeait pas. Et autour d'elle toute la maison, la rue semblaient l'encourager, semblaient considérer cette immobilité comme naturelle.

Il paraissait certain, quand on ouvrait la porte et qu'on voyait l'escalier, plein d'un calme implacable, impersonnel et sans couleur, un escalier qui ne semblait pas avoir gardé la moindre trace des gens qui l'avaient parcouru, pas le moindre souvenir de leur passage, quand on se mettait derrière la fenêtre de la salle à manger et qu'on regardait les façades des maisons, les boutiques, les vieilles femmes et les petits enfants qui marchaient dans la rue, il paraissait certain qu'il fallait le plus longtemps possible - attendre, demeurer ainsi immobile, ne rien faire, ne pas bouger, que la suprême compréhension, que la réteken a tücskök éles ciripelése visszhangozza így a magány jéghűvös érzetét, a jövőt feszítő szorongás, karnyújtásnyira a gyülölettől, így lepi meg az elhagyottat.

Elnyújtózás a füben, a perzselő nap alatt mozdulatlan megmaradás, figyelmes várakozás.

A bejárati ajtó zárjában fordult a kulcs, zaja neszez, mintha a folyosók hosszán elnyúló megfakult festés és a kék csíkos öreg tapéta hozta volna, átszivárog a lány csendjébe. Hallotta, ahogyan csapódik a dolgozószoba ajtaja.

Ottmaradt, összekucorodva, várakozón, minden mozdulat nélkül. Elmenni a fürdőszobába kezet mosni vagy folyatni a csapvizet bántónak tünt, a legkisebb cselekedet ötlete is úgy merült fel, mint ugrás a mélybe, vakmerő tett. A víz zubogása a felkarolt csöndben olyannak tetszett volna, mint egy feléjük intő hívogatás, érintkezésre szólító jeladás, viszolyogtató, akárha egy pálca végével valamely medúzát érintenénk, és vegyes undorral várnánk, amikor az összerándul, mozdulni kezd és kinyílik.

A lány csak érezte őket, mint a moccanatlanságot meg az ugrásra kész vacogást a falakban.

Nem rezzent. És körülötte a ház, az utca úgy tünt, bátorítja erre, természetesnek tüntetve fel ezt a halk mozdulatlanságot.

Amint az ember kinyitja az ajtót és meglátja a lépcsőt, szíve telve szenvtelen, személytelen és színtelen nyugalommal, a nyurga lépcsőt, amely a rajta áthaladó emberek lépteiből, itt jártuk legkisebb emlékéből szemlátomást mit sem őriz meg, amint az ebédlő ablaka mögé kucorodunk fürkészni a házak homlokzatát, az üzletsorokat, az idősödő nőket, az aprónépséget, mely az utcán sokasodni látszik, akkor bizonyosnak az tünik, hogy a lehető legtöbb időre van szükség - a 
véritable intelligence, c'était cela, ne rien entreprendre, remuer le moins possible, ne rien faire.

Tout au plus pouvait-on, en prenant soin de n'éveiller personne, descendre sans le regarder l'escalier sombre et mort, et avancer modestement le long des trottoirs, le long des murs, juste pour respirer un peu, pour se donner un peu de mouvement, sans savoir où l'on va, sans désirer aller nulle part, et puis revenir chez soi, s'asseoir au bord du lit et de nouveau attendre, replié, immobile. várakozásra, a mozdulatlan maradásra, a semmit sem tevésre ; hogy a legvégső megértés, az igaz értelem evvel lepjen meg - semmibe nem belefogni, a lehetö legkevesebbet mozogni, mit se tenni.

Legfeljebb arra van mód, hogy vigyázva, senkit nem felébresztve, óvatos észrevétlen, oda se pillantva leereszkedjük a homályos lépcsőn és majd visszafogott haladással a járdán, a falak mentén, csak hogy némi levegöhöz jussunk, egy csepp mozgás érjen, jóleső zsibbadás az elgémberedett végtagjainkban, nem tudva, hová, de nem is vágyva arra, hogy bárhová is tartsunk, visszajöjjünk, ide haza, leülvén az ágy szélére és újból várjunk, befelé hallgatózva, némán.

A szöveg szereplöjére az elle - ő, a lány névmáson kívül semmi nem utal, és csak a harmadik bekezdésben jelenik meg. Az első két bekezdés leginkább környezetleírásra hasonlíthatna, de célja csak látszólag ez, valójában a két valóság, az érzékekkel felfogható, látható, hallható valóság és a másik valóság éles szembeállítása.

\begin{tabular}{|c|c|}
\hline érzékekkel felfogható valóság elemei & „másik valóság” létezése \\
\hline $\begin{array}{l}\text { júliusi hőség, szemben málló tüzfal, } \\
\text { aprócska nedves udvar, zaj, keramitkövek } \\
\text { zúgolódása, a karosszék agresszív, fülsértő } \\
\text { csikorgása, egy távoli ajtó becsapódása }\end{array}$ & $\begin{array}{l}\text { élénk gyémántfény zuhogott, ür volt és } \\
\text { csend, mintha felfüggesztették volna az } \\
\text { elevenséget, csönd-történés, csendözönben }\end{array}$ \\
\hline
\end{tabular}

Az érzékekkel felfogható valóság a jelenségek szintjén látható, hallható, kitapintható, érzékelhető: az erős érzéki hatások legtöbbje a hallásunkra (zajok, ajtóbecsapódás, karosszék húzása), valamint a tapintásunkra (nedvesség, hőség) apellál, de mindezt nem köti valós beszédhelyzethez, csupán arra szolgál, hogy éles ellentétet képezzen a mögötte meghúzódó érzékekkel fel nem fogható másik valósággal. A visszatükröződő fény a szöveg erős költői felütésében jól példázza a valóság érzékelhetőségében átélt gyanakvás filozófiáját ${ }^{343}$, a következő három bekezdésben pedig háromszor, már-már retorikus átéltséggel ismétli a csend

\footnotetext{
${ }^{343}$ mintha tükör által homályosan látnánk, Korinthusbeliekhez írt I. levél 13. rész 12. vers
} 
szót különféle kontextusokban, de ugyanazzal a céllal, hogy megidézze az érzékekkel fel nem fogható realitásfelületet.

A szövegépítkezés, bár ezután két rövid bekezdésben szerepelteti az elle-t, valójában ezt az arctalanított létfelületet hivatott kitapinthatóvá tenni úgy, hogy a lányra vonatkoztatja az addigi bekezdésekben ismételt „csend” szó helyett a kétszer elforduló „mozdulatlan” kifejezést, melynek segítségével a másik valóság, a csendvilág mintegy átszivárog a lány által megjelenített emberi realitásba. Ám ennek az tropizmikus átitatottságnak a drámája is megjelenik egyúttal: a leleplezés, a való világ fixa ideái, azok eseményszerủ kegyetlensége bár csak utalásokból értelmezhetően - de megkérdőjelezhetetlenül jelenvalóak: „feszülten alélt”, „,valami robbanni készül”, „lesújt”, „fenyegető”. Sarraute költői átéltségű, ugyanakkor precízen megszerkesztett szövegét mintegy szétfeszíti a tropizmus csendvalósága és a tárgyak jelenségvilága közötti már-már gyilkos ambivalencia. Ahogyan utal is arra egyik esszéjében:

„A modern ember, az ellenséges erők közt hányódó lélek nélküli test, végül is nem más, mint aminek kívülröl látszik. A magárahagyatottságában az arcán tükrözödö sivár levertség és mozdulatlanság, amelyeket a felületes szemlélő figyelhet meg, nem takarnak különösebb belső hullámzást. Ez a 'csendhez hasonló zaj', amelyet a pszichológia hívei érzékelni véltek a lélekben, csak a csend volt."”344

Ez a fenyegető ür nem a szövegvilág tőlünk függetleníthető beszédhelyzetében és eseménysorában érhető tetten, kényelmes katarzist okozva ezzel. Hanem az írónő, látszólag költőien megformált gyönyörködtető sorokkal, de bevonja az olvasót ennek a lélek nélküli csendnek a valóságába, olyannyira, hogy a szöveg első fele két „on” általános alanyú állítmánnyal végződik: „figyelünk”, „várunk”. A fordításban az általánosító hangnemet és célzatot, a személytelenséget főnevek halmozásával értem el: „elnyújtózás”, „mozdulatlan megmaradás”, „figyelmes várakozás”.

Az V. szövegegység második részének eleje látszólag epikus beszédhelyzetet teremt a nőnemű szereplő-alak köré: „bejárati ajtó”, „dolgozószoba ajtaja”. Ugyanakkor a környezeti tényezőkre vonatkozó igék szerepeltetésével mintha metonimikusan valamiféle eseménysort építene fel: „zárjában fordult a kulcs”, „zaja neszez”, „csapódik”. Megkapó, ahogyan még itt sem mond le a tropizmikus szinesztéziákkal felépített utalásrendszeréről: „mintha a folyosók hosszán elnyúló megfakult festés és a kék csíkos öreg tapéta hozta volna, átszivárog a lány csendjébe" - látásra, hallásra és tapintásra asszociáltat egy képen belül. A szöveg közepén

\footnotetext{
${ }^{344}$ Sarraute (1956). p. 17. "De Dostoievski à Kafka" "L’homme moderne, corps sans âme ballotté par des forces hostiles, n'était rien d'autre en définitive que ce qu'il apparaissait au-dehors. La torpeur inexpressive, l'immobilité qu'un regard superficiel pouvait observer sur son visage, quand il s'abandonnait à lui-même, ne cachait pas de mouvements intérieurs. Ce 'tumulte au silence pareil', que les amateurs du psychologique avaient cru percevoir dans son âme, n'était après tout, que silence."
} 
elhelyezkedő „ottmaradt, összekucorodva” kezdetü kulcsbekezdés mintegy a minidráma megoldásának is tekinthető. Bár a kegyetlen realitás hívó szava itt már leplezetlen: „intő hívogatás, érintkezésre szólító jeladás”, a lány teste mintegy önkéntelen döntést hoz arról, hogy nem lép ki a tropizmus csendvalóságából: „A lány csak érezte őket, mint a moccanatlanságot meg az ugrásra kész vacogást a falakban. Nem rezzent.” Az író a szerepeltetett elle alanyról ismét az on-ra vált, hogy ezzel az általánosító gesztussal a szövegzárlatban ismét egybefolyassa a szöveg és az olvasó valóságát.

„A tropizmikus valóságban mindnyájan egyek vagyunk"345. A fenti, V. topizmus azért különösen érdekes, sőt, még el is tér a kötet többi szövegegységtöl, mert a benne található minidrámának nincs a valóság szintjén verbalizálódó sztereotípia-vetülete. Hiányzik belőle a többi szöveg nagy részében ironikus látószögből megidézett konzum klisésor, melyet Raffy „nyelvi bűnnek”346 nevez. Az írónő itt pusztán a valóságos jelenségvilágából vett pointillista, egymás mellé helyezett fenoménsorokkal metonimikusan érzékelteti a kegyetlen realitás világát, de a többi szövegtől eltérően egyetlen képviselőjét sem szólaltatja meg, miközben a tropizmus árnyvilágából felmerülő alakkal

„egymásra találunk, tökéletesen azonosulunk, együttérzők vagyunk közös sorsunkkal szembesülve... körülöttünk, bennünk szédítő mélységek [...] köztünk is szakadék nyílik... elszakadunk egymástól, megtört csigaházunkból kivetetten, megváltan földi kérgünktől... [...] De mintha más szavakat találnék [...]... újakat, amik még összekötnek, egy húsból-vérbőll lett testünket egybeolvasztják..."347

\section{V.2. A tropizmusok hátterében megbújó szereplőfogalom}

A tropizmus tehát egyfajta „müködés”, a lelki élet szintjén lezajló aktivitás, amely a másokkal való együttlét során mutatkozik meg. Az írónő epikusan ragadja meg: testi válaszreakciókat ír le, lelki rezdüléseket, metaforákat, hasonlatokat alkalmaz, szómögöttes tartalmakat közvetít. Kifejeződhet a beszéd segítségével, ebben az esetben verbális tropizmusról beszélhetünk, de megnyilatkozhat gesztusok, cselekedetek, mozdulatok segítségével is, ekkor nem-verbális tropizmusról van szó. Feltételezhetjük, hogy Nathalie Sarraute azért vezeti be ezt a terminust az esszéiben, mert jól kifejezi az írónő elsődleges

\footnotetext{
345 Raffy, Sabine (2002). "Une lecture paranoïaque de l'œuvre de Nathalie Sarraute" Critique janvier-février 2002. 656-657. sz. p. 15.,,Au niveau des tropismes nous sommes tous les mêmes."

346 U.o. p. 17. crime linguistique

${ }^{347}$ Sarraute, Nathalie (1983). L'usage de la parole, p. 92. „Ils sont surs de se retrouver, parfaitement identiques, entièrement solidaires devant un sort commun... autour de nous, en nous les gouffres vertigineux [...] et entre nous une crevasse s'ouvre... nous sommes arrachés l'un à l'autre, projetés hors de nos coquilles brisées, hors de nos enveloppes charnelles... [...] Mais voilà que je trouve... [...] d'autres mots [...]... ils vont encore nous rapprocher, faire adhérer davantage l'un à l'autre nos corps faits d'une même chair..."
} 
elbeszélői célkitüzését: nem az a fontos, hogy mi történik, hanem az, hogy az olvasás során mit élünk meg. A szereplők nem cselekvéssorok aktánsai, cselekvői, ennél fontosabb az, hogy pontosan hogyan tudja átadni a szöveg ethosza, stílusa azt, hogy milyen a testi-lelki valóságuk.

A tropizmusok a lélektani ábrázolás és elemzés határpontján mozgó szövegek. Sarraute állítása szerint minden külső hatást kizárva, belső világából merítve alkotta meg az első szövegeket, hatásuk azonban érvényesül a strukturalizmus és a nyelvészeti szempontú irodalomértelmezés kontextusában. Az olvasó már nem tud azonosulni a szereplővel, a stílust a szavak kalandjai, kontextualizálása, a szófordulatok adják, ezek helyettesítik a cselekmény fordulatait és a szereplők sorsát.

Nathalie Sarraute Roman et réalité [Regény és valóság] címü előadásában ${ }^{348}$ úgy oldja meg az irodalmi mü és a valóság a XX. században problematikussá váló kapcsolatát, hogy kétféle valóságról beszél.

„A valóság, amelyet mindenki lát maga körül, amelyet mindenki érzékelni tudna, ha ott állna előtte, az az ismert valóság. (...) Ez a (regényíró) számára csak látszat, optikai csalódás. Számára a valóság az ismeretlen, a láthatatlan. Úgy tünik, számára ez az elsődleges, az egyetlen, amit látni akar; és nem hagyja, hogy a kifejezés síkjára emeljék az ismert, már felhasznált formák felhasználásával." ${ }^{349}$

Száműzi poétikájából a szereplőt és a cselekményt, mert szerinte valamennyi hagyományos narratív eljárás csupán eltéríti az alkotó és az olvasó figyelmét is a felfedni kívánt ismeretlen valóságról. Hiába törekszik az író arra, hogy a szereplőt akár belülről, akár önellentmondásosságában, akár bonyolult lelki valóságában, akár legpontosabb pszichológiai komplexitásában ábrázolja, ez nem fog sikerülni, és ugyanez vonatkozik a külső, társadalmi valóságra is ${ }^{350}$. Az „élő valóság” ${ }^{351}$ fogalmának bevezetésével járja körül Sarraute, mit ért pontosan azon az új tárgyon, amely valamennyi müvének alapja.

\begin{abstract}
„Akkor mondják, hogy s szereplők mintha élnének, amikor cselekednek, gondolkodnak, beszélnek, annak megfelelöen, ahogy mi látjuk vagy hisszük, hogy cselekedni, gondolkodni, beszélni látjuk a körülöttünk lévő, könnyen felismerhető emberi típusokat, mert egy bizonyos irodalmi ízlés ezt tanította számunkra. (...) Ezeknek a szereplőknek olyan nagy érzelmeket tulajdonítunk vagy olyanokat fedezünk fel bennük, amelyek könnyedén körülhatárolhatóak, például féltékenység, szerelem, nagylelkűség, zsugoriság stb... ezeket lehet a jellemvonásaiknak tekinteni. ${ }^{352}$,
\end{abstract}

\footnotetext{
${ }^{348}$ Sarraute (1996). "Roman et réalité" in Euvres complètes, 1996. p. 1643.

${ }^{349}$ U.o. 1644. „Il y a la réalité que tout le monde voit autour de soi, que chacun pourrait percevoir s'il se trouvait en face d'elle, une réalité connue. (....) Elle n'est pour lui (le romancier) qu'une apparence, qu'un trompe-l'oeil. La réalité pour le romancier, c'est l'inconnu, l'invisible. C'est ce qu'il lui semble être le premier, le seul á voir ; ce qui ne se laisse pas exprimer par les formes connues et déjà utilisées."

${ }^{350}$ U.o. 1653.

${ }^{351}$ U.o. 1654.

${ }^{352}$ U.o. 1654. On dit que les personnages sont vivants parce qu'ils agissent, pensent, parlent conformément á la façon dont nous voyons ou croyons voir agir, penser, parler les types humains facilement reconnaissables dont nous nous voyons entourés, que nous a appris á voir une certaine littérature. (...) Et aussi parce qu'on leur prête
} 
Ezzel a szereplők cselekedetein és jellemén átszürt klasszikus valóságábrázolással szemben alkotja Sarraute az általa tropizmusnak ${ }^{353}$ nevezett sajátos szövegvalóságot, amelynek célja az ismeretlen valóság formailag mégis pontos és jellegzetes felmutatása. Az elnevezés onnan való, hogy a szerző által ábrázolni kívánt második valóság, a belső mozdulatok, lelki mozzanatok, a láthatatlan világban, valóságban lezajló cselekvésmorzsák hasonlítanak a növényi mozgásokra, arra, ahogyan az élő organizmus a fény felé törekszik ${ }^{354}$. Az írónő okfejtése azért érdekes és egyedi például az énelbeszélést megvalósító Joyce vagy Woolf írásművészetéhez vagy akár a lelki valóságot tudományosan feltáró pszichológiai vizsgálatokhoz képest, mert szerinte ezeket az ösztönös testi-lelki mozzanatokat egyaránt magukba foglaló emberi mozgássorokat nehéz megragadni és kifejezni, hol felbukkannak a tudatunk felett, hol megint elmerülnek megnevezhető érzelmeink, kimondható szavaink, elmesélhető tetteink alatt, mögött.

A tropizmus valósága nem valamiféle elvont élettér, hanem a kreatív energia nagyon is konkrét megnyilvánulása, az ismeretlen valóság ,érintetlen és új mozzanatainak felszínre hozatala, csoportosítása, kapcsolódási pontjaik megragadása, sürítése, tömörítése, tehát maga az alkotás, a mü. ${ }^{355 "}$ A változás az eddigi nézőponthoz képest csupán annyi, hogy nem valamiféle konkrét valóságot vagy a valóságnak valamely akár tudományosan, akár müvészileg megismerhető szeletét, például a lelki valóságot, igyekszik megragadni, hanem folyamatokat. „Valamennyi könyvem lényegét a születőben lévő, egyelőre megnevezhetetlen, a tudat szintjét még el nem érő mozdulatsorok alkotják, amelyeket tudatosításuk dermeszt közhelyekké. Folyamatos változásban, szüntelen „leendésben” vannak. ${ }^{356}$

A dadogásból kitermelődő szereplő-foglalatok rossz kis lárvák, ám a szómögöttes beszédfolyamból kiviláglik, hogy az emberi vonás vagy elhalt, bár valaha bennük volt, vagy nem tud kibomlani ${ }^{357}$. A hétköznapiságból felépülő tropizmusok minidrámáinak alapja az énte viszonynak az problematikus felfogása, hogy a kitüskézett, megüresített, csendbe burkolózó

ou découvre en eux de grands sentiments facilement discernables, tels que la jalousie, l'amour, la générosité, l'avarice etc., qu'on peut définir leurs traits de caractère."

${ }^{353}$ U.o. 1651.

${ }^{354}$ U.o. 1651. „Quand j'ai pensé á les réunir sous un même titre, je les ai appelées „Tropismes”, parce que ces mouvement intérieurs, ces actions invisibles que je montrais ressemblaient aux mouvements des plantes qui se tournent vers la lumière ou s'en détournent."

355 Sarraute (1996). "La littérature, aujourd'hui", in Euvres complètes „(...) fait jaillir ces éléments intacts et neufs, les groupe, leur donne une cohésion, les construit en un modèle qui est l'œuvre d'art elle-même."

${ }^{356}$ U.o. 1662. „Des mouvements á l'état naissant, qui ne peuvent pas encore être nommés, qui n'ont pas encore accédé á la conscience où ils se figeront en lieux communs, forment la substance de tous mes livres. Ils sont en constante transformation, en perpétuel devenir."

357 Tison-Braun (1970). p. 31. „larves malfaisantes, mais l'humain tué ou inéclos est en elles” 
szereplő-foglalatok szemben állnak, s többször megfigyelésük alá vonják a tropizmusellenséget ${ }^{358}$, akinek célja, hogy nyilvánvalóvá tegye, megnevezhetőnek állítsa be, fixálja az érzelmeket, szavakkal megragadhatóvá tegye az érzeteket. Több különböző Sarrauteszakirodalom is utalt már arra, hogy a Sarraute-művek szereplőfelfogása újraírja a klasszikus greimas-i szereplömodellt.

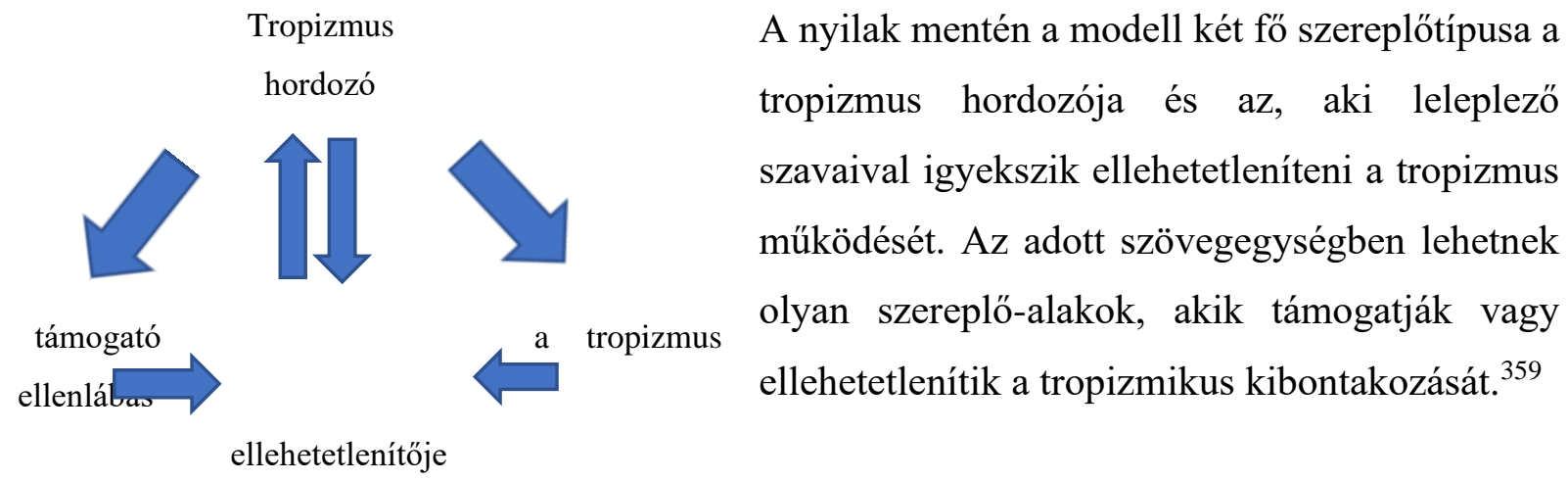

\section{Ryeker alapján Nipapolm modellje a} tropizmus viszonyainak leírására.

\section{VII.}

Pas devant lui surtout, pas devant lui, plus tard, quand il ne serait pas là, mais pas maintenant. Ce serait trop dangereux, trop indécent de parler de cela devant lui.

Elle se tenait aux aguets, s'interposait pour qu'il n'entendît pas, parlait elle- même sans cesse, cherchait à le distraire : « La crise... et ce chômage qui va en augmentant. Bien sûr, cela lui paraissait clair, à lui qui connaissait si bien ces choses... Mais elle ne savait pas... On lui avait raconté pourtant... Mais il avait raison, quand on réfléchissait, tout devenait si évident, si simple... C'était curieux, navrant de voir la naïveté de tant de braves gens. » Tout allait bien. Il paraissait content. Tout en buvant son thé, il expliquait de son air indulgent, sûr de lui, et il faisait

\begin{abstract}
VII.
Föleg ne előtte, csak őelőtte ne, majd később, amikor nem lesz itt, csak most ne. Különösen veszélyes volna, illetlen erröl beszélni előtte.

Az asszony lesben állt, közbelépett, hogy a férfi semmit ne halljon meg, maga kezdett beszélni szüntelen, igyekezvén elvonni a figyelmét: „A válság... és a folyamatosan emelkedő munkanélküliség. Ez magától értetődő, egész világosnak tünt, aki annyira jól ismerte az életet... De a felesége nem tudta... Noha neki is a tudomására hozták... Ám a férfinak igaza volt, amikor valaki belegondol, minden annyira nyilvánvalóvá válik, annyira egyszerúvé... Érdekes volt vagy inkább siralmas látni annyi egyszerü ember naivitását." Minden jól ment.
\end{abstract}

\footnotetext{
${ }^{358}$ U.o. p. 32. ennemi

359 Nipaporn Tirasait (2007). "Nathalie Sarraute: Tropisms and the drama of logos" in Journal of Humanities 10.2, 2007 p. 89.

Rykner, A. (1988). Théâtre du Nouveau Roman. Paris: José Corti

Rykner, A. (2000). Paroles perdues : Représentation et faillite du langage. Paris: José Corti.,
} 
entendre parfois, plissant la joue, pressant la langue contre ses dents de côté pour en chasser un reste de nourriture, un bruit particulier, une sorte de sifflement, qui avait toujours chez lui un petit ton satisfait, insouciant.

Mais il se produisait parfois, malgré tous les efforts qu'elle faisait, un silence. Quelqu'un, se tournant vers elle, demandait si elle avait été voir les Van Gogh.

« Oui, oui, évidemment, elle était allée voir l'exposition (ce n'était rien, il ne devait pas faire attention, ce n'était rien, elle écarterait tout cela du revers de la main), elle y était allée un de ces dimanches après-midi où l'on ne sait jamais que faire. Évidemment, c'était très bien.

Assez, assez maintenant, il fallait s'arrêter, ces gens ne sentaient donc rien, ils ne voyaient donc pas qu'il était là, qu'il écoutait. Elle avait peur... Mais ils ne s'en préoccupaient pas, ils continuaient.

Eh bien, puisqu'ils y tenaient, puisqu'elle ne pouvait pas les retenir - qu'ils les laissent donc entrer. Tant pis pour eux, qu'ils entrent pour un instant, Van Gogh, Utrillo ou un autre. Elle se mettrait devant eux pour essayer de les masquer un peu, pour qu'ils n'avancent pas trop, le moins possible, là, doucement, qu'ils marchent de côté docilement, longeant le mur. Là, là, ce n'était rien, il pouvait les regarder tranquillement : Utrillo était ivre, il venait de sortir de Sainte-Anne, et Van Gogh... Ah ! elle le lui donnait en mille, il ne devinerait jamais ce que Van Gogh pouvait tenir dans ce papier. Il tenait dans ce papier... son oreille coupée ! « L'homme à l'oreille coupée », bien sûr, il connaissait cela ? On voyait cela partout main- tenant. Et voilà. C'était tout. Il n'était pas fâché ? Il n'allait pas se lever, la repousser brutalement, marcher sur eux, le regard fuyant, honteux, la lèvre mauvaise, hideusement retroussée ?

Non, non, elle avait tort de s'inquiéter. Il comprenait très bien. Il était indulgent, amusé. Il faisait entendre, plissant la joue,
Elégedettnek tünt. Jóindulattól sugárzóan, önbizalommal telve, teáját kortyolgatva magyarázott, és néha hallhatóan arcát beszívva, nyelvét hátulról oldalsó fogainak vetve, jellegzetes, már-már sípoló zajjal igyekezett némi ebédmaradékot eltávolítani - e hars nyammogás lényének mindig valamiféle elégedett, gondtalan árnyalatot kölcsönzött.

Ám időnként, vendéglátójának minden erőfeszítése ellenére, csend ült közéjük. Valaki az asszony felé fordulva, megkérdezte, elment-e a Van Gogh-ot megtekinteni.

„Igen, természetes egyszerűséggel ment el megnézni a kiállítást (semmi sem történt, biztosan észre sem vette, semmi sem történt, elhessegette magától a gondolatot), azoknak a vasárnap délutánoknak az egyikén ment el körbejárni, amikor az ember nem tud magával mit kezdeni. Kimondottan jó volt."

Elég, most már elég, valahogy meg kellene öket fékezni, ezek az emberek nem érzékelnek semmit sem, nem látják, hogy itt van és mindent hall. Az asszony félt... ám nem törődtek vele, folytatták.

Hát jó, ha ennyire ragaszkodnak hozzá, mivel nem tudja őket visszafogni - hagyjuk, hogy elszabaduljanak. Az ő bajuk, hát lépjenek be egy pillanatra, Van Gogh, Utrillo vagy bárki más. Eléjük állt, hogy megpróbálja kicsit maszkírozni őket, hogy ne közelítsenek annyira, vagy a lehetö legkevésbé sem, oda, finoman szólva oldalt álljanak, engedve, a fal mellé. Jó, jó, semmi nem történt, már nyugodtan nézhetik őket: Utrillo részeg, épp most jött ki a Szent Annából és Van Gogh... Jaj! Már számtalanszor dugta a férfi orra elé, ő pedig soha nem találná ki, mit tarthat Van Gogh abban a papírcsomagban. Abban a papírban... a levágott fülét tartotta! „A levágott fülü férfi”, valóban, tudta, miről van szó? Már mindenhonnan ez köszön vissza. Ennyi. Ez minden. A férfi nem bosszankodott? Nem kelt föl, lökte el durván a nőt, hogy rájuk taposson, elvesző, 


\begin{tabular}{|l|l|}
\hline $\begin{array}{l}\text { son petit sifflement, et l'on voyait toujours } \\
\text { au fond de ses yeux ce gai reflet, cette lueur }\end{array}$ & $\begin{array}{l}\text { szégyenteljes pislogással, ocsmányul } \\
\text { qui exprimait un sentiment placide de } \\
\text { visszahúzott ajkakkal? } \\
\begin{array}{l}\text { certitude, de douce sécurité, de de } \\
\text { contentement. }\end{array}\end{array}$ \\
$\begin{array}{l}\text { Nem, nem, az asszony alaptalanul aggódott. } \\
\text { A férfi nagyon jól értette. Jóindulatú volt és } \\
\text { engedékeny. Hallatta arczacskója beszívott } \\
\text { sípoló cuppogását, és továbbra is látható volt } \\
\text { a tekintete mélyén az a vidám } \\
\text { visszatükröződés, az a fel-feltörő fény, } \\
\text { amely a bizonyosság érzésének, e kedves } \\
\text { elégedettségnek nyilvánvaló kifejeződése } \\
\text { volt. }\end{array}$ \\
\hline
\end{tabular}

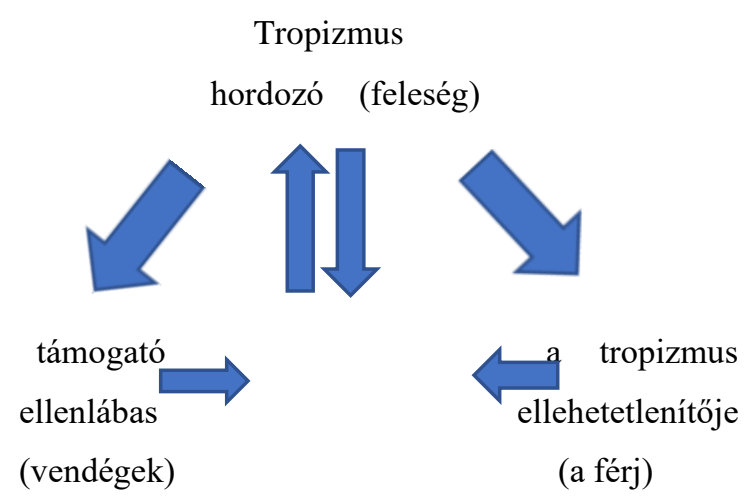

A Tropizmusok VII. szövegében a tropizmus szereplöinek viszonyai
A VII. szövegben a tropizmus megélöje a feleség. Ö az, aki érzékeny és nyitott a nonverbális szint kitapogatására, megélésére. Tisztában van azzal, hogy a kulturális-müvészeti témák a társaságban mennyire férje nyugalma ellen vannak. Ezért kerüli öket. Félelme nem realizálódik szavakban, csak nonverbális jelek utalnak rá. A vendégek nem érzékelik lelki csendjében megélt szenvedését.

„Főleg ne előtte, csak őelőtte ne, majd később, amikor nem lesz itt, csak most ne.” A szöveg nem pontosítja, mi az, amit nem lehet és ki előtt. Később derül ki az utalásokból, amelyekből egyértelműen kirajzolódik a beszédhelyzet, hogy a szövegegység minidrámájának konfliktusát az asszony a tropizmus szintjén éli meg: „,különösen veszélyes volna, illetlen (a kulturális eseményekről) beszélni előtte.” Az asszony a látszat szintjén, klisék, sztereotipikus nyelvi elemek segítségével igyekszik minden tőle telhetőt megtenni azért, hogy valamennyi intellektuális beszédtémáról elterelje a társaság figyelmét. A férjétől való félelem belső konfliktusa kirajzolódik kapkodó, csapongó szóhasználatában. A férjéhez való viszony látásmódja a házastárs evés közbeni mozgássorának részletező, felnagyított optikájú, már-már ironikussá tágított leírásából ismerhető meg. Az evés, a feleség által a férfinak való ételkészítés a házasságnak valamiféle metaforikus ábrázolása, s az ezzel kapcsolatos pejoratív szemléletü leírás a házasfelek kommunikációképtelenségének, belső magányának képsora: 
„Jóindulattól sugárzóan, önbizalommal telve, teáját kortyolgatva magyarázott, és néha hallhatóan arcát beszívva, nyelvét hátulról oldalsó fogainak vetve, jellegzetes, már-már sípoló zajjal igyekezett némi ebédmaradékot eltávolítani - e hars nyammogás lényének mindig valamiféle elégedett, gondtalan árnyalatot kölcsönzött."

Nipapolm sémáját követve a vendégek szerepe, hogy verbalizálják a mélyen lappangó, csak testi érzetekben, a látásmód egyénítettségében, a szóklisékben lüktető tropizmust, mintegy térdre kényszerítve a feleséget. „Valaki az asszony felé fordulva, megkérdezte, elment-e a Van Gogh-ot megtekinteni.” A nő hiába próbálja kulturális érdeklődését bagatellizálni (,„a vasárnap délutánoknak az egyikén ment el körbejárni, amikor az ember nem tud magával mit kezdeni”), tudja, hogy tiltott területre tévedtek, s félelme kitapintható. A szövegegység vége felé a tropizmikus mozgássor fordulatot vesz azzal, hogy valójában a vendégek sem a magas kultúra szintjén tematizálják a nőt érdeklő, a férfit pedig önbizalmától megfosztó intellektuális érdeklődésre számot tartó müvészeti eseményeket. „Utrillo részeg, épp most jött ki a Szent Annából és Van Gogh... Jaj! Már számtalanszor dugta a férfi orra elé, ő pedig soha nem találná ki, mit tarthat Van Gogh abban a papírcsomagban. Abban a papírban... a levágott fülét tartotta!"

A vendégek szerepköre ilyen értelemben nem csak az, hogy kitaszítsák a nőt a tropizmus csendvilágából, hanem éppen ellenkezőleg, ők azok, akik segítik oda visszatalálni anélkül, hogy a férfi és a nő valódi játszmája vagy konfliktusa verbalizálódna. A házastársi konfliktus lehetőségének már-már ironikus, filmes, snittszerü bevágása: „nem kelt föl, lökte el durván a nőt, hogy rájuk taposson, elvesző, szégyenteljes pislogással, ocsmányul visszahúzott ajkakkal" - arra utal, hogy a tropizmus szintjén a minidráma megoldódott, lezajlott, s a megoldás inkább komikus mint tragikus. A házasfelek szavak nélküli játszmája helyreáll, ezt abból a nonverbális jelből tudjuk, amely már a szöveg első felében is a férji elégedettség metonimikus megidézése volt: „hallatta arczacskója beszívott sípoló cuppogását”.

A szövegrészben tehát a szereplö-alakok állnak szemben a tropizmus-foglalat feleséggel. Személyükről kizárólag testi megnyilvánulásaik leírásának utalásrendszeréből nyerünk ismeretet, illetve azokból a verbális klisékből, amelyeket a szöveg beidéz.

\section{3. A tropizmus mint müfaj}

Két genette-i terminus, a fikció és a dikció szinte kínálkozik, hogy közelebb hozzuk azokat a formai változásokat, amelyek Sarraute prózájában megvalósulnak. Kis különbséggel mindkét szerző egy gyékényen árul: Sarraute esszéistaként és szépíróként egyaránt azon van, 
hogy az antireprezentáció poétikáját fikcionális müveiben megvalósítsa, Genette pedig, kizárólag elméletíróként a müfajok átjárhatóságát hirdeti: a nem reprezentációs szövegtípusok az ő rendszerében is képezhetnék a reprezentációs paradigma szerves részét. ${ }^{360}$

Genette ellene mond az arisztotelészi hármas műnem-felosztásnak, és felvázolja az architextuális müfajiság koncepciójának körvonalait úgy, hogy mindehhez segítségül hívja a transztexutalitás fogalmát. ${ }^{361}$ 1991-ben újra foglalkozni kezd ugyanezzel a témával, a müfajiságnál általánosabb szempontokat alapul véve: az irodalmiság kérdését feszegeti. ${ }^{362}$ Genette úgy képzeli el egy az új, posztmodern szövegvilágok tekintetében helyét megálló müfaji taxonómia érvényesítését, hogy szembehelyezkedik az arisztotelészi mimetikus irodalmiság-koncepcióval, amely, mint mondja, hármasságra szorítkozó műnemelméletének teoretikus alapja. Genette elsősorban azzal oszlatja el az arisztotelészi münemelmélet érvényességéről szóló elképzeléseket, hogy kijelenti: Arisztotelész, akárcsak Platon nem beszélt müfajokról, hanem reprezentációs módokról (elbeszélőkről és drámaiakról). Ezért van az, hogy a reprezentációs kritérium az irodalomtörténetírás során végig az irodalmiság első számú feltételévé nőtte ki magát, jegelve ezzel annak lehetőségét, hogy dinamikusabb műfaji rendszerben gondolkodjunk.

Ez az elméleti megalapozás elegendő Genette számára ahhoz, hogy feltegye a kérdést: hogyan lehetne a reprezentációs münemek, s ilyenformán műfajok (epika - regény, novella, dráma) rendszerébe teljes elméleti megalapozottsággal beilleszteni a nem reprezentációs müfajokat (líraiság, önéletírás, esszé, filozófia) ${ }^{363}$ A fikció és a dikció közötti különbségtétel azt sugallja, hogy egy epikai szöveg ,irodalmisága” vagy fikcionális jellegéből adódik, eredeztethető („konstitutív, esszenciális irodalmiság”, „fikcionális irodalmiság”), vagy olvasóként elsősorban azt értékeljük, hogy milyen nyelvi formába öntötte a szerző a gondolatot („dikció alapú irodalmiság”) ${ }^{364}$ A müfajelmélet ebben a formájában nem más, mint poétikai vizsgálódás, és folyománya egyfajta kétosztatú rendszer. ${ }^{365} \mathrm{~A}$ klasszikus műnemi

\footnotetext{
${ }^{360}$ Genette, Gérard (1979). Introduction à l'architexte, Paris, Seuil

Genette, Gérard - Todorov, Tzvetan (1986). Théorie des genres, Paris, Seuil, p. 153.

${ }^{361}$ Uo.

362 Genette, Gérard, Fiction et diction, Paris, Seuil, 1991.

${ }^{363}$ Genette - Todorov (1986). p. 153

Genette, Gérard (2003) "Fiction ou diction", Poétique, avril 2003, n 134, p. 131-139.

${ }^{364}$ Genette (2003). p. 134.

365 Jolles, André (1972). Formes simples, Paris, Seuil, p. A klasszikus háromosztatú rendszer „megdöntése” már a Genette előtti elméletírásnak is szerves része volt: André Jolles három elbeszélőmódról értekezik - kérdező, kijelentő, csend, felszólító és választó jellegü beszédmódokról és azt mondja, hogy mindegyik elbeszélői típus két altípusban valósulhat meg: vagy a realista, vagy az idealista altípusban.

Todorov, Tzvetan (1978). Les genres du discours, Paris, Seuil. Todorov is arról értekezik, hogy az irodalmi és a nem irodalmi szövegek egyaránt számos különféle szövegtípus segítségével realizálódhatnak.
} 
hármasság (epikus, drámai és lírai) a fikcionális irodalom szövegeire korlátozódik, és feltételezi, hogy a szöveg célja, hogy elmondjon egy cselekményt a szereplök mozgatása segítségével, és a különféle narratív és drámai írástechnikák célszerü alkalmazásával. Ezzel párhuzamosan ugyanakkor kibontakozni látszik egyfajta „dikcióra alapuló irodalom” (önéletírás, esszé, szöveget, stílust hangsúlyozó irodalmiság), melynek esztétikai értékét láthatóan nem a szövegből kirajzolódó történet adja, hanem maga a nyelvi megformálás, s ilyenformán célja nem egy cselekmény mimetikus ábrázolása, hanem gondolatokra és érzelmekre való szövegközpontú utalásrendszer közvetítése. ${ }^{366}$

Elméletével Genette nem csak Arisztotelész örökségére reagált, hanem az irodalmiság újfajta fogalmáról elmélkedve Roland Barthes koncepciójával is szembekerült, aki az ötvenes és a hatvanas években kidolgozza az irodalomelmélet tisztán immanens vonulatának koncepcióját. ${ }^{367}$ Barthes elmélete elkerüli a müfajok kérdését, nem alkalmaz műfajkritikát. Az autoreferenciális, önmagának elégséges, autotelikus szövegelmélet részeként nyilvánvaló, hogy nincs szükség kívülről a szövegre aggatott műfaji megnevezésekre. ${ }^{368}$

Meg kell jegyeznünk ugyanakkor, hogy az autotelikus irodalomelmélet mentén fogalmazza meg Blanchot, Derrida vagy Deleuze a müfajisággal kapcsolatos álláspontját. „A szövegek nem alkalmasak arra, hogy müfaji szempontból besoroljuk őket. Minden szöveg csatlakozik egy vagy akár több műfajhoz, így tehát mindig van műfaj vagy vannak műfajok, ám a besorolás helyett erre a kapcsolódás a megfelelő kifejezés" - fogalmaz Derrida. ${ }^{369}$ Blanchot ugyanakkor megjegyzi, és ezzel radikálisan le kíván számolni a müfaj fogalmával: „A könyvek nem tartoznak müfajokba, minden könyv az irodalom részeként tételezhető..."370 Deleuze nem ítéli el a müfaji besorolás tényét, nem is zárkózik el tőle, inkább igyekszik meghatározni, vajon mi lehet az oka: „Manapság egyenlítői és antarktikus sávok cselekvő tenyészete hatja át mérsékelt civilizációnk közegét - rejtőzködnek a fajok, a nemek, az osztályok, a rendek különbségtétele elöl."371

\footnotetext{
${ }^{366}$ Genette (2003). p. 133-134.

${ }^{367}$ Genette - Todorov (1986). p. 155-159. Elméleti vitájuk gyakorlati kivetülése az a képzelt párbeszéd, vita, amelyet megtalálunk: A beszélgetőpartner neve Frédéric (talán Lejeune ?), de szövegelmélete megfelel Barthes teoretikus koncepciójának.

368 Dessons, Gérard (2000) Introduction à la poétique, Paris, Nathan, p. 118.

${ }^{369}$ Derrida, Jacques, (1986) Parages, Paris, Galilée, p. 264. „Un texte ne saurait appartenir à aucun genre. Tout texte participe d'un ou de plusieurs genres, il y a toujours du genre et des genres mais cette participation n'est jamais appartenance."

370 Todorov (1975). p. 45. idézi Blanchot, Maurice, (1959). Le livre à venir, Paris, Gallimard, p. 136, $243-244$. „Un livre n'appartient plus à un genre, tout livre relève de la seule littérature...”

${ }^{371}$ Deleuze, Gilles - Guattari, Félix (1991). Qu'est-ce que la philosophie ? Paris, Éd. de Minuit, p. 164. „C'est dans les milieux tempérés de notre civilisation qu'agissent et prospèrent actuellement les zones équatoriales ou glaciaires qui se dérobent à la différenciation des genres, des sexes, des ordres et des règnes."
} 
Ugyanakkor Genette Barthes-tól nyer ihletet, amikor az írót écrivant-nak ${ }^{372}$ nevezi, vagy akár Lévi-Strauss fogalmával bricoleurnek ${ }^{373}$. Ö maga is kínál egy sajátos fogalmat az íróra: hibrid ${ }^{374}$. Ez egy olyan író, aki a deleuze-i szóhasználatot alapul véve folyamatos leendésben, van, s akinek életműve mindig a „kettőközöttiség” állapotában van: „a leendés nem egy, nem is kettő, nem is egy és kettő kapcsolata, hanem kettőközöttiség, határ vagy szökésvonal." 375 Nathalie Sarraute életműve különösen jó példája ennek a hibriditásnak, a kettőközöttiség állapotának: fikció és dikció között helyezkednek el a szövegei. A fikcionális narratíva nem hordozza többé szövegeiben a klasszikus, reprezentációs írói eljárásokat. Nincs mit bemutatni, valószerüen ábrázolni, hiszen a világ nem több mint homlokzat, „látszat”, „közhely”376.

Mi is ez? Egyfajta igazság- vagy eredetiségkeresés? ${ }^{377}$ A felszín, a homlokzat, a látszat hazugságretorikájának ${ }^{378}$ Sarraute ellene szegezi a dikció eredetiségét. Ugyanakkor a fikció szintjén nem „,produkálja”, ábrázolja a nevezetes „emberi tetteket, cselekvéseket”, amelyek a mimézis alapvető kellékei, hanem egyenesen az élő lüktetés, a Deleuze által „körülhatárolhatatlannak” nevezett szómögöttes verbalizálására tör. „Csak az élet képes efféle sávok megalkotására, ahol nyüzsögnek az élők, és csak a művészet képes elérni e sávot, valamint belehasítani az együtt-alkotás bevállalásával...”379 A sarraute-i fikciós alkotások irodalmisága tehát dikciójukban áll a mimetikus ábrázolás szabályainak áthágása folytán. Esszéi pedig forrásukat saját fikciós műveinek alkotásmódjából merítik: ezek maguk sem mentek a szómögöttes megjelenítésétől.

„Regényszerủ szövegegységről van szó, amely a regénynél sokkal eszköztelenebb - ráadásul néha csupán egy-két sor -, sem nem elbeszélés, mert benne az anekdota tudatosan eljelentéktelenített, sem tabló, mert benne a leírás a minimumra szorítkozik, és még epizód sem, mert teljesen hiányzik belőle a folyamatszerüség." 380

\footnotetext{
372 Barthes, Roland (1960). "Écrivains et écrivants", Arguments Elérhető: http://aelib.org.ua/texts/barthes_essais_critiques_fr.htm\#07 Letöltés ideje: 2020.01.06.

373 U.o. p. 135.

${ }^{374}$ U.o. $135-136$.

375 Deleuze, Gilles (1980). Mille plateaux, Paris, Éd. de Minuit, p. 360. "...le devenir n’est ni un ni deux, ni rapport de deux mais entre-deux, frontière ou ligne de fuite."

${ }^{376}$ Sarraute, Nathalie (1956). p. 9.

377 Gosselin-Noat, Monique (2002), "Nathalie Sarraute et la recherche de la vérité", Critique, janvier-février 2002, tome LVII, n 656-657, p. 22-35.

378 U.o. p. 12-13.

${ }^{379}$ Deleuze-Guattari (1991). p. 164. indétermination

380 Tison-Braun (1971). p. 25. „C'est une unité romanesque beaucoup plus restreinte - limitée parfois à quelques lignes - qui n'est ni récit, puisque l'anecdote y est volontairement rendue insignifiante, ni tableau puisque la description y est réduite au minimum, ni épisode puisqu'elle se passe de continuité (...)”
} 
Ez az a nem...nem... sem..., ami miatt egy ütemre lélegzik a sarraute-i prózapoétikában esszé és regény, dikció és fikció, amelyek egymást váltják és kiegészítik, hol megelőzve, hol lehagyva egymást. Egyfelől a Tropizmusok, amelyek elvileg a fikciós irodalom körébe tartoznának, több dikciós irodalmi jegyet hordoznak. Másfelől A gyanakvás kora, amely elvileg a dikciós irodalom körébe tartozik, a fikciós irodalom stílusjegyeivel él.

\section{4. Nathalie Sarraute tropizmusai - a szereplő feloldódása fikció és dikció között}

Melyek a Tropizmusok mint fikciók dikciós jegyei? Az alkotó elbizonytalanítja az olvasót három, a hagyományos elbeszélésben nélkülözhetetlen, alapvető narratív követelmény tekintetében: cselekmény (mi történik), szereplő (kivel) és hely (hol). Ezeket a hiányokat Sarraute diszkurzív eljárásokkal tölti ki: megnevezés, rámutatás, körülírás, leírás, jellemzés helyett a fikciót dikcióval helyettesíti, azaz nyelvi-stilisztikai megoldásokkal sugall, érzékeltet. ${ }^{381}$ Szétfeszíti, nem csak a szöveget, még a mondatot is, kihagyásokkal, ki nem mondott szavakkal, hangokkal játszik. Mondhatnánk, hogy költői a szöveg, de mivel mindig élet- és beszédhelyzetből indul ki, mélységesen prózai marad alkotói módszere ${ }^{382}$.

\section{Tropizmus VI. rész}

Le matin elle sautait de son lit très tôt, courait dans l'appartement, âcre, serrée, toute chargée de cris, de gestes, de halètements de colère, de "scènes". Elle allait de chambre en chambre, furetait dans la cuisine, heurtait avec fureur la porte de la salle de bains que quelqu'un occupait, et elle avait envie d'intervenir, de diriger, de les secouer, de leur demander s'ils allaient rester la une heure ou de leur rappeler qu'il était tard, qu'ils allaient manquer le tram ou le train, que c'était trop tard, qu'ils manquaient quelque chose par leur laisseraller, leur négligence, ou que leur déjeuner était servi, qu'il était froid, qu'il attendait depuis deux heures, qu'il était glacé.... Et il semblait qu'á ses yeux il n'y avait rien de plus méprisable, de plus bête, de plus haïssable, de plus laid, qu'il n'y avait pas de
Reggel az asszony roppant korán kelt, keresztül-kasul száguldott a lakásban, keserü kiáltás, dühös jajszó, készülődő „jelenet” nyomta-feszítette. Szobáról szobára járt, bekukkantott a konyhába, haragos noszogatás a fürdőszoba ajtaján, azt éppen elfoglalták, ö kész volt arra, hogy közbelépjen, rájuk ripakodjék, kijajveszékelje őket, vagy hogy megkérdezze tőlük, maradnak-e még egy órát, emlékeztetett, hogy későre jár, le fogják késni a villamost, a vonatot és már túl késő lesz, s mindez köszönhető a hányaveti nemtörődömségüknek, az ebédjük is tálalva, vagy már ki is hült, mindenesetre két órája készen van, mindjárt megdermed... Úgy tünt, a szemében semmi sem annyira megvetendő, mint inkább buta, gyülöletes, rút $\mathrm{s}$ az alacsonyabb rendüségnek,

\footnotetext{
${ }^{381}$ Herschberg-Pierrot, Anne, La stylistique de la prose, Paris, Belin, 1993, p. 243.

382 Maulpoix (2002)
} 
signe plus évident d'infériorité, de faiblesse, que de laisser refroidir, que de laisser attendre le déjeuner.

Ceux qui étaient des initiés, les enfants, se précipitaient. Les autres, insouciants et négligents envers ces choses, ignorant leur puissance dans cette maison, répondaient poliment, d'un air tout naturel et doux : " Merci beaucoup, ne vous inquiétez pas, je prends très volontiers du café un peu froid. » Ceux-là, les étrangers, elle n'osait rien leur dire, et pour ce seul mot, pour cette petite phrase polie par laquelle ils la repoussaient doucement, négligemment, du revers de la main, sans même la considérer, sans s'arrêter un seul instant à elle, pour cela seulement elle se mettait à les haïr.

Les choses ! les choses ! C'était sa force. La source de sa puissance. L'instrument dont elle se servait, à sa manière instinctive, infaillible et sûre, pour le triomphe, pour l'écrasement.

Quand on vivait près d'elle, on était prisonnier des choses, esclave rampant chargé d'elles, lourd et triste, continuellement guetté, traqué par elles.

Les choses. Les objets. Les coups de sonnette. Les choses qu'il ne fallait pas négliger. Les gens qu'il ne fallait pas faire attendre. Elle s'en servait comme d'une meute de chiens qu'elle sifflait à chaque instant sur eux : «On sonne ! On sonne ! Dépêchez-vous, vite, vite, on vous attend ». Même quand ils étaient cachés, enfermés dans leur chambre, elle les faisait bondir : " On vous appelle. Vous n'entendez donc pas ? Le téléphone. La porte. Il y a un courant d'air. Vous n'avez pas fermé la porte, la porte d'entrée ! » Une porte avait claqué. Une fenêtre avait battu. Un souffle d'air avait traversé la chambre. Il fallait se précipiter, vite, vite, houspillé, bousculé, anxieux, tout laisser là et se précipiter, prêt à servir. gyöngeségnek sincs nyilvánvalóbb jele, mint hogy valaki hagyja elhülni, megbörösödni a levesét.

A beavatottak, a gyerekek, sietősre fogták a tempót. A többiek, a gondtalanok, akik nem törődtek az efféle földi hívságokkal, nem ismerték azok hatalmát ebben a házban, udvariasan válaszolták lágy természetességgel: „Ó köszönöm, ne aggódjék, szívesen iszom hidegen is a kávét." Ezeknek az idegeneknek nem mert semmit sem mondani, s ezért e nyájas hálálkodásért, ezekért az udvarias mondatokért, amelyek finom nemtörödöm szófukarsága kezük egy legyintésével inkább hárította közeledését, mint hogy tekintetbe vette, vagy akár egy pillanatra is valamire méltatta volna - csupáncsak ezért gyülölni kezdte őket.

Használati tárgyak! tárgyak! Ereje forrásai. Hatalma ezekben rejlik. Ezt vetette be a maga ösztönös, tévedhetetlen és magabiztos módján, hogy győzelemre törjön, teljes megsemmisítésre.

Amikor valaki a közelségében él, a rutin fogságának jármába hunyászkodó bús rabszolga, akkor nehézkes lesz, mint akit tárgyak nógatnak, hajszolnak.

Kéznél lévő tárgyak. Dolgaink. Csengetések. Nem lehet nem figyelembe venni. Emberek, akiket nem lehet megváratni. Úgy él velük, akár egy falka kutyával, mely minden pillanatukban rájuk vicsorít: „Csöngetnek! Siessenek, gyorsan, hamarjában, várják magukat."

Még akkor is, amikor bezárkózva meglapulnak a szobájukban, kiugrasztja őket: „Hívják magokat. Nem hallják? Csöng a telefon. Nyílik az ajtó. Huzat van. Nem csukták kilincsre az ajtót, a bejárati ajtót!" Becsapódott egy ajtó. Csattant egy ablak. A szobát fuvallat szelte. Sietni kellene, iparkodva, megszidottan, toszigálva el mindent az útból, szorongón, mindent hátraés meghagyva, rajt, igyekezvén a szolgálatra.

A szövegben a fikció klasszikus elemei, a szereplö, a helyszín csak metonimikusan, szinekdochikusan felismerhetők. A szereplöre utalnak az igék, ezekből derül ki, milyen típusú 
tevékenységeket folytat: „korán kelt”, „száguldott”. A tropizmus kibontakozásának helyszínére utaló részletek, „a lakás tágas helyiségei” nem önálló leírásként, hanem a megidézett asszony viselkedésével összefüggésben szerepelnek a szövegben. A fürdőszoba, a szobák száma és az igeragozásokból E/3-ban kirajzolódó szereplő-alak magatartásmintáinak szinekdochikus utalásrendszere az úri lakóház vagy panzió vonatkozásában jelenhetnek meg. A tropizmus által megjelenített személyre megnevezés hiányában nem vonatkozik referenciális funkció. Az igeragozás szerepe (E/3) nem anaforikus, nem utal vissza valami megnevezettre, hanem a dikció alapja. A szöveg nem ábrázolja (fikció) az asszony tetteit, kilétét, valamint jellemét, hanem képekben festi, az igék, melléknevek és a főnevek szemanikájának segítségével (dikció): „rájuk ripakodjék”, „kijajveszékelje”, „,nemtörődömség”, „hányaveti”. Beidézett, visszhangtalanságuk miatt monologizáló megszólalásának foszlányai, például: „megkérdezze tőlük, egy órát maradnak-e még s emlékeztetett, hogy későre jár, le fogják késni a villamost” felfednek valamennyit gondolkodásmódjából, s ezáltal Sarraute nem mimetikus megnyilatkozást, hanem metonimikus dikciót hoz létre.

Ugyanez a szövegmegformálás jellemzi a topizmus mellékszereplöinek megjelenítését: „kedve lett volna megrázni őket”. Az őket személyes névmás itt is előkép nélküli. Antecedens hiányában nincs referenciális funkciója, az olvasó metonimikus utalásokból következtet: például melléknévvel utal rájuk: „gondtalanok”, a fönév szemantikájával: „földi hívságok”, és a hozzá tartozó ige szemantikájával: „nem törődnek vele". Megjelenik a szokásos klisé is, a kifejezés alapmódozata, a megszólalás közhelyszerüsége, az udvarias elhárító mechanizmus idézése: „Ó köszönöm, ne aggódjék.”

„A beavatottak, a gyerekek, sietősre fogták a tempót. A többiek, a gondtalanok, akik nem törődtek az efféle földi hívságokkal, nem ismerték azok hatalmát ebben a házban, udvariasan válaszolták lágy természetességgel: „Ó köszönöm, ne aggódjék, szívesen iszom hidegen is a kávét.”

Tehát az igékben megjelenített cselekvéssorok helyettesítik a jellemzést, a helyiségek és a szereplök kapcsolata pedig a helyszín leírása helyett ál. A közösen tálalt ebéd, a kihült kávé, az udvariaskodó visszautasítások sora utal a tropizmus főszereplőjének szenvedéstörténetére. A tropizmus vége felé ugyanakkor egyfajta külső, klasszikus mindentudó narrátori nézőpont jelenik meg.

„Ezeknek az idegeneknek nem mert semmit sem mondani, s ezért e nyájas hálálkodásért, ezért ezen udvarias mondatokért, amelyek finom nemtörődöm szófukarsága kezük egy legyintésével inkább hárította közeledését, mint hogy tekintetbe vette, vagy akár egy pillanatra is valamire méltatta volna csupáncsak ezért gyülölni kezdte őket." 
A fikció cselekménysorának hiányait tehát a dikció metonimikus eljárásokkal tölti ki. Sem a tropizmus főszereplőjének nevét, sem társadalmi hovatartozását, sem a foglalkozását közvetlen referenciális nyelvi eszközökkel nem közli a szerző, ugyanakkor a portré mégis kirajzolódni látszik, és mint említettük, a metonimikus utalásrendszeren kívül a szerző felhasználja a klasszikus prózapoétika néhány eszközét is: az érzelmek leírásán túl megjelennek a szereplő tulajdonságainak festése ${ }^{383}$ a melléknevek szemantikájának felhasználásával. „Használati tárgyak! tárgyak! Ereje forrásai. Hatalma ezekben rejlik. Ezt vetette be a maga ösztönös, tévedhetetlen és magabiztos módján, hogy győzelemre törjön, teljes megsemmisítésre."

A VI. rész első felének metonimikus utalásrendszerét a második részben a fogvatartófogvatartott kölcsönös függésének képe váltja fel, átadva a metonímia helyét a metaforikus utalásrendszernek. „Amikor valaki a közelségében él, a rutin fogságának jármába hunyászkodó bús rabszolga, akkor nehézkes lesz, mint akit tárgyak nógatnak, hajszolnak". A „fogság”, ,járom”, „hunyászkodó”, „rabszolga”, „,nehézkes”, „,nógat, hajszol” szavak mind metaforikusan idézik meg az alávetettség képsorait, legyen az ember-ember vagy akár emberállat viszonyrendszerében megjelenő függőség. „Emberek, akiket nem lehet megváratni. Úgy él velük, akár egy falka kutyával, mely minden pillanatukban rájuk vicsorít: 'Csöngetnek! Siessenek, gyorsan, hamarjában, várják magukat." " A szövegzárlatban a kutya képe egyrészt a teljes függőséget egyértelmüsíti, másrészt a fenyegető attitüdöt.

Talán nem is azt lehet mondani, hogy teljességgel hiányoznak a tropizmus megjelenítéséből a klasszikus prózapoétikai eszközök, inkább a hangsúlyok csúsznak el. Az érzelmek festése helyett e második részben a panzió lakói metaforikusan a fogvatartottak, míg a szállásadónő fogvatartóként való megjelenítése finom utalásként magában hordozza az udvarisas látszat mögötti kölcsönös függést, a rend fenntartásának sziszifuszi munkáját az egyik oldalon, a másikon pedig a függetlenedés, az önálló életvitel vágyát és ellehetetlenülését. Az állattartás allegóriája itt toposzként jelenik meg, klasszikus világirodalmi utalásrendszerbe kapcsolva a VI. számú tropizmus mikrovilágát. A fikció jelenléte nem kérdéses tehát, de az elbeszélés eszköztára a dikciót helyezi előtérbe.

Az orosz formalisták ezt indirekt karakterizációnak nevezték, a név kötelez, előrevetíti a szereplő lélektani beállítódását. Ugyanakkor a szereplő-alak háttereként ábrázolt helyszín is szemantikailag többszörözi, támogatja sorsának megrajzolását. A helyszínleírás metaforikus vagy metonimikus eszközökkel gazdagítja a hozzá kapcsolható jelentésrétegeket, a

\footnotetext{
${ }^{383}$ Milly, Jean (1992). Poétique des textes, Paris, Nathan, 1992, p. 139.
} 
konnotációt müködésbe hozó szövegbelső hullámzással, gyakori megszemélyesítő vonatkozásaival szervezi a szereplő szemantikai-konnotatív szövegkörnyezetét. Ez az írástechnika többször szerepel Nathalie Sarraute prózájában.

A sarraute-i szöveg dikció és fikció között áll, e kettőközöttiség, bizonytalan sáv megléte a fikcionális narratíva mankóinak elutasításából, átformálásából adódik, ugyanakkor esszéiben is alkalmazza a szómögöttes felszínre hozatalának poétikáját. Jean-Yves Tadié egyenesen úgy fogalmazza meg, hogy A gyanakvás kora nem más, mint gondolatregény. ${ }^{384}$ Utolsó esszéje, az Amit csak a madarak látnak tematizálja a szómögöttest mint poétikai eszközt. A gyüjtemény alcíme szerint esszéket olvashatunk a kötetben a regényről. Az első esszé (Dosztojevszkijtöl Kafkáig) a műfaj történetét eleveníti fel, a második és a harmadik (A gyanakvás kora, Párbeszéd és szómögöttes), az utolsó a műfaj jövőjét igyekszik felvázolni. Az olvasóközönség központi szerepet játszik a sarraute-i regénykoncepcióban, főleg a műfaj jövőjét illetően. Az imitációs irodalmiság kötöttségeitől való szabadulást tűzi ki fő célként (mimézis, fikció, portré,- és jellemalkotás - szereplő, hős), tehát ennek az írói ambíciónak a folyományaként nagy szüksége van az olvasóra mint alkotótársra, akinek számot tat értelmezői képességére. Ezért van az, hogy Sarraute utolsó esszéjét a laikus és szakmai közönség témájának szenteli, és az eddig fikcionális müveiben alkalmazott a szómögöttes poétikai eljárással dolgozza fel. Ha a tropizmus színre léptetése nem más, mint a klasszikus cselekmény helyettesítése, akkor a szómögöttes különböző diszkurzív eljárásai (belső monológ, képek, emléksorok, nonverbális jelek festése, szavak szemantikájának metonimikus utalásrendszere) arra hivatottak, hogy ráirányítsák az olvasó figyelmét a tropizmus mögött meghúzódó titkos világokra. A tropizmus, vagy továbbmenve a szómögöttes tehát az a sáv, amelybe belépve az író és az olvasó egységet képezhetnek, képesek közösséget alkotni vagy akár egy nyelvet beszélve megérteni egymást végre. Nem más, mint az írás és az olvasás közös alapja. ${ }^{385}$

Nathalie Sarraute írásmüvészete mimézis szempontjából tehát abban a körülhatárolhatatlan sávban található, a kettőközöttiségben, abban a leendésben, amely fikció és dikció határán egyensúlyoz. Alkotóként a hibrid megtestesítője, akinek művészete ugyanakkor immár klasszikus.

\footnotetext{
384 Tadié, Jean-Yves, "Un traité du roman", L’Arc 95, 1984, p. 55-59. roman d'idée ${ }^{385}$ U.o., p. 58.
} 


\section{V.5. A Tropizmus idővonatkozásai}

Az egész világ időben és a térben helyezkedik el. Az idővonatkozások kérdésköre az irodalomértelmezés egyik legérdekesebb pontja. A történet, a hely, a szereplő aspektusai egyszerübben megragadhatóak, de az idő sokszor, sőt legtöbbször az egyik leginkább megfoghatatlan mozzanata az irodalmi műveknek. „A temporalitás, annak felfogása és felfoghatatlansága is a conditio humánához tartozik.” ${ }^{386} \mathrm{Az}$ időfelfogás alapvetően nézőpont, a Lét és a Levés közötti dilemma. Shakespeare tragédiáiban „kizökkent az időként” fordul elő, hősei reflektálnak az időre, de mindegyikük saját neme, helyzete, szerepe szerint. „A szépirodalmat a Lét csak mint Levés foglalkoztatja" ${ }^{387}$. Heller Ágnes hontalanságnak ${ }^{388}$ nevezi azt, amikor kívül helyeződünk időn és téren - Deleuze nomadológiáról ${ }^{389}$ beszél. Az idő a klasszikus filozófai felfogásban vagy az ismétlés vagy a halandóság ${ }^{390}$. Kierkegaard-nál ugyanakkor már megjelenik a pillanat olyan elgondolása, mint ami az idő és az örökkévalóság metszéspontján képzelhető el ${ }^{391}$. A XIX-XX. századi filozófiában jól elkülöníthető az objektív és a szubjektív időfogalom- és felfogás. Az objektív idő, óra-idő, mechanikus idő, üres, kiüresedett idő, az idő nyomása, az idő uralma mind-mind olyan gondolati sémákká váltak, amelyek a filozófiai szemléletmódból kivetültek az irodalmi beszédmódokra. Innen továbblépve olyan élettörténeteket kezdtek a hősök megjeleníteni a XX. századi irodalomban, amelyek egyre inkább tartalmukkal és nem értelmükkel ${ }^{392}$ voltak mérhetők. Itt elsősorban Sartre vagy Camus hőseire gondolok, akiknek felrajzolásakor már az abszurd szerzői elszakadnak a klasszikus idővonatkozástól: nem deríthető ki, mi miért történik velük, csak az, hogy mi történik velük. Ezzel párhuzamosan persze Flaubert és Bergson nyomán a szubjektív idő, belső idő, élményidő, álom, belső történés, autentikus idő, belső idődimenzió, emlékek, eredendő gondolkodás, eredendő tevékenység, autentikus ismétlés vonatkozásai alakot öltenek az irodalmi mủvekben, többek között a Sarraute által is több ízben említett Virginia Woolfnál, illetve Proust-nál. A klasszikus lineáris idővonatkozás a szubjektív idődimenziót preferáló alkotásokban is elmosódik, csak itt nem a fenomenológiai hátterü,

\footnotetext{
${ }^{386}$ Heller Ágnes (2003). Filozófiai labdajátékok, Gond-Palatinus, Budapest, p. 256-258.

${ }^{387}$ Uo. p. 261.

${ }^{388}$ Uo. p. 270.

389 Deleuze-Parnet (2016). p. 17. „Mindaz, amit eltipornak és ártalmasnak nyilvánítanak, egy kép nélküli gondolkodáshoz tartozik - ilyen a nomádság, a háborús gépezet, minden leendés, természetellenes nász, rabul ejtés és lopás, minden „köztes” világ, ahogy a kisebbségi nyelvek vagy a nyelv dadogása is.”

390 Uo. p. 262.

${ }^{391}$ Kierkegaard, Sören (2008). Ismétlés L’Harmattan, ford. Gyenge Zoltán, Soós Anita

${ }^{392}$ Heller (2003). p. 263.
} 
megokolhatóságuktól függetlenül is eseménysorrendet mutató abszurd szemlélet szerint, hanem a tudatbensőben megélt egyéni időszemlélet külsődleges idővonatkozásoktól függetlenített világában.

A fent megidézett „kizökkent idő” tehát úgy értelmezhető, hogy szemben a lineáris temporalitásnak a mesélés és a karakterrel rendelkező szereplők összefüggésében megnyilvánuló értelemkonstituáló szerepével, amikor a meséléshez tudunk erkölcsi, érzelmi vagy ideológiai értelmezést társítani, ekkor a szereplők jelleme nem felépíthető, csak azt tudjuk, hogy mit tesznek, de sem az olvasó, sem maga a hős nem tudja, hogy miért, illetve a szereplők belső világának feltárulásához képest az események sorrendje másodlagos. Kizökken az idő, azaz a kronologikus sorrendiség racionalitása megszünik. A hagyományos mimetikus irodalmiságban az epikai münem esetében egyfajta kronologikus időrendiség volt jellemző, a külső idő volt fontos, ám az azutáni irodalomtörténeti szakaszokban, például a modernségben, ahogyan említettem, az idő egyre inkább megfoghatatlanná válik, belsővé módosul. Akár ha szubjektivizálódik, emlékekké, élményekké, az egyénen átszürődő valósággá válik mint Proustnál vagy Kafkánál, akár ha a jövőbe vagy egy elképzelt időbe helyeződik, mint Orwellnél vagy Goldingnál. Ezek a filozófiatörténeti és irodalomtörténeti folyamatok mind-mind előlegezik Sarraute időszemléletét.

Mi jellemzi Nathalie Sarraute műveinek idővonatkozásait? Külső vagy belső idő jelenik-e meg alkotásaiban? Ismét a Tropizmusokat és az esszéket alapul véve állítható, hogy mivel nincs szó ábrázolásról, mimézisről, ezért nincs szó idővonatkozások ábrázolásáról sem, hanem az időmozzanat esetében egyfajta megidézésnek lehetünk tanúi. Már esszéi előszavában hangsúlyos helyen említi, hogy a szépirodalomban „az idő többé nem a való élet

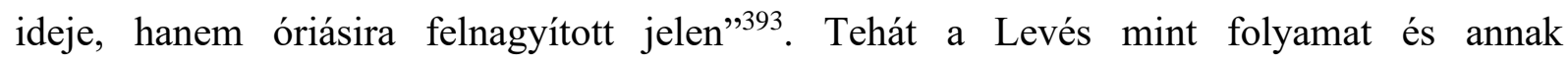
idővonatkozásai vannak szépprózájának középpontjában, de szövegeinek különlegessége, hogy a Levés-pillanatot mint az Örök-pillanat inkarnációját alkotja szöveggé. A szöveg-térben és a szereplő-foglalatokban megtestesülő öröklétet-halhatatlanságot írja tropizmussá. Mit is ért feltehetően Sarraute a „felnagyított jelen” fogalmán, és miért fontos számára, hogy ebben a különleges időben találják magukat müveinek olvasói?

Ha nincs cselekménysor, természetes, hogy nincs idővonatkozás, más megfogalmazás szerint a való élet időbeliségének és a fikció időbeliségének egybeesése fel sem merül

\footnotetext{
${ }^{393}$ Sarraute (1956). p. 9. „Le temps n'était plus celui de la vie réelle, mais celui d’un présent démesurément agrandi."
} 
lehetőségként, amennyiben a való élet ábrázolása nem motiválja a szerzőt. A bevezetőben említett külső és belső idő megjeleníthetősége abban az esetben valósítható meg csupán, ha a szöveg a való élet reprezentációját célozza, akár annak külsődleges (események) akár annak belső (lélektani) vonatkozásairól van szó. Ezektől azonban Sarraute távol tartja magát: az ő írói világa nem merül ki a külső vagy a belső valóság mozgásainak művé, alkotássá szerkesztésében, az események, gondolatok, érzelmek festésében. Ha maradnánk a narratológia logikájában, akkor a „mese” és a „szubjektum”394, a „történet” és az „elbeszélés”395 vagy az „elbeszélés” és a „diskurzus”396 egymásra hatásáról értekezhetnénk. Mindezek a narratológiai különbségtételek ugyanis a forrásukat a realitás és a fikció különválasztásában találják. Röviden megfogalmazható a kettős narratív időábrázolás elmélete, amely feltételezi a „normál” időbeliség meglétét, azaz a való élet belső és külső életidejét, valamint a fiktív szövegek reprezentációs sajátosságaként megjelenő megszerkesztett időbeliséget. Ám mindezen kettős időbeliség feltétele a mimetikus látásmód: Gérard Genette szerint az események sorrendje, a gyakoriság, az elbeszélés sebessége mindmind müvészi megszerkesztettségre utalnak a mimetikus elbeszélésben. Ugyanakkor Paul Ricoeur Temps et récit ${ }^{397}$ címü elméleti munkájában kifejti, hogy egy adott eseménysor a mimetikus eljárás során újraszerveződik vagy a muthos (konfiguráció) vagy a mimézis (refiguráció) ${ }^{398}$ segítségével. A ricoeur-i konfiguráció elmélete nem tér el nagyban a genette-i elbeszélői időtől. Ezek az időszerkezetek és a valós életidőkön „végrehajtott” alkotóiszerkesztői eljárások, amelyek arra hivatottak, hogy az olvasó át tudja élni az ekképpen rögzített eseménysort, képes legyen jobban megérteni saját viselkedését, és a környezetében élők jellemét, motivációit. Ezek az irodalmi fogalmak nem célozzák a mimetikus irodalmiság elméleti alapvetésének megrendítését, csupán újraformálják egyénre szabott terminológiájuk segítségével. A valóság és a fikció szétválasztása tehát nem is vezethet máshova, mint a mimetikus koncepció fenntartásához és a kettős narratív időbeliség fogalmainak újrafelfedezéséhez ${ }^{399}$.

\footnotetext{
394 Genette, Gérard (1983). Nouveau discours du récit, Paris, Seuil, 1983. p. 10. ; az orosz formalisták terminológiája fable, sujet

${ }^{395}$ Genette, Gérard (1972). Figures III., Paris, Seuil, p. 77. G. Genette saját terminológiája, amely utal a német elméletírókra - récit, histoire

396 Maingueneau, Dominique (1993). Éléments de linguistique pour le texte littéraire, Paris, Dunod, p. 124. ; Groupe $\mu$ (1982). Rhétorique générale, Éditions du Seuil p. 172. ; a szövegnyelvészetben jártas irodalomtudósok kedvelt terminológiája - récit, discours

${ }^{397}$ Ricoeur, Paul (1984). Temps et récit, Paris, Seuil

398 Uo. vol. II., p. 11-15.

${ }^{399}$ Erre a szemléletre jellemző például, hogy Gide Symphonie pastorale című regényének naplóbejegyzéseiben eltéréseket észleltek a tartalom és a dátumozás között, és erre felhívták a figyelmet.
} 
Ha a valós cselekmény reprezentációjának kérdéskörénél maradunk, akkor Paul Ricoeurrel mondhatjuk, hogy megfigyelhetjük a szereplő reprezentációját. ${ }^{400}$ Ez azt jelenti, hogy a fiktív alkotás ábrázol, de az elképzelt szereplő gondolatait, érzelmeit, nyelvhasználatát jeleníti meg. Dorrit Cohn ${ }^{401}$ hosszan elemzi a szereplő belső életének, lélektani valóságának reprezentációs módjait, a fiktív szereplők lelki valóságának ábrázolhatóságát. A témában elmélyedő német tudós, Käte Hamburger ${ }^{402}$ gondolatmenetét és terminológiáját alapul véve azt állítja, hogy a fiktív szereplők lelki életének reprezentációja az a sarokkő, amelynek segítségével valóság és fikció elkülöníthető. A szépirodalmi elbeszélés az egyetlen olyan lehetőség az emberiség számára, amely alkalmat kínál arra, hogy a megszólaló személyén kívüli, harmadik szereplő lelki valóságába bepillantást nyerhessünk. Ez az elgondolás azonban még mindig az arisztotelészi mimetikus logikán belül marad és fenntartja, hogy a fikció cselekménybe ágyazottan mutat be külső vagy belső történéseket.

Az illúziókeltés, a valószerüségre törekvő narráció kulcsszavai a történet és a szereplő is mindenképpen egyfajta lineáris időkezeléshez köthetők. A helyek váltakozása, az események logikája, a jellemek kibontakozása kronologikus rendben történik. A sarraute-i szereplőformálással összefüggő szövegépítkezés ugyanakkor időpillanatok egymás mellé helyezése, eklektikusan összefüzött eseménymorzsák, élet- és beszédhelyzetek, metonimikus felvillanások. Az alak szómögöttes tartalmaiban kitapintható benső állapotváltozások nem okolhatók meg, sőt, akár önmaguk ellentétébe is csaphatnak. Nem a regényirodalomban szokványos narratívával él, hanem inkább a festészet vagy a mozi szimultán, pointillista eszközeivel vagy zenei ellenpontokkal, változatokban való ismétlésekkel, sorozatok létrehozásával. Sarraute azzal indokolja az újfajta időhasználatot, hogy maga a folyamat legyen az érzelmileg, értelmileg, logikailag, erkölcsileg felépíthető, mindenképpen az olvasó tudatában realizálódon. Ahhoz, hogy a szövegvalóság a befogadó mentális szintjén épüljön fel, ahhoz minél inkább le kell építeni a szöveg tudatosan értelmezhető, ideológiai, erkölcsi célzatosságát, cselekményvezetését, és a kronologikus időt is. „Meg kellett törni a folyamatokat, hogy elérjem: az olvasó tudatában játszódjanak le, akár egy lassított filmfelvétel."

\footnotetext{
${ }^{400}$ Ricoeur (1984). p. 145.

${ }^{401}$ Cohn, Dorrit (1981). La transparence intérieure. Modes de représentation de la vie psychique dans le roman (traduit de l'anglais par Alain Bony), Paris, Seuil, 1981.

${ }^{402}$ U.o., p. 19-20.

Hamburger, Käte (1957). Die Logik der Dichtung, Stuttgart, Ernst Klett Verlag, 1957.

${ }^{403}$ Sarraute (1956). p. 9. „Il fallait aussi décomposer ces mouvements et les faire se déployer dans la conscience du lecteur à la manière d'un film au ralenti."
} 
Itt a Tropizmus filozófiai értelemben címü fejezetben már taglalt „másik valóság" fogalmát említeném ismét. A sarraute-i időfogalom szorosan köthető ehhez a filozófiai alapálláshoz, hogy a tropizmus ebben a másik valóságban zajlik le, abban értelmezhető. Ez az a ,felnagyított jelen”, amely valójában nem más, mint az író és a befogadó közös térideje, legyen ez akár a kierkegaard-i pillanat, közös pillanat, amely során megosztják a tropizmus jelenidejét.

„A regényíró számára kétféle valóság létezik.

Van egyszer az a valóság, amelyet mindenki lát maga körül, amelyet mindenki láthatna, ha alkalmunk nyílna szemtől szemben találkozni vele, ismert valóság, vagy legalábbis olyan valóság, amelyet könnyedén meg lehetne ismerni, egy valóság, amelyet vizsgáltak, tanulmányoztak már hosszú-hosszú ideje és közkézen forgó formákba öntve meg is próbáltak kifejezni, újraformálni ezredszer és még ezerszer utánozni.

Nem ez az a valóság, amelyhez a regényíró kapcsolódni szeretne. Számára ez csak a látszat, optikai csalódás.

A regényíró valósága az ismeretlen, a láthatatlan. Számára ez tűnik az elsődleges valóságnak, egyedül ezt látja; ez a valóság nem fejezhető ki az ismert, már alkalmazott formák segítségével. Új kifejezésmódra van szükség, hogy megmutatkozzon.

'A müalkotás' - mondta Paul Klee - 'nem a láthatót formázza meg. Hanem láthatóvá tesz'."404

A szerző tehát különbséget tesz a hétköznapi élet valósága, a látszatvalóság, a hazugság, a másolat, és egy másik realitás között, amely meghatározhatatlan, és az első valóság mögött, alatt húzódik meg. Azonosítja a mimézis fogalmát a cselekményvezetéssel, a valós életesemények rögzítésének szándékával, és mindazzal, ami együtt jár ezzel az „utánzással”: akár az életidő utánzásával is. Egyértelmű, hogy ha a valóság nem hiteles, akkor utánzata sem tételezhető hitelesként. Az ábrázolás, a szépirodalomban megjelenő idővonatkozás csak akkor lehet hiteles Sarraute szerint, ha a láthatatlan, ismeretlen oldalt fordítja felénk, teszi saját életidőnk egy pillanatában átélhetővé. A kifejezhetetlen kifejezése csakis abban a felnagyított jelenben képzelhető el számára, amely a leginkább képes felidézni a lélek ismeretlen mélyrétegeinek valóságát ${ }^{405}$.

${ }^{404}$ Sarraute, Nathalie (1996). "Roman et réalité" in Euvres complètes, p. 1644. "Il y a pour le romancier deux sortes de réalité. Il y a la réalité que tout le monde voit autour de soi, que chacun pourrait percevoir s'il se trouvait en face d'elle, une réalité connue, ou qu'il serait aisément possible de connaitre, une réalité qui a été prospectée, étudiée depuis longtemps, exprimée dans des formes elles-mêmes connues, reproduites mille fois et mille fois imitées. Ce n'est pas cette réalité-la qui est celle à laquelle s'attache le romancier. Elle n'est pour lui qu'une apparence, qu'un trompe-l'œil. La réalité pour le romancier, c'est l'inconnu, l'invisible. C'est ce qu'il lui semble être le premier, le seul à voir; ce qui ne se laisse pas exprimer par les formes connues et déjà utilisées. Mais ce qui exige pour se révéler un nouveau mode d'expression, de nouvelles formes. 'L'œuvre d'art' - disait Paul Klee - "ne restitue pas le visible. Elle rend visible.'"

Paul Klee: Alkotói vallomás. ford. Tillmann J.A. Elérhetö: http://www.c3.hu/ tillmann/index.html\# Letöltés ideje: 2020. 01. 13. "A müvészet nem a láthatót adja vissza, hanem láthatóvá tesz."

${ }^{405}$ Sarraute (1956). „Az idő nem a való élet ideje, hanem egyfajta mérhetetlenül felnagyított jelenidő.” p. 9. 
A sarraute-i prózapoétikában a cselekmény- vagy az időábrázolással kapcsolatos mimézis elutasítása szorosan összefüggés a szereplőábrázolás mimetikusságának felszámolásával. ${ }^{406}$ Nathalie Sarraute, bár nem tagadja az érzelmek, a benyomások, az emlékek létezését, elutasítja ezek közvetíthetőségét, közölhetőségét, és egyfajta rögzített jellem részeként való megjeleníthetőségét. A tropizmusoknak pontosan megragadhatatlanságukban kell, hogy verbalizálódjanak, és erre a legjobb módszer a szómögöttes mindenkori feltárása. „Kiderült, hogy leginkább hiteles benyomásainknak nincs egységes kiindulópontja; mi több, előzményei végtelenül egymásra rakódó rétegekben szerveződnek." ${ }^{407}$. Nem lehet bemutatni egy-egy érzést, hiszen akkor azt ismernünk kellene. Az idézet szintén az ábrázolhatóság és az idő összefüggésének problematikáját veti fel. A végtelen lehetőségekkel a végtelen idő lép be a mi véges és mérhető emberi időbeliségünkbe, ahogyan keresgélünk, és igyekszünk fogalmilag megragadni az idézetben említett végtelenül egymásra rakódó rétegek egynémelyikét. A felnagyított jelen pillanat gondolata talán ezt a hiányt igyekszik betölteni, ez az időtlenség, az idő nélküliség jelenideje.

Nathalie Sarraute arra törekszik müveiben, hogy szinte már-már kontextusukból kiragadva jelenítse meg a tropizmusokat. A cselekményvezetés időbelisége mindig azt feltételezi, hogy a múlt és a jövő linearitásának kontextusában jelenik meg az esemény. Amint ennek radikális elutasítása életbe lép, csupán a pillanat marad, az itt és most, az, amit felnagyított jelennek nevez. Ez magában hordozhatja éppen úgy a múlt, mint a jövő képeit, formáit, emlékeit, ígéreteit és sejtelmeit, mint az érzeteket, az érzelmeket, de ezek nem elmesélhetőségükben ábrázolódnak, hanem sejtetésükkel az írónő arra indítja az olvasót, hogy ő alkossa meg őket a tudatában.

Ennek az óriásira nagyitott jelennek a gondolata nem idegen a filozófiai gondolkodástól sem. Gilles Deleuze szerint az ember által egyetlen valóban felfogható és befogadható időbeliség van: a jelen idősíkja. Háromféle jelenidőt különböztet meg: „a nem mért idő, a mélység szétesett ideje, a felforgatásé; továbbá a sokszorozódó, mért jelenidők, a megvalósulás idősíkja"408. Ez a két idősík az úgynevezett Kronoszhoz kapcsolódnak. A harmadik típusú jelenidőt Deleuze az Aiôn részeként képzeli el, ez éppen olyan mély, széles és beláthatatlan, mint a Chronos első időtípusa, azonban ez a reprezentáció, az ábrázolás idősíkja. Esztétikai pillanat, amelynek nincs semmiféle kiterjedése, ugyanakkor magában

\footnotetext{
406 U.o., p. 145.

${ }^{407}$ Sarraute, Nathalie (1956). p. 16.

${ }^{408}$ Deleuze, Gilles, "Vingt-troisième série de l'Aiôn", in Logique du sens, Paris, Édition de Minuit, p. 196.
} 
hordozza mindazt a gazdagságot, amit csak a művészi módon megvalósuló valóság képes magában hordozni. Ez a deleuze-i gondolat az esztétikai pillanat időbeli dekontextualizálásáról egy korábbi művében már megjelenik, amelyet Proust Az eltünt idő nyomában elemzésének szentelt. ${ }^{409}$ Itt négy időstruktúráról beszél, amelyek mindegyikéhez egy-egy igazságfelfogást rendel. Az első az elveszett idő, a változás ideje, ami az emlékeket és a múltat hozza létre. Ez magával sodorja az üres szavakat és találkozásokat. A második az az idő, amit elveszítünk - ennek az idővonatkozásnak az igazsága azt a kérdést feszegeti, hogy miért élünk társasági életet, miért leszünk szerelmesek, ahelyett, hogy dolgoznánk vagy létrehoznánk 'A Mủalkotást'. A megtalált idő igazsága az elveszett idő ábrázolása által az öröklét képét idézi fel. A negyedik ,az abszolút értelemben vett, eredeti idő a valóságos öröklét, amely a müvészetben nyilvánul meg." ${ }^{410}$ A jeleket és az időbeliséget körbejáró deleuze-i elmélet és a sarraute-i időfogalom között az az összefüggés, hogy mindketten a művészi megformálás jelenidejét összefüggésbe hozzák az öröknek, végtelennek tételezett pillanattal. Az újfajta művészi megjelenítés új idővonatkozást feltételez, amelynek lényege a művészi megformálás örök jelenben való elhelyezése.

Hogyan realizálódik ez az időszemlélet a stílus szintjén Nathalie Sarraute fikciós müveiben? Első műve, a Tropizmusok ${ }^{411}$ szinte egészében az úgynevezett imparfait múlt időben íródott. A franciában két múlt időt ismerünk a beszélt nyelvben (eltekintve az időegyeztetésekkor használt egyéb, funkcionális múlt időktől), a passé simple pedig hagyományosan a mesélés írott változatának kötelező múlt ideje. A passé composét, amelynek szerepe, hogy a múltban történt eseménysor egyes történéseit visszaadja, és az imparfait, amely érzékelteti a múltbeli eseménysor hangulatát, szereplőjének lelkiállapotát, valaminek a milyenségét. Az imparfait az az idősík, amely „nem elégséges ahhoz, hogy önmagában képes legyen az események sorrendiségének megteremtésére" ${ }^{\$ 12}$. Nyelvészeti termiusokkal megfogalmazva: az imparfait csak úgy tud müködni a szövegben, ha más igeidők viszonylatában jelenik meg, például a passé composé (irodalmi művek esetében a passé simple) viszonylatában, amellyel referenciális keretbe foglalja a teljes eseménysor időbeliségét. Az imparfait folyamatos és kizárólagos használatával Sarraute arra törekszik,

\footnotetext{
${ }^{409}$ Deleuze, Gilles (1964). Proust et les signes, Paris, Presses Universitaire de France, 1964.

${ }^{410}$ U.o. p. 26. quatre structure du temps, chacune ayant sa vérité : 1. temps perdu : temps qui passe, altérant les êtres et anéantissant ce qui fut 2. le temps qu'on perd (pourquoi faut-il perdre son temps, être mondain, être amoureux, plutôt que de travailler et de faire œuvre d'art ?) 3. le temps retrouvé : un temps qu'on retrouve au sein du temps perdu : nous donne une image de l'éternité 4. "un temps originel absolu, véritable éternité qui s'affirme dans l'art"

${ }^{411}$ Sarraute, Nathalie (1957). Tropismes, Paris, Éditions de Minuit

${ }^{412}$ Herschberg-Pierrot, Anne (1993). La stylistique de la prose, Paris, Belin, 1993, p. 84.
} 
hogy kontextusából kiragadja a megörökíteni kívánt tropizmust, ellehetetlenítse azt a referenciális hálót, amelyben, a passé simple és az imparfait igealakok egymáshoz való viszonyában kibontakozhatna valamiféle történés. Így az imparfait (tökéletlen) befejezetlenséget sugall, és önmagában állva, önmagáért, önmagában megjelenítve még inkább lecsupaszítja a tropizmust, jeltárgy nélküli jellé formálja.

Az igéknek így nincs eseményi hátterük, hiányzik a passé simple, a történéssor, a múlt idő valamely formájához való ragaszkodás ugyanakkor a fikciós irodalom elsődleges jele, jelzése. ${ }^{413}$ Olyan, akárcsak egy ajtó a fikció világába ${ }^{414}$. A szerző első könyvében a fikció világában kíván maradni, az elbeszélő, epikus szépirodalom vonatkozásában képes elképzelni a művét, bár ő maga kritikával illeti a többi múlt idő használatát. Ezek az imparfait alakok segítségével elbeszélt tropizmusok éppen ezért amolyan kimerevített, de múltbeli, az epikusság fenntartását szolgáló pillanatok, „sárba ragadt” helyzetek, szereplők, akik mégis mintha mindnyájan a „kard élén táncolnának”. Mintha minden pillanat azzal fenyegetne, hogy valami elfojtott indulat, lappangó tragédia törne ki, kerülne a felszínre ${ }^{415}$.

Az imparfait alakok továbbá akár úgy is értelmezhetőek, mint a „,szakítás igeideje”416. Ennek az igeidőnek ilyen típusú használata a francia irodalomban 1850 után vált jellegzetessé, és nem más, mint a háttérinformációk megfogalmazására szolgáló imparfait kiterjesztése a teljes szövegvilágra. Abban tér el a hagyományos imparfait alakoktól, amelyek a passé simple viszonylatában jelentek meg, hogy önmagában képesek az elbeszélés idöbeliségének meghatározására azzal a különbséggel, hogy egyfajta „totális látványt, optikát” kíván beemelni a szövegbe. ${ }^{417} \mathrm{Ez}$ a múlt idejü igeidők eredeti funkciójával szakító imparfait akár a klasszikus mimetikus reprezentációval való szakítás metaforája is lehet a tropizmus esetében. Ez az imparfait az, aminek következtében azt érezhetjük, hogy nem „történik” valami, hanem minden egyes megjelenített pillanat mögött minidrámák húzódnak, amelyek bármelyik pillanatban kirobbanhatnak.

Az imparfait elsődlegessége a szereplő vonatkozásában azt jelenti, hogy felerősödik a szöveg leíró jellege, a történés helyett az alakok szómögöttes tartalmaira, a titkos háttérmotívumokra tesz a szerző dadogó módban, újra és újra nekifutva utalásokat. Az olvasóhoz is közelebb hozza az elbeszélést, hiszen a csupán lelki érzékekkel kitapintható

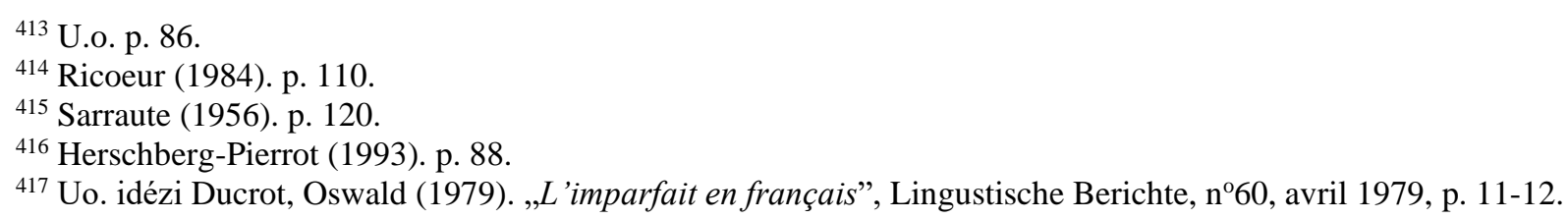


mozdulatsor a szövegvilágból az olvasó világába helyeződik át, ott nyer értelmet, ott jön létre, tudatosan nem az írott szövegvilágban. Az imparfait-ben íródó tropizmus képes arra, hogy hozzásegítse az olvasót a szöveg megérkezéséhez, a tropizmusnak az ő személyes életében való megéléséhez, „feltámasztásához”, és ezzel egyesíti, egzisztenciális közelségbe hozza a szöveget az olvasóval.

„Az olvasó szüntelenül megfeszül, éberen figyel, mintha ő lenne az, akihez szólnak a szavak, mozgósítja valamennyi védekező mechanizmusát, minden intuitív képességét, az emlékezetét, érvelőés ítélőképességét: fülét lesunyó veszélyt észlel a lágyan egymást követő mondatfüzérek takarásában, halálos hatások sejtelmét rejti rossz előérzete, figyel: egy-egy gyengédséget hordozó kifejezés akár finom mérget is csepegtethet." 418

Magának a szövegnek nem kell tartalmaznia semmiféle ,jeltárgyat”, amely felkelti az intuíciót, az ítélőképességet vagy emlékeket idéz. Nem tesz mást, mint beúsztat az olvasói optika elé egy megmerevedett helyzetet, nyelvileg jelzi különállását, elszakadását, akár az imparfait alakok segítségével, és a továbbiakban az olvasó mentális müködésének feladata, hogy önmagán, önmagában elvégezze azt a munkát, amit az megítélés, az emlékek felidézése vagy az intuíciók felélesztése jelent. A tropizmusok megmerevedett állapotokat, kimerevített képeket, megkövült szituációkat mutatnak fel a szómögöttes segítségével. A szómögöttes adott élethelyzetekre fókuszál, azokban nyer életet, verbalizálja azt a sokrétü valóságot, amely egy-egy pillanat mögött, alatt rejtve létezik. Ezeket a láthatatlan rétegeket, végtelenül a mélybe húzódó lépcsősorokat, amelyek egy-egy szavunk, tettünk mögöttesei, Sarraute gyakran jelenidőben fejezi ki.

Összefoglalóan a mimetikus reprezentáció elkerülésére való törekvés magával von egyfajta sajátos hozzáállást a fiktív szövegek igeidőhasználatában. Az elméleti szövegekben óriásira nagyított jelenidőnek nevezett időkoncepció a Tropizmusokban az imparfait alakok túlburjánzó használatában, illetve a teljes rugalmasságot biztosító jelenidő időnkénti előfordulásában valósul meg, attól függően, hogy az adott Sarraute-próza a tropizmust vagy a szómögöttest helyezi-e éppen előtérbe.

XXII.

Parfois, quand ils ne le voyaient pas, il pouvait tout doucement, pour essayer de trouver autour de lui quelque chose de chaud, de vivant, passer la main le long de la

XXII.

Alkalomadtán, mikor nem látták, észrevétlen megkísérelt maga körül valami élettel teli melegségre lelni - végighúzta az ujjait az ebédlőszekrény fadongáin... nem

\footnotetext{
${ }^{418}$ Sarraute, Nathalie, (1956). p. 120-121. „Le lecteur, sans cesse tendu, aux aguets, comme s'il était à la place de celui à qui les paroles s'adressent, mobilise tous ses instincts de défense, tous ses dons d'intuition, sa mémoire, ses facultés de jugement et de raisonnement: un danger se dissimule dans ces phrases douceâtres, des impulsions meurtrières s'insinuent dans l'inquiétude affectueuse, une expression de tendresse distille tout à coup un subtil venin"
} 
colonne du buffet... ils ne le verraient pas ou peut-être ils croiraient qu'il se bornait manie très répandue et après tout inoffensive - à conjurer le sort en « touchant du bois" .

S'il sentait derrière lui leur regard l'observant, comme le malfaiteur, dans les films drôles, qui, sentant dans son dos le regard de l'agent, achève son geste nonchalamment, lui donne une apparence désinvolte et naïve, il tapotait, pour bien les rassurer, avec trois doigts de la main droite, trois fois trois, le vrai geste efficace pour conjurer. C'est qu'ils le surveillaient de plus près, depuis qu'il avait été surpris dans sa chambre, lisant la Bible.

Les objets se méfiaient aussi beaucoup de lui et depuis très longtemps déjà, depuis que tout petit il les avait sollicités, qu'il avait essayé de se raccrocher à eux, de venir se coller à eux, de se réchauffer, ils avaient refusé de "marcher », de devenir ce qu'il voulait faire d'eux, " de poétiques souvenirs d'enfance ». Ils étaient bien matés, les objets, bien dressés, ils avaient le visage effacé, anonyme, des serviteurs stylés ; ils connaissaient leur rôle et refusaient de lui répondre, de crainte, sans doute, de se voir donner congé.

Mais à part, très rarement, ce petit geste timide, il ne se permettait vraiment rien. Il avait réussi peu à peu à maîtriser toutes ses manies stupides, il en avait même moins maintenant qu'il n'était normalement toléré ; il ne collectionnait même pas - ce que, au vu de tous, les gens normaux faisaient - les timbres-poste. Il ne s'arrêtait jamais au milieu de la rue pour regarder - comme autrefois, à la promenade, quand sa bonne, mais allons donc ! allons ! le tirait, - il passait vite et n'entravait jamais la circulation sur la chaussée ; il passait devant les objets, même les plus accueillants, même les plus animés, sans leur jeter un regard de connivence.

En somme, ceux mêmes de ses amis, de ses parents, qui étaient férus de psychiatrie ne pouvaient rien lui reprocher, sinon, peut- vennék észre, vagy ha mégis, akkor talán azt hihetnék, hogy mozdulata - akár egy ártalmatlan, ám bevett hóbort -, csupán azt célozza, hogy átírja a sorsot, lekopogja.

Ha a hátát pörkölte árgus szemük figyelmes pislogása, akkor, mint a gonosztevő a tréfás filmekben, aki maga mögött észleli a felügyelö tekintetét, még fesztelenül befejezi szándékolatlannak és önkéntelennek mímelt mozdulatát, úgy kezdett dobolni az ujjaival, hogy nyugalmat árasszon, a jobb keze három ujjával, háromszor hármat, csak hogy hatékony legyen a babonajáték. Mindez azért eshetett meg, mert egyre közelebbröl követték, mióta rajtakapták, hogy a szobájában a Bibliát olvassa.

A tárgyak is rossz sejtelemmel viseltettek iránta, azóta, hogy gyermekként beléjük csimpaszkodott, valósággal rájuk tapadt, hogy felmelegítsék, s átjárja az élet; vonakodtak azzá válni, aminek ő készült látni őket, ,,a gyermekkor költői emlékeivé”. Rendreutasították és megzabolázták őket, arcukat eltörölték, névtelen, jól kiképzett háziszolgákká lettek; belátták, mi a dolguk, s nem voltak hajlandóak többé őt válaszra sem méltatni, kétségtelenül féltek, hogy megválnak tőlük.

Eltekintve azonban e ritkán előforduló tétova mozdulattól, tényleg semmit nem engedett meg magának. Fokozatosan sikerült úrrá lennie őrült hóbortjain, sőt, most már még annál is kevesebb volt neki, mint amennyit normális esetben elviseltek; nem gyüjtötte még a postabélyegeket sem, noha ez az épelméjüek mindenki szeme láttára felvállalt szokása is lehetett volna. Soha meg nem állt mostantól az utca közepén, hogy elbambuljon - mint rég, sétakor, amikor a kísérő személyzet, gyerünk! uzsgyi, csak! húzta-vonta -, hanem folytatta útját, és nem tartotta fel a forgalmat; elhaladt az útjába eső tárgyak előtt, még a legcsábítóbbak, a leginkább élettel telítettek előtt is, anélkül, hogy akár egyetlen cinkos pillantást vetett volna rájuk.

Mindent összevetve, még azok közül a 
être, devant ce manque chez lui d'inoffensives et délassantes lubies, devant son conformisme par trop obéissant, une légère tendance à l'asthénie.

Mais ils toléraient cela ; c'était, tout bien considéré, moins dangereux, moins indécent.

De temps à autre seulement, quand il était trop fatigué, sur leur conseil, il se permettait de partir seul faire un petit voyage. Et làbas, quand il se promenait à la tombée du jour, dans les ruelles recueillies sous la neige, pleines de douce indulgence, il frôlait de ses mains les briques rouges et blanches des maisons et, se collant au mur, de biais, craignant d'être indiscret, il regardait à travers une vitre claire, dans une chambre au rez-de-chaussée où l'on avait posé devant la fenêtre des pots de plantes vertes sur des soucoupes de porcelaine, et d'où, chauds, pleins, lourds d'une mystérieuse densité, des objets lui jetaient une parcelle - à lui aussi, bien qu'il fût inconnu et étranger - de leur rayonnement; où un coin de table, la porte d'un buffet, la paille d'une chaise sortaient de la pénombre et consentaient à devenir pour lui, miséricordieusement pour lui aussi, puisqu'il se tenait là et attendait, un petit morceau de son enfance. barátai vagy rokonai közül is, akik bele lettek volna habarodva a pszichiátriába, közülük sem tehetett neki senki sem szemrehányást, hacsak nem az ártalmatlan, bár önerősítő, majd elmaradó hóbortjaiért vagy az imádott konformizmusáért $\mathrm{s}$ egyfajta aszténiára való enyhe hajlamáért.

Ám ők mindezt jól türték; mindez, ha jól megfontoljuk, kevéssé veszélyes, még kevésbé szemérmetlen.

Csupán időről időre, amikor már túlságosan kifáradt, tanácsukat szem előtt tartva engedélyezett magának egy-egy rövidke magányos utazást. És ottan naplemente körül sétára indult a hó alatt áhítatosan nyújtózó, szelíd bánattal teli utcákat bejárva, kezeivel végigsimította a házak fehér és piros kőtégláit, szinte a falhoz tapadva, oldalvást, tartva attól, hogy túlságosan is indiszkrét lesz, bekandított egy-egy kivilágított ablaküvegen a földszinti szobácskákba, ahol valaki az ablak elé élénken zöldellö szobanövényeket ültetett, cserépkosárba, porcelán csészealjakon, s ahol azok meleg valójukból kilépve egyfajta titokzatos buja burjánzásban nehezülnek el, mindenfelé küldve fénylö sugaruk - az őszámára is, bár ismeretlen volt és idegen -; vagy egy asztalsarok, egy tálalószekrényajtó, egy félárnyékból világló szék gyékényülökéje beletörődhetett abba, hogy könyörületessége révén, neki, igen az ö számára, mivel türelmesen ott áll és vár, megidézze üde gyerekkorát.

A XXII. tropizmus középpontjában álló, ezúttal hímnemű $i l$ szereplő-alak a felütésben a tárgyak érintésével, a tárgyak jelenlétében megélt csendes szemlélődésével van jelen. A szövegegységben ugyanúgy az imparfait használata jellemző, mint a Tropizmusok többi szövegében. Ugyanakkor itt azért van nagyobb jelentősége az imparfait visszatérö használatának, mert a középpontban az emlékezés, a múlttal való ambivalens viszony áll. Ezen azt értem, hogy a múltunk keresztjei, sokkjai nyomasztanak, a múltból ki kell lábalnunk, ugyanakkor a múlt épít, felemel, büszkeséggel tölt el és táplál minket mint hagyomány és kötődés. Ez a fajta amivalencia a szekvencia utalásrendszerében egyértelműen tetten érhető, a 
tárgyak érintésének pulzálásában jelenidejüsíthető, ez a tropizmus elevene. A szövegrész Proust-rezonanciája azt a képzetet kelti, hogy a szereplö-alaknak a gyermekkorában őt körülvevő tárgyakkal való intimitás emlékérzete átható megnyugvást hozhat. Ennek a tropizmikus szómögöttes mozgássornak a szövegen belül ellenlábasai vannak. A szereplöalakot körülvevő személyek, akik elöl rejtegeti még maga számára sem szavakba foglalható, emlékeket és élményeket rejtő érzet-kötegeit. Magára hagyatottsága ebben a tropizmusáramlásban ugyanakkor sarkított, hiszen maguk a tárgyak is „rossz sejtelemmel viseltetnek iránta”. Sőt, még belső konfliktusára is fény derül, hiszen önmaga elött is igyekszik leplezni tropizmikus folyamatait, olvassa a Bibliát, bélyeggyüjtést tervez. Talán még az is jobb, hogy hóbortosnak tartsanak, mint hogy a megélt tropizmus-érzet másik valósága napvilágra kerüljön. A tropizmikus síkon lejátszódó minidrámára a későbbiekben az a megoldás kínálkozik, hogy a szereplö-alak elutazik, ezáltal nézőpontot vált és immár képes arra, hogy higgyen benne: valamely tárgyi ethosszal tud ilyen módon valamiféle emlékekben feloldódó egységet alkotni. „(...) egy asztalsarok, egy tálalószekrény-ajtó, egy félárnyékból világló szék gyékényülökéje beletörődhetett abba, hogy könyörületessége révén, neki, igen az ő számára, mivel türelmesen ott áll és vár, megidézze üde gyerekkorát." A szövegzárlat megszemélyesítések révén éri el, hogy enyhén ironikus áthallásban, de a prousti mintára létrejöjjön a tárgy-intimitás révén az emlékezés.

\begin{tabular}{|c|c|}
\hline $\begin{array}{c}\text { A tropizmus elvene, az emlékezés } \\
\text { ambivalenciája }\end{array}$ & $\begin{array}{c}\text { Társadalmilag elfogadható } \\
\text { viselkedésformák }\end{array}$ \\
\hline $\begin{array}{l}\text { megkísérelt maga körül valami élettel teli } \\
\text { melegségre lelni - végighúzta az ujjait az } \\
\text { ebédlőszekrény fadongáin... } \\
\text { gyermekként beléjük (a tárgyakba) } \\
\text { csimpaszkodott, valósággal rájuk tapadt, } \\
\text { hogy felmelegítsék, s átjárja az élet } \\
\text { e ritkán előforduló tétova mozdulat } \\
\text { kezeivel végigsimította a házak fehér és } \\
\text { piros kőtégláit, szinte a falhoz tapadva, } \\
\text { oldalvást }\end{array}$ & $\begin{array}{l}\text { átírja a sorsot, lekopogja } \\
\text { árgus szemük figyelmes pislogása } \\
\text { babonajáték } \\
\text { a Bibliát olvassa } \\
\text { nem gyüjtötte még a postabélyegeket sem } \\
\text { tanácsukat szem előtt tartva engedélyezett } \\
\text { magának egy-egy rövidke magányos utazást }\end{array}$ \\
\hline
\end{tabular}


Az imparfaitra itt különös hangsúly helyeződik, szerepe ezért még nagyobb, mint máshol, hiszen az idősíkok felidézése változatos igeidőhasználatot szükségeltetne, s mégis az imparfait adja meg a XXII. rész ritmusát. Összesen rajta kívül két plus que parfait és egy passé simple alak szerepel. Ugyanakkor az imparfait igealakok ritmikus visszatérése, iterativitása biztosítja, hogy a cselekmény elmosódik, a szereplö-alak tropizmikus mozgássorára helyeződik a hangsúly, ami valamiféle meghatározatlanságot, sőt, időtlenséget kölcsönöz a szövegnek. ${ }^{419}$ Azt célozza, hogy kiemelje a szereplö-alakot is, valamit az olvasót is szubjektivitásából és az általa keltett ritmikus hullámzás mozgássorába helyezve interszubjektív tér-időt hozzon létre ${ }^{420}$.

A szöveg középpontjában ugyanis nem az áll, hogy mik is azok az emlékfoszlányok, amelyek visszatérhetnek a tudatba, amint megkezdődik végre az emlékezés, hanem az a folyamat, amelynek révén a tropizmust megélő személy képes függetleníteni saját, ki nem mondott tartalmak hullámzásaként megélt, sajátos belső világát, valamint az abból fakadó viselkedésformákat a környezete által és önmaga által látszólag elvártaktól. A szövegrészben nincs párbeszéd, nincsenek szavak. Mind a tropizmust átélője, mind a tropizmus ellenlábasai nonverbális magatartásformákkal közelednek egymáshoz és azokból vonnak le következtetéseket. A tárgyak azonban megelevenednek: ironikus hatást kelt, hogy pont a tárgyak elevenségérzetének élménye ellen harcol a szereplő-alak, s Sarraute mégis szüntelenül emberekre jellemző igékkel látja el a fel-felbukkanó dolgokat.

\section{Nathalie Sarraute további epikus müveinek szereplöi}

A klasszikus regényhős karakteréről akár valós személyekre is asszociálhatunk. Az Új Regényben a szereplőnek már nincs ilyen értelemben teste-lelke. Nem pozitív vagy negatív lény, nem nyeri el a szimpátiánkat vagy az antipátiánkat, sőt, gyakran nem is antropomorf szereplők, hanem szavak, könyvek, fogalmak, molekulák. Nathalie Sarraute szereplői tropizmus-foglalatok, olyan erők, olyan humán érzelmi vagy érzéki töltetek, amelyek szavakra nem válthatók vagy nem testesülhetnek meg. Arctalanított tropizmus-hordozók, nincs személyes vetületük és nem lehet hozzájuk jelentést társítani, a velük való kapcsolatfelvétel lényege a már-már fizikai érzetekben átélhető azonosulás és nem a

\footnotetext{
419 Bénard, Johanne (1980). "Silence, tropisme et stéréotype chez Nathalie Sarraute" Annuaire Théâtral Elérhető : https://id.erudit.org/iderudit/041523ar, Letöltés ideje : 2020. 01. 15.

${ }^{420}$ Lee, Mark (1996). "Tropismes : le réel comme rythme de l'histoire, Le rythme : littérature, cinéma, traduction", Études littéraires Volume 29, numéro 1, été 1996. Elérhető: https://id.erudit.org/iderudit/501143ar, Letöltés ideje: 2020. 01. 13.
} 
találkozásból való tanulás, a jellemek magunkra nézve való értelmezése. Az alakok megjelenítése ilyen értelemben Sarraute-nál érzékeny, gyakran részletező jellegü, mégis az vehető észre, hogy idegenek a világ számára, izolálódnak.

A nyelvi jelet motiválatlan, önkényes volta határozza meg, de az önkényesség szintje változó jelenként, a nyelven belül is, és más szemiológiai rendszerekben is. Például a szereplő nevének és a szereplőnek a kapcsolata - jelölöje lehet: tulajdonnév, köznév, különféle helyettesítő szavak, szófajok vagy leírások, amelyek változó jellegét biztosítják és azoknak az információknak az összessége, amelyekre mindez utal (a szereplö jelöltje) - ez a kapcsolat nagyrészt motivált. Valamilyen külső, konnotatív okból választják az írók az adott szereplő nevét. $^{421}$

Nem véletlen, hogy a Sartre által bevezetett ,anti-roman” fogalom a Portrait d'un inconnu előszavában bukkan fel először. Írásában számos irodalmi-művészeti utalást tesz, például: a 40-es évek egyes alkotói „regényeket írnak regényekről, amelyek végül is nem íródnak meg”422. A követés, a megfigyelés, a keresés gesztusa miatt, amely az apa és a lánya életébe betekintő elbeszélő szándékaira összepontosít, Sartre krimihez ${ }^{423}$ hasonlítja a művet. Felhívja a figyelmet a közhelyek szerepére, amelyek bevezetik a regényvilágba az emberek között használt hétköznapi nyelvezet mindenki számára érthető valóságát, közös, bár a lényeg szempontjából csak formális platformot teremtve ezzel. Ha szubjektív szempontból szeretnénk felépíteni értelmezésünket a regényvilágból, akkor a sztereotípiák miatt az objektivitás falába ütközünk, és fordítva, ha valamiféle objektív jelentésadás a célunk, akkor túl szubjektívnek fogjuk érezni a szöveget ${ }^{424}$.

Nathalie Sarraute a közhely fogalmának meglehetősen tág definíciót adott $A$ gyanakvás kora címü esszéjének előszavában.

„A folyamatos oda-vissza játék a tropizmusok és a látszatok világa között, és a közhelyek, amelyek mindebből külsőségként érzékelhetőek: a beszélgetéseink, a jellem, amellyel látszólag rendelkezünk, a személyiség, akinek egymás szemében tününk, az érzelmek fogalmai, amelyekről csak hisszük, hogy valóban érezzük őket és hogy másoknál is ezeket tapasztaljuk, és a látszólagos dráma, megszerkesztett cselekmény, ami nem más, mint konvencionális váz, amelyet az életre alkalmazunk." ${ }^{\$ 25}$

\footnotetext{
${ }^{421}$ Hamon (1972).

${ }^{422}$ Sartre, Jean-Paul (1956). "Préface" in Sarraute, Nathalie, Portrait d'un inconnu, Gallimard, p. 9.,,écrire des le roman d'un roman qui ne se fait pas"

${ }^{423}$ Sartre (1956). p. 10. roman policier — Sabine Raffy értelmezésében [Raffy (2002).] szintén megjelenik a tropizmust átélő személyek, a tropizmus hordozói és a tropizmus ellenlábasai közötti konfliktus, az üldöztetés mozzanata.

${ }^{424}$ U.o. p. 11.

${ }^{425}$ Sarraute, Nathalie (1956). L'ère du soupçon, p. 10.,[...] ce jeu constant entre eux [les tropismes] et ces apparences, ces lieux communs sur lesquels ils débouchent au-dehors : nos conversations, le caractère que nous paraissons avoir, ces personnages que nous sommes les uns aux yeux des autres, les sentiments convenus que nous croyons éprouver et ceux que nous décelons chez autrui, et cette action dramatique superficielle, constituée de l'intrigue, qui n'est qu'une grille conventionnelle que nous appliquons sur la vie".
} 
A közhelyek szintjén jön létre a Portrait-beli látszatkonfliktus: az elvárt klasszikus regényelemek ütköznek a ki nem mondott mélyrétegekkel. Flaubert is érdeklődött a klisék iránt, gyüjtötte is a közhelyes nyelvi elemeket ${ }^{426}$. Ugyanakkor számára ez a nyelvi réteg elítélendő volt, mert volt mögötte valódi értelem, pontosabban éppen az egyéni gondolkodást hiányolta belőle. Sarraute-nál a közhelyek szerepe más. Itt a kommunikáció látszatvalóságát jelenítik meg az emberi érintkezésnek azt a szintjét, amely mindig új és új tartalmakkal telik meg, hiszen nélkülözhetetlen a ki nem mondott valóságokhoz való hozzáférés szempontjából. „A szavak, ha akarjuk, ha nem, jelentenek valamit (...). Jelentésként érzékeljük őket, függenek az általunk nekik tulajdonított jelentéstől (...)." ${ }^{427}$ Nem tud felállni valamiféle ellentét az ember külső-belső valósága ${ }^{428}$ között, erre érez rá Sartre is (objektivitásszubjektivitás fogalmaival), mert nem az az író célja, hogy a semmitmondó külsőségeket, a hétköznapok sztereotípiáit állítsa szembe a belső lelki élet gazdagságával. Hanem a megismerés szintje, a hétköznapi, látszatokból és közhelyekből felépülő valóság van, egyszerüen létezik és elkerülhetetlen, de utal arra a nonverbális szintre, amelyhez viszont a hozzáférés csak rajta keresztül valósulhat meg. „A közhely egyfajta tünetként jelentkezik, amely egyszerre elrejti és feltárja a beszélő alany igazságát." ${ }^{29}$

„Nathalie Sarraute a hiteltelenség fala elé állítja az olvasót; mindenütt ezt láttatja velünk." ${ }^{430}$ Továbbra is Sartre szavaival élve Sarraute a közhelyek mögött az ember belső világának egyfajta „protoplazmikus vízióját adja”431. Azaz „távolítsátok el a közhely odagördített kövét, és amit találni fogtok: nyálka, ragacs, nyák, amőbaként elnyúló hezitáló mozdulatok." ${ }^{432}$ Ez esztétikai értelemben azt jelenti, hogy Sarraute kiforgatja sarkaiból a hagyományos, lélektani elemzésre lehetőséget adó szereplőábrázolást, bizonyos értelemben anti-lélektani ${ }^{433}$ irányultságú, nem törekszik arra, hogy az olvasót kegyelmi állapotba hozza,

\footnotetext{
${ }^{426}$ Gustave Flaubert (1999). Bouvard et Pécuchet, Livre de poche

427 „Les mots, quoi qu'on veuille, signifient [...]. Ils sont perçus comme signification et dépendent d'elle forcément [...]. Nous ne cessons de les remplir." Sarraute, Nathalie (1986). Flaubert le précurseur, Paris, Gallimard, p. 69.

${ }^{428}$ réalité extérieur-intérieur (Sarraute), objectivité-subjectivité (Sartre)

${ }^{429}$ Adert, Laurent (1996). Les mots des autres. Flaubert, Sarraute, Pinget, Presses du Septentrion, Villeneuve d'Ascap, p. 186. „Le lieu commun fonctionne en somme comme un symptôme qui révèle et cache à la fois la vérité du sujet."

${ }^{430}$ Sartre (1956). Préface. p. 12. „Nathalie Sarraute nous fait voir le mur de l'inauthentique; elle nous le fait voir partout."

${ }^{431}$ U.o. p. 13. „vision protoplasmique”. Protoplazmikus: sejt élő anyaga; átlátszó, kocsonyás állomány

${ }^{432}$ U.o. „otez la pierre du lieu commun, vous trouverez des coulées, des baves, des mucus, des mouvements hésitants, amiboides."

433 Tison-Braun (1971). p. 14. anti-psychologie, regard observateur, vision pessimiste : les moments de grâce sont rares (amour, création)
} 
„biztosítsa” számára a jól megérdemelt katarzist. Ezekben a korai regényeiben, az elszigetelt hősök világában látszólag még mintha arcot adna számukra, mintha belegabalyodna a jellem, a név, a viselkedésmód, a kapcsolatrendszer hálójába. ${ }^{434}$ Azonban a szómögöttes tartalmak feltárása és a sarraute-i írástechnika kiforrott jelenléte miatt már itt is észrevehető, hogy nem elhallgatott, a tettek mögött deklaráltan ott rejtező néma gondolatok ${ }^{435}$ feltárására törekszik, amelyeket a karakterek tudatosan csupán belső monológjaik formájában engednek szabadon, hanem már itt is érezhető, hogy a szómögöttes éppen a születőben lévő érzet, az érzelem és a gondolat és a szó határmezsgyéje.

Szereplői éppen ezért a Tropizmusokat követő alkotásokban is arctalanított tropizmusfoglalatok, ahogyan Sartre írja: „Nathalie Sarraute könyvében ne keressünk mindazt, amit nem akar nekünk írónként 'nyújtani' - az ember az írónő számára nem a jelleme, nem a története vagy szokásrendje: amit kapunk, az az általános és a személyes közötti lágy és folyamatos áramlás." ${ }^{436}$ A jelentés nélküli személytelenség. Ahogyan Deleuze fogalmaz:

„Titkod arcodra van írva, ott van mindig a tekintetedben. Hagyd el az arcot! Tanulj meg szeretni emlékek, vágykép és értelmezés nélkül, anélkül, hogy pontot tennél, összegeznél! Hogy már csak áramlások legyenek, melyek hol kiapadnak, megfagynak, kiöntenek, hol összefolynak, vagy épp szétválnak." $" 37$

Sarraute minden prózai müvében újra és újra ugyanazt a stílusformát bontja ki, mutatja meg más nézöpontból. Keres valamit, amit úgy közelít, hogy ismétli ugyanazt. Ezt nevezi kérődzésnek ${ }^{438}$. A tropizmusok minidrámái abból adódnak, hogy a látszathoz, illetve a ki nem mondott szó szintjéhez kapcsolódó szereplők ellentmondásba kerülnek. Az elbeszélő 439 gyakran azt a hangot képviseli, aki aktualizálja a tropizmust, közvetíti a szómögöttes beszédfoszlányokat. A felettes-elbeszélö ${ }^{440}$, aki „kontrollál, felügyel, a látszatot, a köznyelvi fogalomhasználatot képviseli, felettes-én." ${ }^{441}$ Gaetan Brulotte ${ }^{442}$ felhívja a figyelmet arra, hogy ez a fajta kettősség megjelenik a szövegformálás szintjén is, mert a narráció szinte mindig egyfajta dialogikusságot, kettősséget mutat: A Portrait d'un inconnu címü regényben például az apja-lánya viszonyban, a Planetáriumban Berthe és Alain viszonyában, a Martereau-ban a nagybácsi és a nagynéni viszonyában. Brulotte még a Fruit d'or-ban is

\footnotetext{
434 Uo. p. 15.

${ }^{435}$ Uo. pensée muette

${ }^{436}$ Sartre (1956). Préface. p. 14. „Ainsi ne faut-il pas chercher dans le livre de Nathalie Sarraute ce qu'elle ne veut pas nous donner ; un homme, pour elle, ce n'est pas un caractère, ni d'abord une historie ni même un réseau d'habitudes: c'est le va-et-vient incessant et mou entre le particulier et le général".

${ }^{437}$ Deleuze-Parnet (2016). p. 43.

438 rumination

439 Sartre (1956). Préface narrant

${ }^{440}$ Uo. surnarrant

${ }^{441}$ Uo. „Ce qui contrôle, surveille, représente l'apparence, le masque, le langage établi, conscience surmoïque”

442 Brulotte, Gaetan: Tropismes et sous-conversation p. 39-54.
} 
felfedezi ezt a kettősséget annyiban, hogy az irodalmi értékelés és kritika folyamatos hullámzása is értelmezése szerint a dialogikusság érzetét kelti. „Nathalie Sarraute nem keresi az igazságot, hiszen a hazugságnak is megvan a maga szerepe, feladata, hanem a Tisztaságot, az Igazat (...), ami kívül áll hazugságon és igazságon."443

\section{VI.1. Név nélküli szereplö - Portrait d'un inconnu}

Sarraute első regényét 1940 és 1946 között írta, majd évek teltek el azzal, hogy kiadót keresett. Ugyanúgy nehezen tudta megjelentetni, mint a Tropizmusokat, annak ellenére, hogy ehhez a müvéhez Sartre írt előszót, valamint a Les Temps modernes-ben le is közölt belöle kisebb részletet 1946-ban. Végül 1948-ban napvilágot látott, egy kis kiadónál, Robert Marinnál ${ }^{444}$, de teljesen visszhangtalan maradt.

Már Kafkánál, a Perben is előfordult, hogy a szerző a szereplő nevét K. betüvel jelölte. Az új regény képviselői is élnek a névadásnak ezzel a lehetőségével vagy az anonimitással. Sarraute a Portrait d'un inconnu című első, a Tropizmusok technikáját folytató, de nagyobb lélegzetű regényében az egyes szám első személyű elbeszélő nézőpontjából láttatja a felbukkanó szereplőket. Émile Henriot az Új Regény irányzatot a „nézés, a tekintet iskolájának" ${ }^{45}$ nevezi. Az egyes szám első személyü elbeszélő ennek a „fókuszáló tudatnak"446, a nézőpontok sokféleségében már-már az őrültség határára sodródó, elmagányosodó énnek a minidrámáját hordozza: tragédiája, hogy arcadó gesztusai sorra kudarcot vallanak. Szembe kell nézni vele, hogy az általa megfigyelt szereplők kizárólag arctalanságukban lehetnének megragadhatók. Látszólag az apát és a lányát nézöpontok sokféleségéből kívánja összeállítani, és az olvasóval is mintegy játékot űz, mely során reményünk lehet a portrék megrajzolhatóságára, ám mindez csak kósza árnykép. A szereplők nem felelnek meg az olvasói várakozásnak, megtörik rajtuk a befogadó előzetes elvárása, tekintete. Az énregény irodalomtörténeti hagyománya alapján részben arra számítunk, hogy betekintést nyerünk majd az elbeszélő gondolataiba, érzésvilágába, másrészt hogy az őt körülvevő világról valamelyest koherens képet kaphatunk. Ezzel szemben itt ezektől eltérő írói eljárások jelennek meg.

\footnotetext{
${ }^{443}$ Uo. p. 43. „Nathalie Sarraute ne recherche pas la vérité (car le mensonge a sa propre fonction) mais le Pur, le vrai, (...) ce qui est en dehors du mensonge et de la vérité"

444 Ö maga semmit nem értett a szövegböl - Sarraute, Euvres complètes, p. 1743.

${ }^{445}$ Sarraute, Nathalie (1967). "Párbeszéd és belső párbeszéd" ford. Réz Pál in Konrád György (szerk.). A francia „új regény”, II., Bp., Európa, p. 21.

Pingaud, Bernard, "Az elutasítás iskolája" ford. Fáber András in. Konrád (1967). p. 173-178

Dort, Bernard, „Ártatlan regények?”, ford. Parancs János in. Konrád (1967). p. 181.

${ }^{446}$ Brunel - conscience focale
} 
Az említett regény esetében Sarraute nem keres Tropizmusokhoz képest újfajta nyelvhasználatot, hanem az ott kialakított regénynyelvezetet helyezi a hosszabb szövegtest által teremtett új nézőpontba. Érzetkötegek dadogó verbalizálásából felépülő spontán beszédhelyzetei a tropizmusok vonzásos-taszításos kettősségében gyakorta nézőpontváltásokból építkeznek. „Bár Sarraute említett regényei látszólag szabályosnak is tünhetnek, az a forma, amely felé képzelete ösztönösen fordul, nem a regény, és még csak nem is az Új Regény"447. Bár látszólag nagyepikai alkotást hoz létre, megmarad a Tropizmusok világából jól ismert szereplőformálásnál, melynek lényege, hogy nem az eseménysort írja le és a jellemet építi fel, hanem a szereplőn belül létrejövő nonverbális tartalmakat igyekszik megragadni, és ezzel teszi kitapinthatóvá az alakot. A szöveg terjedelme azonban alkalmat ad arra, hogy a szerző megnövelje a beszédhelyzetek, a nézőpontok, a szövegtípusok számát és nagyobb teret engedjen a tropizmus rizomatikus burjánzásának. „Tisztában voltam vele, hogy ha fejlődni szeretnék, lehetővé kell tennem e mozgássorok számára, hogy kibontakozzanak" - vallja a regényformáról a szerző ${ }^{448}$.

Ahogyan Christine Cormier $^{449}$ jegyzi meg tanulmányában, Sarraute-nál a cselekményvezetés feszültsége helyett a Portrait d'un inconnu címü regényben a tropizmus ki nem mondott valósága és a szómögöttes tartalmak megidézésére szolgáló szavak ütköztetése adja a konfliktust, az ellentétet a szereplők szintjén is. Ezeknek a minidrámáknak, konfliktusoknak a feloldására az életből ellesett pillanatok, a valójukban megidézett érzetek feltárása szolgál. A Portrait d'un inconnu sajátos poétikát társít ehhez a költői indíttatáshoz. A látszatvalóságot feltáró szint beszédet, beszélgetéseket idéz ${ }^{450}$, rövid leírásokkal operál, belső monológot, „hatékony”, valósághü írásmódot alkalmaz; ugyanakkor a tropizmusok szintje stilisztikailag elkülönül, költőivé formálódik. „Látványos egybeesés van a tropizmusokkal átitatott spontán mentális elrendeződés és az esztétikai struktúrába rendezett „,prózai alapanyag” között - a teremtés lendülete beleáll egy élettel telített pillanatba." ${ }^{451}$

\footnotetext{
447 Tison-Braun (1971). p. 24. „Bien que NS ait écrit des romans presque réguliers, la forme vers laquelle son imagination tend d'instinct n'est pas le roman, même nouveau."

${ }^{448}$ Angremy, Annie (1995). Nathalie Sarraute. Portrait d'un écrivain, Bibliotheque nationale de France, p. 21. „J'ai vu que pour progresser il fallait permettre á ces mouvements de se déployer”.

${ }^{449}$ Cormier, Christine (2000). "Topos, tropismes et toponymes dans Portrait d'un inconnu de

Nathalie Sarraute". Études françaises, 36 (1), 109-125. Elérhető: https://doi.org/10.7202/036173ar Letöltés ideje: 2020. január 3.

450 dialogue rapporté

${ }^{451}$ Tison-Braun (1971). p. 24. „Il y a une remarquable coïncidence entre l'organisation spontanée de la substance mentale selon les tropismes et celle de la 'substance romanesque' en unité esthétique - le mouvement créateur coïncide avec celui de la vie"
} 
Az arctalanítás poétikájának a regényen belüli alapja a szereplök szintjén, az apa és a lánya ellentétében láttatott formális konfliktus, valamint a beszélő én belső, tropizmikus szintjén drámaivá formálódó valódi konfliktus ellentételezése. Látszólag tehát valójában az idős, zsugori apa és a társfüggőségben szenvedő, enyhén korosodó lány közötti kapcsolat van a középpontban, valójában azonban azon a módon, azokon a nézőpontokon van hangsúly, ahogyan az elbeszélö igyekszik behatolni e két személy zárt zavaros intimitásába. Valójában az elbeszélés szintjén végig nem értjük meg, miért kergeti a narrátor azt az illanó pillanatot, azt a ködképet, délibábot, amely a két megfigyelt személy egységének titka lenne. A regény valójában a narrátor általi keresés, az arctalanítás drámai folyamata, melynek zárlatában nincs tanulság, nincs ,eredmény”, csupán egyfajta érdes magány.

A regény másik vonulata a Sartre által is megidézett müvészi jelleg. Hogyan értelmezhető, hogy számos intertextuális utalás, megidézett mủvészi pillanat szerepel a regényben? A narrátornak a művészi élménnyel való találkozása mindig a tropizmus szintjén zajlik: a narrátor egyik 'deterritorializációs' gyakorlata, hogy az ismert utcákat 'idegenként' szemléli, s sajátos módszere segítségével asszociál: emlékekre, irodalmi vagy más müvészi alkotásokra, például festményekre, még képeslapokra is. „Ez az eljárás életet ad a megszokásba rögzült valóságnak, ennek a gyakorlatnak köszönhetően a dolgok mintegy 'életre kelnek'."452 A központi szereplöpárt Sarraute hosszas fejtegetésében hasonlítja Tolsztoj Háború és béke címü regényében szereplő Bolkonszij herceghez és Marie-hoz, a lányához ${ }^{453}$. Ám ez az irodalmi fejtegetés csak egy a személyük felépítésében résztvevő számos nézőpont közül. Értelmezésem szerint a müvészi utalások - a címmel is összefüggésben - azért szerepelnek a müben, hogy felhívják a figyelmünket a szöveg központi mozzanatára, az ismeretlen arcképére.

Az 'ismeretlen arckép' központi metafora, a sokszoros ismeretlenség, a megismerhetetlenség, az arctalanított tropizmus-foglalatok képe. Ahogyan Sarraute fogalmaz:

„Valójában Balzactól indultam el (...), de annak a felfedezése érdekelt, hogy a modernségben milyen módon lehet megalkotni Eugénie Grandet-t. Természetesen anélkül, hogy nagyképűen a mestermű szintjére kívánnám emelni regényemet. Számomra fontos volt, hogy ne olyan történetet meséljek, mint a hagyományos regények, hanem másfajtát, olyant, amelyben a tropizmusok, azaz a tudat belső mozgássorai kibontakozhatnak.

\footnotetext{
${ }^{452}$ Cormier (2000). „Ce procédé donne vie à ce qui s'est figé dans la familiarité, grâce à cet exercice les endroits 'paraissent s'animer'"

Sarraute, Nathalie (1956). p. 28. 'autre aspect' - más nézőpont

${ }^{453}$ Andrej Nyikolajevics Bolkonszkij herceg (André) Marja Nyikolajevna Bolkonszkaja hercegnő (Marie)
} 
Ezért van az, hogy regényemben a szereplök látszatvilága nem érdekel, hanem belső mozdulatsoraikat igyekszem újraalkotni. Végül is, leginkább az a megfigyelő vagyok, aki lelkesen személi, milyen ismeretlen folyamatok játszódnak le az apa és a lánya viszonyában - 'tropizmus-kereső' vagyok."

Ismeretlen, mert ismeretlen a festője és ismeretlen maga a személy is, akiről a kép készült. Az olvasó esetleg ismeretlenül, értetlenül állhat azelőtt, hogy vajon miért hangsúlyos a narrátor és a kép viszonya és miért emeli a szerző a címbe magát a festményt. ${ }^{455}$

„Egy portré. Egy ismeretlen arcképe, egy meg nem nevezett, meg nem nevezhető személyé. Egy bizonytalan vonalvezetésű arckép. Sartre-nál és Nathalie Sarraute-nál is a múzeum az a hely, ahol a határozott vonalvezetésű portrék (jellemek, helyzetek, nevek) és a kölcsönösségben forrásozó szereplöalak szemlélete összecsap". 456

A kép és az azzal való rendszeres és már-már mániákussá váló találkozás az elbeszélő én minidrámájának megoldását jelképezi. A narrátor az apa-lány pár nézőpontokból kirajzolódó megismerhetőségének az ellehetetlenülését látja benne anélkül, hogy ezt megfogalmazná magában. A művészet lényege, hogy általa csak érezzük lényünk lényegét, de esetleg valódi fogalmi megragadására nem vagyunk képesek. Az ismeretlen arcképének egészleges befogadása mintegy a narrátor megújuló világszemléletének metaforája. Látszólag az író szót szó után írva alkot, a festő ecsetvonásról ecsetvonásra halad mủvével, valójában a mű teljessége, a mủ mint olyan által keltett 'érzet' adja a művészi élményt ${ }^{457}$. A regény elbeszélőjének léte maga a műalkotás. Megfigyeléseinek sokszínűségéből, egyen-egyenként egymás mellé helyezett valóságából rakná össze a megfigyelt képet, de az Ismeretlen arcképéhez való ragaszkodása egzisztenciálisan azt súgja számára, hogy csak arctalanságukban, személyüktől és jelentésüktől megfosztva, egészlegességükben ragadhatja meg azokat, akiket megfigyel.

\footnotetext{
${ }^{454}$ Saporta, Marc (1984). "Entretien avec Nathalie Sarraute”, L’Arc, no. 95. 1984. p. 6. „En réalité, je suis partie de Balzac (...) mais ce qui m'intéressait, c'était de découvrir comment un moderne écrirait aujourd'hui Eugénie Grandet. Sans prétendre, bien sur, á égaler en qualité ce chef-d'œuvre. Ce qui me paraissait important, ce n'était pas l'histoire telle que la racontait le roman traditionnel, mais une autre histoire, celle des mouvements sousjacents de la conscience - ce que j'appelle les 'tropismes'. De sort qu'il y a, dans ce roman, des personnages en trompe-l'œil, qui ne m'intéressent pas, et des mouvements á l'intérieur d'eux-mêmes et que je cherche á recréer. En fait, je suis plutôt cet observateur qui se passionne pour ce qui se passe d'encore inconnu chez le père et chez la fille et qui est 'chasseur de tropismes'."

${ }^{455}$ Bruel, Pierre (1985). "'Dieppe .. on parlait de Dieppe': Essai de lecture comparatiste d'une page de Nathalie Sarraute", Neohelicon: Acta Comparationis Litterarum Universarum, vol. 12, n 1 (1985), p. 17-25. Elérhető : https://link.springer.com/article/10.1007/BF02092933, Letöltés ideje : 2020. január 18.

${ }^{456}$ Raillard, Georges (2000). "Notes en marge d'un 'livre difficile': Portrait d'un inconnu" in Littérature No. 118. juin 2000. p. 35-42. Elérhető : https://www.jstor.org/stable/41704770?readnow=1\&seq=5\#page_scan_tab_contents, Letöltés ideje : 2020. január 18. „Un portrait. Portrait de l'inconnu, de l'innommé, de l'innommable. Et portraits a contours vagues. Le musée est chez Nathalie Sarraute et chez Sartre le lieu de la confrontation entre les portraits á contours (l'arrêt en caractères, situations, noms) et l'espace de l'échange."

457 Ehwenzweig Anton (1974). L'ordre caché de l'art, essai sur la psychologie de l'imagination artistique, Gallimard - teljes elmélet a müvészetértelmezés-művészetbefogadás ilyen egészleges lehetőségéről
} 
Ahhoz, hogy az „élet titkos lüktetését”458 érzékeltetni tudja, a belső rezdüléseket szöveggé formálni, az írás stílusa gyakran fordul a különböző érzékterületek összekapcsolásához, szövege szinesztézikusan építkezik, illetve olyan képeket használ, amelyek taktilisak $^{459}$. A testközeli megidézése, az érintés, a hallás összefüggésbe kerül Sarraute regényében akár az intellektuális folyamatokkal: a gondolkodással, a felfogással, az írással, valójában magával a létezéssel, illetve azt garantálja, hogy az élet valósága járja át a szöveget. A sarraute-i szubjektum, a tropizmust kereső én inkarnációja, az elbeszélő a Portrait d'un inconnu-ben nem rendelkezik hagyományos filozófiai értelemben vett cogitoval, akár ő is mondhatná magáról azt, amit az írónő: „nem létezem”. Azokból a látott, megérintett, megtapasztalt érzetkötegekből formálódik a vele azonosítható szubjektumköd, amelyeket a különböző helyzetek átélésekor, látványok, hangok, illatok befogadásakor átél. Az olvasó belső látásának kiélesítésére szolgálnak ezek az írói eljárások, céljuk, hogy ne a befogadó tudatában, hanem érzékeiben leljenek visszhangra. A haptikus látást igénylő olvasatot a prózaszöveg ritmikussága is segíti: ,a regényszöveget ritmusok szövik át”460. A ritmus, az érzékekre ható (látást, hallást idéző) szójelentések elsődleges befogadása megelőzi a jelentés kibontakozását, kibontását.

Az alábbi regényrészlet azt mutatja meg, hogy a képzőművészet, a vizualitásunkra apelláló müalkotás is milyen mértékig a befogadó és az alkotás közötti valóságos közvetlen, kölcsönös testkontaktus. A XXII. Tropizmus kirekesztettjére emlékeztet ez a fajta befogadói attitüd: számára belső lelki igény volt, hogy már-már valóságosan is mindent megérinthessen. A sarraute-i szereplőknek nincs jelleme, csupán attitüdje, érzethullámai, pozitív vagy negatív ethoszt érzékelünk szubjektumkipárolgásaiból. Ezeknek az érzékeltetésére szolgálnak a haptikus látásunkat élesítő szinesztéziák, taktilis képek. A regénybeli Öreg például nem jellemében, hanem ethoszában ellentételezett az elbeszélő énnel, már-már elölegzi a Tu ne t'aimes pas, önmagát tökéletesen szeretni tudó ő figuráját ${ }^{461}$. Azért mozdul ki, hogy megcsodálja a lába előtt elterülő képeslapszépségű panorámát, hogy „megszelídítse az őt körülvevő dolgokat, távol tartsa őket önmagától, ne tapadjon rájuk, úgy éljen belőlük, mint

\footnotetext{
${ }^{458}$ Sarraute (1996). "Roman et réalité" in Oeuvres completes, p. 1652. "la pulsation secrète de la vie"

${ }^{459}$ Courson, Nathalie (2008). "Nathalie Sarraute, écrivain du toucher", Poétique, 2008/4 n 156, pages 473-482., Elérhető: https://www.cairn.info/revue-poetique-2008-4-page-473.htm, Letöltés ideje: 2020. 01. 18.

460 Sarraute (1996). "Langage dans l'art du roman" in Oeuvres completes, p 1686. „le langage du roman se soumet à des rythmes"

${ }^{461}$ Courson (2008).
} 
egy remegő puha lárva, egy élősködő" 462 . Az elbeszélőnek a festménnyel való találkozása mintegy szövegszerü ellenpontja a fenti soroknak. Nem karakterükben ellentételezi a szerző a két megjelenített szereplő-foglalatot, hanem érzeteikben, átfutó gondolataikban, attitüdjükben, egyszóval tropizmikus létszintjük megéléseiben ${ }^{463}$. Ahogyan a festményt érzékeli, úgy, olyan attitüddel igyekszik a narrátor magába zárni az Öreg és a Lány alakját.

Il me parut, cette fois, plutôt plus étrange encore qu'il ne m'avait paru autrefois. Les lignes de son visage, de son jabot de dentelles, de son pourpoint, de ses mains, semblaient être les contours fragmentaires et incertains que découvrent à tâtons, que palpent les doigts hésitants d'un aveugle. On aurait dit qu'ici l'effort, le doute, le tourment avaient été surpris par une catastrophe soudaine et qu'ils étaient demeurés là, fixés en plein mouvements, comme ces cadavres qui restent pétrifiés dans l'attitude ou la mort les a frappés. Ses yeux semblaient avoir échappé au cataclysme et avoir atteint le but, l'achèvement: ils paraissaient avoir tiré à eux et concentré en eux toute l'intensité, la vie qui manquaient à ses traits encore informes et disloqués. Ils semblaient ne pas appartenir tout à fait à ce visage et faisaient penser aux yeux que doivent avoir ces êtres enchantés dans le corps desquels un charme retient captifs les princes et les princesses des contes de fées. L'appel qu'ils lançaient, pathétique, insistant, faisait sentir d'une manière étrange et rendait tragique son silence. ${ }^{464}$

\begin{abstract}
Ezúttal még különösebbnek tünt számomra, mint valaha. Arca, csipkegallérja, dolmánya, két keze körvonalai olyannyira töredékesnek, tétovának látszottak, mintha egy vak bizonytalanul érzékelö ujjai tapintanák ki. Az erőfeszítés, a kétség, a zaklatottság mozdulatsorai látszólag a hirtelen katasztrófa meglepte időben rekedtek, csaknem a halál dermesztő percében ért testek pillanat-merevsége érte őket. Szemei látszólag elkerülték a kataklizmát és célt értek, kiteljesedtek: a formátlan, szétmorzsolt vonásokból kivont életintenzitás mintha hozzájuk húzott, bennük sürüsödött volna. Talán nem is tartoznak ehhez az archoz? - tündérmesék hercegeit és hercegnőit bújtató bübáj-alakok tekintete villan így. Átható és patetikus hívásuk különös módon tette kitapinthatóvá és tragikussá végtelen csendjét.
\end{abstract}

Az idézett részlet, a festménnyel való találkozás pillanata sürített foglalta a narrátor teljes lényének. A deleuze-i haptikus, tapintó látás segítségével alkotó festő megidézése arra

\footnotetext{
462 Sarraute (1956). Portrait d'un inconnu p. 88. Deleuze lárva-szubjektuma is eszünkbe juthat. „dompter les choses autour de lui, les tenir à distance, au lieu d'aller se coller à elles, vivre d'elles en larve tremblante et molle, en parasite".

463 Rachel Boué (1997). "Un regard tactile" in Nathalie Sarraute. La Sensation en quête de parole, Paris, L'Harmattan, p. 156-158.

${ }^{464}$ Sarraute (1956). Portrait d'un inconnu. p. 80.
} 
utal, hogy a művészet lényege valami láthatatlan, mondhatatlan érzékelhetővé tétele, és hogy a regény elbeszélőjének problémája akkor oldódik meg, amikor a müvészi alkotásnakbefogadásnak ezt az eljárását átviszi való életeseményeinek befogadására-értelmezésére. Elvégzi a két megfigyelt alak arctalanítását, rájön, hogy értelmezhetetlenségükben és személytelenségükben, egységként, egészként befogadva őket lehet csak lényüket értelmezni. A portré bizonytalan körvonalai éles ellentétben állnak a szövegben megjelenő átható szempárral, amelyröl nehéz lenne nem asszociálnunk a Tropizmusok első szövegének pislogásban fixálódott viaszbabáira. Már-már önironikus szerepcsere történik: a festő nem lát, az alkotása azonban átható tekintettel fürkészi alkotóját és befogadóját.

„A Portrait d'un inconnu-ben és a Martereau-ban, mivel azt feltételeztem, hogy nem fogják a tropizmusokat érzékelni, beiktattam egy szereplőt, egyfajta „örültet”, aki idejét azzal tölti, hogy tropizmusokat keres másoknál (...) és aki nem mindig lel rájuk, illetve többször is a látszat falába ütközik. Erre a Planetárium esetében már nem volt szükségem. Bizalmat találtam. Azt mondtam magamban: 'Mindenkinek vannak ilyen belső mozgássorai, mindenki átérzi öket', nem volt többé szükségem erre a valakire, aki keresi, akire rámordulhatunk, mert nem találja." ${ }^{365}$

\section{VI.2. A szereplő-alak magánya - Planetárium}

Az 1959-ben íródott Planétarium ${ }^{466}$ címü regényt azért üdvözölte az olvasóközönség és a kritika, mert talált benne olyan szereplö-vonatkozásokat, amelyek a klasszikus regényvilágra jellemzők. Látszólag számos karakter jelenik meg, legalább tíz-tizenkettő, és legtöbbjüket névvel is ellátta a szerzőnő. Amikor azonban Sarraute nevet ad a szereplőknek, az banalitásukra utal és nem arra, hogy sajátos, egyénített jellemük van, például Alain, Berthe néni. A tropizmus középpontjában ebben a regényben nem belsőleg megélt, egyszemélyes érzetkötegek állnak, mint a Tropizmusok világában, hanem a tárgyakhoz, életeseményekhez és személyekhez füződő viszonyrendszerek: fotel, lakás, ajtó, irodalom, karrier, nagynéni, müvészvilágbeli „főguru” - ezek látszólag tárgyak, élethelyzetek, személyek, valójában Sarraute regényében alkalmasak arra, hogy tropizmusokat indítsanak el ${ }^{467}$. Az ajtó, az ajtó becsapódása, az ajtó-problematika számos Sarraute-szövegben fordul elő és feltehetően az

\footnotetext{
${ }^{465}$ Sarraute, Nathalie (1987). coll. 'Qui etes-vous?' édition de La Manufacture, Lyon, p. 60-61. „Dans Portrait d'un inconnu et dans Martereau, comme je pensais qu'on ne voyait pas ces tropismes, que personne ne les percevait, j'avais effectivement introduit un personnage, une sorte de 'fou' qui passait son temps á les chercher chez les autres (...), qui se heurtait á l'apparence et n'arrivait pas toujours á trouver. Et puis, á partir de la, dans Le Planétarium, je n'en ai plus eu besoin J'ai pris confiance. Je me suis dit: 'Tout le monde les a, ces mouvements, tout le monde les éprouve', je n'avais alors plus besoin de quelqu'un qui cherche, qu'on rabroue, qui ne trouve pas."

${ }^{466}$ Sarraute, Nathalie, Le planétarium, Paris, Gallimard, 1959.

${ }^{467}$ Raffy, Sabine (2002) p. 15.
} 
interperszonális kommunikációban beálló zavarokat jeleníti $\operatorname{meg}^{468}$. A szereplők megnyilatkozásformáinak ritmusát ebben a regényben egyedülállóan a szó/szómögöttes, valóság/látszat, kimondás/tropizmus binaritása adja ${ }^{469}$, hiszen még narrátor sincs, és a tropizmusok szinte kizárólag verbális jellegüek.

A személyekhez való viszonyulás egyúttal mintha fogalmakhoz, prioritásokhoz való kapcsolódást is jelentene - irigység, karrierizmus, zsugoriság, siker, féltékenység, álompár, család, anélkül, hogy, - narratíva hiányában - megfogalmazódna ezekkel az értékekkel kapcsolatban bármiféle erkölcsi hozzáállás. Ez az elbeszéléstechnika és szereplőfelfogás azt eredményezi, hogy többé egyetlen Sarraute-regényben sem lesz kísérlet valamiféle külső fokalizációra ${ }^{470}$. A tropizmus-narráció lényege, hogy vagy a beszédet idézi a szöveg, vagy a szómögöttest, tehát a regényvalóság a szereplők interszubjektív közegében szerveződik. A szerző későbbi munkáiban ennek folyománya, hogy a szereplő-foglalatok 'hangokká' válnak és a későbbiekben szinte mindig személyes névmásként jelennek meg a szövegekben.

Hogyan valósul meg a Planetárium esetében a sarraute-i arctalanítás poétikája? Ebben a regényben Sarraute úgy építi fel szereplőit, hogy látszólag arcot ad nekik: nevet, társadalmi státuszt, kapcsolatrendszert, létrehozza motivációikat, mintha valóságos regényt írna. Az arctalanítást itt nem Sarraute végzi el, hanem pontosan az arctalanítás a regény lényegi történése, a fordulatok a tropizmusok segítségével létrejövő, a szereplőket egymás ellen fordító arctalanító gesztusok. Maguk a szereplők jönnek rá, hogy csak másolatok. A regénynek azért Planetárium a címe, mert az alakok nem mások, mint csillagmásolatok, látszatok. Nem a csillagokat nézzük a szabad ég alatt, hanem a planetáriumban szemléljük az égitestek másolatait. ${ }^{471}$

\begin{abstract}
„Valamennyi regényem közül a Planetárium aratta a legnagyobb sikert. Természetesen egy félreértésnek köszönhetően. Cselekményvezetést, keresztnévvel és vezetéknévvel ellátott szereplőket olvasnak ki belőle. Az olvasóközönség emiatt lélegzett fel. Nem látta a látszatvalóságot, vagy inkább megszerette azt, ami csupán látszatvalóság volt. Beleesett abba a csapdába, amelybe a könyv szándékolatlanul csalta." ${ }^{472}$
\end{abstract}

\footnotetext{
${ }^{468}$ Az ajtó-szimbólum bibliai gyökere: Én vagyok az ajtó - Jézuson keresztül lehet az Atyához menni. Szabó Magda(2016). Az ajtó, Jaffa, Raffy (2002). p. 16. - külön tanulmányt érdemelhetne a téma

469 Adert, Roland (1996). Les mots des autres: Flaubert, Sarraute, Pinget, Presse Universitaire, p. 198.

${ }^{470}$ Genette, Gérard (1972). Figures III. p. 209.

${ }^{471}$ Rykner, Amaud (1991). Nathalie Sarraute, Paris, Éd. du Seul, p. 181.

${ }^{472}$ Sarraute, Nathalie (1979). "Comment j'ai écrit certains de mes livres. Entretien avec Lucette Finas" Erudit https://www.erudit.org/fr/revues/etudlitt/1979-v12-n3-etudlitt2211/500503ar/ "De tous mes romans, Le planétarium est celui qui a obtenu le plus de succès. À la faveur d'un malentendu, naturellement. On y trouve une intrigue, les personnages portent de noms et des prénoms. Le public n'a pas manqué de s'en réjouir. Il n'a pas vu le trompe-l'œil, ou plutôt il a aimé ce qui n'était qu'un trompe-l'œil. Il est tombé dans le piège que le livre lui tendait sans le vouloir."
} 
Gisèle, Alain ifjú hitvese fogalmazza meg azt a számára revelatív értékű mondatot, hogy ,a test soha nem téved ${ }^{473}$ ". Az ébreszti rá párkapcsolati problémájára, és főleg annak hazugságalapjára, hogy valósággal testileg éli át ennek a ráébredésnek a szorongását. A tropizmus megélése Gisèle esetében sommás végkövetkeztetéshez vezet: „Nincs teljes egység senkivel, ezek a történetek csak a regényekben fordulnak elő" ${ }^{474}$ Megtörténik a párkapcsolat arctalanítása: „Minden hamis... (...) Alain és ő: hamis. ...., látszat, képek, hogy ábrázolják a boldogságot, de mögötte, van valami..."

Elle sent qu'il la regarde, elle sait ce qu'il voit : elle le fait penser à un renardeau, à un petit animal des bois, sauvage, capricieux... Il regarde son nez charmant, un peu court, mais si fin, si droit, fraîchement poudré, duveté, doré... ses yeux deviennent plus sombres quand elle fixe quelque chose ainsi avec cette intensité... le bleu de vos yeux tourne au violet, vos yeux sont comme des violettes... le grand garçon blond qui avait l'air d'un Suédois lui avait dit cela, assis près d'elle sur le banc, se reposant, regardant les autres jouer... ${ }^{476}$
„Érzi, hogy Alain nézi, tudja, hogy mit lát: kölyökrókára emlékeztet, kis szeszélyes erdei vadra... Nézi a bájos, kicsit rövidecske, de finom vonalú, egyenes, frissen púderozott, pihés, aranypihés orrát... a szeme színe elsötétül, amikor valamit így, ilyen erősen néz... ibolyaszínre vált a kerek szeme, ibolya a két szeme... az a magas szőke fiú mondta ezt neki, aki úgy nézett ki, mint egy svéd ; ott ült mellette a padon, pihentek, nézték, hogyan játszanak a többiek..."

Gisèle arcának leírása Alain nézőpontjából jelenik meg, a leírás stílusa egyértelmüsíti az intimitást, a szerelmes tekintetének pozitív árnyalatú átszínező gesztusait. Ugyanakkor a szövegzárlat emlékfoszlánya azonnal arctalanítja a férfiszereplő által felépített női szereplőt: más is látta őt már-már ugyanígy. A jelenidő a leírás domináns eleme, hiszen ez az az igeidőtípus, amely a leginkább alkalmas a szómögöttes tartalmak verbalizálására. Narratív technikaként ebben a regényében szívesen alkalmazza Sarraute a style indirecte libre-et vagy a belső monológot is, melyek elsődleges idővonatkozása szintén a jelenidő. A jelenidejü leírással mintha közvetlenül az olvasó lépne be a szereplők tudatába, s így egyszerre tudhatná magáénak a férfi és a női nézőpontot. Nincs narrátor, a szómögöttes tartalmak halmozása a női szereplő lelkiállapotának, tudatállapotának belső szemléletére is rávilágít, valamint sejteti a férfi szereplő tudatállapotának a női szereplő általi megélését. Több annál, mint annak

\footnotetext{
${ }^{473}$ Gosselin-Noat, Monique (2002). "Nathalie Sarraute et la recherche de la vérité" in Critique janvier-février 2002. 656-657. p. 29. idézi : „Le corps ne se trompe jamais”.

${ }^{474}$ Uo. „Il n’y a de fusion complète avec personne, ce sont des histoires qu'on raconte dans les romans”.

${ }^{475}$ Uo. „Tout est faux... (...) c'est faux, Alain et elle. Du toc, du trompe-l'œil, des images pour représenter le bonheur, et derrière il y a quelque chose...”.

${ }^{476}$ U.o., p. 108.
} 
közvetítése: kiben mi játszódik le - úgynevezett pszicho-narráció ${ }^{477}$ a jelenben. A pszichoelbeszélés mintegy Alain szavait visszhangozza, szóról szóra. A múlt idejü elbeszélés, amelynek lényege múltbeli események egymásutánjának rögzítése, nem lenne képes ennyi változó nézőpont, szemszög, váltás, áttétel közvetítésére. A pszicho-elbeszélés folytatódik az elgondolkodást, a megállást elősegítő három pont után egy style indirecte libre ${ }^{478}$-ben szereplő mondattal : „,szeme kékje ibolyát idéz...”, még mindig jelenben folytatódik. Az elbeszélés a következő mondatban a múlt időt, a plus-que-parfait-t jeleníti meg. A plus-queparfait olyan múlt idő, amely csupán funkcionálisan létezik, az időegyeztetések során használjuk csupán, és az az igeidőtípus, amely a leginkább szóbelivé tehet egy szöveget. Csak egy igét találunk ebben a rövid szakaszban, amely plus que parfait-ban szerepel, ezen kívül egy imparfait igealak jelenik meg a múltat felidézendő, illetve participe alakok, amelyeket igenevekkel fordíthatna a fordító, ám igésíti őket ${ }^{479}$. Az igeneves fordítás éreztette volna az eredeti igealakok statikusságát, tudniillik azt, hogy szemléletükben közelebb állnak a jelenhez, mint a cselekménysort idéző múlthoz. A múltidézés tehát nem a cselekménysor narrálása miatt van, hanem hogy megvilágítson valamit a jelentből, az emlékkel erösebben segítsen fókuszálni a jelen pillanat milyenségére.

Amikor Nathalie Sarraute ezekben a regényekben a szómögöttes felé fordul, akkor kevésbé törekszik a sürítésre és a drámával telített pillanat állóképbe merevítésére, mint inkább arra, hogy különféle elbeszélői eljárások segítségével sikerüljön megvilágítania azokat a mögöttes tartalmakat, amelyek egy-egy tekintet vagy szó mögött rejlenek. Ezeknek a nyelvistilisztikai felidéző mechanizmusoknak a mikéntje rendkívül változatos, és olyan rugalmas igeidőre van szüksége, amely szinte bármilyen narratív variánsra képes. Ez pedig kizárólag a jelenidő. A Tropizmusok világához képest ezzel változást hoz, mert ott szinte kizárólagosan alkalmazta az imparfait-t. A fenti példában például a megszólalás szintjei a következők: a női főszereplő, Gisèle belső beszédének megidézése, a női főszereplő által a férfi főszereplő, Alain belső beszédének felidézése, és Gisèle egyik régi emlékének felidézése, amikor a svédnek látszó fiatalemberrel megélt pillanata kerül felszínre, párhuzamba állítva az akkori és a mostani léthelyzetét. Newman azért nevezi a Planetárium elbeszéléstechnikáját „diskuzusok költészetnek" ${ }^{\prime 400}$, mert szinte valamennyi 'cselekvés' a regényben egy-egy megszólalás, amelyet a szómögöttes tartalmak kibontása kísér. Van olyan értelmező, aki szerint a

\footnotetext{
477 Cohn (1981). p. 25.

${ }^{478}$ Cohn (1981). p. 38. un monologue narrativisé

${ }^{479}$ ford. Farkas Márta

${ }^{480}$ Newman, B. (1976). Une Poésie des discours : essai sur les romans de Nathalie Sarraute. Paris : Droz, poésie des discours
} 
Planetáriumban a narrátor nem tünik el a különböző hangok és belső hangok hálójában, hanem ,átadja a helyét, az egyes szám első személyü tudat nézőpontjáét, hogy valamennyi szereplő legyen egyszerre." ${ }^{481}$ Ugyanez az értelmező említi a láthatatlanná váló elbeszélőt ${ }^{482}$.

Le ciel tourne au-dessus de lui, les astres bougent, il voit se déplacer les planètes, un vertige, une angoisse, un sentiment de panique le prend, tout bascule d'un coup, se renverse... elle-même s'éloigne, elle disparait de l'autre côté... Mais il ne veut pas la lâcher, il peut la suivre, les suivre làbas, il vient... seulement qu'elle ne le repousse pas, qu'elle ne l'abandonne pas... il est avec eux, de leur côté...' Eh bien, figurez-vous, tout ce que vous me dites là, je l'ai un peu pensé aussi quand j'ai vu Lebat la dernière fois... Ça m'a même rendu un peu envieux... Je me suis senti coupable... Il donne une telle impression de force, de sérénité... Il y a chez lui, dans sa façon de tout survoler, une espèce de renoncement... très rare... Il a réussi... je dois vous avouer que c'est ce que j'envie le plus aux autres dans la vie... une ascèse. Il y a en lui de l'unité, une grande pureté, aucun mélange... Je pensais tout ça moi aussi, l'autre jour, en lui parlant, je me sentais indigne, j'ai failli, comme un gosse, lui dire que j'aimerais tellement le voir plus souvent, devenir son ami..."483
„Megperdül fölötte az ég, elmozdulnak a csillagok, látja, amint odébb ballagnak a bolygók, szédül, szorongás, pánik keríti hatalmába, hirtelen minden felbillen, összedöl... az asszony is eltávolodik, eltünik a másik oldalon... De nem akarja elengedni, követni tudja, a többieket is követi, megy ö is... csak ne lökje el magától, ne hagyja el... velük van, az ő oldalukon...' Nos, képzelje, mindezt, amit most elmondott, kicsit én is végiggondoltam a múltkor, amikor Lebatval találkoztam... Kicsit meg is irigyeltem.. Bünösnek éreztem magam... Olyan erö, kiegyensúlyozott derü árad belőle... Ahogy minden fölött átrepül, van benne valami lemondás... és ez nagyon ritka...Neki sikerült... bevallom, ezt irigylem az életben a legjobban a többiektől... eljutni az aszkézishez. Egység, nagyfokú tisztaság van benne, a keveredés árnyéka nélkül... Én is gondoltam ezekre a múltkor, amikor vele beszéltem, méltatlannak éreztem magam, majdnem megmondtam neki, mint valami kölyök, hogy nagyon szeretnék többször találkozni vele, a barátja lenni..."

Sarraute-nál a tekintet mintegy „letapogatja” a valóságot, érintés révén „lát”, ezzel oldja fel azt a bizalmatlanságot, ami a belső és a külső valóság, az alkotó és az olvasó, a szöveg és az értelmező, a mélység és a felszín között feszül számára, s amelynek feloldására tett kísérletei újra és újra ennek a célnak nekifutó szövegei ${ }^{485}$. A látott-hallott valóság látszatvilágával szembeni gyanakvásra gyógyír lehet a tapintással kapcsolatos képsorok

\footnotetext{
481 „Il abandonne sa place de conscience unique pour être tous les personnages à la fois.” SOUSA, Germana H. P. de, "L'usage de la parole chez Nathalie Sarraute », Graphos: Revista da Pós-Graduação em Letras, vol. 13, $\mathrm{n}^{\circ} 2$ (2011), p. 1-9. (Article de revue)

482 devenir invisible - U.o.

483 Sarraute, Nathalie (1959). Le Planétarium, Gallimard, p. 249.

484 ford. Farkas Márta

485 Serreau, Geneviève (1959). "Nathalie Sarraute nous parle du Planétarium" in Les Lettres nouvelles, 29 avril 1959.
} 
ritmikus ismétlése ${ }^{486}$. Alain és Gisèle Guimier kapcsolatában is felmerül a közelség-távolság problematika, de a családon belüli kapcsolatrendszerek viszonylatában is újra és újra tematizálja az írónő ugyanezt. Nem beszélve Alain és Germaine Lemaire kapcsolatában, ahol a megközelíthetetlenség, az érinthetetlenség a fenti szövegben is megjelenik: „ne lökje el magától”. „Hát igen... körülnéz...”. Az arctalanítás poétikája itt a szereplők kapcsolatrendszerének a szó / szómögöttes-ben való dekonstrukciója segítségével valósul meg úgy, hogy az alakok a folyamatot maguk készítik elő majd végzik el. Nekik kell szembenézniük arctalan mivoltukkal.

\section{VI.3. A szereplök tárgyak vagy elvont dolgok - Les Fruits d'or}

A Tropizmusok filozófiai háttereként már szó volt a fenomenológiai nézőpontról, amely az Új Regény egyik elsődleges alapállása. Említettük Robbe-Grillet értelmezését, amely szerint a tárgyak függetlenek, szabadok, nincs jelentésük csak jelenlétük, ennek közvetítését pedig a leíró szövegtípussal képzeli el. Ez az elméleti hozzáállás részben egybevág a sarraute-i arctalanás poétikájával, a személytelenítés és a jelentéstől való felszabadítás tekintetében, ugyanakkor, ellentétben az Új Regénnyel, ahol tárgyak vagy dolgok leírása kerül a szereplők helyébe, Sarraute-nál a tárgyak, dolgok vagy fogalmak lesznek maguk a szereplők, és az ő ethoszukkal való már-már fizikális, látással-hallással megvalósuló érintkezés adja a szövegek tropizmikus folyamatait. Az Új Regény szemlélete az elidegenedést tükrözi: „Az ember nézi a világot, de a világ nem tekint rá vissza.”487 Nathalie Sarraute prózájában azonban a tropizmus-foglalatok, még ha ki is lépnek antropomorf személy-személyiségkeretükből, olyanok, mintha élnének, megmozdulásaik, megélénkülésük, legyenek látszólag mégoly hétköznapiak vagy sztereotipikusak is, feszültségeket, mozgásokat indíthatnak el. A szöveg metaforikusan müködik ebben a formájában, kapcsolatokat teremt és keres. Ezért nem keresi a stílus szépségét, csupán a stílust, és ezért nem elidegenít.

A szereplők neveit gyakran helyettesítik személyes névmások a XX. századi regényben, ezen belül az Új Regényben. Irodalomtörténetileg ez a pszichoanalitikus irodalom és szemlélet kialakulásának és elterjedésének köszönhetően valósult meg, és az első ilyen személyes névmás-narrátor általában az én volt, pl. Joyce müveiben. A. Robbe-Grillet $A$

${ }^{486}$ Clayton Alain (1989). Nathalie Sarraute ou le tremblement de l'écriture, Paris, Minard. Le geste créateur de saisie

487 „L'homme regarde le mode et le monde ne le regarde pas.” Ricardou mondatában külön érdekesség a francia regarder szó kétértelműsége: nézni valamit és qch regarde qn. - köze van hozzá. Cela ne me regarde pas. Nincs közöm hozzá 
rések ${ }^{488}$ címü regénye nem véletlenül kapta ezt a magyar címet. Robbe-Grillet a végsőkig sarkítja az én megfigyelői attitüdjének kiteljesedését. Előfordul, hogy a narrátor egyes szám harmadik személyben használja a személyes névmást a szereplöre - ő (il, elle franciául). Michel Butornál előfordul az ön is. Sarraute-nál is már többször szembesültünk azzal, hogy a szöveg szereplöje névmás. Az énelbeszélés változatai több Sarraute-regényre is jellemzők voltak - az előző fejezetek egyikében elemzett Portrait d'un inconnu meg nem nevezett narrátora például je.

Az Amit csak a madarak látnak c. esszében a szómögöttes tartalmak feltárását fokról fokra alapozza meg a szerző, amelyhez az alaphangot a szöveg alanyaként bevezetett on általános alany adja meg. Ez az on a leggazdagabb szemantikájú francia személyes névmás. ${ }^{489}$ A mondatszerkezetekben úgy viselkedik, mint egy átlagos személyes névmás, egyes szám harmadik személyben ragozunk utána, ám szemantikájára olyan „légneműség”"490 jellemző, amely lehetővé teszi számára, hogy végül is minden szemantikai kategória alól kivonja magát. Értelmezhető úgy, hogy én, te, vagy akár úgy hogy $t i$ vagy $m i$, anélkül, hogy akár egyszer is pontosan megfelelne bármelyikkel való szemantikai azonosításnak. ${ }^{491} \mathrm{Ez}$ a szemantikai lebegés vagy más szóval légnemüség, amely az on személyes névmás részeként értelmezhető, a retorikában felcserélhetőséget jelent. ${ }^{492}$ Ennek a nyelvi szinten megjelenő felcserélhetőségnek a szemantikájából építkezik Sarraute, amikor az olvasót (elvileg az alkotás mint üzenet befogadója) azonosítja összekapcsolaja az üzenet adójával, a műalkotás alanyával, a szerzővel. Tudatosan elkeveri a szálakat.

A többes szám harmadik személyü igehasználattal, és a „közönség”, illetve „kritikusok” megnevezéssel Sarraute ettől függetlenül konkretizálja esszéje tárgyát. Hosszan fejtegeti az általuk megvalósított olvasás módját, többek között kiemelve, hogy a közönség úgy „fal fel” némely alkotásokat, ,akárcsak valamely ínycsiklandó finomságot”493. A továbbiakat idézem, mert itt vált át Sarraute a fikciós műveiből jól ismert szómögöttesre.

„Bizony, ezek a leginkább ízletesek, vallják az olvasók, és miért is rejtegetnék ízlésbeli vonzódásukat, ha a leginkább köztiszteletben álló kritikusok osztják a nézeteiket? Ezek a „falatok” még ízletesebbek,

\footnotetext{
${ }^{488}$ La jalousie - kétértelmü szó: redőny, féltékenység (féltékeny tekintet) - eredeti cím

${ }^{489}$ Herschberg-Pierrot (1993). p. 27-43.

${ }^{490}$ Maingueneau, Dominique (1991). L'énonciation en linguistique française, Paris, Hachette, p. 20.

${ }^{491}$ Uo.

${ }^{492}$ Herschberg-Pierrot (1993). p. 43.

Groupe $\mu$ (1982). Rhétorique générale, Paris, Seuil, 1982, p. 166. Énallage : "l'échange d'un temps, d'un nombre, ou d'une personne, contre un autre temps, un autre nombre, ou une autre personne". A felcserélés azt jelenti, hogy egy személy vagy idő helyett egy másik személyt, időt használunk.

Herschberg-Pierrot (1993). p. 43. idézi Fontanier (1968). Les Figures du discours, Paris, Flammarion, p. 293.

${ }^{493}$ Sarraute (1956). L'ère du soupçon, p. 128.
} 
mint azok a nagy müvek, amelyeket a múlt tartogat számukra. Semmilyen alkalmazkodásra nincs szükség; erőfeszítés nélkül lépünk be a szövegvilágba, máris egész testünkkel bent találjuk magunkat; a szereplők hasonlítanak ránk vagy hasonlítanak az ismerőseinkre. [...] Úgy úszkálunk életük sodrásában, mint hal a vízben." 494

Olyan "posztmodern" szöveg jön létre, amelyben az olvasás és az írás folyamata egymásba olvad, egymásba fonódik, szüntelen szerepcserében nyer életet: a szöveg úgy jelenik meg, mint egyfajta reverzibilis körforgás, egy olvasói-írói közös tér, ahol az írás olvassa önmagát és az olvasás írja önmagát és beírja magát az írásba. Ez a „gyanakvásra” termett írásmód tehát megvalósítja az alkotó és a befogadó fúzióját: az alkotó szövege az olvasó szemszögéből önvizsgálattá válik. Írás,- illetve alkotástechnikailag az ezt a fúziót megvalósító közös sáv a szómögöttes.

Maradva a „vizes” képeknél a szómögöttes a felcserélés alakzatának segítségével úszik be a képbe: a szerző felcseréli az ők, „olvasó”, „közönség”, „kritikusok” megnevezéseket és többes szám harmadik személyü alanyokat az on általános névmásra, és a vele járó „mi” jelentésre, azonosulva velük, belép a világukba. Nincs kimondva, de a szöveg utalásszerűen tartalmazza, hogy a mi megszólaló itt a mimetikus szövegeket előszeretettel olvasó befogadói körrel azonosítható. Azt a beszédmódot emeli be esszéjébe itt a szerző, azt a szómögöttest, amely mintegy az efféle olvasók viselkedése és gondolkodása mögött húzódhat meg. Újfajta, kreatív megközelítésmódja tehát az esszé müfajának, hogy a szerző fikciós müveiből jól ismert, a dikció logikáját követő eljárását alkalmazza.

Erre a módszerre alapozva alkotja meg a Les Fruits d'Or-t ${ }^{495}$ melynek témája az irodalmi recepció. Főszereplője egy könyv, és az egyes fejezetek ennek különféle olvasatait adják felfeslő tropizmusok segítségével: mindahány egy-egy találkozás az adott irodalmi müvel. „Megdöbbentő, hogy a tilalom múltával az irodalmi müremekek lelkes és hüséges hívei, akik rendszerint olyan zárkózottak, komorak, érzékenyek voltak egy-egy új alkotással szemben, úgy falják ezeket a műveket, mint a legínycsiklandóbb étkeket." ${ }^{\text {496 }}$. Az irodalmi müvek és az étkezés metaforikus egymásra vetítése paratextuális módon már előreutal a Les Fruits d'or címére és világára. Mi történik, ha ezeket az arany gyümölcsöket, azaz regényeket különféle olvasótípusok számára tesszük hozzáférhetővé? Erre keres választ a regény, amely ugyanúgy szekvenciákból építkezik, mint a Tropizmusok, ám itt a szövegegységek nem

\footnotetext{
${ }^{494}$ Uo. p. 128.

495 Sarraute, Nathalie (1963). Les Fruits d'Or, Paris, Gallimard, 1963.

${ }^{496}$ Sarraute, Nathalie (1956). L’ère du soupçon, p. 128. "On est stupéfait de voir avec quelle avidité, tous les interdits étant levés, les amateurs les plus fidèles et les plus enthousiastes des chefs-d'œuvre de la littérature, ceux qui se montrent d'ordinaire, en présence d'une œuvre nouvelle, si fermés, si sévères, si délicats, dévorent ces ouvrages comme s'ils étaient la plus succulente des nourritures".
} 
számozottak, és összefüggenek. A négy első a „hivatásos” olvasók táborát idézi, a kilenc következő a naiv olvasóközönség változatait szemléli, a tizennegyedik utolsó rész az egyetlen, amelyik a tropizmikus olvasás lehetőségét veti fel: ő képes arra, hogy a könyv-szereplőt arctalanítsa, megfossza személyes kötődéseitől, a pozitív vagy negatív értékítéletektől, vagy akár attól, hogy valamiféle abszolút erkölcsiséget keressen benne. Itt jön létre az az arctalan, személytelen és jelentéstől mentes olvasat, amely közvetlen kapcsolatot feltételez az olvasó és a szöveg között, az érzet érintetlen frissességét hordozza. ${ }^{497}$.

Hogyan jut el regénye végére a szerző az arctalanítás poétikáját hordozó tropizmusolvasó megformálásáig? Egyrészt a Les Fruits d’or maga kizárja soraiból a genette-i értelemben vett diegézist, a történetmesélést ${ }^{498}$. Így már eleve a regény megszerkesztettsége leépíti a hagyományos genette-i irodalmi megnyilatkozás-sémát ${ }^{499}$ :

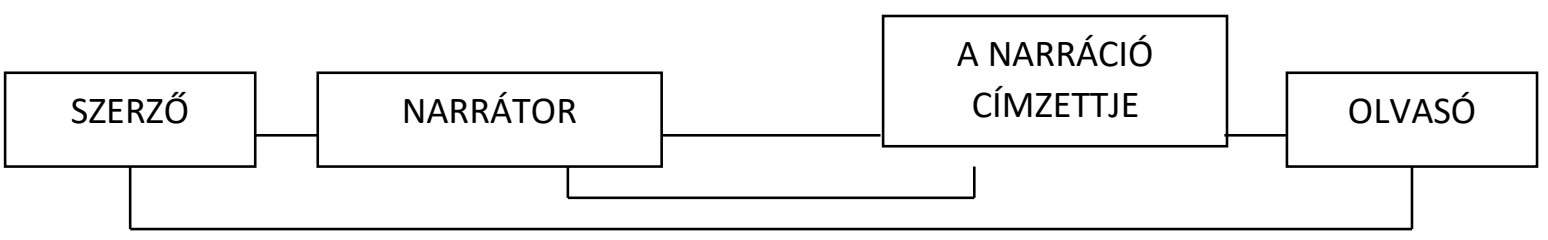

Így a narrátor szerepe nem a mesélés, hanem a regényről való beszélgetések katalizálása. Nincs tehát elbeszélő, nincs elbeszélés. De kik a szereplők? A főszereplő természetesen a szóban forgó regény, illetve szereplö-foglalatok mindazok a személyes névmással jelölt alakok, akik forgatják az említett kötetet. A fokozatos arctalanítás legfontosabb poétikai eljárásai a szövegben megfelelnek a tropizmus-képződésnek: „érzetek, amelyeket bizonyos, a tudatunk határát épphogy súroló mozgássorok hoznak létre” ${ }^{500}$. A tropizmusok fokozatos kibontakozását a szöveg csúcspontjáig, az utolsó részig Sarraute a dialógusforma és az idézés stíluseszközeivel éri el - mindkét stílusforma erősen verbális színezetü. Már a Courbetreprodukció tárgyában megkezdett beszélgetés a felütésben a művészi érték vagy értéktelenség vitájának jogosságát firtatja, és a dialógusformát később a teljes szöveg megtartja a személyes névmás-szereplők (én-ő) viszonylatában. Mivel egyáltalán nem tudjuk, vajon kik ezek a tropizmus-foglalatok, nagyrészt cotextuálisnak érezzük jelenlétüket ${ }^{501}$. Ez azt

\footnotetext{
497 Angremy, Annie (1996). Sommaire Nathalie Sarraute, ADPF, Paris, 1996, p. 24. idézi Sarraute, Nathalie (1996). "Entretien avec Geneviève Serreau" ${ }^{498}$ Genette, Gérard (1972). Figure III. Paris, Seuil, p. 72.

499 Kerbat-Orecchioni, Catherine (1999). L’Enonciation. De la subjectivité dans le langage, Paris, Armand Colin, p. 190.

500 Sarraute, Nathalie (1996). "Forme et contenu du roman" in Euvres complètes p. 1668 "les sensations que produisent certains mouvements à peine conscients"

${ }_{501}$ Kerbat-Orecchioni (1999). p. 40. Cotexte : référence relative non pas au contexte réel, mais au contexte linguistique. Cotexte : olyan referencia, amely nem a szövegkülső, hanem a szövegbelső kontextusra utal.
} 
jelenti, hogy maga a szövegtest a nyelvből építkezik és a nyelvhez tér vissza, szövegkülső referencialitása csak sejthető, beszippantja az olvasót, és mivel a szekvenciák végig fenntartják a szereplő-alakoknak ezt a fajta dialogizáló, „felnagyított jelenben” ${ }^{502}$ érvényesülő beszédmódját, az utolsó jelenetig a szöveg már-már integrálja magát az olvasót is. Az olvasók személyes névmásítása rávezet az utolsó szövegegység arctalanító mozzanatára, és feltehető, hogy gyógyírt kínál a szerző által gyanakvásnak nevezett szöveg-olvasó, író-olvasó elidegenedésre ${ }^{503}$.

\begin{abstract}
- La tête de chien. L'avez-vous vue ? - Moi je trouve ça admirable. - Je trouve ça une pure merveille. - Cette petite chose à elle toute seule...
\end{abstract}

En elle réunis... délices... communion, fusion des âmes... Je [je-il] sens que moi aussi ça me gagne... titillation exquise... ça vient, ça me possède... Incantations... Extases... Allons, tous ensemble, plus fort. Encore. Plus fort. Plus loin Moi maintenant je m'avance, je franchis toutes les bornes, (...) Le voilà. Il tombe en transes, le Dieu le possède, il se convulsionne, les yeux révulsés, l'écume aux lèvres, il se roule par terre, arrachant ses vêtements... Pour moi... il se frappe la poitrine... Pour moi, je [il ulcéré] ne crains pas de le dire... Rien audessus. Courbet est le plus grand. Shakespeare. Dernier sursaut. Il se courbe en arc de cercle : Shakespeare et Courbet. ${ }^{504}$
A kutyafej. Látta? Szerintem lenyügöző. Szerintem ez maga a csoda. - Csak maga ez a kis pici semmiség...

Egyesül benne... a lelkek Érzem, hogy engem is magával ragad... jön, a hatalmába kerít... Eksztázis... Gyerünk, mindenki, erősebben. Még. Erősebben. Én most... haladok, áthágok minden határt, (...) És itt van. Transzba esik, az Isten beléköltözik, megrázkódik, kifordul a szava, habzik a szája, hentereg a földön ahogy tépi a ruháit... Nekem... Veri a mellét... Nekem, nem félek kimondani... Semmi nem múlhatja felül. Courbet a legnagyobb. Shakespeare. Utolsót ráng. Kétrét görnyed: Shakespeare és Courbet.

A szöveg én - ő viszonylatban folyamatos átjárást hoz létre, az én-megszólalás E/3. elbeszélésre válthat vagy az E/3-as elbeszélés én-megszólalásra válthat bármikor, az idézés vagy a párbeszéd formai jegyeinek figyelmen kívül hagyásával. A kontextust teljességgel hárító, és a kotextuális referencialitást, valamint a deiktikus megnyilatkozásformákat előtérbe helyező alkotásmód valójában szómögöttes tartalmak laza láncolata. Beszélgetés a je-il és a je-ulcéré között. A közvetlen idézés és a szabad függő beszéd váltják egymást. A regényben szereplő kritikusok, illetve „tömeges regényfogyasztók”,505 azok, akikre a fejezet elején

\footnotetext{
${ }^{502}$ Sarraute, Nathalie (1996). "Roman et réalité" in CEuvres complètes p. 1655. - présent démesurément agrandi 503 U.o.

${ }^{504}$ Sarraute, Nathalie (1963). p. 9.

505 Sarraute, Nathalie (1996). "Roman et réalité" in Euvres complètes p. 1653 "la masse des lecteurs de roman"
} 
utaltunk, akik kiszívják olvasmányaik életnedvét. Ezek azonban csak „,szereplő-vázak”,506, akiknek az olvasással mindig valamilyen célja van: élvezetet, élményt szerezni, ideológiát bizonyítani, elhelyezni magunkat egy bizonyos értékrendhez képest. Nem tropizmusfoglalatok. Az utolsó részben sugallt tropizmus-olvasó vagy tropizmikus olvasó az, akire az író rábízhatja szövegét, mert kész rá, hogy annak tropizmikus mélyrétegeibe tekintsen, akárcsak az Umberto Eco-féle Olvasó ${ }^{507}$, aki „képes arra, hogy a szöveg aktualizálásában a szerző elképzelése szerint együttmüködjön, és úgy képes értelmezőként fellépni, ahogyan a szerző képes volt teremtő erejét mozgósítani." Ha a befogadó alkalmas arra, hogy arctalanságában szemlélje tárgyát, a müalkotást, akkor beszélhetünk tropizmikus olvasatról.

Oui, c'est bien le cas de le dire, nous sommes mal partis. Nous voilà réduits à un piteux état. Et seuls, se seuls, c'est à ne pas croire. J'ai beau de temps en temps... il le faut... sait-on jamais... et s'il se trouvait tout d'un coup quelqu'un qui réponde, juste une autre voix... quel soulagement! Il n'en faudrait pas plus pour qu'on se sente presque sauvés. Mais j'ai beau essayer, profitant d'un moment d'accalmie, de silence, avec fermeté pour les forcer à écouter, mais avec douceur pour ne pas les faire fuir, j'ai beau, de temps en temps lancer : «Et Les Fruits d'Or? », tout au plus un regard glisse sur moi un instant et se détourne. Mais le plus souvent ils n'entendent même pas... ${ }^{508}$.
Igen, sokkal inkább, mint valaha, ez rosszul indult. Szánalmasan végeztük. És egyedül, teljesen egyedül, ezt el se lehet hinni. Igyekezhetek néha... kell, hogy... soha nem lehet tudni... és ha hirtelen lenne valaki, aki válaszol, egy másik hang... micsoda megkönnyebbülés! Több sem kellene, hogy azt érezzük, majdnem megmenekültünk. De próbálkozhatom, amint van egy nyugalmas pillanat, a csendben, határozottan elérem náluk, hogy figyeljenek, de finoman, nehogy elmeneküljenek, időről idöre rákezdhetek újra: „És az Aranygyümölcsök?” ráadásul mintha egy pillanatra rámtapadna egy szempár, majd elfordulna. De leggyakrabban még csak nem is hallják meg...

Enallagként ${ }^{509}$ jelentkezik ismét az on általános névmás, akárcsak a Ce que voient les oiseau címü esszében, ahol már megjelent a szépirodalomról való beszéd mint téma és az on általános névmási alanyok is. Ezzel ebben a szövegben ismét ugyanazt a stílushatást éri el a szerző: az én - ő névmások mögé az előző szövegekben társíthattunk értelmezésként különféle olvasótípusokat, viszont itt, az utolsó szöveg on névmása végképp sejtelmessé teszi,

\footnotetext{
${ }^{506}$ personnage-support

507 Jouve, Vincent, La poétique du roman, Paris, Sedes, 1997. p. 114. idézi Umberto, Eco (1985). Lector in fabula, trad. fr., Paris, Grasset, 1985, p. 71. "Capable de coopérer à l'actualisation textuelle de la façon dont lui, l'auteur, le pensait et capable aussi d'agir interprétativement comme lui a agi générativement"

${ }^{508}$ Sarraute, Nathalie (1963). Les Fruits d'or, p. 151.

${ }^{509}$ Herschberg-Pierrot (1993). p. 43. idézi Fontanier (1968). Les Figures du discours, rééd., Paris, Flammarion, 1968, p. 293.

Groupe $\mu$ (1982). p. 166. Énallage: "l'échange d'un temps, d'un nombre, ou d'une personne, contre un autre temps, un autre nombre, ou une autre personne" - személy, szám, szófaj másikra cserélése.
} 
ki a szöveg beszélője. Ezt a dezidentifikációs poétikai eljárást tovább hangsúlyozza, árnyalja az egyéb személytelen szerkezetek ${ }^{510}$ bevezetésével. Az én, a $t i$ vagy $\ddot{o} n$, a $m i$ egységesítésére való szövegszerü utalások értelmezhetőek úgy, hogy a könyv és a tropizmikus olvasó mintegy eggyé válik. Ebből az egységből válik ki az én, akinek monológja feltehetően nem szómögöttes tartalmak kifejtéseként, hanem az ön hallgatóhoz, feltehetően magához a könyvhöz intézett beszédként értelmezhetőek.

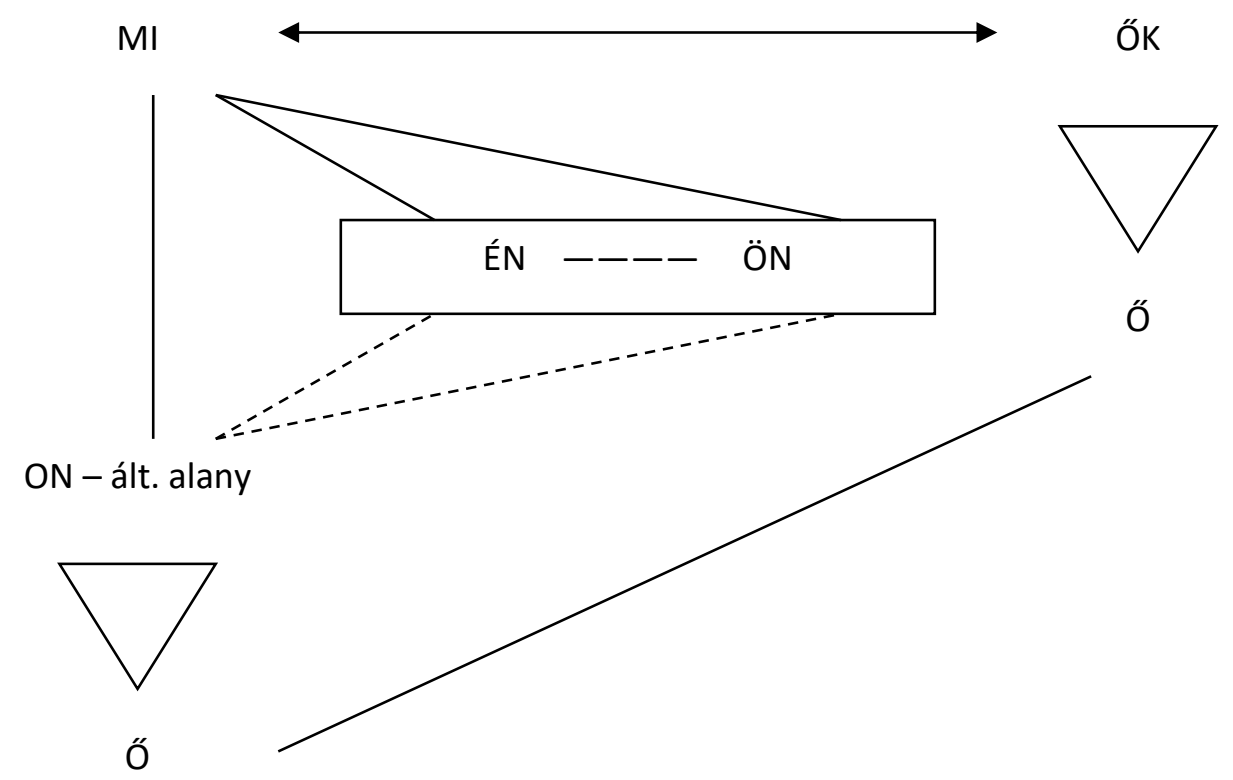

Az én és az ön egysége egyértelmü, de magányuk, elszigeteltségük az ők világától fájdalmas érzetet kelt, hiszen feltehetően a tizenhárom szövegegységen át zajló folyamat végére érve az addig a közbeszédet tematizáló alkotás elfelejtődött, már nincs a beszélgetések, viták kereszttüzében. Diszkurzív szinten ez az elidegenedés úgy jelenik meg az utolsó szekvencia felütésében, hogy számos személytelen szerkezetet használ, valamint bevezeti az on általános alanyt. Az ábra segítségével azt a feltevést ábrázoltam, hogy az olvasó és az olvasmány egységét megvalósító $m i$ enallagként on-nal való felcserélése nem értelmezhető-e úgy, hogy az én és az ön fúziója, azaz a $m i$ a személytelen szerkezetek fokozott használatával bevezetve

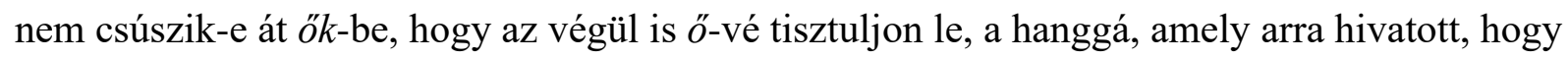
megtörje a $m i$ elszigeteltségét, magányát.

\footnotetext{
510 il faut, il arrive, il y a, il semble
} 


\begin{tabular}{|c|c|}
\hline $\begin{array}{l}\text { Mais il me semble que j'ai trop attendu. Le } \\
\text { moment est venu. Je dois essayer de } \\
\text { nouveau. Il ne faut pas laisser passer trop } \\
\text { de temps. Je vais agir avec prudence. Il y en } \\
\text { a un là, parmi eux, qui se tient un peu à } \\
\text { l'écart des autres, il a un air vacant, un air } \\
\text { disponible... « Et Les Fruits d'Or? Vous } \\
\text { vous en souvenez? » Je vais lui glisser cela } \\
\text { doucement... - «Les quoi ? C'est tout ce } \\
\text { qu'il m'a dit... Il ne faut pas s'en étonner. } \\
\text { Voilà des mois qu'il ne m'est pas arrivé de } \\
\text { rencontrer quelqu'un qui se rappelle votre } \\
\text { existence. Je n'entends jamais prononcer } \\
\text { votre nom. Mais j'ai senti qu'avec lui je } \\
\text { pouvais insister: « Entre nous, c'est un } \\
\text { fameux bouquin Tombé dans l'oubli, je n'ai } \\
\text { jamais compris pourquoi. Il faut le lire } \\
\text { absolument. » Et il m'a dit qu'il allait voir } \\
\text { ça... Je crois qu'il le fera, on peut lui faire } \\
\text { confiance... et, qui sait, si c'était la sienne, }\end{array}$ & $\begin{array}{l}\text { Úgy tünik, túl sokat vártam. Eljött a pillanat. } \\
\text { Meg kell próbálnom újra. Nem szabad, hogy } \\
\text { túl sok idő teljen el. Óvatosan fogok eljárni. } \\
\text { Van egy köztük, aki a többiektől egy kicsit } \\
\text { távolabb áll, semlegesnek tünik, kész } \\
\text { bármire... „És az Aranygyümölcsök? } \\
\text { Emlékszik rá?” Finoman adagolom neki... - } \\
\text { „Mik?" Ennyit mondott.. Nem kell ezen } \\
\text { csodálkozni. Hónapok óta nem fordult elö } \\
\text { velem, hogy találkozom valakivel, aki } \\
\text { emlékszik egyáltalán csak az ön létezésére. } \\
\text { Soha nem hallom, hogy kiejtenék a nevét. } \\
\text { De éreztem, hogy vele kapcsolatban lehetek } \\
\text { határozottabb: „Köztünk szólva, ez egy } \\
\text { kivételes olvasmány. Elfeledett, soha nem } \\
\text { értettem, miért. Mindenképpen el kell } \\
\text { olvasni.” És azt mondta, hogy majd } \\
\text { megnézi... Azt hiszem, tényleg megteszi, } \\
\text { megbízhatunk benne... és ki tudja, talán az } \\
\text { övé az a másik hang? }\end{array}$ \\
\hline
\end{tabular}

Talán a tropizmikus olvasó lehetne a tökéletes olvasó? A regény szövegzárlata ezt megkérdőjelezi, hiszen Barthes szavaival élve az olvasás szeparált, tiltott tevékenység ${ }^{512}$, a szövegzárlat pedig világosan utal az árulás lehetőségére, amikor az olvasó én kapcsolatot kereshet a tömeg-olvasóval. A regényszöveg két különböző irányból is dekonstruálja az arcot. Egyrészt a kotextualitás irányából, hiszen Sarraute-nak ez az egyik leginkább kontextusából kiragadott, belterjes szövege. Másrészt a megjelenített beszélők irányából, hiszen csak személyes névmások szerepelnek a személytelen szerkezeteken kívül, amelyeknek összefüggő, de bonyolult hálózata csupán arctalanságában megragadható.

\section{VII.4. Az önéletírás főszereplőjének dekonstrukciója, az én feloldódása a szöveg makrostrukturális szintű szerkezeteiben - Gyerekkor}

Barthes „második nyelvészetnek” nevezi azt az elemzésmódot, amely a diskurzust ${ }^{513}$ szemlélve a megnyilatkozásokat a szöveg, a beszédhelyzet, a kontextus részeként értelmezi. Az elbeszélés, a szövegformálás logikája, a szövegegészre érvényes formális, nyelvi

\footnotetext{
${ }^{511}$ Sarraute, Nathalie (1963). Les Fruits d'or, p. 156.

512 Barthes, Roland (1984). "Sur la lecture" in Essais critiques IV. Le bruissement de la langue, Paris, Seuil, p. 43.

513 Groupe $\mu$ (1982) p. 158. idézi Barthes, Roland (1966). "Introduction à l'analyse structurale du récit" in Communications, $\mathrm{n}^{\circ}$ 8. 1966. p. 3.
} 
sajátosságok vizsgálata segítségével igyekszem az önéletírás főszereplöjének stilisztikai megformálását körüljárni: a dialógusforma, az időperspektíva, az idézés változatainak elemzésével. A narrációt érintő stíluseszközöket, a szövegészre jellemző nyelvi elemeket vizsgáljuk $^{514}$ az elbeszélés makrostrukturális szintjén ${ }^{515}$.

\section{4. 1. Párbeszédes forma}

$\mathrm{Az}$ önéletírás főszereplöjének dekonstrukciója a beszédhelyzet dialogikusságában keresendő. Az önéletírás nehézségeit kívánja úgy feloldani a szerző ${ }^{516}$, hogy ugyanakkor nyilvánvalóvá teszi lehetetlenségét, erőfeszitéssé, dadogássá stilizálja. A dialógusforma veszi el a diegézis ${ }^{517}$ élét, fosztja meg elsődlegességétől. Kik ennek a párbeszédnek a résztvevői? Ducrot fogalmait vezetjük be: a „beszélő mint olyan”518 (beszélő-B) és „,a beszélő mint a világ része" ${ }^{519}$ (beszélő- $\beta$ ). A klasszikus önéletírás esetében az író két énje egybeesik. Vegyük Rousseau ${ }^{520}$ példáját: a beszélő- $\beta$ hibáit a lehető legőszintébben idézi fel, tárja fel a Vallomások, s ez a tény a beszélő-B őszinteségére hivatott rámutatni. Rousseau esetében ezek az eltérő szerepek egy személyben lakoznak abból a célból, hogy „,bemutasson egy embert a

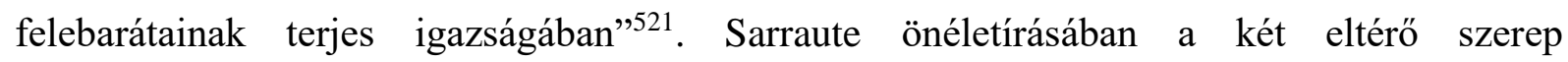
szereposztásban, párbeszédben jelentkezik a szöveg szintjén, a beszélő-B [narrátor-B (NB a továbbiakban)] és a beszélő- $\beta$ [narrátor- $\beta$ (N) ] az énelbeszélő két arca, és más-más szerepet tölt be a szövegegészen belül. A beszélö fogalma helyett a narrátor fogalmát használjuk, mert az önéletrajzi regényben az énelbeszélő két arca, vetülete közötti párbeszéd nem az ábrázolás célja, hanem eszköze. Az önéletírás célja a rövid emlékfoszlányok kimerevítése, az írás örök jelenébe emelése, ennek kapcsán az elbeszélők párbeszéde csupán az elmondás, a visszaemlékezés és a felidézés nehézségeit hivatott biztosítani.

\footnotetext{
514 Groupe $\mu(1982)$

515 Schaeffer (1997)

${ }^{516}$ Herschberg-Pierrot (1993) p. 51. idézi Lejeune, Philippe ( ). Le pacte autobiographique "Récit rétrospectif en prose qu'une personne réelle fait de sa propre existence"

517 Uo. idézi Genette (1972). p. 72. "Diégèse est synonyme d'histoire au sens de 'signifié ou contenu narratif', par contraste avec le récit, qui désigne 'le signifiant, énoncé, discours ou texte narratif' lui-même". / A diegézis a történet rokon értelmủ szava tartalom vagy jelölt értelemben, ellentétben az elbeszéléssel, amely azt jelenti, hogy jelölö, megnyilatkozás, diskurzus, azaz maga az elbeszélö szöveg.

${ }^{518}$ Maingueneau (1993) p. 76. 'locuteur en tant que tel' - locuteur-L

Ducrot-Todorov (1972). Dictionnaire encyclopédique des sciences du langage; Beszélőn a megnyilatkozás alanyát értjük, a kommunikációban a megszólalót. A beszélő kérdésköre érinti a polifónia kérdéskörét: a müvészi szövegen belül számos megnyilatkozásréteg deríthető fel: a szöveget fizikálisan létrehozó író, a szöveg beszélőjeként tételeződő én, és az egyes megjelenített beszédhelyzetekben a beszélők.

${ }^{519}$ Uo. p. 80. idézi Ducrot (1984). Le dire et le dit 'locuteur en tant qu'être du monde' - locuteur- $\lambda$

${ }^{520}$ Uo. p. $81-82$.

${ }^{521}$ Uo. p. 82. idézi Rousseau: Confessions "montrer à ses semblables un homme dans toute la vérité de la nature"
} 
A NB, az elbeszélö mint olyan szerepe, hogy tényleges keretet adjon az önéletrajznak, ám ebben folyamatosan ellehetetlenül, illetve nevetségessé válik. Ráadásul a szót sem ő viszi, hanem a párbeszéd másik megszólalója, az alternatív elbeszélő $\mathrm{N} \beta$, az elbeszélő mint a világ része. Ö partnerének teljes ellentéte: nem foglalkozik a dátumokkal, nem kívánja megnevezni a dolgokat, hanem úgy mutat be mindent, ahogyan érzékszerveivel közvetlenül felfogható, nem kíván állást foglalni és nem kíván hatást gyakorolni. Ezért gondolom, hogy a két elbeszélő disszociációja történik és nem a két beszélőé, mert nem a beszélgetésen van itt a hangsúly, hanem a visszaemlékezés kétféle felfogásának ábrázolásán, az elbeszélés nehézségeinek hangsúlyozásán. Ezért is narrátornak, elbeszélőnek és nem beszélőnek nevezem őket.

\begin{tabular}{|c|c|}
\hline A NB szerepei & Idézetek \\
\hline N $\beta$-t segíti a visszaemlékezésben & $\begin{array}{l}\text { „te kezdeményezted, hogy meséljek, egy } \\
\text { ideje te indítasz erre” } 522\end{array}$ \\
\hline ragaszkodik a dátumokhoz & $\begin{array}{l}\text { „Egészen pontosan nyolc és fél év, } 1909 \\
\text { februárjában volt” } 523\end{array}$ \\
\hline $\begin{array}{l}\text { fontos számára, hogy nevén nevezze a } \\
\text { dolgokat és a személyeket }\end{array}$ & $\begin{array}{l}\text { „Egy kicsit később lepett meg az iránta } \\
\text { érzett nagy szerelem (Napóleon iránt)” } 524\end{array}$ \\
\hline $\begin{array}{l}\text { a pontos kifejezések használatát, a tér-idő- } \\
\text { koordináták megadását célozza }\end{array}$ & „Légy pontos...,525 \\
\hline már-már akadékoskodó & $\begin{array}{l}\text { „Biztos, hogy ez a kép a Max és Móricban } \\
\text { található? Nem kellene ellenőrizni?” } 526\end{array}$ \\
\hline $\begin{array}{l}\text { fontoskodó mondatokkal közbevág, kérdő } \\
\text { modalitás, modifikátorok jellemzik a } \\
\text { mondatait }\end{array}$ & $\begin{array}{l}\text { „Nem igazán hittél benne?” } 527 \\
\text { „Talán a rossz szeme miatt volt...”528 }\end{array}$ \\
\hline $\begin{array}{l}\text { utal a párhuzamos elbeszélővel való } \\
\text { egységére }\end{array}$ & $\begin{array}{l}\text { „De. Egészen közel maradok hozzád, tudod } \\
\text { jól”529 }\end{array}$ \\
\hline $\begin{array}{l}\text { mindezt többször személytelen vagy többes } \\
\text { szám első személyü szerkezetekkel }\end{array}$ & $\begin{array}{l}\text { „Kárhoztatás, } \quad \text { rosszallás... } \\
\text { kimondani... megvetés.” } 530 \\
\text { „Ugyanakkor } \quad \text { beszélnünk }\end{array}$ \\
\hline
\end{tabular}

\footnotetext{
${ }^{522}$ Sarraute (1995). "c'est de toi que me vient l'impulsion, depuis un moment déjà tu me pousses..." p. 9.

${ }^{523}$ Uo. p. 249. "- Huit ans et demi exactement, c'était en février 1909."

${ }^{524}$ Uo. p. 243. "-C C'est un peu plus tard que t'est venu ce grand amour pour lui [Napoléon Bonaparte]"

${ }^{525}$ Uo. p. 38. „Sois juste!...”

${ }^{526}$ Uo. p. 48. „Est-il certain que cette image se trouve dans Max et Moritz ? Ne vaudrait-il pas mieux le vérifier?"

527 Uo. p. $85 .$, ,Tu n’y croyais pas vraiment ?”

${ }^{528}$ Uo. p. 94. „C'était peut-être sa mauvaise vue...”

${ }^{529}$ Uo. p. 78. „Si. Je reste tout près, tu le sais bien.”

${ }^{530}$ Uo. p. 127. „De la rancune, de la réprobation... osons le dire... du mépris.”
} 


\begin{tabular}{|l|l|}
\hline & $\begin{array}{l}\text { egymással... Mit tehettünk egyebet, milyen } \\
\text { más módja lehetett volna az egymásra } \\
\text { találásnak?" } 531\end{array}$ \\
\hline
\end{tabular}

\begin{tabular}{|l|l|}
\hline $\mathrm{N} \beta$ szerepei & \\
\hline megkérdőjelezi a fogalmakat & „Ez szerelem volt?”532 \\
\hline $\begin{array}{l}\text { megosztja a megszólalással kapcsolatos } \\
\text { ellenérzéseit, kétségeit }\end{array}$ & „Túl messzire mész”533 \\
\hline
\end{tabular}

Különleges stílushatású az édesanyáról való beszédmódjuk elkülöníthetősége.

\begin{tabular}{|c|c|c|c|}
\hline & NB az édesanyáról & $\mathrm{N} \beta$ az édesanyáról & \\
\hline $\begin{array}{l}\text { „Átkarolod édesanyád } \\
\text { szoknyáját, ő pedig } \\
\text { elhúzódik."534 }\end{array}$ & $\begin{array}{l}\text { konkrét tartalmak, } \\
\text { „anyád”, } \\
\text { „édesanyád” E/2 }\end{array}$ & $\begin{array}{l}\text { általánosító } \\
\text { tartalmak „,anyu” }\end{array}$ & $\begin{array}{l}\text { „anyunál” } 535 \text { „De } \\
\text { nézd... anyu és } \\
\text { Kolja } \\
\text { beszélget..."536 }\end{array}$ \\
\hline
\end{tabular}

Az énelbeszélő a párbeszédes forma és az említett stílusdifferenciák ellenére egységet alkot, erre utal a mindkettejük szövegében fellelhető irónia. Az ironikus ${ }^{537}$ stílus a retorikusok szerint egyfajta ellenmondat, míg a stiliszták a polifónia fogalmához kapcsolják. Olyan idézet, amelynek segítségével a beszélő hallat egy másik hangot a sajátján kívül, amelyért nem vállal felelősséget és abszurdnak tünteti fel. N $\beta$ iróniával illeti a klasszikus önéletírásokat, amelyeknek célja a szép emlékek felidézése vagy a megható gyerekkor utólagos felépítése, vagy akár a gonosz mostoha felléptetésével egyfajta érzelmi hatáskeltés.

\begin{tabular}{|l|l|}
\hline NB ironikus beszédmódja & \\
\hline ironizál a „szép gyerekkori emlékeken” & $\begin{array}{l}\text { „A helyet hová utunk vezet, azt, ami ott vár } \\
\text { rám (Ivanovoban), jellemzi mindaz, ami } \\
\text {,szép gyerekkori emléknek” minősül ; azok, } \\
\text { akiknek ilyenjük van, általában némi }\end{array}$ \\
\hline
\end{tabular}

\footnotetext{
531 „Et pourtant il fallait se parler... Que pouvait-on faire d'autre, quel autre moyen y avait-il de se retrouver ?” U.o. p. 252-253.

532 Uo. p. 243. „Était-ce de l'amour?”

${ }^{533}$ Uo. „Non, tu vas trop loin..” in U.o.

${ }^{534}$ Uo. ,tu enserres de tes bras la jupe de ta mère et elle se dégage...” in U.o.

${ }^{535}$ Uo. p. 108. „Ou alors chez maman...” in U.o. p. 108.

536 Uo. p. 75. „Mais regarde... maman et Kolia discutent” in U.o. p. 75.

${ }^{537}$ Maingueneau (1993) p. 83-89. ; Herschberg-Pierrot (1993) Chapitre 8.
} 


\begin{tabular}{|c|c|}
\hline & $\begin{array}{l}\text { büszkeséggel tárulkoznak fel mások előtt.” } \\
538\end{array}$ \\
\hline $\begin{array}{l}\text { Az elhagyott gyermek klasszikus } \\
\text { szenvedéstörténetén való ironizálás }\end{array}$ & $\begin{array}{lccr}\text { „Egészen az, amit } & \text { a gonosz } & \text { mostoha } \\
\text { válaszolhatott } & \text { volna } & \text { szegény } \\
\text { Hamupipőkének. } & \text { Ez } & \text { késztetett } \\
\text { megtorpanásra..." } & & \end{array}$ \\
\hline szabad függő beszéd & $\begin{array}{l}\text { „És ez a düh, érezhető volt, hogy nem } \\
\text { igazán Lili ellen irányul, hanem valami } \\
\text { ellen, ami felette állt.... erre irányította Vera } \\
\text { azt az eltökélt, rebbenéstelen tekintetet... a } \\
\text { sorsra, amelyet mindenáron le akart } \\
\text { győzni... ellensúlyozná... és még többet is } \\
\text { tenne, mint hogy kiegyenlítené mindazt, } \\
\text { amit megtilt a gyerekének, mindenáron } \\
\text { átformálná a legjobb, a leginkább irigylésre } \\
\text { méltó sorssá.”540 }\end{array}$ \\
\hline
\end{tabular}

\begin{tabular}{|l|l|}
\hline N $\beta$ ironikus beszédmódja & \\
\hline $\begin{array}{l}\text { inkább az emlékek elbeszélésének módjához } \\
\text { köthetö, nem önironikus }\end{array}$ & $\begin{array}{l}\text { „Egymás mellett lépkedünk a nagy komor } \\
\text { sugárúton. Pierre nagyon hasonlít az apjára, } \\
\text { csak kissé idősebbnek hat nála.” }\end{array}$ \\
\hline
\end{tabular}

A stíluskülönbséget mutató énelbeszélők párbeszédének fenntartása időnkénti fúziójuk ellenére is úgy értelmezhető, hogy a valóságba vetett énelbeszélő nem kívánja a hagyományos múltelbeszélés felelősségét felvállalni. Ez a beszélö- $\beta$, hogy narrátor- $\beta$-vá váljon, kivetíti megkettőzött énjének másik felét, a beszélő-B-t, aki így narrátor-B-vé válik. A központi szereplő a gyermek, s a két elbeszélő az oltár két szárnya, nincs semmi magányosabb az ő párbeszédüknél ${ }^{542}$.

\footnotetext{
${ }^{538}$ Sarraute (1995). p. 31. „Ce vers quoi nous allons, ce qui m'attend là-bas [à Ivanovo], possède toutes les qualités qui font de «beaux souvenirs d'enfance »... de ceux que leurs possesseurs exhibent d'ordinaire avec une certaine nuance de fierté."

${ }^{539}$ Uo. p. 130. „Tout à fait ce que la méchante marâtre aurait pu répondre à la pauvre Cendrillon. C'est ce qui t'a fait hésiter..."

${ }^{540}$ Uo. p. 145. „Et cette fureur, on sentait qu'elle n'était pas vraiment dirigée contre Lili, mais contre quelque chose qui était au-delà d'elle... c'est sur cela que Véra fixait ce regard obstiné, implacable... sur un destin qu'elle voulait vaincre à tout prix... elle compenserait, elle ferait plus encore que compenser tout ce qu'il refuserait à son enfant, elle le transformerait coûte que coûte pour en faire le meilleur, le plus enviable destin du monde."

${ }^{541}$ Uo. p. 138. „Nous marchons côte à côte dans la grande avenue morne. Pierre ressemble beaucoup à son père mais il paraît plus vieux que lui."

${ }^{542}$ Bompiani (2000) p. 49-50.
} 


\section{VI.4.2. Idöszerkezet, idöstruktúrák, igeidök és a két énelbeszélö szövegszerü megjelenésének összefüggései}

Az idővonatkozás a narrátor személyén kívül az önéletírás egyik leginkább jellemző vonása. Az önéletírót nem csak az foglalkoztatja, hogy mi történt a múltban, hanem az emlékezés, a múló idő objektivitása és szubjektivitása, valamint a múló idő építő és romboló jellege is. A két különböző időaspektus ${ }^{543}$, azaz időfelfogás, az imperfektív és a perfektív közül a szöveg nélkülözi a perfektivitást ${ }^{544}$. Ez azt jelenti, hogy a jelen és a franciában az egyik múltbeli időszemléletet képviselö imparfait adja a szöveg időbeliségét, míg a múltbeli cselekményt elbeszélő regények általános idősíkja, a perfektivitást kiteljesítő passé simple teljesen hiányzik a szövegböl. Ritkán passé composé és plus-que-parfait alakokat találunk. A klasszikus múlt idejű lineáris elbeszélésmód („regénybeli”) szembeállítja a temps du discours et temps de l'histoire ${ }^{545}$ a diskurzus és a történet idejét: a perfektív aspektusú igék leginkább a történet idejeként jelentkeznek, a Gyerekkorban a diskurzus időaspektusait felvonultató jelen, jövő, múlt (imparfait, passé composé, le plus-que-parfait) szerepel. A szerző célja tehát itt nem a történetmesélés ; azaz az énelbeszélővel összefüggésben nem annak múlteseményeit kívánja időrendi sorrendben feleleveníteni, hanem a hozzá kapcsolódó történetfoszlányokat, töredékeket, egymásra nem épülö és időben sem feltétlenül egymást követő beszédhelyzeteket elevenít fel. Így válik elsődlegessé az időaspektusok közül az imperfektivitás, a beszéd, a megszólalás, a diskurzus elsődlegességének vonatkozásában.

Mindez az énelbeszélő két vonatkozása közötti párbeszéd viszonylatában a következőképpen jelentkezik. A megnyilatkozás jelenideje a NB (az elbeszélő mint olyan) és a N $\beta$ (a létbe vetett elbeszélö) párbeszédének ideje. A NB mondandója vagy a múltra vonatkozik (passé composé, imprtfait) vagy a megnyilatkozás jelenére (jelen). A N $\beta$ beszédének idővonatkozásai összetettebbek : használja a jelent, ám ennek a jelennek kettős

\footnotetext{
${ }^{543}$ Maingueneau (1993). p. 33-34. "Az aspektus a megnyilatkozás alanyának szemlélete egy adott eseménysor időbeli lefolyásának módjáról." „L’aspect constitue une information sur la manière dont le sujet énonciateur envisage le déroulement d'un procès, son mode de manifestation dans le temps. Ennek az aspektusnak a változatai a perfektív (passé simple) és az imperfektív (imparfait), valamint a befejezett és a folyamatos időaspektusok. Pl. Je marchais quand il est arrivé. J'ai mangé puis j'ai pris mon thé. Sétáltam, amikor megérkezett. Ettem, majd megittam a teámat.

544 Az ige perfektuális szemlélete cselekvéssorban gondolkodik, és azon belül az egyes cselekményeket, cselekvéseket végességükben láttatja, míg az imparfait a lezajlás folyamatára koncentrál.

545 Ducrot-Todorov (1972) p. 399. idézi Benveniste terminusát : Diskurzus és történet a narráció két vetülete. "Diskurzusnak minősül minden olyan írott vagy szóbeli megnyilatkozás, amely a megnyilatkozás pillanatához, jelenidejéhez köthető". "Relève du discours toute énonciation écrite ou orale qui est rapportée à son instance d'énonciation."

Maingueneau (1993) p. 37. "Ezzel szemben a történet egy narratív eljárás a nyelvhasználatunkban, amely során a a mesélő és az, amit elmesél, egymástól némileg függetleníthető." "Le récit par contre un usage narratif de la langue dans lequel l'histoire est plus ou moins détachée de son énonciateur."
} 
használati értéke van: a megnyilatkozás jelenére is utalhat, ugyanakkor a múltat is helyettesíti, emlékeket idéz. Ez is mutatja a létbe vetett elbeszélő célját, hogy ne történetként elmesélhetően ragadja meg a múltat, hanem az akkori a jelenlét újraélését segítse elő elbeszélő és olvasó számára egyaránt. „Nein, das tust du nicht”. „Nem, ezt fejezd be”- e szavak olyan alakot öltenek, amely szinte elenyészik az időben... csak a jelenlét marad.” ${ }^{546}$. A jelenidő stílusértéke itt a múltnak az írás jelenidejében (szertartásában) érvényesülö jelenidejűsége, megidézett jelenlét. A beszélő folyamatos kapcsolatban van mind a múltbeli, mind a jelenbeli beszédhelyzettel.

A N $\beta$ által leggyakrabban használt igeidő a jelenidő - használatának két eltérő aspektusára a deiktikus nyelvi elemekből következtethetünk ${ }^{547}$.

„Egy széken ül mögöttem és régi altatódalt énekel... mély és bizonytalan hangja mintha kissé rekedtes volna... nincs jó hangja, és sutasága miatt van a dúdolásában valami méginkább megindító... ma is olyannyira életszerüen hallom mindezt, hogy vele tudom zümmögni, és bevallom, néha meg is teszem" "548.

A jelenidejü szövegrészlet az igeidő mindkét vonatkozását bemutatja: előbb a múlt jelenidejü idézését, majd a „ma is” kifejezéstől a két narrátor közti párbeszéd jelenét is. Az idézet első felében az aorisztikus jelent használja a szerzö ${ }^{549}$ : pontosan leírja a szereplők térbeli elhelyezkedését (,széken, mögöttem”), illetve a történetmeséléshez elengedhetetlen én, te deikszistől eltérő én, ő személyes névmások használata. Később a szövegrész visszakanyarodik a megszólalás jelenére. Ennek a másik idősíknak a deixise nem térbeli, hanem időbeli vonatkozásokat emel ki: „ma is”, továbbá a „bevallom” ige szemantikája azt sugallja, hogy a megszólalást felvállaló én számít a szavait befogadó te jelenlétére, tehát a megszólaló visszalép a narrátorárnnyal való párbeszéde jelenére. Megfigyelhető ugyanakkor a jelenidő „,nondeiktikus” használata: összeköti a két idősík beszélőjét, azonosítja személyüket.

\footnotetext{
${ }^{546}$ Sarraute (1995). p. 10. "Nein, das tust du nicht." "Non, tu ne feras pas ça..." "ces paroles viennent d'une forme que le temps a presque effacée... il ne reste qu'une présence..."

${ }^{547}$ Maingueneau (1993). p. 3-6. "A deiktikus nyelvi elemek feladata, hogy elhelyezzék a megnyilatkozást az adott beszédhelyzetben. Ismerünk személy-, hely- és idődeixist - én, te, Pierre ; a folyó mellett, itt ; illetve most, tegnap" "Les embrayeurs (traduction de l'anglais shifter) ont pour fonction l'articulation de l'énoncé sur la situation d'énonciation. Les indicateurs spatiaux (à côté de la rivière, ici), les indicateurs de temps (maintenant, hier) et les personnes (je, tu, Pierre)."

548 Sarraute (1995). p. 52-53. "Il [son père] est assis sur une chaise derrière moi et il me chante une vieille berceuse... sa voix basse et incertaine, comme un peu éraillée... il ne sait pas bien chanter et cette maladresse donne à ce qu'il chante quelque chose d'encore plus touchant... je l'entends aujourd'hui si distinctement que je peux l'imiter et j'avoue que parfois cela m'arrive..."

549 Maingueneau (1993). p. 49-53. "Az aorisztikus jelenidő a mesélés, a történet jelenideje." "Le présent aoristique est un présent historique, un présent de récit. L'utilisation du présent pour raconter des histoires."
} 
A nondeiktikus jelenidőt alkalmazó szövegrészek kifejezik, hogy a tudatunkba ivódott képek jelenvalóságát szinte lehetetlen megosztani másokkal, pedig örökre tudatunkba égtek. ${ }^{550}$

A N $\beta$ ezen túlmenően a már említett imperfektív használati értékü imparfait alkalmazza legtöbbször, annak iteratív aspektusa miatt ${ }^{551}$. Ennek oka egyrészt, hogy a N $\beta$ szerepe a NB által felelevetített cselekménytöredékek hátterének sejtetése, továbbá a kérdezés és az elbizonytalanítás, nem pedig a múlttal kapcsolatos állítás. „Ami engem illet, Verától sem féltem. Tudtam, hogy nem tudok benne ingerültséget, türelmetlenséget ébreszteni. ${ }^{552}$. Itt a „féltem” és a „tudtam” igék is imparfait alakokban vannak a franciában, ami úgy értelmezhető, hogy ismétlődő tapasztalatról van szó. „Talán.... az volt a benyomásom, hogy nem volt boldog (az apja), gondterheltnek tünt nekem... volt benne valami, ami arra indított, hogy védelmezzem.. ${ }^{, 53} \mathrm{Ez}$ utóbbi idézet esetében nem ismétlődésről, inkább háttér, érzelmek festéséről van szó.

A fentieken kívül arra is van példa, hogy a jelenidő és az imparfait alakok segítségével Sarraute történetet mesél el, azaz az imparfait a cselekvő szemantikájú igéknek is az igeidejévé válik.

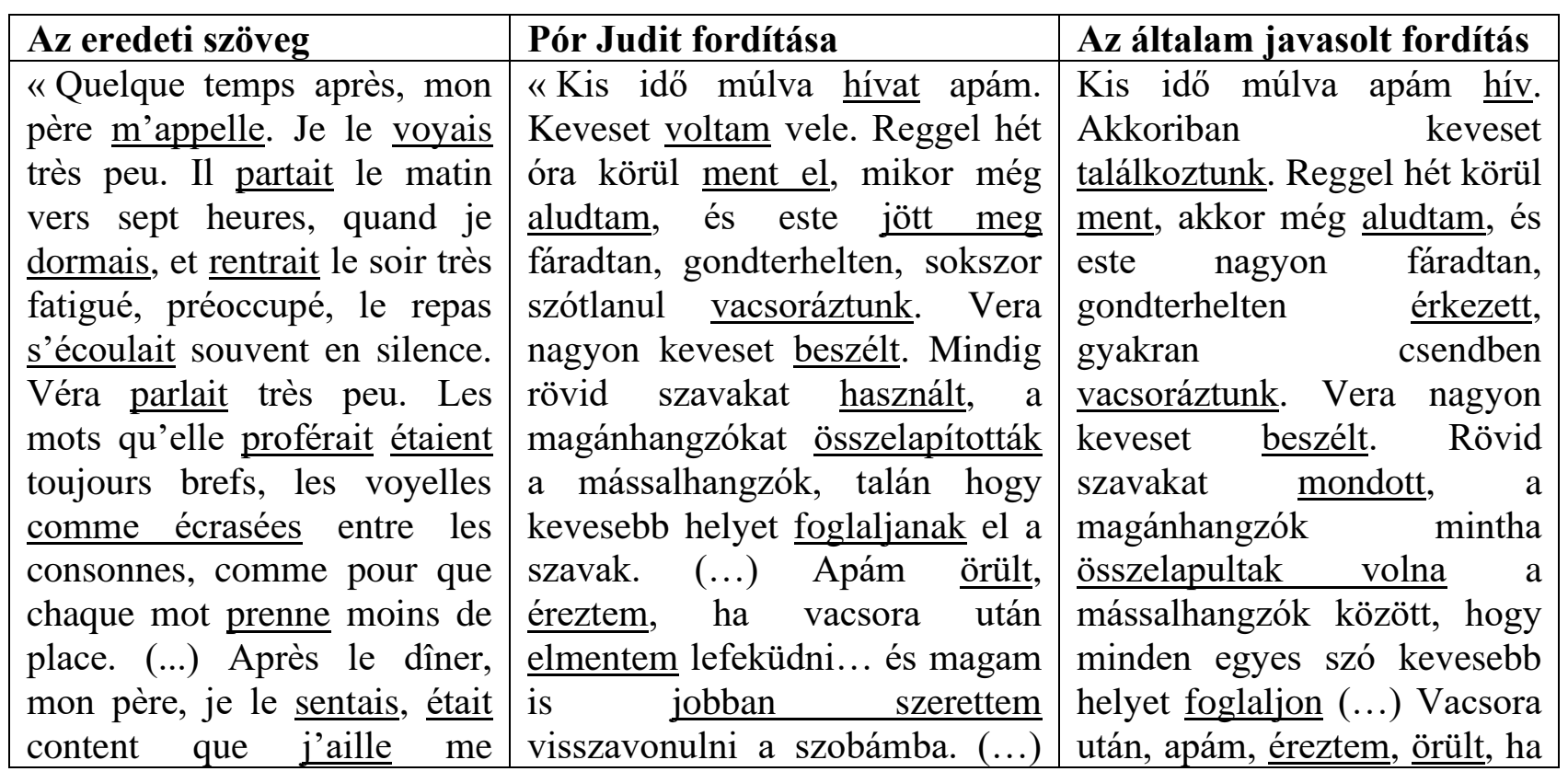

\footnotetext{
${ }^{550}$ Sarraute (1995). p. 41.

551 Maingueneau (1993). "Az iterativitás ugyanannak a folyamatnak a megismétlése" "L’itération (est) la répétition d'un même procès." P.e. : Sarraute (1995). p. 145. "— Quant à moi, je n'avais pas peur non plus de Véra. Je savais que je ne pouvais provoquer chez elle un agacement, une impatience..." Sarraute (1995). p. 157.

"- Peut-être... j'avais l'impression qu'il [son père] n'était pas heureux, il me semblait soucieux... il y avait chez lui quelque chose qui me donnait envie de le protéger..."

552 Sarraute (1995). p. 145. "- Quant à moi, je n'avais pas peur non plus de Véra. Je savais que je ne pouvais provoquer chez elle un agacement, une impatience...."

553 Sarraute (1995) p. 157. "- Peut-être... j'avais l'impression qu'il [son père] n'était pas heureux, il me semblait soucieux... il y avait chez lui quelque chose qui me donnait envie de le protéger..."
} 
coucher... et moi-même je préférais aller dans ma chambre. (...) Donc quelques jours après mon envoi de cette lettre à maman, mon père me retient après le dîner » 554
Szóval egy héttel azután, hogy elküldtem anyámnak azt a levelet, apám ott tart vacsora után" 555 aludni tértem... és én is inkább mentem a szobámba (...) Szóval néhány nappal az anyunak szóló levél feladása után apám nem enged elmenni vacsora után.

A szekvencianyitó és szekvenciazáró jelenidejű ige között közel tíz imparfait alak „meséli” a „,örténetet”. Ez a szövegegység megmutatja, hogyan sejteti a szerző az igeidőkkel az apa szavainak hátterét: a szómögöttes kedvelt igeideje az imparfait. Illetve szokásokat, rendszerességet is sejtet, bemutatja, hogyan élt a család abban az időben. Ez az iteratív igeidőhasználat, bár egyfajta monotonitást kölcsönöz a szövegnek, elősegíti a múlt és a jelen közötti átjárhatóságot, nem zárja úgy a múltba a megidézett történéseket, mint a passé composé. Kapcsolatot teremt a jelen mindkét aspektusával: a mesélés párbeszédes beszédhelyzetével ugyanúgy, mint a múltbeli történések jelenidejü mesélésével. Láthatjuk a szerző múlthasználatában, hogy amikor egy múlt idejü ige subjonctif imparfait-t vonzana, akkor is jelenidejü subjonctif-fal helyettesíti. Ez úgy értelmezhető, hogy a jelen és a múlt mintegy átjárható, szinte nincs jelenősége az idősíkok elkülönítésének.

\begin{tabular}{|l|l|l|l|l|}
\hline Az ige franciául & $\begin{array}{l}\text { aspektus } \\
\text { típusa }\end{array}$ & Az ige magyarul & aspektus & $\begin{array}{l}\text { iteratív aspektus a } \\
\text { magyarban }\end{array}$ \\
\hline je le voyais & itératív & voltam vele & perfektív & találkoztunk \\
\hline il partait & itératív & ment el & perfektív & ment \\
\hline je dormais & itératív & aludtam & iteratív & \\
\hline il rentrait & itératív & jött meg & perfektív & jött, érkezett \\
\hline $\begin{array}{l}\text { le diner } \\
\text { s'écoulait }\end{array}$ & itératív & vacsoráztunk & iteratív & \\
\hline elle parlait & itératív & beszélt & iteratív & \\
\hline je sentais & itératív & éreztem & iteratív & \\
\hline je préférais & itératív & jobban szerettem & perfektív & inkább mentem \\
\hline
\end{tabular}

Azt látjuk tehát, hogy Sarraute mintegy diegézis nélküli diskurzus létrehozásában érdekelt, és ehhez tudatosan kerüli a történetmesélésre utaló igeidőket.

A passé composé ugyanakkor, amelynek szerepe, hogy „perfektív szemléletű múltidőt alkosson, amely kapcsolatban van a jelennel és befejezett" ${ }^{556}$, egyetlen szövegegységben bár, de idézi a múltat: a 49-es szekvenciában, amelynek címe lehetne: Tiebia podbrossili. A

\footnotetext{
${ }^{554}$ Sarraute (1995) p. 114-115.

${ }^{555}$ Sarraute (1986) p. 110-111.

${ }^{556}$ Herschberg-Pierrot (1993) p.48. "joue (...) le rôle d'un accompli du présent ou d'un passé perfectif tensif, en relation avec le présent"
} 
legtöbb ige itt is imparfaitban van, de a „mondta” passé composéban, értelmezésem szerint azért, mert a mondat kimondásának tényét, egyszeriségét, visszavonhatatlanságát húzza alá ezzel a szerző.

\begin{tabular}{|c|c|c|}
\hline Az eredeti szöveg & Pór Judit fordítása & Az általam javasolt fordítás \\
\hline 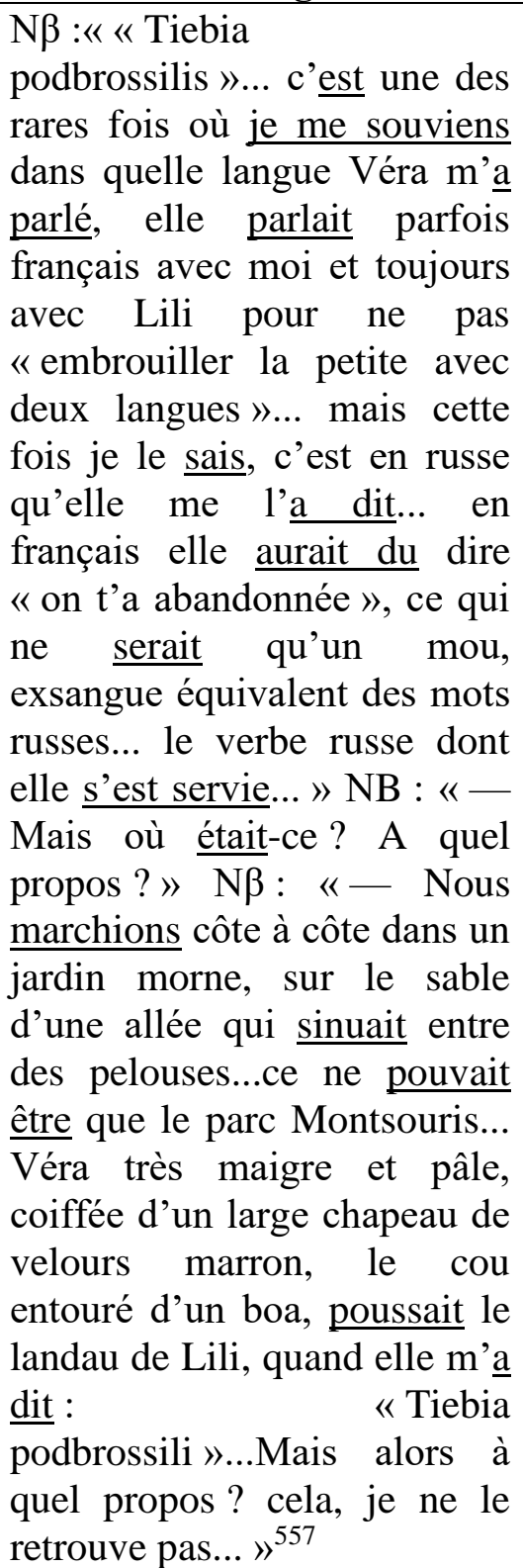 & $\begin{array}{l}\text { N } \beta \text { : „Tyebja podbroszili” ... } \\
\text { általában nemigen emlékszem rá, } \\
\text { hogy Vera mikor milyen nyelven } \\
\text { beszélt hozzám, néha velem is } \\
\text { franciául beszélt, de Lilivel } \\
\text { mindig, hogy „össze ne zavarja a } \\
\text { kislányt két nyelvvel”... de } \\
\text { ezúttal tudom, hogy ezt oroszul } \\
\text { mondta... ha franciául mondja, } \\
\text { hogy „leráztak”, az csak ernyedt, } \\
\text { vértelen mása lett volna az orosz } \\
\text { megfelelőjének... az az orosz } \\
\text { ige, amit használt... NB: Hol } \\
\text { történt, milyen alkalomból? N } \\
\text { Valami sivár parkban sétáltunk a } \\
\text { pázsitszőnyegek közt kanyargó } \\
\text { homokos sétányon... csak a } \\
\text { Montsouris-park lehetett... Vera } \\
\text { nagyon sovány volt és sápadt, a } \\
\text { fején nagy barna bársonykalap, a } \\
\text { nyaka körül szőrmeboa, a Lili } \\
\text { kocsiját tolta, mikor azt mondta: } \\
\text { „Tyebja podbroszili”... De hogy } \\
\text { milyen alkalomból? Arra nem } \\
\text { emlékszem... } 558\end{array}$ & 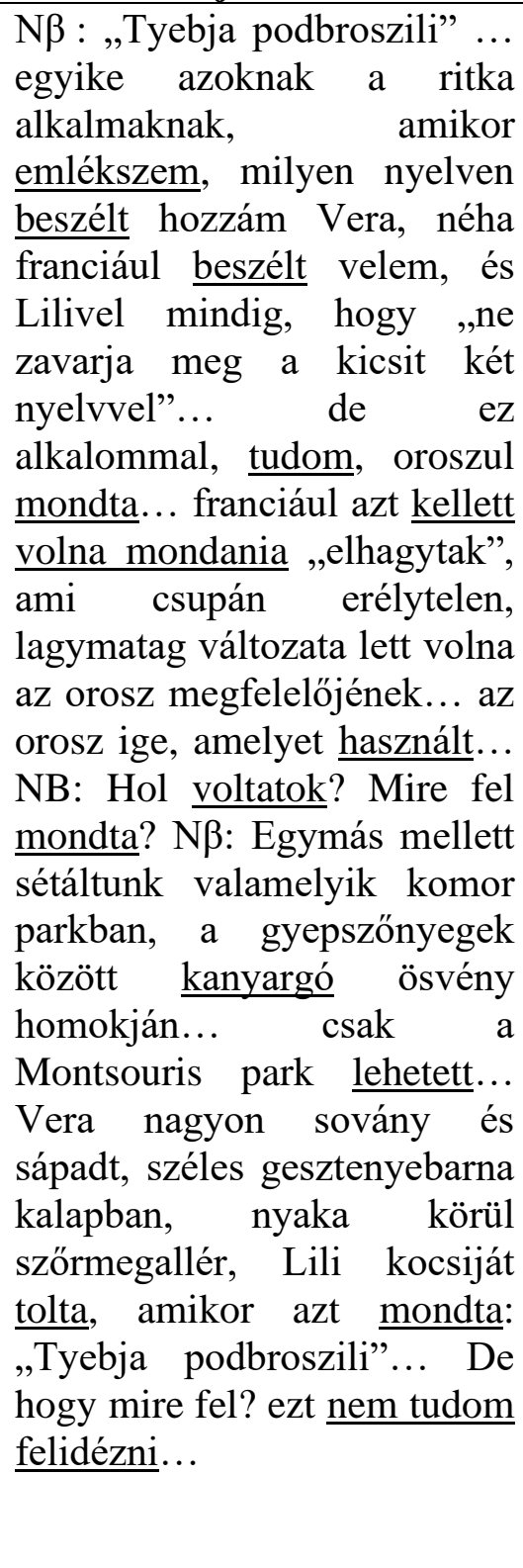 \\
\hline
\end{tabular}

Egészen a NB által feltett kérdésig az idézett szövegegység jelenidejű igéket tartalmaz. ezeknek a jelenidőknek a használati értéke a megnyilatkozással való egyidejűség. Egy imparfaitban található igét találunk, amelynek értéke iteratív, és több múlt idejű igei formát: passé composé, feltételes mód múlt idő. A Tiebia podbrossili élménye nem az emlékezés beszédhelyzetének jelenideje vonatkozásában idéződik fel, hanem ezúttal klasszikus narratív

\footnotetext{
557 Sarraute (1995) p. 182.

${ }^{558}$ Sarraute (1986) p. 173.
} 
stílusban a passé composé használatával, amely a múlt idejű történések sorának felidézésére szolgál. Az imparfait ezúttal az eseménysor hátterét festő leíró és érzelemkifejező igék ideje. Ennek a sajátos, mintegy hagyományos igeidőhasználatnak az oka, hogy az emlékfoszlányokat a szerző a jelen-imparfait időspektrumon emléktöredékként, mintegy hangulatában, jellegében megtörtént eseményként idézi. Ezúttal azonban feltehetően valóban megtörtént esemény emlékéröl van szó ${ }^{559}$, nem ismétlődő „típustörténésekről”, amelyekben inkább a felvillanó képeknek, hangoknak az akkori jelenidejűsége felidézhető. Egy részben, a parki séta jelenetben találunk imparfait alakokat a cselekvéssor igéi helyén, hiszen itt is az iterativitást helyezi előtérbe a szerző, nincs szó pontos emlékképről, hanem általában így sétáltak a nevelőanyjával. A mondás ténye van passé composéban, mert az valóban pontosan felidézhető kép.

Összefoglalóan: a Gyerekkor című önéletrajzi regényben az időhasználat fő sajátossága, hogy nem válik el jellegében a jelen és a múlt, hanem a jelen két használati értéke szerint a szerző hol deiktikus jelenidőt használ egy konkrét beszédhelyzet megjelenítése céljából, hogy nem deiktikus, szinte már-már aorisztikus jelenidőt. Az imparfait használatának két értéke, azaz a múltbeli szokások, múltbeli események hátterét adó leírások, érzelmek, hangulatok felidézése a cselekménymondás igeidejévé lép elő nagyon sok esetben. Mindez a kettős énelbeszélő vonatkozásában úgy értelmezhető, hogy meg sem kísérlik a múltjában történt események, történések, történetek konkrét felidézését, autentikus, hiteles ábrázolását. A diskurzus idővonatkozásai kerülnek előtérbe, az ezzel járó imperfektivitás a teljes szövegegységnek a szóbeliség, az éppen kimondódó hangzó szöveg érzetét kölcsönzi.

\section{VI.4.3. A Gyerekkor szereplöinek szavai mint idézés és párbeszéd}

Ahogyan az igeidőhasználat esetében, ezúttal is a diszkurzív szerveződés, a stilisztikai vonatkozások, a „második nyelvészet”560 által feltárható nyelvi jegyek vizsgálata lesz elsődleges, hogy a szereplők megszólalásai leírhatóak legyenek. A függő beszéd, az idézés, a szóbeliség szövegbeli megnyilvánulásai olyan diszkurzív eljárások, narratív technikák ${ }^{561}$, amelyek az elbeszélés szereplőinek megnyilatkozásait a makrostrukturális szint ${ }^{562}$ egészében

\footnotetext{
${ }^{559}$ Sarraute (1995). p. 107. Exemple: "Il est facile d'imaginer les plaines toutes blanches - c'était en février - à travers lesquelles nous roulions, les isbas de bois, les troncs blancs des bouleaux, les sapins sous la neige... je les voyais sûrement... mais ils se confondent avec tant d'autres images semblables. Ce qui ne se confond avec rien, c'est maman assise en face de moi"

${ }^{560}$ Groupe $\mu$ (1982). p. 158. idézi Barthes, Roland (1966). "Introduction à l'analyse structurale du récit" in Communications, $\mathrm{n}^{\circ} 8,1966$. p. 3.

${ }^{561}$ Groupe $\mu$ (1982)

562 Jean-Marie Schaeffer (1997). "La stylistique littéraire et son objet" in Littérature $\mathrm{N}^{\circ} 105,1997$
} 
jellemzik. A Gyerekkor énelbeszélőjének belső dialógusa megadja a szöveg alaphangját, verbális karakterjegyeit. A szóbeliség nyelvi jellegét erősíti az elbeszélés idődimenziójának imperfektivitása, iterativitása, valamint az a számos idézet, amelyet a szerző szó szerint emel be múltbeli emlékfoszlányként a jelen szövegtestbe. Ezáltal is nyilvánvaló, hogy az $E n^{563}$ elbeszélő nem arra tesz kísérletet, hogy újraalkossa azt az elsüllyedt világot, amelyet a múltam szóval aposztrofálhatna, hanem inkább az, hogy újraélje a felidézett párbeszédeket és hozzásegítse az olvasót ahhoz, hogy ő is úgy élje át öket, mintha a jelenben történnének. Az idézetek szerepe még az énelbeszélés polifóniájának biztosítása, az eltérő hangok beemelése.

A szó szerinti idézés ${ }^{564}$ a leginkább jellemző a szövegegészre, majd a narrátor és árnyékszemélyisége dialógus segítségével egyfajta szómögöttest, sajátos kommentárt füz ezekhez az idézetekhez. A függő beszéd hiánya arról árulkodik, hogy a szerző elítéli azt a „szokást, hogy a függő beszéd radikálisan elválasztja egymástól a dialógust és a narrációt”565. Sarraute narrációjával azt a célt szolgálja, hogy elkerülje a „bekezdések, gondolatjelek, kötőjelek és kettőspontok monoton és ügyetlen egymásutánját: mondta Jeanne, válaszolta Paul, amelyek szokás szerint szegélyezik a regénybeli dialógusokat ${ }^{566}$. A szabad függő beszéd, a „narrativzált diskurzus vagy elbeszélt megszólalás" 567 az alárendelések, időátváltások sora miatt ritka, ugyanakkor a közvetlen idézés, Genette ${ }^{568}$ terminusával „áthelyezett diskurzus” gyakori. A közvetlen idézés szerepe, hogy segítségével a múltbeli élethelyzetből mintegy transzpontálja, átemeli a beszédszituációt az írás jelenébe.

Az elhangzott beszédfoszlányok szó szerinti szövegbe emelése a leginkább eredeti és leginkább „mimetikus” ${ }^{\text {569 }}$ egyenes beszéd. Ennek értelmezése az énelbeszélőkre nézve, hogy sem a NB, sem a N $\beta$ nem vállalja fel az elbeszélés lehetőségét, csupán megidézi a múltbeli beszédhelyzetet, mintegy az írás jelenében életre írva azt. Vagy idézőjel nélkül jelentkeznek a „narrativizált” töredékekben (amelyekben azért az elbeszélés jelleg felerősödik), vagy a

\footnotetext{
${ }^{563}$ Groupe $\mu$ (1982). p. 188. "Le narrateur des journaux et des lettres ; il a une vision 'avec' le personnage. C'est une 'figure de point de vue', une 'figure de narration'" "Az újságok és a levelek elbeszélöje ; a 'szereplö nézőpontjából' láttatja a dolgokat. A 'nézőpont stíluseszköze', 'narrációs stíluseszköz'".

${ }^{564}$ Herschberg-Pierrot (1993). p. 112. "A közvetlen idézés nem csak a megnyilatkozást, hanem a beszédhelyzetet is felidézi ... (a közvetlen idézés) ezért az eredetiséget hangsúlyozza." "Le discours direct reprend non seulement un énoncé mais un acte d'énonciation. (...) [Le discours direct] renforce l'impression d'authenticité."

565 Sarraute (1956) p. 105.

566 Uo. p. 105.

${ }^{567}$ Herschberg-Pierrot (1993) p. 117.idézi Genette (1972) p.191.

${ }^{568}$ Uo., p. 117 : "A közvetlen idézés a leginkább 'mimetikus' a három diskurzustípus közül : megjeleníti az intonációt, az idézett beszéd jelölőjét átemeli, ideértve a közbevetéseket, az agrammatikus szavakat, az idegen szavakat, de nem autonom megnyilatkozás." "Le discours direct est en effet le plus 'mimétique' des trois discours : il reproduit les intonations, transmet le signifiant des paroles rapportées, y compris les interjections, les termes agrammaticaux, les mots étrangers, mais il n'est pas autonome pour autant".

${ }^{569}$ Uo. p. 112.
} 
„,nem-narrativizált” töredékek részeként (ezekben az epizódokban a tropizmus fontosabbá válik, mint az elbeszélés) idézőjelek között szerepel. Az egyik leginkább „narrativizált” epizód Vera édesanyjának látogatása a családnál. Az énelbeszélő szinte a hagyományos elbeszélői eljárásoknak megfelelően meséli el a nagymama élettörténetét. A gyermek és a nagymama beszélgetéseit idézőjelek nélkül helyezi át a narrációba. Az Én személyes névmás időnként Vera anyját, időnként az önéletrajz narrátorát jelöli és nincs a három ponton kívül, illetve időnként a gondolatjeleken kívül semmi jele annak, hogy párbeszédről van szó.

Je savais que son mari, Fiodor Tudtam, hogy férje, Fjodor Seremetyevszkij, Cheremetievski, s'était mis à boire... (...) ivásnak adta a fejét... (...) egy iszonyú il était mort d'une maladie effroyable betegségben halt meg a férje (...) Halála (...)... Après sa mort, quand je suis restée után, mikor egyedül maradtam... nagyon seule... il était très dépensier, il s'était költekező volt, tönkrement... fel kellett ruiné... il a fallu que j'élève nos quatre nevelnem a négy gyermekünket... tanítanom enfants... j'ai du enseigner, donner des kellett, órákat adtam... - Akkor azért tudsz leçons... - C'est pour ça que tu sais si ilyen jól tanítani... - Hát mit csináltam bien ?... - Que veux-tu, j'étais bien volna, kénytelen voltam... obligée... . ${ }^{570}$

Az idézőjeles forma a fenti narratív eljárásnál is gyakoribb. Natasa mamának szeretné szólítani Verát, Vera szavai idézőjelben szerepelnek, hiszen tropizmust indítanak el. „(Vera) azt feleli, hogy „,nagyon jó lesz, (mármint, hogy mamának szólítsa ezentúl), de engedélyt kell kérned rá édesanyádtól”..." ${ }^{, 511}$ Számos hasonló esetben az egymondatos egyenes idézet a verbális tropizmus szerepét tölti be: „Ha egy gyerek szereti az édesanyját, mindenkinél szebbnek látja.”572; „Férj és feleség mindig egy párton van”,573 ; „Ez nem a te

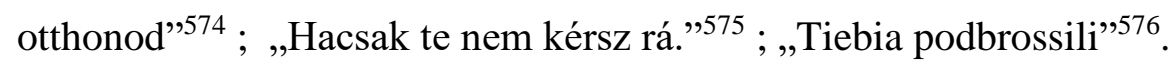

A beszéd narratív szervező elv a klasszikus narrativitás nyelvi elemei helyett. Egyenesen idézett dialogikus beszédformák, szövegbe vetített párbeszédek, amelyekhez nincs idézőjel a narrativizált epizódokban és az idézőjelek közé helyezett dialogikus formák a nem narrativizált fejezetekben még akkor is, ha a párbeszéd, a verbális interakció két személy között valamennyi jelenet döntő narratív formája marad.

Bár nem gyakran, a függő beszéd is előfordul:

\footnotetext{
${ }^{570}$ Sarraute (1995) p. 182.

${ }^{571}$ Uo. p. 209.

572 Uo., p. 92.

573 Uo., p. 70.

574 Uo., p. 126.

${ }^{575}$ Uo., p. 166.

${ }^{576}$ Uo., p. 174. Téged elhagytak.
} 
„Becsukja a füzetet, visszaadja és így szól: - Előbb a helyesírást kell megtanulni, és csak azután regényt írni" 577.

„(Adél) fekete szemével mereven nézi a felé irányított acélhegyet, és keskeny szájából ezek a szavak jönnek elö: - Szóval anyádnál nem tanítottak meg rá, hogy nem így szokás odaadni az ollót?” 578

„Vera megtorpan, nem szól... aztán azt mondja kimért, ellentmondást nem türő hangján: - Gyerekeket nem gyülöl az ember" ${ }^{\prime 579}$.

Csupa „felnőtt beszéd”, amelyek igaz, szenvedést okoznak, ám szerepük, hogy kibillentsék a gyermeket a komfortzónájából, további élete szempontjából lényeges fejlődési szakaszokat indítsanak el, és mindig önmagukban állnak, csupán az a beszédhelyzet van nagyvonalakban felidézve, amelyben elhangzottak. Nem a tropizmus részei, nem ismerjük meg szómögöttesüket.

Bompiani hatásos módon foglalja össze a verbális tropizmusok müködésmódját: a gyermek a szavak világában éli meg annak a tapasztalatát, hogy eltérés van a szavak és azon tartalmak között, amelyeket a szavak elfedni kívánnak, nem kívánnak közölni.

„Az olyannyira várt szavak (amelyek simogatták volna a föld alatti, tudatalatti mozgást, mozdulatokat), és az elhangzó szó között, amely arcul üti a felszínt. Az írás összefoglalja, magában hordozza, röviden átadja ezt az eltérést, a maga ügyének tekinti, forrásához helyezkedik." ${ }^{, 500}$.

A Gyermekkorban tehát a beszéd idézet (közvetített beszéd), ugyanakkor tropizmus, az énelbeszélő visszaemlékezik a gyermekkorában jellemző tropizmusokra, amelyek hozzásegítették, hogy „gondolatok nőjenek benne”, ugyanakkor azok a tropizmusok is megörökítődnek, amelyekkel ő igyekszik hatni a környezetére. Vagy a verbális tropizmusok azok a sokkszerü verbális hatások, amelyeket a környezetünk gyakorol ránk vagy mi gyakorlunk a környezetünkre a megszólalásokon keresztül. „Szeretsz, papa ?”581 ; „Szerintem ő szebb, mint te [az anyja]" ${ }^{582}$; „Olyan a bőröd [az anyjának] mint egy majomnak... , ${ }^{583}$; „Mondd, gyülölsz [Véra] ?"584, - ezek a verbális tropizmusok elkülöníthetők a nemverbális tropizmusoktól, amelyekről szó volt az előző oldalon: a drazsélopás ${ }^{585}$ vagy a síró Vera megvigasztalása ${ }^{586}$. Lélektani szempontból a gyerekkor az az időszaka az életnek, amikor a

\footnotetext{
${ }^{577}$ Uo, p. 80.

578 Uo., p. 153.

${ }^{579}$ Uo., p. 268.

${ }^{580}$ Bompiani (2000) p. 49.

${ }^{581}$ Sarraute (1986.) p. 53.

582 Uo. p. 95.

${ }^{583}$ Uo. p. 135.

${ }^{584}$ Uo. p. 272.

${ }^{585}$ Uo., p. 155-158.

${ }^{586}$ Uo. p. 202-206.
} 
felnőtt életvezetési stratégiák még kialakíthatók, elsajátíthatók. Hogyan viselkedjünk a pozitív és negatív hatások közepette és hogyan hassunk mi magunk is a környezetünkre. Tulajdonképpen a nem-narrativizált szövegegység középpontjában a tropizmus áll. A megjelenő párbeszéd vagy egyenes idézés a jéghegy csúcsa, reakció egy verbális vagy nonverbális hatásra, amely elindítja a tropizmus folyamatát.

„A beszélt nyelvben, a szóbeliségben tapasztalja meg a gyermek az izolációt, a távolságot a szó és aközött, amit a szó nem jelent. A hallott beszéd, kifejezés, idézet (amely érintkezik a szómögöttessel) és a hallott beszéd (amely a felszínt érinti). Az írás azon van, hogy ezt az eltérést jelezze, közvetítse." 587

\section{VI.4.4. Központozás a Gyerekkor énelbeszélöjének szövegében}

Az alábbi szövegrészletben megvizsgáljuk a ritmus (központozás) esztétikai értékét, jelentőségét. Sarraute prózanyelvének ritmikussága nem ritka a kortárs irodalomban és átmenetet képez a lírai és az epikus beszédmód között. Már Flaubert elméleti alapvetése és gyakorlati prózatechnikája hozzájárult ahhoz a XIX. században, hogy új prózai nyelv születhessen: „a prózának a vers ritmusán kell megszólalnia (miközben próza marad, nagyon is próza) "588. „Tehát nem lehet többé szabályok nélküli szövegnek tekinteni (oration soluta), hanem olyan szövegeket kell írni, amelyek legalább annyira megkomponáltak, mint a versek"589. A központozás egyszerü kis grafikai jelekből áll, ám használatuk nagyban hozzájárul a szövegek jelentésének kialakításához és ahhoz, ahogyan felolvasáskor érzékeljük őket. Az alábbi szövegrészletben ezeket a jelentésváltozatokat fogjuk megvizsgálni a vesszők és a három pontok helyének és szerepének értelmezésével. Sarraute-nál a központozás nem külső szabályrendszer alkalmazása, hanem a szöveg belső logikájának egyik vetülete, kivetülése, a gondolat érzékelhető mozzanata. Elviekben a központozásnak három különböző funkciója van: mondattani szempontból a szöveg megalkotottságának egyik alappillére, prozódiai szempontból megkönnyíti a felolvasást (hangsúlyozás, hangsúlyok, szünetek) és végül szemantikai szerepe, hogy logikailag elkülöníti a szövegrészeket, megalkotja az egyes szövegmozzanatok logikai viszonyrendszerét. Hogyan valósítja meg Sarraute a „szóbeliség” előtérbe helyezésével, hogy ez a három funkció a hagyományostól eltérő értékkel jelentkezik?

\footnotetext{
${ }^{587}$ Bompiani (2000) p. 49. „C'est dans la langue parlée, en effet, que l'enfant fait l'expérience de la coupure, de l'écart. L'écart entre le mot et ce qu'il ne veut pas dire. Entre la parole attendue (qui caresse le mouvement souterrain), et la parole entendue (qui gifle la surface). L'écriture résumera cet écart, en fera son affaire, se plaçant à sa source"

${ }^{588}$ Flaubert, Gustave, Correspondance, Gallimard; t. II, p. 229. cité par Herschberg-Pierrot (1993) p. 277.

${ }^{589}$ Herschberg-Pierrot, Anne, (1993) p. 277.
} 


\begin{tabular}{|c|c|c|}
\hline EIE & isa & \\
\hline $\begin{array}{l}\text { Pourquoi vouloir faire } \\
\text { revivre cela, sans mots qui } \\
\text { puissent parvenir à capter, à } \\
\text { retenir ne serait-ce qu'encore } \\
\text { quelques instants ce qui } \\
\text { m'est arrivé... comme } \\
\text { viennent aux petites bergères } \\
\text { les visions célestes, mais ici } \\
\text { aucune sainte apparition, pas } \\
\text { de pieuse enfant... } \\
\text { J'étais assise, encore au } \\
\text { Luxembourg, sur un banc du } \\
\text { jardin anglais, entre mon } \\
\text { père et la jeune femme qui } \\
\text { m'avait fait danser dans la } \\
\text { grande chambre claire de la } \\
\text { rue Boissonade. Il y avait, } \\
\text { posé sur le banc entre nous } \\
\text { ou sur les genoux de l'un } \\
\text { d'eux, un gros livre relié... il } \\
\text { me semble que c'étaient les } \\
\text { Contes d'Andersen. } \\
\text { Je venais d'en écouter un } \\
\text { passage... je regardais les } \\
\text { espaliers en fleurs le long du } \\
\text { petit mur de briques roses, } \\
\text { les arbres fleuris, la pelouse } \\
\text { d'un vert étincelant jonchée } \\
\text { de pâquerettes, de pétales } \\
\text { blancs et roses, le ciel, bien } \\
\text { sûr, était bleu, et l'air } \\
\text { semblait vibrer légèrement... } \\
\text { et à ce moment-là, c'est } \\
\text { venu... quelque chose } \\
\text { d'unique... qui ne reviendra } \\
\text { plus jamais de cette façon, } \\
\text { une sensation d'une telle } \\
\text { violence qu'encore } \\
\text { maintenant, après tant de } \\
\text { temps écoulé, quand, } \\
\text { amoindrie, en partie effacée } \\
\text { elle me revient, j'éprouve.... } \\
\text { mais quoi? quel mot peut } \\
\text { s'en saisir? pas le mot à } \\
\text { tout dire : «bonheur », qui } \\
\text { se présente le premier, non, }\end{array}$ & $\begin{array}{l}\text { Minek akarom teleleszten1, } \\
\text { mikor nincsenek szavak, } \\
\text { amelyek megragadhatnák, } \\
\text { tartóztathatnák, ha tovább } \\
\text { nem, hát csak még néhány } \\
\text { pillanatra azt, ami velem } \\
\text { történt... mint a kis } \\
\text { pásztorlányoknak megjelenő } \\
\text { mennyei látomások... de itt } \\
\text { se szent jelenés, se kegyes } \\
\text { gyermek... } \\
\text { Ezúttal is a Luxemboug- } \\
\text { kertben ültem a padon az } \\
\text { angolkertben apám és a fiatal } \\
\text { nő közt, aki a Boissonade } \\
\text { utcai nagy, világos szobában } \\
\text { megtáncoltatott. A padon, } \\
\text { köztünk vagy valamelyikük } \\
\text { ölében volt egy kemény } \\
\text { kötéses vastag könyv... azt } \\
\text { hiszem, Andersen meséi. }\end{array}$ & 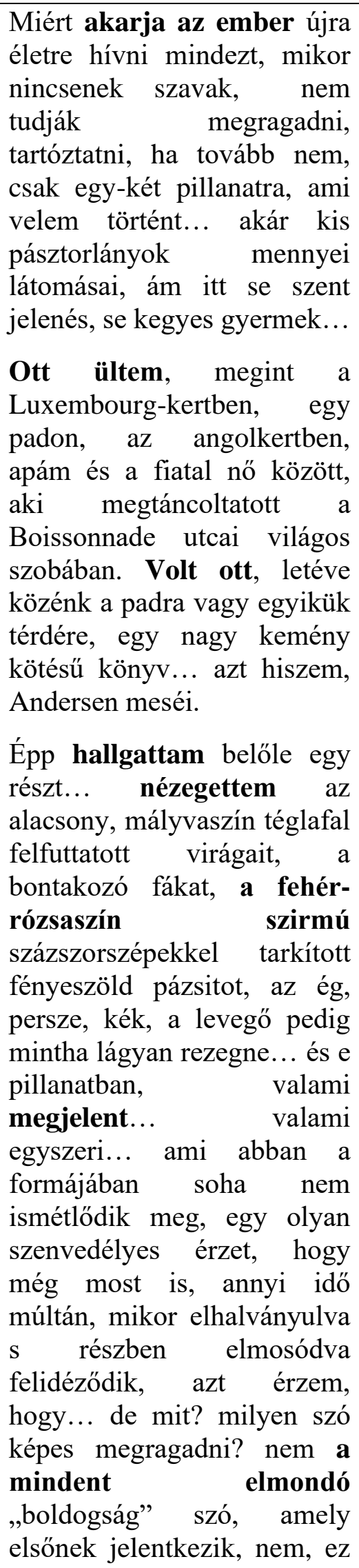 \\
\hline
\end{tabular}




\begin{tabular}{|c|c|c|}
\hline $\begin{array}{l}\text { pas lui... "félicité », } \\
\text { « exaltation », sont trop } \\
\text { laids, qu'ils n'y touchent } \\
\text { pas.... et «extase »... comme } \\
\text { devant ce mot ce qui est là se } \\
\text { rétracte... « Joie », ou, peut- } \\
\text { être... ce petit mot modeste, } \\
\text { tout simple, peut effleurer } \\
\text { sans grand danger... mais il } \\
\text { n'est pas capable de recueillir } \\
\text { ce qui m'emplit, me } \\
\text { déborde, s'épand, va se } \\
\text { perdre, se fondre dans les } \\
\text { briques roses, les espaliers en } \\
\text { fleurs, la pelouse, les pétales } \\
\text { roses et blancs, l'air qui vibre } \\
\text { parcouru de tremblements à } \\
\text { peine perceptibles, } \\
\text { d'ondes.... des ondes de vie, } \\
\text { de vie tout court, quel autre } \\
\text { mot ?... de vie à l'état pur, } \\
\text { aucune menace sur elle, } \\
\text { aucun mélange, elle atteint } \\
\text { tout à coup l'intensité la plus } \\
\text { grande qu'elle puisse jamais } \\
\text { atteindre... jamais plus cette } \\
\text { sorte d'intensité-là, pour rien, } \\
\text { parce que c'est là, parce que } \\
\text { je suis dans cela, dans le petit } \\
\text { mur rose, les fleurs des } \\
\text { espaliers, des arbres, la } \\
\text { pelouse, l'air qui vibre... je } \\
\text { suis en eux sans rien de plus, } \\
\text { rien qui ne soit à eux, rien à } \\
\text { moi.590 }\end{array}$ & $\begin{array}{l}\text { mindent megmondani, nem, } \\
\text { nem jó... az ,üdv”, a } \\
\text { „felindultság” csúnya } \\
\text { szavak, nem fejezik ki... hát } \\
\text { a „révült elragadtatás”... } \\
\text { mintha mindaz, ami benne } \\
\text { van, visszariadna ettől a } \\
\text { szótól... „Öröm”, igen, talán } \\
\text { ez... ez a kis szerény, } \\
\text { egészen egyszerü szó érhet } \\
\text { hozzá veszélytelenül... de } \\
\text { nem gyüjtheti magába } \\
\text { mindazt, ami betölt, } \\
\text { kicsordul belőlem, szétárad, } \\
\text { beleolvad, beleivódik a piros } \\
\text { téglákba, a virágzó } \\
\text { futónövényekbe, a pázsitba, a } \\
\text { rózsaszín és fehér szirmokba, } \\
\text { a rezgő levegőbe, amelyet } \\
\text { alig észrevehető remegések, } \\
\text { áramok járnak át... az élet } \\
\text { áramai, rövden: az élet, } \\
\text { minek ide más szó?... ez } \\
\text { maga az érintetlen élet, amit } \\
\text { nem fenyeget semmi, amibe } \\
\text { nem vegyül semmi, ami } \\
\text { hirtelen olyan töménnyé } \\
\text { sürüsödött, amilyenné } \\
\text { egyáltalán tud... soha ilyen } \\
\text { töménységet csak úgy, csak } \\
\text { mert itt van, mert én benne } \\
\text { vagyok, a kis piros falban, a } \\
\text { futónövények virágaiban, a } \\
\text { fákban, a füben, a rezgő } \\
\text { levegőben... bennük vagyok, } \\
\text { és nincs semmi más, semmi, } \\
\text { ami nem ők, semmi, ami } \\
\text { nem én vagyok. }\end{array}$ & $\begin{array}{l}\text { nem... „beteljesedés”, } \\
\text { „lelkesültség”, túl } \\
\text { visszataszítóak, ne is } \\
\text { érintkezzenek vele... és } \\
\text { „eksztázis”... ez elött a szó } \\
\text { elött mindaz, ami itt van, } \\
\text { összezsugorodik... „Öröm”, } \\
\text { vagy, talán... ez a kis } \\
\text { szerény szó, egészen } \\
\text { egyszerü, nagyobb veszély } \\
\text { nélkül érintheti... mégsem } \\
\text { képes magába süríteni } \\
\text { mindazt, ami betölt, } \\
\text { túlcsordul bennem, } \\
\text { szétárad, eltünik, beleolvad a } \\
\text { mályvaszín téglákba, a } \\
\text { felfuttatott virágokba, a } \\
\text { pázsitba, a rózsaszín és fehér } \\
\text { szirmokba, az alig észlelhető } \\
\text { hullámremegéstől, } \\
\text { élethullámoktól, röviden } \\
\text { élettől rezgö levegőbe... } \\
\text { melyik másik szó? ... } \\
\text { érintetlen élet, semmi } \\
\text { fenyegetettség, semmi } \\
\text { keveredés, hirtelen olyan } \\
\text { sürítetten mutatkozik meg, } \\
\text { mint soha... soha többé, } \\
\text { semmilyen okból nem lesz } \\
\text { ilyen erős egy érzet, mert } \\
\text { most ez itt van, én benne } \\
\text { vagyok, a kis mályvaszínű } \\
\text { falban, a felfuttatott virágok } \\
\text { sorában, a fákban, a } \\
\text { pázsitban, a remegő } \\
\text { levegőben... bennük vagyok } \\
\text { és semmi több, nincs } \\
\text { semmim, mi az enyém, csak } \\
\text { mi övék. }\end{array}$ \\
\hline
\end{tabular}

A fenti szövegrész alapgondolata, hogy az életben a boldogság nem egyfajta folyamat vagy még rosszabb esetben a megszerzett javak, hanem azoknak a pillanatoknak a sora, amelyekben sikerül mintegy leválnunk önmagunkról és a környezeti hatások, érzetek pozitív sodrásában feloldódni, önmagunkat elveszítve magunkra találni. Ez a gondolat ismert a

\footnotetext{
${ }^{590}$ Sarraute, Nathalie, (1995) p. 66-67.
} 
filozófia- és az irodalomtörténetből egyaránt. A szövegrészben megjelenő másik alapgondolat, amely szintén nem idegen az irodalomtörténettől, hogy az irodalmi müvek egyik legnehezebb feladata olyan, szavakkal nem pontosan megragadható tartalmak kifejezését célul tüzni ki, mint szépség, szerelem, vagy a fenti szövegrészben a pillanatnyi boldogság.

A szerző ezeknek a gondolatoknak, üzeneteknek a kifejezésére szinte pointillista technikával leírást alkalmaz, amelyet kombinál az elbeszéléssel, abba belevonja. Narrációjában ugyanakkor szinte elvész a mesélő én. Továbbá a megfelelő központozás és szintakszis segítségével szóbeli jellegü, lebegő, a felsorolások és az ismétlések hatására ritmikusan monoton szövegegységet alkot.

Az eredetit pontosan követő fordításban a narráció nagyrészt személytelen jellegü: „Miért akarja az ember újra életre hívni”, „Volt ott” „,valami megjelent... valami egyszeri... ami abban a formájában soha nem ismétlődik meg, egy olyan szenvedélyes érzet”, „mindaz, ami itt van, összezsugorodik...” A fenti idézetekben az általános kifejezésmód dominál, nem a személyes, pedig a visszaemlékezés személyessége az E/1-es narráció elsődlegességét predesztinálná. A szerzőnek ez az elbeszélői gesztusa arra utal, hogy a személyesen átélt eseményt példázattá emeli, hogy ezzel általánosságban megragadható gondolatot, üzenetet közvetítsen. Az önéletrajzi jelleget ugyanakkor a szövegegységben elszórtan jelentkező egyes szám első személyü narrációra utaló megfogalmazás tartja fenn: „ami velem történt...” „Ott ültem”, „Épp hallgattam belőle egy részt... nézegettem” „azt érzem, hogy... de mit?”, „,betölt, túlcsordul bennem”, „bennük vagyok és semmi több, nincs semmim, mi az enyém, csak mi övék”. Érdekes ugyanakkor megfigyelni, ahogyan a leírásokkal megszakított elbeszélés egyes szám első személye az „érzetről” való beszéd fordulatát követően már csak az azzal való kapcsolatában jelenik meg, mintegy hidat hozva létre az érzet és a világ között, feloldódva mind az érzetben, mind a világban:

\begin{tabular}{|c|c|}
\hline valóságos eseményekre fókuszáló & $\begin{array}{l}\text { az érzetre fókuszáló E/1-es } \\
\text { énelbeszélés }\end{array}$ \\
\hline $\begin{array}{l}\text { „,ami velem történt...” } \\
\text { „Ott } \underline{\text { ültem” }} \\
\text { „Épp hallgattam belőle egy részt... } \\
\text { nézegettem” }\end{array}$ & $\begin{array}{l}\text { „,azt érzem, hogy... de mit?” } \\
\text { „betölt, túlcsordul bennem”, } \\
\text { „,bennük vagyok és semmi több, } \\
\text { nincs semmim, mi az enyém, csak } \\
\text { mi övék” }\end{array}$ \\
\hline
\end{tabular}


Mivel az üzenet elsődlegesen a szubjektum és a világ kapcsolatának jellegére vonatkozik, a külső környezet megjelenítése leírás formájában nagy hangsúlyt kap a szövegegységben. Az első leírás a szövegben a „nézegettem” szó segítségével szinte észrevétlenül illeszkedik az E/1-es elbeszélésbe: „nézegettem az alacsony, mályvaszín téglafal felfuttatott virágait, a bontakozó fákat, a fehér-rózsaszín szirmú százszorszépekkel tarkított fényeszöld pázsitot, az ég, persze, kék, a levegő pedig mintha lágyan rezegne...”. A szövegnek sajátos ritmust ad, hogy ezt a szövegrészt még kétszer megismétli, egyszer az érzettel kapcsolatban, de ott is leíró jelleggel megjeleníti, ahogyan az érzet túlárad a mesélő énben és feloldódik ezekben a már egyszer leírt valóságelemekben, másodszor pedig az érzetet követve maga a mesélö én mint szubjektum is feloldódik a világban, s erre a feloldódásra ismét az első leírásban felidézett valóságelemeket használja fel.

„ez a kis szerény szó, egészen egyszerü, nagyobb veszély nélkül érintheti... mégsem képes magába sủríteni mindazt, ami betölt, túlcsordul bennem, szétárad, eltủnik, beleolvad a mályvaszín téglákba.....", továbbá: „,mert most ez itt van, én benne vagyok, a kis mályvaszínű falban....”.

A leírás szubjektivizálása ilyenformán észrevétlenül, lágyan ránt minket a szövegvilágba, átélhetővé teszi az én és a világ teljes egységének, az én világban való feloldódásának gondolatát.

A szövegben megjelenő másik üzenetet, a pillanatnyi érzetek verbális kifejezhetetlenségének gondolatát is szépirodalmi eszközökkel osztja meg velünk a szerző. A megszemélyesítés stíluseszközét alkalmazva stilizálja a legtöbb fogalmat, üzenet jelleget, kérdést tartalmazó szövegrészt, amely a szövegegység közepén található:

„valami megjelent... valami egyszeri... ami abban a formájában soha nem ismétlődik meg, egy olyan szenvedélyes érzet, hogy még most is, annyi idő múltán, mikor elhalványulva s részben elmosódva felidéződik, azt érzem, hogy... de mit? milyen szó képes megragadni? nem a mindent elmondó „boldogság” szó, amely elsőnek jelentkezik, nem, ez nem...”

Különös, a kérdések áradatának és a különféle fogalmak bevezetésének köszönhetően már-már gondolatinak, filozófiainak értelmezhető szövegrészt a szerző visszarántja a szépirodalom térfelére úgy, hogy a szöveg későbbi részében megszemélyesíti az érzetet, és az azzal kapcsolatban szóba kerülő elvont fogalmakat. Így mintegy allegorikusan építi be őket egyperces lírai szövegrészébe. Az alábbi idézetekben a megszemélyesítésre, az elvont fogalmak allegorizálását elősegítő életképi narratív elemekre aláhúzással hívom fel a figyelmet. A „beteljesedés”, „lelkesültség” pl. „túl visszataszítóak”, „,ne is érintkezzenek vele...” és „eksztázis”... ez előtt a szó előtt mindaz, ami itt van, összezsugorodik... „Öröm”, 
vagy, talán... ez a kis szerény szó, egészen egyszerü, nagyobb veszély nélkül érintheti...” Meghatóan szép, ahogyan a felhasznált szóképek segítségével átlirizálja, és az ismétlődő próbálkozások segítségével ritmizálja, retorizálja fogalmi szinten is gazdag szövegét a szerző.

A sajátos központozás, azaz a vesszők, a pontok, a kérdőjel és a három pont szolgál a szöveg sajátos szintaktikai-stilisztikai felépítésének kialakítására. Alapvetően hosszú mondatokból áll a Gyerekkor címü regénynek ez a részlete. A tagmondatokat és a szószerkezeteket vesszők választják el, ugyanakkor a mondatok közötti írásjelet, a pontot gyakran atipikus központozás helyettesíti. Előfordul az is, hogy a kérdőjel tagmondatokat választ el és utána közvetlenül kisbetüvel következik a következő tagmondat. A pont, a kérdőjel, a vessző és a három pont egymást váltva különös lebegésben tartja a szövegegészt, ugyanakkor megállapítható, hogy mindegyiknek sajátos stilisztikai szerepe van. Már az első mondat kérdést fogalmaz meg, de a kérdőjelet három pont helyettesíti. A részlet több pontján mégis feltűnnek tagmondatzáró kérdőjelek, hogy felhívják a figyelmet az Én elbeszélő kérdő formában megfogalmazott közbevetéseire („úgy érzem... de mit is ?”). A kérdések szerepe az érzet megnevezésének bizonytalanságára felhívni az olvasók figyelmét. Az bizonyítja még, hogy a mondathatárok elmosódtak, hogy a nagy kezdőbetük szinte teljesen hiányoznak a szövegböl. A bekezdések szintjén még bizonyos külső logikát észlelünk: mindhárom bekezdés nagy kezdőbetűvel indul és ponttal zárul, vagy legalábbis pontértékű három ponttal.

A központozás tehát a szöveg belső logikáját követi és nem külsődleges szabályrendszert. Ez a három pont alkalmazásából is kitünik, amely a fenti részletben, de a Gyerekkor egészében jelentőséggel bír. A pont helyett éppúgy állhat, mint a vessző vagy a kérdőjel helyett. A pontértékü három pontok visszatérö jelensége megváltoztatja a mondatok közötti viszonyokat, de ezeknek nem szintaktikai, hanem stilisztikai jelentősége van, a bizonytalanság, az ambivalencia, a töprengés, a lassabb ritmusra váltás jelentését hordozhatják: „Épp hallgattam belőle egy részt... nézegettem az alacsony, mályvaszín téglafal felfuttatott virágait.” De állhat tagmondatok között is: „valami megjelent... valami egyszeri...”, a három pont ilyenkor vessző helyett áll. Úgy gondolom, hogy a vessző és a pont helyett alkalmazott három pontnak „pneumatikus”591 funkciója van és arra szolgál, hogy lelassítsa a szöveg ritmusát, egy gondolatnyi szünetet sugalljon az olvasónak. A másik szerepe (és értéke) a három pontnak ettől egészen eltérő: célja a szintaktikus viszonyok és

\footnotetext{
${ }^{591}$ Herschberg-Pierrot (1993) p. 266-267. La conception pneumatique de la ponctuation remonte au XVIII ${ }^{\mathrm{e}}$ siècle. La rencontre du besoin de respirer et du besoin esthétique entraîne que l'art d'indiquer dans l'écriture la proportion des pauses par la ponctuation a toujours eu, et a aujourd'hui aussi une valeur stylistique.
} 
szabályrendszer felborításának elkendőzése. Észrevehető például, hogy a tárgyat vonzó igék után vagy megkésve érkezik a bővítmény, vagy végül is teljesen kimarad a mondatból. A három pont arra szolgál, hogy ezek a szintaktikai hiányosságok ne az érthetőséget gátolják, hanem gondolatébresztőek legyenek az olvasó számára. Gyakran a szövegrészben a tárgy vagy az alany általános vagy határozatlan névmási formában jelentkezik: „Miért akarja $\underline{\mathrm{az}}$ ember újra életre hívni mindezt”, „valami megjelent... valami egyszeri...” Erre a bizonytalanságra erősít rá a három pont stílushatása. A közbevetések sokszor egészen messzire sodornak egymástól összetartozó mondatrészeket, ezzel is erősíti a szerző a pontos kifejezés lehetőségének elbizonytalanítását: „,nem tudják megragadni, tartóztatni, ha tovább nem, csak egy-két pillanatra, ami velem történt”. Ugyanez, a kifejezés bizonytalansága jelentkezik a három pont stilisztikájában: „azt érzem, hogy... de mit?” Ugyanakkor az összetartozó tagmondatok szétválasztása megjeleníti a késleltetés stíluseszközét a szintaxis szintjén, további feszültséget keltve ezzel az olvasóban.

Összefoglalóan a fenti szövegegységben szereplö három pont esztétikai értékét olyan fogalmakkal jelölhetjük mint „lassítás”, „késleltetés”, „várakozás”, „gondolatcsend”, A három pont függetlenedik a pont vagy a vessző szintaktikai szerepétől és stilisztikai erőtérrel rendelkezik: jelzi a szüneteket, azaz megállítja az elbeszélés időbeli előrehaladását, és teret enged az olvasó szöveggel kapcsolatos gondoltainak ízlelésére, érlelésére. A fenti szöveg központozásának alapalakzata ugyanakkor az ellentét, hiszen a három ponton kívül használt legfontosabb írásjel a vessző. Miközben az egyik oldalon a három pontok lassítják a szöveget, a vesszők gyorsítják, hozzáadott stilisztikai értékként megjelenítik a felsorolást, ezzel belső feszültséget keltve az olvasóban. A feszültség forrása a mondatszerkesztésnek az a sajátossága, hogy a vesszővel elválasztott tagmondatok halmozása felsorolás jellegénél fogva gyors, egyre gyorsabb lélegzetet kapkodó beszédmódot juttat eszünkbe. A prózastilisztikában „szétdarabolt mondatnak” nevezett jelenség ${ }^{592}$ többször ismétlődik a szövegegészen belül, és az énelbeszélő elbizonytalanodását jelzi, valahányszor pontosan szeretne kifejezni valamit. A rövid tagmondatok halmozása tartogat ugyanakkor egyfajta dinamizmust, kétségtelenül a szóbeli kifejezés ritmusát ${ }^{593}$ idézi és oly jellemző a sarraute-i prózapoétikára.

A szövegegység központozásának és mondatszerkesztésének összefüggései tehát erős irodalmi hatást keltenek, és a szöveg külső logikája helyett (nyelvtani szabályok) annak belső

\footnotetext{
${ }^{592}$ Fromilhague, Catherine (1992). Introduction à l'analyse stylistique, Paris, Bordas, p. 191.

${ }^{593}$ Herschberg-Pierrot (1993) p. 269.
} 
logikáját követik. A kevés pont, a felkiáltójelek ${ }^{594}$ teljes hiánya, a pontosvessző teljes hiánya, a számos három pont, vessző és a kérdőjel sajátos alkalmazása (vagy akár három ponttal való helyettesítése) kapcsán tehát megfigyelhető, hogy a klasszikus prózai szövegépítkezést felváltja egy új, a gondolat és érzés logikáját követő, szóbeliséget idéző retorikus szerkezet. A szereplő klasszikus karaktere is feloldódik ebben a folyamatban. Nem igyekszik megalkotni saját gyermekkori énjének személyiségrajzát, hanem a fenti írástechnikákkal - három pontok, ritmizálás, általánosító szerkezetek, inkább a dadogás poétikáját és a személyiség feloldódását hirdeti.

Gilles Deleuze Abécédaire-ében így jellemezte az E betünél (mint Enfance) Nathalie Sarraute regényét:

\begin{abstract}
„Nathalie Sarraute nagyon nagy író. A Gyerekkor nem egy, a gyerekkoráról írott regény. Kitalál egy gyerekkort. Végül is mi érdekli Nathalie Sarraute-ot a gyermekkorából? Azok a klisék, amelyekböl csodákat old el. Talán ez ugyanaz, mint amit Csehov utolsó szavaival csinált. Kislányként hallotta, hogy valaki azt mondja: „Hogy vagy?” Mi ez a „Hogy vagy?” - kioldja belőle nyelvi univerzumát, önmagára tükrözteti a nyelvet." 595
\end{abstract}

Sarraute önéletrajzi regényében az arctalanítás poétikájának eszköztára a dialógusforma, az igeidők és a központozás jellegzetes használatából tevődik össze. Ezek segítségével bontja le a szereplő klasszikus értelmezhetőségét a müben, hogy ne emlékeket idézzen gyerekkorából, hanem képes legyen megidézni a régvolt pillanatokat, személyeket és régvolt önmagát.

\title{
VI.5. Molekuláris szereplök - Tu ne t'aimes pas
}

„Ön nem szereti önmagát.” - ebből a banális mondatból indul el és bontakozik ki a szerző Tu ne t'aimes pas [Nem szereted magad] (1989) címü regénye. A párbeszédes szerkezetủ mü - amelyben a már-már sejtjeire, molekuláira bomlott személyiség éndarabkái társalognak egymással - lényegi gondolata, hogy az ember belső világa túl összetett, túl meghatározhatatlan ahhoz, hogy egy-egy ilyen rögzült képet, summás mondatot társítani lehessen hozzá. Szubjektivitásunk puzzle-je ennél sokkal mozgékonyabb, szubjektumtöredékeink összeállnak, szétválnak, sokasodnak, elkülönülnek, kiválnak, újraformálódnak, és ennek a változó énhullámzásnak a ritmusa adja az én valóságát, nem az igaznak tűnő véleményt kifejező mondatok. A szövegvilág mi-je a darabjaiból felépülő

\footnotetext{
${ }^{594}$ Herschberg-Pierrot (1993) p. 17. Modalisation: la valeur propositionnelle d'un énoncé, sa valeur d'acte de langage, définie par sa force illocutoire.

${ }^{595}$ Deleuze, Gilles (1988). "E comme Enfance", L’Abécédaire, téléfilm réalisé par Michel Pamart. in Tiszatáj. 2016. 09.
} 
szubjektum $^{596}$. A szerepeltetett ő nagy elánnal szereti magát, gondolatai „magasra

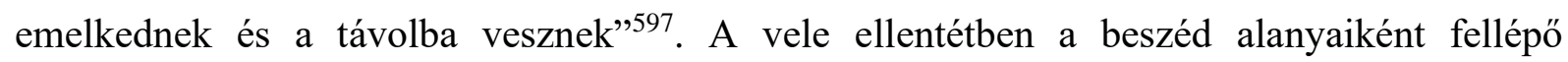
mozgékony mi-molekulák, akik nem szeretik magukat, valahol mintha, a már korábbi elemzésekben említett haptikus látásfogalomnak megfelelően, különböző érzékterületek keveredéséből, szinesztéziák segítségével építenék fel magukat újra és újra, bontakoznának: „Áthatóan nézi az asztalon pihentetett kezét”598. „Kezén pihenő tekintetéből gyengédség folydogál”599. A következő kifejezés pedig mintha a tropizmusokat visszhangoznák: „,selymes kőkockák”, „,benapozott terek”, „meleg érintésű vakolat”600.

A stílushatásokból, alapvetően a szétszabdalt szubjektum részeinek megszólalásaiból formálódó szöveghez nem társítható egyértelmü értelmezés, azonban a kérdésfeltevések mégis megközelítőleg a következők: van-e önszeretet, mi a szeretet-önszeretet viszonya nárcisztikus világunkban, hogyan épül fel az önmagát szerető személyiség, hogyan épül fel az önszeretetre nem hajló személyiség ${ }^{601}$ ? Foucault szubjektumelméletére ${ }^{602}$ asszociálhatunk a Sarraute-müben előforduló énfogalom kapcsán. Ez határozottan ellentétben áll a cogito egységességét, strukturális szervezettségét fenntartó filozófiákkal, például Sartre társadalmilag felépülő, vagy Freud mélylélektani struktúrákból összeálló énfogalmával. „Azz én lerombolódott... (...) nem az emberrel helyettesítjük Istent, hanem egy névtelen gondolkodásmóddal, tárgy nélküli megismeréssel, azonosság nélküli elmélettel." ${ }^{603}$ Foucault egyik fö fogalma a genealógia, melynek lényege, hogy az események egyszeriségét előtérbe helyezve háttérbe szorítjuk a finalitást. A szubjektumot pedig úgy tekinti, mint különféle névtelen struktúrák puszta összjátékát. „Egy anonim és kényszerítő erejű gondolkodási rendszerben gondolkodunk"604.

\begin{tabular}{|l|l|}
\hline "Vous ne vous aimez pas." Mais comment & - Ön nem szereti önmagát. Hogy is van ez? \\
ça ? Comment est-ce possible ? Vous ne & Hogy lehet ez? Hogy van az, hogy ön nem \\
vous aimez pas ? Qui n'aime pas qui ? & szereti önmagát? Ki nem szeret kit? \\
- Toi, bien sûr... c'est un vous de politesse, & $\begin{array}{l}\text { - Te, természetesen... az önözés csak } \\
\text { udvariassági formula, az „önnel” valójában }\end{array}$ \\
\hline
\end{tabular}

${ }^{596}$ Nathalie, Sarraute (1992). À voix nue, cinquième entretien avec Danièle Sallenave, France Culture, 26 mars 1992.

${ }^{597}$ Courson (2008). „très haut, vont se perdre au loin”

${ }^{598}$ Sarraute, Nathalie (1989). Tu ne t'aimes pas, Gallimard, p. 20.

${ }^{599}$ Uo. p. 21. „Son regard posé sur elle d'où ruisselle l'attendrissement...”

${ }^{600}$ Courson (2008). "dalles soyeux, des places ensoleillées, pans de mur au ferme et chaud contact..."

${ }^{601}$ Brulotte, Gaëtan (1990). "Du côté de ceux qui ne s'aiment pas, Nathalie Sarraute, Tu ne t'aimes pas", Paris, Gallimard, 1989. in Liberté Volume 32, numéro 2 (188), avril 1990. Elérhetö: https://id.erudit.org/iderudit/31893ac, Letöltés ideje: 2020. január 18.

${ }^{602}$ Foucault, Michel, Örület és társadalom, A dolgok rendje, A tudás archeológiája

${ }^{603}$ Fürst, Maria (1993). Bevezetés a filozófiába, Ikon Kiadó p. 139-140. idézi Foucault

${ }^{604}$ Uo. idézi Foucault 
un vous qui ne s'adressait qu'à toi.

- À moi ? Moi seul ? Pas à vous tous qui êtes moi... et nous sommes un si grand nombre... "une personnalité complexe"... comme toutes les autres... Alors qui doit aimer qui dans tout ça?

- Mais ils te l'ont dit : Tu ne t'aimes pas. Toi... Toi qui t'es montré à eux, toi qui t'es proposé, tu as voulu être de service... tu t'es avancé vers eux... comme si tu n'étais pas seulement une de nos incarnations possibles, une de nos virtualités... tu t'es séparé de nous, tu t'es mis en avant comme notre unique représentant... tu as dit "je"... ${ }^{605}$ hozzád fordulok.

- Hozzám? Csak hozzám? Nem hozzátok, akik mind én vagytok... és annyian vagyunk..., „összetett személyiség”... mint bárki más... Akkor kinek is kellene szeretni kit?

- De világosan megmondták neked: nem szereted magad. Te... megmutattad magad nekik, felajánlkoztál, felajánlottad szolgálataidat... feléjük léptél... mintha nem csak egy lennél megtestesüléseink közül, virtualitásaink közül... kiváltál közülünk, elötérbe léptél, mint aki képviselhet minket, azt mondtad: „én”...

Guattari szavaival élve minden átalakulás „molekuláris leendések”606 sorozatán át zajlik. A bennünk formálódó leendések, ahogyan a fenti Sarraute-szövegben is szerepel, külső-belső virtualitásokból, „szingularitás-ködökből”607 építkeznek. Sarraute tropizmusfogalma kapcsolódhat Deleuze és Guattari „növény-leendés”-terminusához, amennyiben azt sugallja, hogy molekuláris szinten, a „növényi zónáinkból” felszivároghat létünkbe valamiféle, már-már szabad szemmel nem látható, sejtek szintjén lezajló mozgássor ${ }^{608}$. A Deleuze-Guattari-filozófiában a molekuláris a molárissal alkot fogalompárt. A molekuláris szint a minoritások mozgalmasságát jelenti, továbbá mindig virtuális, és lényege, hogy a valóság belőle áll össze. „Minden alany és tárgy molekularizálódik”609 - ez a gondolat párhuzamba állítható a sarraute-i szövegvilág lebomló szubjektumával, amely virtualitásainak hullámzásában érzékelhető és nem a filozófiai vagy pszichológiai hagyományból megismert énként. A szuverén szubjektumot „ezer kis lárvaszubjektummal” helyettesítik, „ezer kis felbomlott énnel, ezernyi passzivitással és zürzavarral”610.

A nyelv minorizálása a deleuze-i gondolatmenetben összefügg a hatalmi struktúráktól függetlenedő nyelvi apparátussal és az ismétlő, mellérendelő, dadogó, hezitáló stílusformákkal:

\footnotetext{
${ }^{605}$ Sarraute (1989). p. 9.

${ }^{606}$ Guattari, Félix (1977). La révolution moléculaire p. 19., 171. devenir-moléculaire

${ }^{607}$ Uo. ,brouillard de singularités”

${ }^{608}$ Deleuze-Guattari (1980). Mille plateaux, p. 337.

${ }^{609}$ Villani-Sasso (2003). p. 354. „molécularisation de tous les sujets et de tous les objets”

${ }^{610}$ Fürst (1993). p. 140. idézi Deleuze
} 
„redundancia mint létezésmód és a jelszavak továbbítása, alatta az információ-arc mint az a minimum, ami szükséges a jelszavak megértéséhez ${ }^{611}$, még lejjebb pedig az a valami, ami éppúgy lehet kiáltás, mint csend vagy dadogás, szökésvonal ki a nyelvböl, idegenként beszélni az anyanyelvet, minorizálni a nyelvet..." 612

A nyelvnek ez a minorizált alakulásformája a molekuláris zónabeli köd, az ott kibontakozó szingularitássorok, amelyből a Tu ne t'aimes pas tropizmusai is kifejlődnek. A különböző, molekuláris szinten ködlő szubjektummorzsák, szingularitások beszélgetése elvont prózaszöveget eredményez. Ugyanakkor jól felismerhető benne a Gyerekkorból már megismert dialógusforma, amelynek segítségével akkor is megkérdőjelezte az individuum egységének lehetőségét, de ott csupán két jól elkülöníthető identitás-tükörképre bontotta. Ehhez képest azonban a Tu ne t'aimes pas esetében a dialógus a szubjektumpillanatok megszólalásaiból áll, a korábbi könyvek dadogó, mondandóját újraformáló stílusában. Ezek a töredékek csak látszólagos párbeszédek. Valójában, mivel nem személyek között, hanem mintegy molekuláris szinten zajlanak, ezért topizmusokból, önellentmondásos igazságpillanatokból, pattogó ritmusú gondolatsorokbók, élőszóbeli idézetekből, mini beszédhelyzetekből állnak össze ${ }^{613}$.

Késői regényében Sarraute az arctalanítás poétikáját úgy valósítja meg, hogy a Gyerekkorban már alkalmazott dialógusformát újrateremti, ezzel megidézi a sokasodó szubjektumköteg változáspillanatait. Ez a műve azért is érdekes, mert már-már szembeállítja egymással az arcadást, a magát szerető szubjektum nézőpontját és az arctalanítást, a magát nem szerető, sokféle alakot öltő deszubjektivizált ént.

\section{Végkövetkeztetés, összefoglalás}

Disszertációm fő feladata volt, hogy megvizsgáljam az Új Regény, és azon belül a magyar recepcióban méltatlanul elhanyagolt írónő, Nathalie Sarraute életművében a szereplő alakulástörténetét és jellegzetességeit. A szereplővé írás sarraute-i látásmódjához való eljutás folyamataként fontosnak tartottam végigtekinteni a szereplőfogalom XX. századi fő értelmezési keretein. Rövid irodalomtudomány-történeti összefoglalómból az derült ki, hogy az arisztotelészi mimézistől és normativitástól már az elkötelezett irodalom művelőin kívül számos XX. századi prózaíró tudatosan igyekszik eltávolodni. A hősök elpusztítása

\footnotetext{
611 ez a moláris szint

${ }^{612}$ Deleuze-Parnet (2016). p. 24.

613 Brulotte (1990.)
} 
megkezdődik, leszámolnak a karakterrel, de számukra a valóság és a regényvilág viszonya továbbra is definiálandó marad. A formalisták elfordultak a hősfogalomtól, hogy jelként értelmezzék a szereplőt. François Mauriac kulcsgondolata a 30-as években, hogy megegyezés kérdése minden: az olvasó tisztában van azzal, hogy a regényekben felbukkanó karakterek nem valóságosak, és ez a tudat elég ahhoz, hogy jól kezelje a valóság és a fikció sajátos viszonyát. A továbbiakban a nyelvészeti fordulat hozott új szereplőértelmezéseket. Ha a nyelv a legfontosabb az irodalmi mü konstrukciójában, akkor a valóságábrázolás természetszerüen lesz kevésbé hangsúlyos. Robbe-Grillet már az individuum sajátos léthelyzetével magyarázza az újfajta szereplőtípusok megjelenését. „Még jelentett valamit, hogy arcunk volt egy olyan univerzumban, ahol a személyiség egyszerre jelentett megtalálandó eszközt és célt az emberek számára." ${ }^{614} \mathrm{Ha}$ igaz az, hogy régen még az arc jelentett valamit, akkor az is igaz, hogy megkezdődött az arctalanitás folyamata. Az Új Regény hőse lassan elveszti gyökereit, elődeit, társadalmi státuszát, életterét, javait, arcát, jellemét, sőt, a nevét is.

Ehhez az újfajta szereplöértelmezéshez kapcsolódik Nathalie Sarraute, aki $A$ gyanakvás kora címü esszéjében, az 1950-es években az érvelés logikájának középpontjába a főhős iránti bizalmatlanságot helyezi. Az olvasó nem hisz a szereplő jellemábrázolásának valószerüségében, az író pedig abban, hogy szereplői még életre kelhetnek vagy hogy az olvasó képes lesz egyediségüket maradéktalanul értékelni, értelmezni. Sarraute-nál a szereplő dekonstrukciója elsődleges a klasszikus narrativitás többi tényezőjének, a cselekménynek és az időfaktornak a lebontásához képest, ez utóbbiak annak folyományai. Sarraute arra vágyik, hogy helyreállítsa ezt az elvesztett bizalmat, de nem az új illúziók keltésének módszerével, hanem azzal, hogy a szereplök megalkotásakor az olvasó fizikai érzeteire (látás, hallás) támaszkodva érzelmi-gondolati-fizikális rezgéshullámot hozzon létre az olvasó és az író között. Ez lesz a tropizmus, és ezeknek a szóval ki nem fejezhető érzetkötegeknek lesznek a Sarraute-szereplők csupán foglalatai.

A Sarraute-esszékkel nagyjából egyidőben, illetve a 60-as, 70-es években a strukturalista elképzelések (pl. Greimas, Hamon) mentén különféle narratív modellek megszületésének lehetünk tanúi. Ezek tudományos igényességgel fektetik le a szereplök egymáshoz, illetve a befogadónak a szöveghez, a befogadónak az alkotóhoz való viszonyát. A formalizmus nyomdokain járva értékes gondolatrendszert hoztak létre: modellszerü szereplőelméleteik olyan terminológiát, szakszókincset teremtettek, amelyek nélkülözhetetlenek jelenlegi interpretatív gyakorlatunkban. Továbbá a világ térfeléröl 
áthelyezték az értelmezési tartományt a szövegre vagy a nyelvre, a kontextusról a kotextusra. Jouve elmélete a szereplőértelmezésben a befogadói attitüdre fókuszál. Hatás-szereplö terminusa arra utal, és ez már kimutat a sarraute-i gondolatra, hogy nem az a lényeg, mit szeretne ábrázolni az író a szereplő megalkotásával vagy mit ábrázol, hanem az a lényeg, hogy milyen kapcsolatba kerül az olvasó és a szereplő a regényvilággal való találkozása során.

Megindul egyfajta arctalanítási folyamat, melynek lényege a deszubjektiváció, a szövegimmanens individuumok elötérbe helyezése a célzott megalkothatóság ellenében, illetve a deszignifikáció, amely az olvasó befogadói attitüdjének kiélesedését, csiszoltságát igényli a szándékolt szövegjelentéssel szemben. Az arctalanítás poétikája a fenti gondolatmenet megvalósítása a szövegek nyelvi-stilisztikai szintjén, és ebben Nathalie Sarraute mind esszéiben, mind szépirodalmi szövegeiben rendkívül következetes és hatékony alkotó. Nála a szereplő stilisztikai megalkotottsága tudatos távolságot tart az esztétikai célú kommunikáció illusztrálásával. A szövegben felsejlö alak, figura, arctalanított dinamika a tropizmus maga. Az arc realista, ilyen értelemben Nathalie Sarraute szereplöi modellje az arctalanítás, az arctól való eltávolítás folyamatához kapcsolható.

Sarraute stílusinvenciójának lényege, hogy a tropizmus-foglalat, tehát a tropizmust hordozó szereplő-alak, a szómögöttes beszédfolyamnak közvetlenül a mentális struktúrákból feltörő, kiáramló, ilyen értelemben a kognitivitásunk szivacsosságát formátlanul tükröző mélyrétegü valóságából nő ki. Mindez az irodalmi megvalósítás szintjén a stílusban, a nyelvi eszközök sajátos használatában sejlik fel. Magyarul bebizonyítható, hogy az újfajta szereplö nem jellemében vagy karakterében, hanem a szöveg nyelvi felépítettségében és stílushatásokban létezik. Ám ez a stílushasználat nem a választásalapú stilisztika egy sajátos változata, hanem magában a stílusban, a maga hezitáló, dadogó, újrakezdő, újramondó, metonimizáló, szinesztézikusan fel-felbuggyanó araszolásában van. A tropizmus tehát ilyen értelemben a szereplő, a stílus, a müfaj egyaránt az irodalmi szöveg tekintetében. „Valamennyi könyvem témája a születőben lévő, megnevezhetetlen, a tudati szintre még el nem jutott, de a tudati szint fölé jutva frázissá váló mozgás, mely folyamatos átalakulásban, állandó leendésben van."

S mivel a leendés áramlás, folyamat, nem lehet jelölők és jelöltek csapdájába csalni „a leendések a legészrevétlenebbek: olyan cselekvések, amelyeket csak egy élet tud magába

\footnotetext{
${ }^{615}$ Sarraute, Nathalie (1996). "La littérature, aujourd'hui" in Euvres complètes p. 1662.
} 
foglalni, csak egy stílus tud kifejezni." ${ }^{, 616}$ Akárcsak Sarraute számára, Deleuze számára is a stílus rizomatikus, nem az egyén vertikális hierarchiája tükröződik benne, hanem a rizóma horizontalitása, variánsokból építkező elrendeződése. A tropizmus-foglalat a stílusból születik, szöveg-leendésben van és abból nyer életet, múlt és jövő nélkül, individuációk sorából mutatva meg magát. ${ }^{617}$ Deleuze az arctalanítás szükségességét a szubjektumtól és a jelentéstől való függetlenedésben látja ${ }^{618}$.

Nathalie Sarraute tropizmusai a szereplőformálás új, fenti stílusinvencióját valósítják meg Deleuze szavával élve az alkotás haptikus funkciójának megfelelően. A müvészet harmadik szeme által ragadja meg az elevenséget, „mintha vizuálisan meghaladtuk volna a taktilis és az optikai kettőségét a (...) haptikus funkciónak az irányában.”619 A tapintással láttatott tropizmus mindaz a Sarraute-univerzumban, ami a hagyományos prózai művekben a cselekményvezetés, a szereplő, a kronologikus időkezelés. A tropizmus nem egy adott szereplő története egy helyszínen az idő egy pontján, hanem a szómögöttesből szerveződő jelenidejű képáramlat. A Sarraute-szövegekhez köthető tropizmikus alkotási-befogadási folyamat gyógyír a valóság ábrázolhatóságával és a nyelvi közlések értelmezhetőségével kapcsolatos gyanakvásra. Nyelvileg a tropizmus ritmusát a következők adják: ismétlődések, fragmentáltság, egyidejűség, analógiák, az időbeli linearitás, az oksági viszonyok ellehetetlenítése, tér,- és időviszonyok egyértelműségének feloldása.

A tropizmussal átitatott szereplő-alak szövegekben való vizsgálatából kiderült, hogy a Tropizmusok világában jellegzetes metonimikus utalásrendszer segítségével mutat rá a szöveg az esetleges beszédhelyzetekre vagy történésekre. A tropizmus szereplöinek kapcsolatrendszere leírható úgy, hogy az alakok tropizmus-hordozókká válnak, akiket nem egyszer a tropizmikus szintjükön megélt csöndtörténéseikben kíván leleplezni a tropizmus ellenlábasa. Ez a leleplezés abban áll, hogy fix jelentéseket, konceptualizált érzelmeket, előregyártott kliséket kíván a tropizmus-szereplőkhöz,- és -helyzetekhez társítani. A tropizmus ugyanakkor nem csak szereplőalkotási folyamat, hanem azon túlmenően müfaj is, amely a kettőközöttiségben, fikció és dikció határán egyensúlyozó leendésben bontakozik ki. Végül a tropizmus idővonatkozásait megvizsgálva rámutattunk, hogy az írónő célja a tropizmus-hordozót ebben a fikció-dikció közötti szövegvilágban az örök jelenbe úsztatni. Ennek stilisztikai megvalósulása a Tropizmusokban az imparfait alakok szinte kérödzö

\footnotetext{
${ }^{616}$ Uo.

${ }^{617}$ Deleuze, Gilles, Guattari, Félix (1980).

${ }^{618}$ U.o. l'asignifiant, l'asubjectif

${ }^{619}$ Deleuze (2014). pán. 85.
} 
használata. A Tropizmusok hátterében lévő gondolatrendszer és az azokat felépítő nyelvi megoldások tehát elörevetítik a teljes életmüre vonatkozóan a jellegzetes sarraute-i szereplőképzést és nyelvhasználatot.

A későbbiekben, az egyes müvek egyenkénti vizsgálatánál azt bizonyítottuk, hogy a tropizmusban már megfigyelt arctalanítás poétikája az alapja a további müvek szereplőformálásának is. Részletesen csupán öt Sarraute-mű elemzésére adott keretet a disszertáció: a Portrait d'un inconnu, a Planetárium, a Les fruits d'or, a Gyerekkor és a Tu ne t'aimes pas. Korai regényeiben, az elszigetelt hősök világában látszólag még mintha arcot adna számukra, mintha belegabalyodna a jellem, a név, a viselkedésmód, a kapcsolatrendszer hálójába. A szövegek vizsgálata azt bizonyította, hogy az életmü érése során az arcadás látszata átadta helyét az arctalanítás poétikájának, ugyanakkor a szómögöttes tartalmak feltárása és a sarraute-i tropizmikus írástechnika kiforrott jelenléte valamennyi szépirodalmi münek sajátja maradt.

A Portrait d'un inconnu címü regényében az egyes szám első személyű elbeszélő egy festménnyel kialakított bensőséges kapcsolata révén a különleges, haptikus, tapintó látás képességére tesz szert és rájön, hogy az általa addig megfigyelt két alak (apa és lánya) arctalanítása révén juthat el értelmezhetetlenségük elfogadásáig. A következő vizsgált regényben, a Planetáriumban a tropizmus középpontjában látszólag arcot kapott, névvel, társadalmi helyzettel ellátott szereplők állnak, és az ő tárgyakhoz, életeseményekhez és személyekhez (fotel, lakás, ajtó, irodalom, karrier, nagynéni, művészvilágbeli „föguru”) füződő viszonyrendszerük egyúttal mintha értékítélet nélküli prioritásokhoz való kapcsolódást is jelentene (karrierizmus, zsugoriság, siker, féltékenység, álompár). Az arctalanítás alanyai és tárgyai itt maguk a szereplök. Ennek szövegszerü, poétikai vetülete a szó és a szómögöttes közötti folyamatos átjárás, konklúziója pedig az, hogy szembe kell néznünk önmagunk, szeretteink, élethelyzeteink, vágyaink kiismerhetetlenségével. A Les fruits d'orban a személyes névmási szereplők kapcsolatrendszere rendkívül komplex, hiszen a $t u$-n kívül valamennyi mozgásba lendül, illetve fel is oldódik az on általános alany használatában. Az arctalanítás poétikája tehát az erőteljes kotextuális (belterjes szövegvilágú) stilisztikai eljárások segítségével valósul meg. A Gyerekkor címü önéletrajzban az énelbeszélő megkettőzésével dekonstruálja a szerző az olvasó által elvárt arcot. Az öntükröző alak dialógusának szerepe, hogy jelenidejüvé tágítja a szerző az emlékezés folyamatát. Az arctalanítás poétikájának alkalmazása tehát itt azt a célt szolgálja, hogy régvolt pillanatokat, személyeket és önmagát idézze meg az öntükröző énelbeszélő. Végül a Tu ne t'aimes pas 
címủ molekuláris gondolatregényben a szeretet-önszeretet problematikáját járja körül a szerző a szereplő szubjektumot sejtjeire dekonstruáló dialógusforma segítségével. Az arctalanítás poétikája itt megidézi a sokaságként vibráló szubjektumköteg változáspillanatait. Szembeállítja egymással az arcadást, a magát szerető szubjektum nézőpontját és az arctalanítást, a magát nem szerető, sokféle alakot öltő deszubjektivizált ént.

Összefoglalva a tropizmusok szereplőalkotásának módszere Nathalie Sarraute teljes életművében az arctalanítás poétikája segítségével valósul meg a szubjektum - akár elbeszélő, akár szereplö - dekonstrukciója révén. Ennek alapvető stíluseszközei az örök jelen biztosítása az igeidők tudatos használatával, a névmási szereplők, a dialógusforma, az egymás mellé helyezések, metonímiák inkább, mint metaforák, a dadogó mód, azaz az újrakezdések, újraformálások, újramondások ritmikája, a beszéd megidézése, a szöveg parole jellegének előtérbe helyezése, a szómögöttes tartalmak szinesztézikus módon való taktilis láttatása. Nathalie Sarraute müveiben a tropizmusokban megfigyelt írói eljárások lényegében a teljes életművön végigvonulnak tehát úgy, hogy megtörténik a klasszikus elbeszélöi módszerek, a mesélés, az időkeret és a jellemformálás újragondolása. Ezekhez a kulcs a szubjektum, azaz az elbeszélő és a szereplő arctalanítása.

A későbbiekben is szeretném folytatni kutatói munkámat, hiszen Nathalie Sarraute életműve és a kortárs francia irodalom még számos engem érdeklő kérdést vet fel:

- A haptikus látás stilisztikai eljárásainak változatai Nathalie Sarraute több müvében

- Nathalie Sarraute írói módszereinek továbbélése, újragondolása kortárs alkotók életművében

- Tipikus sarraute-i motívumok felbukkanása az írónő prózai müveiben (pl. ajtó)

- Mủvek, müvészek és müvészet a Sarraute-prózaszövegekben

- Nathalie Sarraute más müveinek elemző vizsgálata, főleg az Usage de la parole

- Fordítástechnikai, összehasonlító stilisztikai vizsgálatok a Sarraute-szövegek tekintetében

- Kognitív pszichológiai vizsgálatok és belső beszéd - a gondolattól a megszólalásig, és ennek poétikai-stilisztikai vetületei a Sarraute-szövegekben 


\section{Bibliográfia}

Abirached, Robert (1994). „La Crise du personnage dans le théâtre moderne”, Collection Tel $\left(\mathrm{n}^{\circ} 245\right)$, Gallimard

Adert, Laurent (1996). Les mots des autres. Flaubert, Sarraute, Pinget, Presses du Septentrion,

Villeneuve d'Ascap

Amossy, Ruth, Herschberg-Pierrot, Anne (1997), Stéréotypes et clichés, Paris, Nathan

Angremy, Annie (1995). Nathalie Sarraute. Portrait d'un écrivain, Bibliotheque nationale de France

Angremy, Annie (1996). Sommaire Nathalie Sarraute, ADPF, Paris

Angyalosi Gergely (1986). „Új-e még az Új Regény?” in (1996). A költő hét bordája, Debrecen

Arisztotelész (1992). Poétika, Budapest, Kossuth

Avalle, Arco, Silvio (szerk) (1973). Essais de la théorie du texte. La sémiologie de la narrativité chez Saussure, Paris, Galilée

Barthes, Roland (1954). „Littérature objective” Critique 1954. Elérhető: http://aelib.org.ua/texts/barthes_essais_critiques_fr.htm\#07 Letöltés ideje: 2020. 01. 06.

Barthes, Roland (1960). „Écrivains et écrivants”, Arguments Elérhető: http://aelib.org.ua/texts/barthes_essais_critiques_fr.htm\#07 Letöltés ideje: 2020. 01. 06.

Barthes, Roland (1977). „Introduction à l'analyse structurale des récits” in R. Barthes és tsai, Poétique du récit, Paris, Seuil

Barthes, Roland (1996). „A szerző halála” in A szöveg öröme, Osiris p. 50.

Beauvoir, Simone (1963). La force des choses, Collection Blanche, Gallimard

Bénard, Johanne (1980). „Silence, tropisme et stéréotype chez Nathalie Sarraute” Annuaire Théâtral Elérhető: https://id.erudit.org/iderudit/041523ar, Letöltés ideje : 2020. 01. 15.

Benveniste, Émile (1969). „Sémiologie de la langue” in Semiotica, Mouton, La Haye

Besser, Gretchen Rous (1976), „Colloque avec Nathalie Sarraute” The French Review 22 avril 1976.

Benmussa, Simone (1987), Nathalie Sarraute, Lyon, La Manufacture

Benmussa, Simone (1999). Entretiens avec Nathalie Sarraute. La Renaissance du livre 
Elérhető: http://auteurs.contemporaininfo/doku.php/auteurs/nathalie_sarraute, Letöltés ideje: 2020. 01. 05.

Blanchot, Maurice, (1959). Le livre à venir, Paris, Gallimard,

Bókay Antal (1997). Irodalomtudomány a modern és a posztmodern korban, Budapest, Osiris Bouchard, Mawy (dir.), Portrait de l'homme de lettres en héros, Elérhetö:

file://C:/Users/lomba/Downloads/440-Texte\%20de\%20l'article-604-1-1020120801.pdf Letöltés ideje: 2019. 07. 15.

Boué, Rachel (1997). „Un regard tactile” in Nathalie Sarraute. La Sensation en quête de parole, Paris, L'Harmattan,

Bruel, Pierre (1985). „Dieppe ... on parlait de Dieppe’: Essai de lecture comparatiste d'une page de Nathalie Sarraute", Neohelicon: Acta Comparationis Litterarum Universarum, vol. $12, \quad \mathrm{n}^{\circ} \quad 1 \quad$ (1985), $\quad$ p. 17-25. Elérhető https://link.springer.com/article/10.1007/BF02092933, Letöltés ideje : 2020. január 18. Brulotte, Gaëtan (1990). „Du côté de ceux qui ne s’aiment pas, Nathalie Sarraute, Tu ne t'aimes pas”, Paris, Gallimard, 1989. in Liberté Volume 32, numéro 2 (188), avril 1990. Elérhető: https://id.erudit.org/iderudit/31893ac, Letöltés ideje: 2020. január 18.

Butor, Michel (1992). Essais sur le roman, Gallimard,

Butor Michel (1997). Módosulás; ford. Szathmári Éva; Noran, Bp.

Chatelet François (1965). „Peut-il y avoir une sociologie du roman ?” in Annales Année 1965 20-3 p. 490-502. Elérhető: https://www.persee.fr/doc/ahess_03952649_1965_num_20_3_421291 Letöltés ideje: 2019.07.17.

Chebel d'Appollonia, Ariana (1991). Histoire politique de intellecuels en France. (1944-54). Édition Complexe p. $247 . \quad$ Elérhető: https://books.google.fr/books?id=voHuAAAAIAAJ\&hl=fr\&source=gbs_book_other_ versions Letöltés ideje: 2019. 11. 16.

Clayton Alain (1989). Nathalie Sarraute ou le tremblement de l'écriture, Paris, Minard.

Cohn, Dorrit (1981). La transparence intérieure. Modes de représentation de la vie psychique Compagnon, Antoine (1998). Le démon de la théorie, Paris, Seuil

Cormier, Christine (2000). „Topos, tropismes et toponymes dans Portrait d'un inconnu de Nathalie Sarraute". Études françaises, 36 (1), 109-125. Elérhetö: https://doi.org/10.7202/036173ar Letöltés ideje: 2020. január 3.

Courson, Nathalie (2008). „Nathalie Sarraute, écrivain du toucher”, Poétique, 2008/4 n 156, 
pages 473-482., Elérhető: https://www.cairn.info/revue-poetique-2008-4-page473.htm, Letöltés ideje: 2020. 01. 18.

Cranaki, Mimica, Belaval, Yvon (1965). Nathalie Sarraute, Gallimard

Deleuze, Gilles, „Vingt-troisième série de l'Aiôn”, in Logique du sens, Paris, Édition de Minuit

Deleuze, Gilles (1964). Proust et les signes, Paris, Presses Universitaire de France

Deleuze, Gilles, Guattari, Félix (1980). Mille plateaux, Paris, Éditions de Minuit

Deleuze, Gilles, Guattari, Félix (1980). „Visagéité, année zéro” in Mille plateaux;

Capitalisme et Schizophrénie 2 5. fejezet, Les Editions de Minuit. p. 205-234 Elérhető: http://www.philophil.com/philosophie/ représentation/Analyse/deleuze-visage.htm Letöltés ideje: 2020. 01. 14.

Deleuze, Gilles (1988). „E comme Enfance”, L’Abécédaire, téléfilm réalisé par Michel Pamart. in Tiszatáj. 2016. 09.

Deleuze, Gilles - Guattari, Félix (1991). Qu'est-ce que la philosophie? Paris, Éd. de Minuit, Deleuze, Gilles (1993). „La littérature et la vie”, „Bégaya-t-il...” in Critique et Clinique, Les Éditions de Minuit, Paris

Deleuze, Gilles (2014). Francis Bacon. Az érzet logikája, ford. Seregi Tamás, Budapest, Atlantisz Könyvkiadó Elérhető: https://docplayer.hu/2636936-Gilles-deleuze-francisbacon-az-erzet-logikaja.html Letöltés ideje: 2019. 07. 20.

Deleuze, Gilles, Parnet, Claire (2016). Párbeszédek. ford. Karácsonyi Judit, Lipták-Pikó Judit, Gyimesi Timea, L’Harmattan

Dessons, Gérard (2000) Introduction á l'analyse des poèmes, Paris, Nathan

Derrida, Jacques, (1986) Parages, Paris, Galilée

Ducout, Françoise (1984). „Le nouveau roman : vingt-cinq ans après” L'Arc 95 (1984).

Duplay, Mathieu (2003). „Littérature mineur” in. Sasso, Robert, Villani, Arnaud (2003).

Ehwenzweig Anton (1974). L'ordre caché de l'art, essai sur la psychologie de l'imagination artistique, Gallimard

Esterházy Péter: A szavak csodálatos életéből. Elérhető: https://mindentudas.hu Letöltés ideje: 2019. 08. 15.

Fontanille (1999). Sémiotique et littérature (1999), Nathan

Fontaine, David. (1993), La poétique, Paris, Nathan

Fontanier (1968). Les Figures du discours, rééd., Paris, Flammarion, 
Fürst, Maria (1993). Bevezetés a filozófiába, Ikon Kiadó

Genette, Gérard (1972). Figures III., Paris, Seuil,

Genette, Gérard (1979). Introduction à l'architexte, Paris, Seuil

Genette, Gérard (1983). Nouveau discours du récit, Paris, Seuil

Genette, Gérard - Todorov, Tzvetan (1986). Théorie des genres, Paris, Seuil,

Genette, Gérard, Fiction et diction, Paris, Seuil, 1991.

Genette, Gérard (2003) „Fiction ou diction”, Poétique, avril 2003, n p. 131-139.

Goldmann, Lucien (1964). Pour une sociologie du roman, Collection Bibliothèque des Idées, Gallimard

Gosselin-Noat, Monique (2002). „Nathalie Sarraute et la recherche de la vérité” in Critique janvier-février 2002. 656-657.

Geest, Dirk (2003). La sémiotique narrative de A.J. Greimas Elérhető:

http://www.imageandnarrative.be/inarchive/uncanny/dirkdegeest.htm (Letöltés ideje: 2019. 07. 08.)

Greimas, Algirdas Julien (1966). Sémantique structurale. Paris: Larousse.

Greimas - Courtès (1979). Sémiotique. Dictionnaire raisonné de la théorie du langage

(Langue, Linguistique, Communication) Paris: Classiques Hachette

Greimas (2012). Du sens, Paris, Seuil,

Groupe $\mu$ (1982). Rhétorique générale, Éditions du Seuil

Guattari, Félix (1977). La révolution moléculaire

Hamon Philippe (1972). „Pour un statut sémiologique du personnage” in Littérature, ${ }^{\circ} 6$, p.

Harré, Rom (1994). Érzelem és emlékezet: a második kognitív forradalom, Emotion and

Memory: The Second Cognitive Revolution. Kézirat. A tanulmány a Collegium

Budapest meghívására 1994. május 30-án The second cognitive revolution címmel elhangzott előadás módosított változata. Elérhető:

http://www.c3.hu/scripta/replika/25/harre.htm Letöltés ideje: 2019. 12. 09.

Heller Ágnes (2003). Filozófiai labdajátékok, Gond-Palatinus, Budapest

Herschberg-Pierrot, Anne (1993). La stylistique de la prose, Paris, Belin

Jakobson, Roman (1982). A költészet grammatikája, ford. Albert Sándor, Budapest, Gondolat

Jarrety, Michel (2003). La Poétique, PUF Elérhető: https://www.cairn.info/la-poetique--

9782130533030-page-3.htm Letöltés dátuma: 2019. 07. 05.

Jolles, André (1972). Formes simples, Paris, Seuil

Jong, Martin (1994). Le Présent du passé: Essais de littérature comparée, Presses 
Universitaires,

Namur,

Elérhető:

https://books.google.hu/books?id=RnqM8nnoaYAC\&printsec=frontcover\&redir_esc= $\mathrm{y} \# \mathrm{v}=$ onepage\&q\&f=false Letöltés ideje: 2019.11 .16$.

Jouve, Vincent (1992). „Pour une analyse de l'effet-personnage” in Littérature, n85, 1992. p.

103-111; Elérhető : $\quad$ https://doi.org/10.3406/litt.1992.2607 ;

https://www.persee.fr/doc/litt_0047-800_1992_num_85_1_2607 Letöltés ideje: 2019. 07. 20.

Jouve, Vincent, La poétique du roman, Paris, Sedes, 1997.

Kerbat-Orecchioni Catherine (1982). „Le texte littéraire: non-référence, auto-référence, ou référence fictionnelle" in Texte, 1 , Toronto, Trinity College

Kerbat-Orecchioni, Catherine (1999). L'Enonciation. De la subjectivité dans le langage, Paris, Armand Colin

Konrád György - szerk. (1967). A francia új regény, Európa, Budapest.

Léal, Eugénia (2009). La Mise à mort du récit dans l'oeuvre romanesque de Robert Pinget, Peter Lang

Lee, Mark (1996). „Tropismes : le réel comme rythme de l'histoire” in Le rythme : littérature, cinéma, traduction Volume 29, numéro 1, été 1996. Elérhetö: https://id.erudit.org/iderudit/501143ar Letöltés ideje: 2020. 01. 04. „Le tropisme est rythme, l'endroit du réel sarrautien."

Lee, Mark (1996). „Tropismes : le réel comme rythme de l'histoire, Le rythme : littérature, cinéma, traduction", Études littéraires Volume 29, numéro 1, été 1996. Elérhető: https://id.erudit.org/iderudit/501143ar, Letöltés ideje: 2020. 01. 13.

Lévi-Strauss, Claude (1958). Anthropologie structurale. Paris, Plon.

86-110; Elérhető: https://www.persee.fr/doc/litt_0047-4800_1972_num_6_2_1957, Letöltés ideje: 2019. 07. 17.

Lévi-Strauss, Claude (1990). La Pensée sauvage. Pocket

Lukács György (2009). A regény elmélete, ford. Tandori György, Budapest, Gond, Elérhető: http://www.balassikiado.hu/BB/NET/Lukacs/1_9.pdf Letöltés ideje: 2019. 07. 16.

Maár Judit, Ádám Anikó (szerk). (1995). Nyelv, költészet, titok, Nemzeti Tankönyvkiadó

Maingueneau, Dominique (1993). Éléments de linguistique pour le texte littéraire, Paris, Nathan

Maulpoix, Jean-Michel. (2002), Le bout de la langue, A propos de Nathalie Sarraute, 
Elérhető: http://www.maulpoix.net/Sarraute.html (Letöltés ideje: 2019. 07. 06.)

Mauriac, François (1972). Le romancier et ses personnages, Le livre de poche, eredeti kiadás Edmond Jaloux előszavával: Buchet-Chastel 1933, Elérhető: http://lettres.acrouen.fr/francais/fx_gide/mauriac.html Letöltés ideje: 2019. 07. 15.

Mélice, Anne (2009). „Un concept lévi-straussien déconstruit : le bricolage”, Les Temps Modernes 2009/5 ( $\mathrm{n}^{\circ}$ 656), pages 83 à 98, Elérhető : https://www.cairn.info/revue-lestemps-modernes-2009-5-page-83.htmur, Letöltés ideje : 2020. január 20.

Milly, Jean (1992). Poétique des textes, Paris, Nathan, 1992.

Neumer Katalin (1995). Tévelygések a nyelv labirintusában, Budapest, MTA Filozófiai Intézete, Doxa Könyvek, p. 33-34.

Newman, B. (1976). Une Poésie des discours: essai sur les romans de Nathalie Sarraute. Paris : Droz

Nipaporn Tirasait (2007). „Nathalie Sarraute: Tropisms and the drama of logos” in Journal of Humanities 10.2. 2007.

Pinard, Ernest, „Procès de Madame Bovary: réquisitoire” in Flaubert, Euvres Elérhető: https://flaubert.univ-rouen.fr/oeuvres/mb_pinard.php Letöltés ideje: 2019. 07. 20.

Pivot, Bernard (1972). „Nathalie Sarraute a réponse à tous”, Le Figaro littéraire, $\mathrm{n}^{\circ} 1342$. Propp, Vlagyimir Jakovlevics (2005). A mese morfológiája, Bp., Osiris Raillard, Georges (2000). „Notes en marge d'un 'livre difficile': Portrait d'un inconnu" in Littérature No. 118. juin 2000. p. 35-42. Elérhető : https://www.jstor.org/stable/41704770?read-now=1\&seq=5\#page_scan_tab_contents, Letöltés ideje : 2020. január 18.

Ramond, M (1994). „Le déficit, l'excès, l'oubli” in Le Personnage en question actes De Université de Toulouse-Le Mirail, Séminaire d'études littéraires, Colloque, Presses Universitaires du Mirail - Toulouse, p. 141-151.

Ricardou, Jean (1967). Problèmes du Nouveau Roman, Paris, Seuil

Ricardou, Jean (1971). Pour une Théorie du Nouveau Roman, Paris, Seuil

Ricardou, Jean (1972) Nouveau Roman: hier, aujourd'hui (Colloque de Cerisy-la-Salle, 20-30 juillet 1971) Poche

Ricoeur, Paul (1984). Temps et récit, Paris, Seuil

Riegl, Alois (1989). A későrómai iparmüvészet ford. Rajnai László. Corvina, Budapest

Robbe-Grillet, Alain (1985). Le Miroir qui revient, Édition de Minuit

Robbe-Grillet, Alain (2013). Pour un nouveau roman, p. 192. Első kiadás: Éditions de Minuit 
1963. Elérhető:

http://lpbduby.fr/data/documents/alain_robbe_grillet_le_personnage_de_roman.pdf Letöltés ideje: 2019. 07. 15

Rykner, Arnaud (1988). Théâtre du Nouveau Roman. Paris: José Corti

Rykner, Arnaud (1991). „Entretien avec Nathalie Sarraute” in Nathalie Sarraute, Paris,

Rykner, Amaud (1991). Nathalie Sarraute, Paris, Éd. du Seul

Schaeffer, Jean-Marie (1997). „La stylistique littéraire et son objet” in Littérature $\mathrm{N}^{\circ} 105$.

Saporta, Marc (1984). „Entretien avec Nathalie Sarraute”, L’Arc, no. 95. 1984.

Sarraute, Nathalie (1953). „Interjú Gabriel d'Aubarèddel”, Les Nouvelles littéraires

Sarraute, Nathalie (1957). Tropismes, Paris, Éditions de Minuit

Sarraute, Nathalie (1959). Le planétarium, Paris, Gallimard

Sarraute, Nathalie (1963). Les Fruits d'Or, Paris, Gallimard, 1963.

Sarraute, Nathalie (1973). Planetárium, ford. Farkas Márta, Magvető, Budapest

Sarraute, Nathalie (1979). „Comment j’ai écrit certains de mes livres. Entretien avec Lucette Finas" $\quad$ Erudit $\quad$ https://www.erudit.org/fr/revues/etudlitt/1979-v12-n3etudlitt2211/500503ar/

Sarraute, Nathalie (1983). „Interjú François-Marie Banier-val”, Le Monde des livres

Sarraute, Nathalie (1986). Gyerekkor, ford. Pór Judit, Magverő, Budapest

Sarraute, Nathalie (1989). Tu ne t'aimes pas, Gallimard

Sarraute, Nathalie (1992). „À voix nue, cinquième entretien avec Danièle Sallenave”, France Culture, 26 mars 1992.

Sarraute, Nathalie (1995). Enfance, Paris, Gallimard

Sarraute, Nathalie (1996). „Roman et réalité” in Oeuvres completes, p. 1652.

Sarraute, Nathalie (1996). „La Littérature, aujourd'hui” in Euvres complètes

Sarraute, Nathalie (1996). „Roman et réalité” in CEuvres complètes

Sarraute, Nathalie (1996). „Forme et contenu du roman” in Cuvres complètes

Sarraute, Nathalie (1996). „Le Langage dans l'art du roman” in Euvres complètes

Sarraute, Nathalie (1996). „Ce que je cherche à faire” in Euvres complètes, Paris, Gallimard

Sarraute, Nathalie (2006). Egy igenért vagy egy nemért, ford. Horváth Andor, Kolozsvári Állami Színház

Sarraute, Nathalie (2011). Tropizmusok, részletek, ford. Lombár Izabella, in Tiszatáj, 2011.

Sauvagnargues, Anne (2005), Deleuze et l'art, Paris, PUF. 
Sauvagnargues Anne (2015), „Deleuze et les cartographies du style. Asignifiant, intensif, impersonnel” in Adnen Jdey (szerk.), Les styles de Deleuze, Paris, Les Impressions Nouvelles, p. 157-181

Serreau, Geneviève (1959). „Nathalie Sarraute nous parle du Planétarium” in Les Lettres nouvelles, 29 avril 1959.

Simon Attila (2014). „Affekció és ítélet. Arisztotelész Retorikájának pathosz-fogalmáról” in Szenvedély, szerelem, narrációk. Filozófiai és pszichológiai tanulmányok, szerk. Boros Gábor, Pólya Tibor, Budapest, Eötvös Kiadó

Tadié, Jean-Yves (1984). „Un traité du roman” L’Arc n 95. 1984. p. 55-59.

Tison-Braun, Micheline (1971). Nathalie Sarraute ou la recherche de l'authenticité, Gallimard

Todorov, Tzvetan (1965). Théorie de la littérature, Paris, Seuil

Todorov, Tzvetan (1971). „Les hommes-récits” in Poétique de la prose, Paris, Seuil, p. 78-91.

Todorov, Tzvetan (1972). „Poétique” szócikk in Dictionnaire encyclopédique des sciences du langage (1972), Le Seuil

Todorov, Tzvetan (1978). Les genres du discours, Paris, Seuil.

Tomasevszkij, Borisz (2001). „Irodalomelmélet” in Bókay Antal - Vilcsek Béla (szerk). A modern irodalomtudomány kialakulása, Budapest, Osiris p. 268-287. "A hős" p. 281289.

Valéry, Paul (1937). Première leçon du cours de poétique, Elérhetö:

http://classiques.uqac.ca/classiques/Valery_paul/varietes/Lecon_1_esthetique_Var_V/1 econ_1_esthetique.html Letöltés: 2019.07.06.

Valéry, Paul (1957). Euvres complètes I-II. Paris, Gallimard

Verdrager, Pierre (2001). Le sens critique. La réception de Nathalie Sarraute par la presse, L'Harmattan

Zanoaga-Rastoll, Cristina (2016), „Les langues des tropismes chez Nathalie Sarraute”, Carnets 2016/7. Elérhető: https://journals.openedition.org/carnets/1062, Letöltés ideje: 2019. 11. 25.

Zéraffa M., Goldmann Lucien (1965). „Pour une sociologie du roman”. in Revue française de sociologie, p. 251-252; Elérhető: https://www.persee.fr/doc/rfsoc_00352969_1965_num_6_2_1915 Letöltés ideje: 2019.07.16.

Kép forrása: https://www.encyclopedia.com/literature-and-arts/literature-other-modernlanguages/french-literature/nouveau-roman Letöltés ideje: 2019. 11. 16. 


\section{Melléklet. Nathalie Sarraute: Tropizmusok (fordítás)}

I.

Mintha mindenhonnan szivárognának, a levegő enyhén nyirkos langyosságából nyílnának, áradásuk lassú szivárgásnak tünik a falakból, a berácsozott fákból, a padokból, a piszkos járdákból, a sugárutakból.

Hosszú sötét fürtökben nyújtóznak el a házak tünő homlokzatai között. Időről időre az üzletek tejüvege elött valamivel sürübb gócokat formáznak, mozdulatlanul, enyhe örvénylést keltve ezzel, akár valamely könnyed elzáródás.

Egyfajta különös csend, reménytelen elégedettség árad belölük. Figyelmesen nézik a Fehér Kiállítás mosodai ruhahalmait - hófödte csúcsok leleményes másolatait, vagy egy babát fogai és szemei rendszeres idöközönként felfénylenek, elcsitulnak, felfénylenek, elcsitulnak, felfénylenek, elcsitulnak, mindig azonos időmúlással felfénylenek újból és újból elcsitulnak.

Hosszan, mozdulatlanul nézik, ott maradnak, átadva magukat a kirakatüvegnek, mindig a következő időközre halasztva az eltávolodás pillanatát. És a nyugodt kisgyerekek türelmesen, mellettük várakoznak, s bár nékik adják a kezüket, fáradtan a nézéstől figyelmük elkalandozik.

\section{II.}

Elszakították magukat tükrös szekrényüktől, amelyben éppen arcukat vizsgálgatták. Felültek az ágyukban: „Tálalva van, tálalva van” - hangzott. Ő gyüjtötte össze a családot az asztalnál, mindegyikük a maga búvóhelyén lapult, tüskés-magányosan, a végkimerülés határán. „Mi van velük, hogy a szünni nem akaró fáradtság süt belölük?”, mondta, amikor a szakácsnéhoz beszélt.

Órákon át beszélt a szakácsnéhoz, ahogyan az asztal körül szorgoskodott, kitartóan serénykedett, könnyü fözeteket készítve nekik, némi harapnivalót, és beszélt, megkritizálva a látogatókat, a barátokat: „ennek és ennek a haja majd besötétedik, olyan lesz, mint az anyjáé, szögegyenes; szerencséjük van azoknak, akiknek nincs szükségük tartós hullámra”. „A kisasszonynak szép haja van”, harsogta a szakácsné, „sürü és szemet gyönyörködtető, még ha nem is csigás”. - „És ez meg az, biztos vagyok benne, hogy nem hagyott itt magának semmit. A smucigok, egytöl egyig mind smucig, van mibe aprítani, tele vannak pénzzel, felháborító. Mindent megvonnak maguktól. Én ezt nem értem!” - „Ó! Nem, mondta a szakácsné, nem, ezt 
nem viszik magukkal odaátra. És a lányuk, még mindig nem ment férjhez, pedig különösen helyes, bájos a haja, pisze az orra, kecses kis lábai vannak.” - „Igen, szép haja van, igaz, mondta, de senki sem szereti, tudja, nem valami vonzó. Ó! Ez igazán különös!”.

És, áradt a konyhából az alázatos és szutykos, toporgó gondolat, mindig egyhelyben járón, röghöz ragadtan, egyhangúan, körben forgón, körbe ingón; mintha megszédültek volna a gondolatok, mégsem tudnának megállni, vagy mindjárt felfordulna a gyomruk, mégsem tudnának nyugodni, mint mikor valaki lerágja a körmét, darabokban tépi le a hámló bőrt, majd vakarja a csalánkiütést, forgolódik álmatlan éjszakákon: olyan jólesik és annyira fáj, hogy valami mindig elfárad bennünk, még a lélegzetünk is elakad...

„De talán számukra ez mást jelentett.” Gondolta, midőn ágyán elnyújtózva hallgatta, ahogyan, ragacsos nyál, elméjük illata meglepheti, mintegy beborítva belülről is mindenét.

Semmit sem lehetett tenni. Nem volt mit tenni. Lehetetlenség volt elkerülni. Mindenütt, megszámlálhatatlan alakot öltve csap le, becsapós, akár a nappali fény („A nap ma oly becsapós, szólt a házmester, megtévesztő, az óvatlan ember ilyenkor könnyen elkaphat valamit. Akárcsak szegény uram, pedig szerette gyógyíttatni magát...”), mindenütt, az élet leple alatt, menet közben ér el, amikor futva haladsz el a házmester kabinja előtt, amikor felveszed a telefonod, családoddal ebéded költöd, barátokat hívsz vagy beszélsz valakihez, akárkihez.

Válaszolni kell nekik s lankadatlan bátorítani őket, kivált nem éreztetve velük, egyetlen pillanatig sem, hogy különbnek tartod magad tölük. Meghajolni, meghajolni és kiüresedni: „Igen, igen, igaz, természetesen”, ez az, amit mondani kell nekik, elfogadással, gyengédséggel teli tekintetet vetve rájuk, amely nélkül valami törés, valami szakadás, valami váratlan és vad dolog érhet, valami, ami még soha nem történt meg, és ami félelmes volna.

Úgy tünt, hogy ekkor, a tetterő és a hatalom elszabadult mámora őrjöngő erővel rázza meg őket, mint holmi öreg megrojtosodott mosogatórongyokat, csavargatná, tépve diribdarabjaira szálait... végleg megsemmisítve mindüket.

Ugyanakkor azzal is tisztában volt, hogy téves benyomás áldozata is lehet. Még mielőtt ideje lenne rájuk vetnie magát - biztos ösztönnel, az önvédelem gyorsaságával meg némi könnyed életerővel, amelyben az ő félelemkeltő erejük is állott, vele szembefordulnának, és egyetlen ütéssel, ezt nem pontosan értette, hogyan, de letaglóznák. 
III.

A Panteon mögötti nyugodt kis utcákba jöttek lakni, a Gay-Lussac vagy a Saint-Jacques utca oldalára, árnyas udvarokra nyíló, de mégis komfortos, módfelett helyénvaló lakásokba.

Ez kínálkozott itt a számukra; ez, és az a szabadság, hogy azt csináltak, amit akartak, úgy jártak, ahogy tetszett, akármilyen maskarában, akármilyen arccal, a szerény kis utcákban.

Semmilyen ruha viselése nem volt elvárás velük szemben, semmilyen másokkal együtt végzendő tevékenység, semmilyen érzés, semmilyen emlék. Védett és lecsupaszított létezés kínálkozott a számukra, olyan életforma, amely hasonlíthatott egy váróteremre valamely elhagyott külvárosi állomáson; tágas terem, szürke és langyos, fekete kályhával a közepén, fapadokkal a falak mentén.

És elégedettek voltak, tetszett nekik itt, majdhogynem otthon érezték magukat, jóban voltak a házmester asszonnyal, a tejessel; ruháikat a városnegyed leghigiénikusabb és legolcsóbb mosodájába vitték tisztíttatni.

Soha nem keresték az alkalmat, hogy emlékeiket felidézzék a vidékről, ahol annak idején játszottak, nem keresték a pillanatot, hogy újból megtalálják annak a kisvárosnak az illatát és színét, ahol felnőttek, soha nem látták lelki szemeik előtt, amikor városnegyedük utcáit rótták, amikor az üzletek üvegvitrinjeiben gyönyörködtek, amikor elhaladtak a házmester odúja elött, soha nem fedeztek fel emlékeik között egy-egy élettel elárasztott faldarabot, valamely udvar átható és simogató kőkockáit vagy egy peron gyengéd lépcsőjét, amelyen egyszer valaha gyermekkorukban ültek.

A lépcsőházukban időnként találkoztak ,az alsó lakóval”, középiskolai tanár, az iskolából jön haza két gyermekével négy órakor. Mindhármójuknak hosszúkás feje van, sápadt, sima és fénylő szemei, akár a nagy elefántcsonttojások. Lakásuk ajtaja egy pillanatra kitárul, hogy beengedje őket. Az ember láthatja őket, ahogyan a belépő padlójára helyezett apró filc lábtörlőkre lépnek - majd csendben távolodnak, becsússzanak az előszoba árnyas mélyébe.

IV.

A lányok alig megformált dolgokról csacsogtak, semmibe vesző tekintettel, mely mintha bensőleg egynémely finom és érzékeny, szinte közvetíthetetlen érzést követne.

Sürgette őket: „És miért? No, miért? Miért vagyok folyton önző? Miért csak magamnak való? Mondjátok meg, miért?" 
Valahol mélyen magukban tudták, miért, mégis játékot üztek, eleget téve valamiféle noszogatásnak. Néha úgy tetszett, mintha szünet nélkül egy tőle elválaszthatatlan pálcát követnének nyomon, amely úgy mozgatta, irányítgatta öket, gyengéden úgy billegette, hogy engedelmességre bírja mindőjüket, mint rongybabákat a balettmester. Jó, jó, táncolnak egyet, majd perdülnek-fordulnak, némi lelket, néminemü értelmet adva a sejtelemnek, ám mintegy érintés nélkül, anélkül, hogy arra a titkos mezsgyére tévednének, amelyet eltiltott tőlük, kivívva ezzel nemtetszését.

„És miért? Aztán meg miért? Mire jó ez?” Rajta hát! Bátran! Nem, nem így! Vissza, vissza! Ó igen, derüs hangnem, igen, még, selymesen, spicc, kedélyesség és irónia. Igen, igen, meg lehet kísérelni, kezd is hatni. Most ártatlan arcot, hogy súlyosnak tünő igazságokat merjenek hangoztatni, hogy foglalkozzanak vele, rajong ezért, és csipkelődni vele, imádja ezt a játékot. Ó, jaj! Vigyázat, finoman, finoman, kezd veszélyessé válni, de meg lehet kísérelni, tán sikamlósnak, szórakoztatónak, kihívónak találja majd. Máris bontakozik egy történet, botrányokkal teli, emberek magánéletéről, akiket valaha ismert, kik vendégül látják még, megbecsülik. Ez már jókedvében találja, vonzódik az efféléhez... De nem! Jaj! Örület, nem érdekli az egész, vagy nem tetszett neki: hirtelen elhúzza a száját, milyen félelmes ilyenkor, morózus, zsémbelődő, lehordja őket a sárga földig, megalázóan ordít velük, tudtukra hozva (még nem sejtik, miképp) alantas voltukat, ha most nem is, de az első adandó alkalommal, anélkül, hogy válaszolhatnának neki, s mindezt az ő rossz, kíméletlen stílusában.

Ó istenkém, mi kín! Micsoda erőfeszítés, keserves fáradság jár a szüntelen szökdécseléssel, őelőtte: majd hátra s előre, megint hátra, mostan forgás körülte és spicc, a tekintet csak rajta lehet, aztán oldalra forgás, homlokegyenest hátra, újra előre, majd hogy meglegyen újfent az öröme.

V.

A júliusi hőség napjaiban a szemben málló tüzfalról élénk gyémántfény zuhogott az aprócska nedves udvarra.

E hőség alatt ür volt és csend, mintha felfüggesztették volna az elevenséget; egyedüli zajként a keramitkövek zúgolódása volt észlelhető, a rajtuk húzódó karosszék agresszív, fülsértő csikorgása, majd egy távoli ajtó becsapódása. És ebben az elviselhetetlen melegben, e csöndtörténésben - mint hideg áramlás vált ki a leszakadó zaj. 
És a lány mozdulatlanul maradt az ágya szélén, a lehető legkisebb helyet foglalva el, feszülten alélt, mintha azt várná, hogy valami robbanni készül, lesújt rá e fenyegető csendözönben.

Néha a napsütésbe dermedt halottmerev réteken a tücskök éles ciripelése visszhangozza így a magány jéghűvös érzetét, a jövőt feszítő szorongás, karnyújtásnyira a gyűlölettől, így lepi meg az elhagyottat.

Elnyújtózás a füben, a perzselő nap alatt - mozdulatlan megmaradás, figyelmes várakozás.

A bejárati ajtó zárjában fordult a kulcs, zaja neszez, mintha a folyosók hosszán elnyúló megfakult festés és a kék csíkos öreg tapéta hozta volna, átszivárog a lány csendjébe. Hallotta, ahogyan csapódik a dolgozószoba ajtaja.

Ottmaradt, összekucorodva, várakozón, minden mozdulat nélkül. Elmenni a fürdőszobába kezet mosni vagy folyatni a csapvizet bántónak tünt, a legkisebb cselekedet ötlete is úgy merült fel, mint ugrás a mélybe, vakmerő tett. A víz zubogása a felkarolt csöndben olyannak tetszett volna, mint egy feléjük intő hívogatás, érintkezésre szólító jeladás, viszolyogtató, akárha egy pálca végével valamely medúzát érintenénk, és vegyes undorral várnánk, amikor az összerándul, mozdulni kezd és kinyílik.

A lány csak érezte őket, mint a moccanatlanságot meg az ugrásra kész vacogást a falakban.

Nem rezzent. És körülötte a ház, az utca úgy tünt, bátorítja erre, természetesnek tüntetve fel ezt a halk mozdulatlanságot.

Amint az ember kinyitja az ajtót és meglátja a lépcsőt, szíve telve szenvtelen, személytelen és színtelen nyugalommal, a nyurga lépcsőt, amely a rajta áthaladó emberek lépteiből, itt jártuk legkisebb emlékéből szemlátomást mit sem őriz meg, amint az ebédlő ablaka mögé kucorodunk fürkészni a házak homlokzatát, az üzletsorokat, az idősödő nőket, az aprónépséget, mely az utcán sokasodni látszik, akkor bizonyosnak az tünik, hogy a lehető legtöbb időre van szükség - a várakozásra, a mozdulatlan maradásra, a semmit sem tevésre ; hogy a legvégső megértés, az igaz értelem evvel lepjen meg - semmibe nem belefogni, a lehető legkevesebbet mozogni, mit se tenni.

Legfeljebb arra van mód, hogy vigyázva, senkit nem felébresztve, óvatos észrevétlen, oda se pillantva leereszkedjük a homályos lépcsőn és majd visszafogott haladással a járdán, a falak mentén, csak hogy némi levegőhöz jussunk, egy csepp mozgás érjen, jóleső zsibbadás az 
elgémberedett végtagjainkban, nem tudva, hová, de nem is vágyva arra, hogy bárhová is tartsunk, visszajöjjünk, ide haza, leülvén az ágy szélére és újból várjunk, befelé hallgatózva, némán.

VI.

Reggel az asszony roppant korán kelt, keresztül-kasul száguldott a lakásban, keserü kiáltás, dühös jajszó, készülődő ,jelenet” nyomta-feszítette. Szobáról szobára járt, bekukkantott a konyhába, haragos noszogatás a fürdőszoba ajtaján, azt éppen elfoglalták, ő kész volt arra, hogy közbelépjen, rájuk ripakodjék, kijajveszékelje őket, vagy hogy megkérdezze tőlük, maradnak-e még egy órát, emlékeztetett, hogy későre jár, le fogják késni a villamost, a vonatot és már túl késő lesz, s mindez köszönhető a hányaveti nemtörődömségüknek, az ebédjük is tálalva, vagy már ki is hült, mindenestre két órája készen van, mindjárt megdermed... Úgy tünt, a szemében semmi sem annyira megvetendő, mint inkább buta, gyülöletes, rút s az alacsonyabb rendűségnek, gyöngeségnek sincs nyilvánvalóbb jele, mint hogy valaki hagyja elhülni, megbörösödni a levesét.

A beavatottak, a gyerekek, sietősre fogták a tempót. A többiek, a gondtalanok, akik nem törődtek az efféle földi hívságokkal, nem ismerték azok hatalmát ebben a házban, udvariasan válaszolták lágy természetességgel: „Ó köszönöm, ne aggódjék, szívesen iszom hidegen is a kávét." Ezeknek az idegeneknek nem mert semmit sem mondani, s ezért e nyájas hálálkodásért, ezekért az udvarias mondatokért, amelyek finom nemtörődöm szófukarsága kezük egy legyintésével inkább hárította közeledését, mint hogy tekintetbe vette, vagy akár egy pillanatra is valamire méltatta volna - csupáncsak ezért gyülölni kezdte őket.

Használati tárgyak! tárgyak! Ereje forrásai. Hatalma ezekben rejlik. Ezt vetette be a maga ösztönös, tévedhetetlen és magabiztos módján, hogy győzelemre törjön, teljes megsemmisítésre.

Amikor valaki a közelségében él, a rutin fogságának jármába hunyászkodó bús rabszolga, akkor nehézkes lesz, mint akit tárgyak nógatnak, hajszolnak.

Kéznél lévő tárgyak. Dolgaink. Csengetések. Nem lehet nem figyelembe venni. Emberek, akiket nem lehet megváratni. Úgy él velük, akár egy falka kutyával, mely minden pillanatukban rájuk vicsorít: „Csöngetnek! Siessenek, gyorsan, hamarjában, várják magukat.”

Még akkor is, amikor bezárkózva meglapulnak a szobájukban, kiugrasztja őket: „Hívják magokat. Nem hallják? Csöng a telefon. Nyílik az ajtó. Huzat van. Nem csukták kilincsre az 
ajtót, a bejárati ajtót!” Becsapódott egy ajtó. Csattant egy ablak. A szobát fuvallat szelte. Sietni kellene, iparkodva, megszidottan, toszigálva el mindent az útból, szorongón, mindent hátra- és meghagyva, rajt, igyekezvén a szolgálatra.

\section{VII.}

Főleg ne előtte, csak őelőtte ne, majd később, amikor nem lesz itt, csak most ne. Különösen veszélyes volna, illetlen erről beszélni előtte.

Az asszony lesben állt, közbelépett, hogy a férfi semmit ne halljon meg, maga kezdett beszélni szüntelen, igyekezvén elvonni a figyelmét: „A válság... és a folyamatosan emelkedő munkanélküliség. Ez magától értetődő, egész világosnak tűnt, aki annyira jól ismerte az életet... De a felesége nem tudta... Noha neki is a tudomására hozták... Ám a férfinak igaza volt, amikor valaki belegondol, minden annyira nyilvánvalóvá válik, annyira egyszerűvé... Érdekes volt vagy inkább siralmas látni annyi egyszerü ember naivitását.” Minden jól ment. Elégedettnek tünt. Jóindulattól sugárzóan, önbizalommal telve, teáját kortyolgatva magyarázott, és néha hallhatóan arcát beszívva, nyelvét hátulról oldalsó fogainak vetve, jellegzetes, már-már sípoló zajjal igyekezett némi ebédmaradékot eltávolítani - e hars nyammogás lényének mindig valamiféle elégedett, gondtalan árnyalatot kölcsönzött.

Ám időnként, vendéglátójának minden erőfeszítése ellenére, csend ült közéjük. Valaki az asszony felé fordulva, megkérdezte, elment-e a Van Gogh-ot megtekinteni.

„Igen, természetes egyszerüséggel ment el megnézni a kiállítást (semmi sem történt, biztosan észre sem vette, semmi sem történt, elhessegette magától a gondolatot), azoknak a vasárnap délutánoknak az egyikén ment el körbejárni, amikor az ember nem tud magával mit kezdeni. Kimondottan jó volt.”

Elég, most már elég, valahogy meg kellene őket fékezni, ezek az emberek nem érzékelnek semmit sem, nem látják, hogy itt van és mindent hall. Az asszony félt... ám nem törődtek vele, folytatták.

Hát jó, ha ennyire ragaszkodnak hozzá, mivel nem tudja őket visszafogni - hagyjuk, hogy elszabaduljanak. Az ő bajuk, hát lépjenek be egy pillanatra, Van Gogh, Utrillo vagy bárki más. Eléjük állt, hogy megpróbálja kicsit maszkírozni őket, hogy ne közelítsenek annyira, vagy a lehető legkevésbé sem, oda, finoman szólva oldalt álljanak, engedve, a fal mellé. Jó, jó, semmi nem történt, már nyugodtan nézhetik őket: Utrillo részeg, épp most jött ki a Szent Annából és Van Gogh... Jaj! Már számtalanszor dugta a férfi orra elé, ő pedig soha nem 
találná ki, mit tarthat Van Gogh abban a papírcsomagban. Abban a papírban... a levágott fülét tartotta! „A levágott fülü férfi”, valóban, tudta, miről van szó? Már mindenhonnan ez köszön vissza. Ennyi. Ez minden. A férfi nem bosszankodott? Nem kelt föl, lökte el durván a nőt, hogy rájuk taposson, elvesző, szégyenteljes pislogással, ocsmányul visszahúzott ajkakkal?

Nem, nem, az asszony alaptalanul aggódott. A férfi nagyon jól értette. Jóindulatú volt és engedékeny. Hallatta arczacskója beszívott sípoló cuppogását, és továbbra is látható volt a tekintete mélyén az a vidám visszatükröződés, az a fel-feltörö fény, amely a bizonyosság érzésének, e kedves elégedettségnek nyilvánvaló kifejeződése volt.

VIII.

Amikor a fiatal és üde lüktető élet érintette, ártatlan hamvasság, akkor fájdalmas és ellenállhatatlan kényszer fogta el, hogy ideges ujjaival érje és tapintsa, majd minél közelebb vonja magához, szinte bekebelezze.

Némelykor úgy esett, hogy kimozdult valamelyikükkel, elvitte egyiküket sétálni, erősen szorította magához, ahogy haladtak át az úttesten, az aprócska kezeket meleg ragaszkodó tenyerében, pedig vissza is fogta magát valamelyest, nehogy agyon tördelje a vékonyka ujjakat, mialatt haladt át, végtelen óvatossággal eszmélt először jobbra, majd balra, hogy megbizonyosodjék, van-e idejük átiszkolni az úttesten s hogy jól lássa, felelősséggel betelten, nem jön-e autó, mely az ő parányi kincsét, dédelgetett kicsinykéjét, e lágy és ősbizalommal teli lüktetést elüthetné.

Az áthaladáskor megtanította arra, hogy hosszan várakozzon és éberen figyeljen, vigyázzon, vigyázzon és feszülten figyeljen, az utcán, a zebrán való átkelés során, hiszen „olyan semmiség is, mint egyetlen másodpercnyi lankadás elég lehet ahhoz, hogy bekövetkezzen a baleset".

Imádott nekik beszélni hajlott koráról meg haláláról. „Mit fogsz szólani, amikor nem leszen többé nagyapád, nem lesz többé néked, merthogy öreg, oly öreg szegény, nemsokára eljön érte is a mogorva vén. Tudod, mi leszünk már mi odaát? A te papádnak is volt anyukája. Ó, jaj! Hol van már az ő anyukája? Jaj! Hol van, szívem? Eltávozott. Nincs már neki rég. Meghalt egyszer, elment ő is, nincsen többé, elköltözött.”

Az illattalan levegő megkövült szürkeségben gomolygott, a házfalak az utca mindkét oldalát oldva magosba keltek, mígnem körülölelték őket a mérges köddé nőtt falak - lassan haladtak a járda hosszán, kéz a kézben. A kicsire zsibbasztó tompa nyomás nehezedett. Gyöngéden 
szigorú, kérlelhetetlen erőszakot véve rajta alaktalan és fojtogató pépet nyeletnek vele, még orrát is befogják - ó, issza már, átadva magát a beletörődésnek, míg csendes illedelmesen, bólogató jóhiszeműen üget nagyapja nyomába iramodva, engedelmes tisztelettel adva újra csak kis kezét, helyeslőleg, miközben magyarázzák, hogyan kell mindig minden óvintézkedést betartva átkelni, először jobbra, majd balra vetve pillantást, megfigyelni, feszült éberen, elébb félni, mint megijedni, míg át nem érünk.

IX.

A lány összegömbölyödve ült a fotel sarkában, megfeszített nyakkal, kimeredt szemekkel vonaglott: „Ó igen, igen, igen, igen” - mondta, és egy-egy főbiccentéssel hagyta helyben valamennyi mondattöredékét. Ijesztő volt, légies és puha, csupa bársonyosság, csak a szemei dülledtek ki. Volt benne valami fenyegető, feszültséget keltő, bája vészjóslón lengte be.

A fiú érezte, mindenáron fel kellene ráznia, meg kellene nyugtatnia, de erre csak olyan valaki lenne képes, akinek emberfeletti ereje van, valaki, akinek lenne annyi bátorsága, hogy szemtől szemben volna vele, ott, ültő helyében, jól megtámasztva magát egy másik fotelban, aki merné vizslatni őt nyugodtan, egyenesen a szemébe, elkapva a tekintetét, nem fordulna el vonaglásától. „Nohát, hogy vagyunk s miként?” - merné nekiszegezni. „Vagyogatunk, vagyogatunk?” - vetné fel megszólítva őt, majd várna. Várná, hogy szóljon, hogy cselekedjen, hogy mindent fedjen föl, hogy kiadja magából, már-már kirobbanón - s nem félne tőle.

De neki soha nem lenne ehhez ereje. Így hát kénytelen volt elérni, hogy magában tartsa mindazt a lehető legtovább, akadályozni - nem ébredhet rá, nehogy egyszer feltörjön belöle, mindenáron, mindegy, mi módon, de a jó, ha teste magába zárja.

De mit? Mi is ez? Fél, meg fog örülni, nem veszíthet egyetlen pillanatot sem, észnél kell lennie minden másodpercben, öntudatánál. És, mint mindig, amint találkoztak, abba a szerepbe kényszerült, amelybe erőnek erejével, fenyegetéssel, úgy tetszett, a lány taszította. Beszélni kezdett, szüntelen, mindegy kiről, mindegy, miről, keringett körös-körül, rajt (akárcsak a kígyó tekereg zenére? Ahogy a madarak a boa előtt? Nem, nem tudni), gyors hevületben, megállás nélkül, nincs veszteni valónk, lóduljunk, amíg van némi ráhatás, puhítsuk. Miről? Kiről? Magáról, az övéiről, a barátairól, a családjáról, apró dolgaikról, napi gondjaikról, titkos harcaikról, mindarról, amit érdemes lenne inkább takargatni, ám minthogy mindez talán érdekelhette $\mathrm{s}$ mivel elégedettséggel tölthette el, nem volt mit tenni, el kellett 
mondani, suttogva neki mindent, lemeztelenedvén, mindent odavetve elé, mindaddig, amíg itt lesz a fotel sarkában összegömbölyödött, légies puha vergődéssel.

$\mathrm{X}$.

Délután együtt töltötték szabadidejüket, a fiatal nők életét élték. Ó, mily csodás volt ez az élet! A teázókba mentek, kéjes pillantásokkal gondosan kiválasztott süteményeket fogyasztottak: képviselőfánkot, mazsolás kuglófot, gyümölcstortát.

Körülöttük tarka vidáman csipogó madárház, langymeleg, világosság és cicoma. Sokáig maradtak így, csacsogón összeszorultak, egymás vállát támasztották apró asztalaik körül.

Nyugtalan élénkség, lágy, örömteli izgalom áramlott köztük, kétkedés-utóízü nehéz döntés emlék-iramai (vajon illenének-e egymáshoz a kék és a szürke együttes? ám de mégis, oly helyesek lennének együtt), majd az átformálódás lehetőségének távlata, személyiségük örömteli felragyogásának előszele.

Lányok, lányok, tünde lányok, mindig ők, telhetetlenek, csiripolón finomselymüsek.

Arcuk némi belső indulattól ragyog, érdektelen tekintetük a külcsínre réved, a dolgok lényegét leplező küllemre, felméri egy pillanat alatt (szép-e vagy rút?), majd ejti a fonalat. Élesen villant az arcra kent festék, a sivár frissesség.

A teázókba tartottak. Ott maradtak órákon át, míg semmibe olvadtak a hosszú délutánok. Ömlött belőlük a szó: „Gyászos jelenetek zajlanak közöttük, semmiségeken civódnak. Ám muszáj azt mondanom, inkább a férfit sajnálom. Mennyi? Legalább kétmillió. Ha mást nem is veszünk, mint a Bébi néni örökségét... Nem... Hogy képzeled? Nem veszi el! Neki egy házias nő való, de ezt maga nem képes felmérni, én mondom. Egy házias nőre van szüksége... Családszeretőre... Háziasra...” Mindig mondták nekik. Ezt rágták a szájukba, s tudták: az érzelmek zajlása, a szerelem meg a múló élet a felségterületük. Ezek hozzájuk tartoznak.

Szóval tartották egymást, ugyanazon dolgokat ismételgették, fonákjukra hajtogatták, ki-be fordítgatták, egyik oldalról a másikra, dagasztották, dagasztották, ujjaikkal szüntelen gyúrták az életből kivont szegényes és terméketlen pépet, (már amit ők „életnek” neveztek, a felségterületüket) nyújtva mindaddig, míg ujjaik között csomócskákká nem silányultak, amolyan szürke galacsinokká. 
XI.

A lány megértette a titkot. Kiszimatolta, hol rejtőzik, ami mindnyájunk valódi kincse. Ismerte ugyanis az ,értékek rendjét”.

Elötte nem folyhatott társalgás a kalapformákról és a Rémond márkájú ruhaanyagokról. Ugyanakkor nem rokonszenvezett a négyszögletes orrú cipőkkel.

Akár egy pincebogár, alattomosan kapaszkodott feléjük és fedte fel fondorlatosan a rejtve maradt titkokat, akár egy macskakölyök, amelyik a szája szélét nyalogatja és behunyja szemét, ha már kiszagolta az eldugott tejfeles bödönt.

Mostanra övé volt a felismerés. Nem ereszti. Öröméböl nem billenthette ki semmi. Fanyar élvhajhász hallgatózás, falánk fülelés. Semmi sem kerülhette el a figyelmét, ami hozzájuk tartozott: képkiállítások, újonnan megjelent könyvek... Mindenről volt fogalma. Mindig az „Évkönyvvel” kezdte, mostanában érdeklődése Gide felé fordult, nemsokára mohó megigézettséggel fog szorgos jegyzetelésbe a Szövetség az Igazságért ülésein

Mindezen gond nélkül végigtrappolt, mindenhová eljutott, minden mögé bekukucskált megemelve majd' mindent szögletes körmeivel; s amint úgy rémlett neki, valahonnan erről hall sejtelmes hangokat, tekintete újra kigyúlt és nyugtalanul nyújtogatni kezdte a nyakát.

Kimondatlan utálattal viseltettek iránta. Elrejtették volna - gyorsan - érintése elöl, menekítették és eloldották volna megszégyenítő jelenlététől... Ám kijátszotta őket, mindenről volt tudomása. Nem lehetett elvonni a figyelmét a chartres-i katedrálisról. Olvasott róla sokat. Azt is, mit gondolt róla Péguy.

A legtitkosabb sarkokban, a dugdosott, rejtve örzött kincsek között keresgélt mohó ujjaival. Mindent, mi „,intellektuális”. Erre volt szüksége. Neki, magának. Öneki, mert már tudta igazán, mi mit ér. Kellett neki az, ami intellektuális.

Nagy számban voltak olyanok, mint ő, kiéhezett és kíméletlen paraziták, a frissen megjelent írásokra ragadó piócák, mindenüvé nyúló meztelen csigák, megfolyt nyáluk habzik Rimbaud rejtelmein, Mallarméból kiszívják az élet-nedveket, egymás hegyén-hátán a visszataszító megértés, ragacsuk Ulyssesen vagy a Malte Laurids Brigge feljegyzésein

„Oly beh szép”, búgta lágy indulatban, s ihletett, tisztán ragyogó arccal emelte tekintetét, amelyben az ,istenség egy szikrája” lobban. 
XII.

Kedvét lelte a College de France-ban tartott rendkívül népszerü előadásaiban.

A hivatásosok gesztusainak emelkedettségével, szakértő és kíméletlen kézzel, élvezettel vájkált Proust vagy Rimbaud rejtőző életében, figyelmes hallgatósága szeme elé tárva titkaikat, misztériumukat, ahogyan ő magyarázta: „esetüket”.

A szeme sem állt jól, tekintete átható volt, a nyakkendője: mintha skatulyából húzták volna elő, gondosan négyszögletüre kerekített szakállával megszólalásig hasonlított a reklámokban látható statiszta Úrra, aki mosolyog és feltartja az ujját: Saponite - a kiváló mosópor, az eszményi Salamandre: gazdaságosság, biztonság és kényelem.

„Nincsen ebben semmi különös - latolgatta -, láthatják, jómagam is meggyőződhettem róla, hogy nincsen porhintés, nincs semmi, amit ne tanulmányoztam volna át tüzetesen, ne soroltam volna be valamely kategóriába, ne láttam volna el lábjegyzetekkel.

Nem hozhatják magukat zavarba. Tessék, itt rejtem őket, a kezemben, itt vannak, ni, akár a pucér és kucorgó gyermekek, önöknek mutatom, hogy elférnek a tenyeremben, mintha alkotójuk lennék, az apjuk, kiszolgáltattam, megfosztottam őket varázsuktól, titokzatosságuktól, addig hajszoltam és üldöztem bennük mindazt, ami csodaszámba ment.

Immár alig különböznek a fura és különleges intellektusú, már-már mulatságos pojácáktól: megkeresnek és vég nélküli történeteket mesélnek, hogy időt és törődést nyerjenek tőlem, becsüljem valamire, megnyugtassam öket.

Nem fogják tudni felkavarni önöket, ahogyan a lányaimat sem ejti rabul különös indulat, mikor fogadják barátnőiket az anyjuk szalonjában: kedves trécselésbe fognak és nevetgélgetnek, mit sem adnak arra, mit mondok pácienseimnek a szomszédos helyiségben.”

Így pallérozta azt a sok elmét a College de France-ban. És mindenütt máshol, a környékbeli egyetemeken, az irodalmi, jogi, történelmi és filozófia tanszékeken, az intézetben és a palotában, az autóbuszon és a metrón, a hivatalokban: a rendes és normális életvitelü ember, az aktív szellemü ember, a méltóságát mindig megőrző és egészségesesen élni tudó ember, az erős akaratú, ki győzedelmeskedni képes.

Az életből kiszakított Rimbaud és Proust pedig a szép tárgyakkal megrakott butikokat, a magukat fürgén csipkedő nőket, a kávézó pincéreit, az orvostanhallgatókat, a rendőröket, a hivatali írnokokat nagy ívben elkerülik; az életen kívülre lökötten, támasz és cél nélkül 
bolyonganak az utcák hosszán át vagy a mellkasukra ejtett fejjel, bútól aszottan gubbasztanak valamely poros téren.

XIII.

Láthattuk őket, ahogy a kirakatok mentén gyalogoltak, túl egyenes felsőtestük enyhén előre görbedt, merev combjuk épphogy terpeszben, és kis kajla lábuk a nagyon magas tüsarokkal csattogva aszfaltot ér.

Karjuk alatt tartott táskájukkal, kesztyüjükkel, előírásos, a fejükön decensen billegő kis „,bibijükkel”, kidudorodó szemhéjukba szúrt hosszú és merev szempilláikkal, szigorú szemeikkel lótottak-futottak a butikok mentén, hirtelen megtorpantak, mohó és mindentudó tekintetük fürkésző volt.

Igen hősiesek s kitartóak voltak, ahogyan több napja rohantak már üzletről üzletre, „egy kis sportkosztüm” nyomában, mintás tweed anyagból, ,afféle apró mintás, tudja, miről van szó, szürkés és kék kockás... Jaj, nincs belőle maguknál? Hol találhatnék ilyent?” Majd folytatták a rohanást.

Az a kis kék, az a szürke kosztüm... Nyugtalan szemük kutatva mustrált... Lassan egyre erősebben magához ragadta, kényszerítően fogva tartotta őket, elengedhetetlen tartozékká vált, önmagában való célnak tünt fel, többé nem tudták, miért, megragadása minden árat megért.

Talpaltak, gyalogoltak, kutyagoltak bátran (többé semmi meg nem állíthatta őket) árnyékos lépcsőkön, a negyedik vagy az ötödik emeletre, „olyan angol tweedre szakosodott üzletekbe, ahol biztosan lehet afféle látványosat találni”, és tán egy kicsit idegesen (elfáradva, hamarosan türelmüket vesztve), könyörögtek: „De nem, ó nem, hisz jól tudja, mit akarok mondani, amolyan kockás, keresztbe csíkos... de nem, nem ez, egyáltalán nem ez... Jaj, nincs maguknál? De hol találhatnék? Már mindenütt néztem... Talán ott gondolja? Jó, elmegyek, megnézem... Viszontlátásra... Ó, jaj, igen, mennyire sajnálom. Mégis mosolyogtak, szeretetre méltóan, jól nevelten, mint akiket erre hosszú évek óta idomítanak, mikor még az anyjukkal róhatták útjukat, együtt tervezgették, hogy csinosak és elragadóak legyenek ,szinte a semmiből”, ugyanis már egy fiatal lánykaformának annyi mindenre van szüksége, és tudnia kell gondoskodni magáról”. 
XIV.

Bár mindig hallgatott és félrevonult, szerényen hajlott meg, halkan számolva a szemeket, két szem sima, most három fordított, és most egy egész sor sima, annyira nőiesen, lágyan simult bele a környezetbe (ne is figyeljenek rám, nagyon jól vagyok így, ahogy vagyok, semmit nem kérek magamnak), mégis szüntelenül érezték, mint a húsuk egy érzékeny pontját, a jelenlétét.

Mindig ő volt a figyelmük középpontjában, mint akiket megbabonázott, félelemmel vegyes aggodalommal felügyeltek minden szót, a legjelentéktelenebbnek tünő hanglejtést, a legkisebb apróságot, minden mozdulatot, minden tekintetet; lábujjhegyen közeledtek, a legkisebb zajra visszarettentek, hiszen tudták, hogy mindenütt titokzatos helyek tárulhatnak fel, veszélyes zúgok, amelyeket nem szabad érinteni, körbe tapogatni, különben a lehető legkönnyedebb érintéstől is az a sok-sok harangocska, akár egy Hoffmann-mesében, ezer, szüzies hangjára emlékeztető, tiszta csengőszavú bimbamocska - kezd el csilingelni.

De néha nap, az elővigyázatosságból tett lépések, az erőfeszítések ellenére, amikor látták, hogy csendesen ült a lámpa alatt, akárcsak egy törékeny és finom, mozgékony tapadókorongokkal borított mélyvízi növény, érezték, hogy megcsúsznak, hogy teljes súlyukkal zuhannak és mindent összetörnek maguk alatt: ez belőlük jött, a buta tréfák, a röhögőgörcsök, az ocsmány emberevős meseszólamok, mindez kijött belőlük, és robbant anélkül, hogy vissza tudták volna tartani. Ö pedig csöndesen visszahúzódott - ó, ez túl szörnyü! -, belakott szobácskájára gondolt, drága menedékére, ahová hamarosan visszavonul majd, és letérdepelhet az ágya mellé, a nyak körül fodros, oly gyermekies fátyol hálóingében, meghitten, akár kis Lisieux-i szent Teréz, Szent Katalin, Blandina... és, a kezében szorítva a nyakában függő aranyláncocskát, imádkozhat a büneikért.

Néha, amikor minden jól ment, s kacéran már-már bevackolta volna magát közéjük, érezvén, hogy egy általa annyira kedvelt és óhajtott súlyos témában kezdtek őszinte beszélgetésbe, amazok bohóc piruettet hajtottak végre s arcukat őrült, szörnyü mosoly feszítette szét.

XV.

A lány annyira szerette a vendégségbe érkező idős urakat, akikkel lehet társalogni, akik annyira átlátják a dolgokat, akik ismerik az életet és annyi érdekes emberrel találkoztak már (tudta továbbá, hogy az, aki most jött hozzájuk, Félix Faure barátja volt, és hogy megcsókolta Eugénia uralkodónő kezét). 
Amikor a férfi a szüleihez jött vacsorázni, gyerekesen és tiszteletteljesen viselkedett (hisz az illető egy tiszta tudós alkat volt), kissé félszegen is, de várakozó izgatottsággal (tanulságos lenne hallani fiatalos véleményét), elsőnek ment le a szalonba, hogy a társaságába szegődjön.

Kínosan kelt fel: „Nahát, maga itt! Nos, hogy vagyunk? Mivel foglalkozik mostanában? Mivel tölti a drága idejét? Ja, hogy még visszatér Angliába? Ó, igen?”

Visszamegy. Valóban, annyira szereti ezt az országot. Az angolok, amikor az ember megismerni öket...

Ám ő félbeszakította: „Anglia... Ó, igen, Anglia... Shakespeare? Igaz? Nem igaz? Shakespeare. Dickens. Emlékszem, kicsi lány, amikor fiatal voltam, azzal szórakoztam, hogy Dickenst fordítottam. Thackerayt. Ismeri Thackerayt? Th... Th... Valahogy így ejtik, nem igaz? Igaz? Thackeray? Így valahogy? Csak ekként ejtik!?”

Megragadta és egész valóját öklébe szorította. Nézte, ahogyan még kapálózott valamelyest, ügyetlenül vergődött, apró lábaival verdesett még a levegőben, gyermekien s szeretetre méltó módon maga elé mosolygott: „Hát igen, azt hiszem, hogy így ejtik. Igen. Jól ejti. Végül is, a th... Tha... Thackeray... Igen, ez az. Bizonyára ismerem a Vanity Fairt. Az az ő munkája.”

Kissé elfordította, hogy jobban lássa: - „Vanity Fair? Vanity Fair? Biztos benne? Vanity Fair? Ez tőle való?”

Folytatta, lágy remegéssel, még mindig a maga udvarias mosolyával, fürkésző várakozással. Míg egyre keményebb szorítóba fogták: „És merre megy? Douvres felé? Calais felé? Dover felé? Hm? Dover felé? Ugye? Dover?"

Nem volt mód a szabadulásra. Megállíthatatlan volt. Pedig a lány annyit olvasott... annyi gondolat járt a fejében... Az öregember pedig annyira elragadó lehetett volna... Ám épp rossz napja lévén fura kedvében volt. Folytatni fogja, könyörtelenül, lélegzetvételnyi szünet nélkül: „Dover, Dover, Dover? Igaz? Nem igaz? Thackeray? Igaz? Thackeray? Anglia? Dickens? Shakespeare? Hm? Hm? Dover? Shakespeare? Dover?" - eközben, bár az eröszak nélküli szabadulás lehetőségét latolgatta, mégsem mert nemtetszést kiváltó hirtelen mozdulatokat tenni, s mégis tisztelettudóan, fátyolos halk hangon válaszolt: „Igen, Dover, ez az. Bizonyára ön is gyakran megteszi ezt az utat... Úgy gondolom, kényelmesebb Douvres felé. Igen, ez az... Dover." 
Csak amikor már látta érkező szüleit, akkor tért kissé magához, engedte ki ökle szorítását, s kipirultan, összeborzolt hajjal, a lány is összegyürkösött csinos ruhájában mer végre, nem tartva többé az öregúr elégedetlenségétől, elmenekülni.

XVI.

Megöregedtek, elkoptak, ,akár az agyonhasznált agg bútordarabok, amelyek kiszolgálták idejüket és betöltötték feladatukat", és időnként (ez volt az ő duhajrohamuk), egyfajta beletörődéssel, megkönnyebbüléssel elegy, leginkább ropogásra hasonlító száraz sóhaj szakadt föl belölük.

A lágy tavaszi estékbe együtt mentek sétálni „most, hogy a fiatalságnak vége, amikor elmúltak a szenvedélyek”, elmentek nyugodtan andalogni, „szívni egy csepp friss levegőt, mielőtt lefeküdtek volna” vagy beülni egy kávézóba, eltöltve néhány percet, diskurálgatni.

Nem kevés elővigyázatosság után kiválasztottak egy védett sarkot („,ne ide: ez pont a huzatban van és ide sem: „csak ne a mosdó mellett”), leültek - „Ó, ropogó csontjaim, mindhiába, vénül az ember. Jaj! Jaj!” - és hallatszott kucorodásuk.

A helyiségben mocskos és hideg fény osont, a pincérek rémisztő, közönyös fejjel keresztbekasba suhantak, a poharak rideg üvege visszaverte a ráncosodó arcokat, a szapora pislogást.

Mégsem kérhettek ennél többet, ez az, sejtették, nem volt mit várni, nem volt mit kérni, így van ez rendjén, nincs semmi ezentúl, csak ez az „élet”.

Nincs semmi más, se semmi több, itt vagy ott, most már tudták.

Nem kell lázadozni, álmodni, várni, erőfeszítéseket tenni, elmenekülni; csak különös figyelemmel választani (a pincér vár türelmesen), hogy szörp legyen-e avagy kávé? tejszínese vagy sima? Szerényen befogadni az életet, - itt vagy akár ott - és hagyni, hogy teljen az idő.

\section{XVII.}

Amikor jóra fordult az idő, az ünnepnapokon, kimozdultak a külvárosi erdőkbe és hosszú sétákat tettek.

A sürü bozótosokat csomópont-szigetecskék szakították meg, amelyekben összefutottak az egyenes ösvények. A fü ritka volt és tarolt, ám az ágakon friss levélkezdemények jelentek meg; gyengék voltak még, hogy fényüket maguk köré szórják - azokhoz a savanykás 
mosolyra hajló gyermekekhez hasonlítottak, akik az érlelő napsugarakra összeráncolják szemöldöküket a kórházi szobákban.

Az ösvények mentén vagy a csupasz tisztásokon ültek le ebédjüket elkölteni. Mintha nem látnák, ami körülveszi öket, mégis mindez az ő felségterületük volna: a madarak cérnavékony kiáltása, a csámpásnak tetsző rügyfakadások, az összecsomósodott fügaz; mindennapjaik nehéz és sürü légköre itt is meglepte és elülte őket, akár a szívüket belengő fanyalgás.

Elhozták magukkal pihenőidejük társát, magányos gyermeküket.

Amint a csemete észlelte, hogy letelepedni indulnak egy közösen kiválasztott helyre, szétnyitotta kempingszékét, elhelyezkedett melléjük, majd lekuporodva rá, kapargatni kezdte a földet és a kavicsokat meg a leveleket gyüjtötte egy csomóba.

Beszélgetésük hangjai előbb elvegyültek az alaktalan iramodó árnyakat hozó csenevész tavasz aggodalomban rekedt illatával, mígnem egészen be nem borították mindenét.

Az ázott portól enyves levegő hozzátapadt, ráragadt a bőrére s a szemeire.

Nem volt hajlandó eltávolodni tőlük és elmenni játszani más gyermekekkel a rétre. Ott maradt, hozzájuk tapadva, és telve az örömtelenség mohóságával, magába szívta mindazt, amiről szó esett.

\section{XVIII.}

Londontól nem messze vagyunk, egy kartonfüggönyös falusi házikóban, hozzá benapozott, eső látogatta zöldellő kert.

A dolgozószoba lila akácokkal körülvett, üvegezett ajtaja erre a virító gyepre nyílik.

Egy macska ül egyenesen, csukott szemmel a felforrósodott kövön.

Fehér hajú, ibolyaszínben játszó rózsás arcú kisasszonyka olvas az ajtó előtt egy angol hetilapot.

Egészen mereven, méltóságának teljes tudatában ül ott, magabiztosan, és bízva embertársaiban meg szolidan gyökerező kis világegyetemében. Tudta, néhány perc múlva csengetni fognak: teához. 
A fehér viaszosvászonnal borított asztal előtt, lenn dolgozó konyhai személyzet, Ada zöldséget pucol. Arca mozdulatlan, olyan képe van, mintha nem gondolna semmire. Tudja, hogy hamarosan itt lesz az ideje, hogy megsüsse a „bunokat”, és hogy csengessen: teához.

XIX.

A fiú simaságát, redőtlen bőrü két ránctalan orcáját időről időre felajánlotta nekik, $\mathrm{s}$ ők megfeszült ajkaikkal rá ekkor csókot mértek.

Magukhoz vették és morzsolgatták, minden irányba forgatták, megtapogatták és lapogatták, ráhengeredtek. Aztán erre-arra pörgették, majd aggodalmaskodó, szelíd szemfényvesztő erőszakot vettek rajta, álajtókat és álablakokat nyitogattak előtte, ősbizalommal meglódult ezek felé, majd nekik ütődött, némi kárt téve magában.

Mindig is tudták, hogyan birtokolják egészen, anélkül, hogy körömnyi felüdülést hagytak volna a számára, lélegzetvételnyi menedéket, hogyan falják föl az utolsó porcikájáig. Porciózták, négyzetmilliméterekben osztozkodtak rajta, majd' minden irányban körbejárták; olykor futni is hagyták, engedtek a szorításon, de máris visszarántották, amint túlságosan is eltávolodott tőlük, hogy újból birtokukba vehessék. Kisgyermek kora óta ráérzett ennek a habzsolásnak az ízére - ellazult, beszívta fanyar édes parfümjük illatát, valósággal felkínálta magát.

Világukból, amelyben körbe vették s foglyul ejtették, nem volt menedék. Mindenünnen kíméletlen tisztánlátásuk vakító fénye hasította, amely mindent elegyengetett, magába szívta a nyúlt árnyakat éppúgy, mint az érdességet.

Már ismerték érintésük iránti kedvét, ezért egyáltalán nem zavartatták magukat.

Alaposan kiüresítették és kitömték rajongásukkal, ígérve neki mindenünnen más babákat, más arctalan alakokat. Nem menekülhetett elölük. Nem tehetett egyebet, mint hogy udvariasan odatartotta két gyönge orcáját, egyiket a másik után, hogy csókjuk pírja égesse.

XX.

Amikor kicsiny volt, éjszaka gyakran felriadt az ágyában és kitartóan hívta őket. A nők összeszaladtak, felkapcsolták a lámpákat, ujjaik közé vették a fehérnemüt, a törülközőt, a kezük markolta ruhákat, és mutogatták. Nem volt ott semmi. A fehérnemük a kezeik között védtelenné lágyultak, halottmerevvé zsugorodtak a pislákoló fényben. 
Most, hogy már nagyobbacska lett, még mindig hívja őket, hogy kukkantsanak be hozzá, keresgéljék csak, lássák jól és kezükkel is érintsék a benne meglapuló, zugait kitöltő félelmeket, s szemrevételezzék a napvilágnál.

Szokásukká vált, hogy belépnek és nagy gonddal körbe-körbe kutakodnak - azonmód elébük megy, maga világít nekik mindenütt, hogy ne érje hideglelésként homályban tapogatózó kezük érintése. Körbenéztek - mozdulatlan maradt, lélegezni sem mert -, ámde nem volt sehol semmi, ami félelmet ébreszthetett volna, majdnem minden a rendezettség benyomását keltette, helyénvalóan a régóta jól ismert berendezési tárgyakat ismerték föl és mutogatták is neki mindezt. Nem volt ott semmi. Mitől is félt volna? Néha, itt vagy ott, egy sötét zugban, valami mintha bizonytalanul rezzent volna, lágyan fogott reszketésbe, ám tenyerük egy határozott legyintésével alább hagyott a zizegés, semmi sem volt, csak az ő jól ismert félelemtüskéi - kirántották és mutatták is: a barátja lánya már férjhez ment? Vagy egy másik, aki mégiscsak vele egyívású, és mire vitte, milyen karriert futott be? Kitüntették? Ök elsimítanak, helyrehoznak mindent. Nem volt ott egy árva ijesztő lélek sem. Egy percre erősebbnek látta magát e felkarolt önbizalomban, ám máris érezte, ahogyan a tagjai elnehezültek s tehetetlenné váltak, beletompul ebbe a kimerevített várakozásba, és hirtelen, mint az ájulás előtti pillanatban, orrcimpáinak szúró sajgása volt tetten érhető; ekkor a nők szeme láttára egyszer csak visszahúzódik, felveszi gondolatűző arcrezdüléseit; úgyhogy a pofijára mért könnyed tompa ütések zaja mint holmi ráolvasás - a Windsorok, a Lebrun-ök utazása, az ötös ikrek - élesztette csak újra.

Ám miközben eszmélt és hagyták, hogy összeszedje magát, tiszta fejjel, szép rendben szoktatva magát az őt újra meglepő készültséghez, a félelem újra alakot öltött benne a kazetták és fiókok mélyén, amelyeket épp most nyitogattak és csukogattak végig, és mit sem találtak, újfent mindet kihúzogatva, majd betologatva.

XXI.

A fekete lüszter kötény, a mellkasáról hétről-hétre újra ragyogó apró keresztcsillogás jól és könnyen kezelhető kislánnyá tette, engedelmes és áldott gyermek volt: „Ez gyerekeknek való, néni?”, tette föl a kérdést, s pillantása kíváncsian a trafikost célozta, bizonytalankodva egy képes újság vagy könyv vásárlásakor.

Soha nem lett volna arra fogható, jaj, a világ minden kincséért sem, ebben a korban föleg nem, hogy csak úgy kislattyogjon az üzletből, hogy az árus szúrós tekintete a háta közepére 
szegeződve mustrálná minden porcikáját, pont amikor lenyomja a csengős kilincset s kilép, menekülvén a trafikos gyanakvó hunyorgása elöl.

Lám, milyen gyorsan megnőtt, nagyobbacska lett, sokat állt az esőn, hát igen, gyorsan repül az idő, ha már egyszer eltelt húsz esztendő, akkor kezdenek az évek egyre sebesebben szaladni, nem igaz? Szerintük is? A lány előttük találta magát fekete kosztümjében, mely mindenhez jól ment, aztán meg a fekete, mi igaz, igaz, mindig öltöztet... illendően, keresztbe tett karja színben elönyös kézitáskáján, ő pedig mosolygott maga elé, fejét lehajtva, szánakozón, hallott arról, már értesült róla, hogy a nagymamájuk agóniája mennyire elhúzódott, de hát ő mindig annyira erős volt, gondolhatják, ők még nem olyanok voltak, mint mi, a nagymamának még valamennyi saját foga megvolt, az ő korában... És Madeleine? A férje... Jaj, a férfiak, ha tudnának gyereket szülni, csak egy gyerekük lenne, magától értetődően nem fognának neki kétszer, az anyja, ez a szegény asszony, folyton ezt ismételgette. - Jaj! Jaj! Az apák, a fiak, az anyák! - A legidősebb lány lett nekik, ó mennyire szerettek volna előbb egy fiút, de nem, nem, még ráér; csak nem fog máris felállni, elmenni, megválni tőlük, itt marad, közel hozzájuk, egészen mellettük, a lehető legközelebb; a lány megértette, ez annyira kedves, egy öccse lett, megint csak lehajtotta a fejét, bizsergő mosoly fogta ajkait újra, ó, nem, ő véletlenül sem... nem, megnyugodhatnak, nem fog megmoccanni sem, ó nem, ő nem, soha nem tudná mindezt egyszeriben megtörni. Hallgatni; nézni őket; és pont a nagymama szenvedései alatt felugrani, óriási lyukat ütni, egérutat nyerni a megrepedt közfalon át és ordítva futni a házak között, amelyek kikucorodva leskelődnek a szürke utcák hosszán, mindegy, csak menekülni innen, átlépve a házmesternők kinyújtott lábait, akik hogy friss levegőn legyenek, kitárt ajtajuk küszöbén ülnek; csak futni, görcsbe rándult ajkakkal, loholni újfent, összefüggéstelen szavakat sisteregve, mígnem a házmesternők feltekintenek a kötésükből, férjük pedig térdére ereszti az újságját, szemük kivillan, a lány épp most fordul be az utcasarkon, a háta közepében gyilkos gyanakvás.

\section{XXII.}

Alkalomadtán, mikor nem látták, észrevétlen megkísérelt maga körül valami élettel teli melegségre lelni - végighúzta az ujjait az ebédlőszekrény fadongáin... nem vennék észre, vagy ha mégis, akkor talán azt hihetnék, hogy mozdulata - akár egy ártalmatlan, ám bevett hóbort -, csupán azt célozza, hogy átírja a sorsot, lekopogja.

Ha a hátát pörkölte árgus szemük figyelmes pislogása, akkor, mint a gonosztevő a tréfás filmekben, aki maga mögött észleli a felügyelő tekintetét, még fesztelenül befejezi 
szándékolatlannak és önkéntelennek mímelt mozdulatát, úgy kezdett dobolni az ujjaival, hogy nyugalmat árasszon, a jobb keze három ujjával, háromszor hármat, csak hogy hatékony legyen a babonajáték. Mindez azért eshetett meg, mert egyre közelebbről követték, mióta rajtakapták, hogy a szobájában a Bibliát olvassa.

A tárgyak is rossz sejtelemmel viseltettek iránta, azóta, hogy gyermekként beléjük csimpaszkodott, valósággal rájuk tapadt, hogy felmelegítsék, s átjárja az élet; vonakodtak azzá válni, aminek ő készült látni őket, ,a gyermekkor költői emlékeivé”. Rendreutasították és megzabolázták őket, arcukat eltörölték, névtelen, jól kiképzett háziszolgákká lettek; belátták, mi a dolguk, s nem voltak hajlandóak többé őt válaszra sem méltatni, kétségtelenül féltek, hogy megválnak tőlük.

Eltekintve azonban e ritkán előforduló tétova mozdulattól, tényleg semmit nem engedett meg magának. Fokozatosan sikerült úrrá lennie őrült hóbortjain, sőt, most már még annál is kevesebb volt neki, mint amennyit normális esetben elviseltek; nem gyüjtötte még a postabélyegeket sem, noha ez az épelméjüek mindenki szeme láttára felvállalt szokása is lehetett volna. Soha meg nem állt mostantól az utca közepén, hogy elbambuljon - mint rég, sétakor, amikor a kísérő személyzet, gyerünk! uzsgyi, csak! húzta-vonta -, hanem folytatta útját, és nem tartotta fel a forgalmat; elhaladt az útjába eső tárgyak előtt, még a legcsábítóbbak, a leginkább élettel telítettek elött is, anélkül, hogy akár egyetlen cinkos pillantást vetett volna rájuk.

Mindent összevetve, még azok közül a barátai vagy rokonai közül is, akik bele lettek volna habarodva a pszichiátriába, közülük sem tehetett neki senki sem szemrehányást, hacsak nem az ártalmatlan, bár önerősítő, majd elmaradó hóbortjaiért vagy az imádott konformizmusáért s egyfajta aszténiára való enyhe hajlamáért.

Ám ők mindezt jól türték; mindez, ha jól megfontoljuk, kevéssé veszélyes, még kevésbé szemérmetlen.

Csupán időről időre, amikor már túlságosan kifáradt, tanácsukat szem előtt tartva engedélyezett magának egy-egy rövidke magányos utazást. És ottan naplemente körül sétára indult a hó alatt áhítatosan nyújtózó, szelíd bánattal teli utcákat bejárva, kezeivel végigsimította a házak fehér és piros kőtégláit, szinte a falhoz tapadva, oldalvást, tartva attól, hogy túlságosan is indiszkrét lesz, bekandított egy-egy kivilágított ablaküvegen a földszinti szobácskákba, ahol valaki az ablak elé élénken zöldellő szobanövényeket ültetett, 
cserépkosárba, porcelán csészealjakon, s ahol azok meleg valójukból kilépve egyfajta titokzatos buja burjánzásban nehezülnek el, mindenfelé küldve fénylő sugaruk - az őszámára is, bár ismeretlen volt és idegen -; vagy egy asztalsarok, egy tálalószekrény-ajtó, egy félárnyékból világló szék gyékényülőkéje beletörődhetett abba, hogy könyörületessége révén, neki, igen az ő számára, mivel türelmesen ott áll és vár, megidézze üde gyerekkorát.

\section{XXIII.}

Csúnyák voltak, laposak meg közhelyesek, minden egyéniség nélkül valók, túlzó módon is kiveszőben a divatból, amolyan frázisszerüek, ötlött az eszébe, már annyiszor olvasott leírva effélét, Balzacnál, Maupassantnál, a Bovarynéban, kliséket, másolmányokat, a másolat másolatát, vallotta be magának.

Szerette volna őket ellökni magától, megmarkolni a grabancukat és messzire vetni őket. Ám ők teljes lelki nyugalommal körbe ugrálták a lányt, bájosan, ám annál önérzetesebben bazsalyogtak; egész álló héten át végezték kötelességüket, senkire sem számíthattak, csak saját magukra, semmit nem kértek úgy, mint hogy alkalmanként láthassák; felvehessék újra az őket egymáshoz füző kapcsolat fonalát, érezzék, hogy még itt van, még mindig a helyén, a kötelék, amely hozzájuk szorította. Semmi másra nem vágytak, mint hogy kérdezgessék miképp ez természetes is volt, ahogy bárki tette volna is, amikor barátokat, rokonokat látogat -, érdeklődvén, mi jóban jár mostanában, s hogy az utóbbi időben olvasott-e eleget, ment-e gyakorta bulizni, megtekintette-e a jó filmeket, s valóban remek alkotásoknak találta-e őket... Nekik módfelett tetszett Michel Simon, Jouvet alakítása, annyit nevettek rajtuk, és oly csodálatos estéket töltöttek velük együtt...

És ami a kliséket illeti Balzacnál, Flaubert-nél, a Bovarynéban, jaj, igencsak volt fogalmuk róluk, ismerték, nem tartottak tőlük - megértően mosolyogtak a lányra, úgy tünt, biztosak magukban: a lány mellett van a helyük, úgy tűnt, tisztában vannak azzal, hányszor szedték ízekre, festették le, írták körül őket, hányszor szívták ki belőlük az utolsó csepp nedvességet is, míg el nem simult minden, s olyanok lettek, mint a tengeri áramlathoz simult kavics. Simaságuk miatt nem kezdhette ki őket. Biztonságban voltak.

Körbevették, feléje nyújtogatták a kezüket: „Michel Simon... Jouvet... Na, ugyebár meg kellett venni jó elöre a jegyeket, hogy lefoglaljuk a helyünket... Később aligha sikerült volna, vagy oly borsos áron, akár a zsöllyére vagy a földszinti páholyba kérik is el...” Mostan még 
szorosabbra vonták a köteléket, diszkrét gyöngéden, nem fájt, magukra hurkolták a vékonyka fonalat, majd nagyot húztak rajta...

S lassanként vajmi szelídség meg lágyság, az irántuk érzett bizalom, igenlésük szükséglete húzta-rántotta be közéjük a körbe a lányt. Mígnem kezét nyújtva, kiengedve (Ja, igen... Michel Simon... Jouvet...), akár egy bájos engedelmes gyermek, velük együtt indult forgásba.

Lám itt vagyunk újfent, végre mindnyájan egybegyültünk, jól nevelten és szófogadóan azt cselekedjük, amit a szüleink is helyeseltek volna, mindnyájan itt találjuk magunkat; tisztelettudóan harsogunk, zengünk a kórusban, akár a mintagyerekek, akiket mindig is jóra intő kar és aggódó meleg figyelem övezett, míg kegyes szomorú körtáncban lejtünk, izzadt mancsocskáinkat adva egymásnak.

\section{XXIV.}

Csak néhanapján mutatkoztak, meglapultak lakásaik mélyén, árnyas szobáik setét zugában leselkedve.

Megcsörrentették, majd visszahívták egymást, tudakozódtak, felfigyeltek minden apró jelre.

Néhányuk abban lelte örömét, hogy kivágta az újságcikket, amelyben valakinek az anyja napközbenre női szabót keresett.

Mindenre jól és aprólékosan emlékeztek, féltékenyen állva ört; jó erősen, kört formálva tartották egymást a kezüknél fogva s körülvették öt.

Félig elmosódott, homályosan kivehető arcvonásaik visszafogott közege kört vont körülötte.

És amikor látni vélték, amint szégyenlősen kúszik-mászik a földhöz tapadtan, hátha eliszkolhat körükböl, mélyebbre engedték összekulcsolt kézfejük és, mindnyájan egyszerre guggolva le köré, rámeresztették megszállott üres tekintetük és rávillantották könnyedén gyermeteg mosolyuk. 